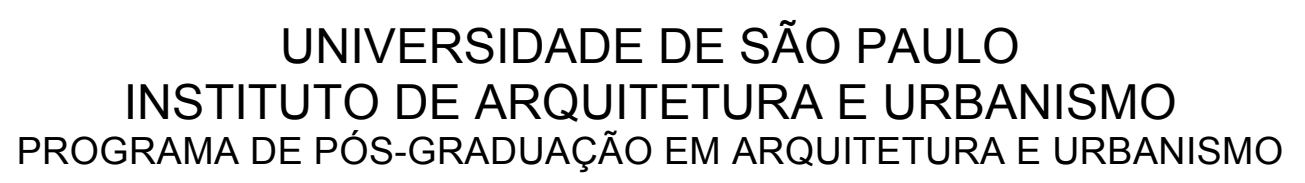

CAROLINA FERREIRA PINGO

Estudo sobre o uso de célula a combustível movida a bidrogênio solar em residências 
CAROLINA FERREIRA PINTO

\section{Estudo sobre o uso de célula a combustível movida a bidrogênio solar em residências}

Gese apresentada ao Instituto de Arquitetura e Urbanismo da Universidade de São Paulo, para obtenção do título de Doutor em Arquitetura e Urbanismo.

Área de concentração:

Arquitecura, Urbanismo e Gecnologia.

Orientador: Prof. Dr. Eduvaldo Paulo Sichieri 
AUTORIZO A REPRODUCÃO TOTAL OU PARCIAL DESTE TRABALHO, POR QUALQUER MEIO CONVENCIONAL OU ELETRÔNICO, PARA FINS DE ESTUDO E PESQUISA, DESDE QUE CITADA A FONTE.

Ferreira Pinto, Carolina

Estudos sobre o uso de células a combustível movidas a hidrogênio solar em projetos de arquitetura residencial / Carolina Ferreira Pinto; orientador Eduvaldo Sichieri. São Carlos, 2014.

Tese (Doutorado) - Programa de Pós-Graduação em Arquitetura e Urbanismo e Área de Concentração em Arquitetura, Urbanismo e Tecnologia -- Instituto de Arquitetura e Urbanismo da Universidade de São Paulo, 2014 .

1. Célula a combustível . 2. Hidrogênio solar . 3. Projeto de arquitetura. I. Título. 


\section{FOLHA DE JULGAMENTO}

Candidato: Arquiteto e Urbanista Carolina Ferreira Pinto

Título da tese: "Estudos sobre o uso de células a combustível movidas a hidrogênio solar em projetos de arquitetura residencial"

Data da defesa: 22/10/2014

Comissão Julgadora:

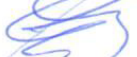

Prof. Tit. Eduvaldo Paulo Sichieri (Orientador) (Instituto de Arquitetura e Urbanismo - IAU/USP)

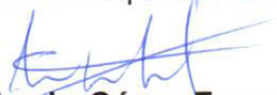

Dr. Antonio César Ferreira (UNITEC) - Itajobi

Prof. Assoc. Almir Sales

(Universidade Federal de São Carlos - UFSCar)

Profa. Assoc. Rosana Maria Caram

(Instituto de Arquitetura e Urbanismo - IAU/USP)

\section{Prof. Tit. Francisco Antonio Rocco Lahr}

(Escola de Engenharia de São Carlos - EESC/USP)

\section{Resultado:}
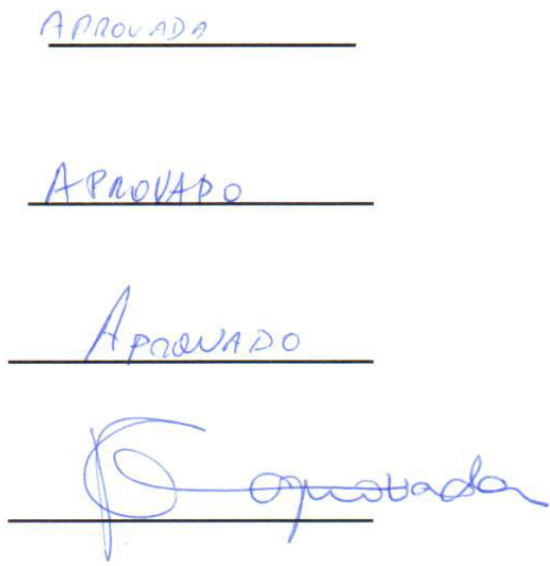

Qparavada

Coordenador e Presidente da Comissão de Pós-Graduação do Programa de PósGraduação em Arquitetura e Urbanismo: Prof. Assoc. Márcio Minto Fabrício 


\section{DEDICAGÓRIA}

À natureza, que nos fornece tudo.

Aos meus pais Marli e Acary, meu tio César e ao meu companheiro e amor Junior.

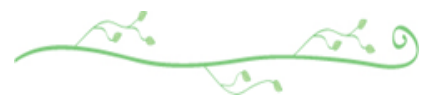




\section{AGRADECIOERGOS}

Manifesto minha gratidão à todos que me ajudaram. De forma particular, menciono:

O Professor Dr. Eduvaldo Paulo Schieri, que acreditou e viabilizou esta pesquisa.

Os membros da Banca Examinadora, pela disposição e contribuição.

A Capes, pelo fornecimento da Bolsa.

Os amigos que conheci durante o doutorado.

Os antigos amigos de vida André Sarria, Maristela Spigiorin e Lívia Spigiorin.

O meu tio César que me iluminou e confiou esse brilhante assunto.

Os meus pais, que torceram por mim desde o início, me incentivando a fazer o trabalho e não medindo esforços para me ajudar a realizar esta pesquisa.

A empresa UNITECH pelas informações e dados valiosos.

Em especial, o meu companheiro que me ajudou em todas as fases desta pesquisa, Gilberto Domingues Junior. 
"Acredito que a água será um dia usada como combustível, que o hidrogênio e o oxigênio que a constituem, usados juntos ou separados, fornecerão uma fonte inesgotável de calor e luz, com intensidade bem maior do que o carvão é capaz."

Júlio Verne

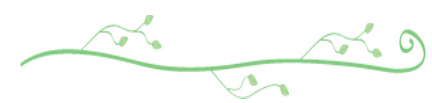





\title{
RESUCOO
}

\author{
Estudo sobre o uso de célula a combustível movida a hidrogênio solar \\ em residências. Tese (doutorado) - Instituto de Arquitetura e Urbanismo, \\ Universidade de São Paulo, São Carlos, 2014.
}

\begin{abstract}
Devido a crescente demanda de energia elétrica este trabalho tem como objetivo a elaboração de um projeto bioclimático de uma edificação para o estudo sobre o uso de célula a combustível movida a hidrogênio solar, como forma de energia alternativa. $O$ fornecimento de energia elétrica é feito apor meio de um sistema proveniente de painéis fotovoltaicos fornecendo energia para a produção de hidrogênio através da eletrólise da água para gerar energia elétrica com uma célula a combustível. A metodologia utilizada foi projetar uma casa típica da região do interior de São Paulo, para posteriormente dimensionar um sistema hidrogênio solar adequado para essa casa modelo. Foi feita a análise do clima local para posteriormente aplicar estratégias da arquitetura bioclimática. Os dados sobre o dimensionamento do sistema tais quais, número de painéis solares, número e volume dos tanques de hidrogênio necessários, potência e tamanho físico da célula a combustível foram fornecidos pela empresa UNITECH de fabricação de célula a combustível. Um modelo foi simulado utilizando uma planilha eletrônica; nele foram introduzidas as principais características e eficiências dos equipamentos que compõem o sistema, bem como o perfil de carga elétrica característico do local e seus custos. Como resultado foram analisadas as formas de dimensionar o sistema hidrogênio solar para uma residência típica, onde foi constatado que há duas formas de dimensionamento: uma através da demanda energética da casa $(\mathrm{kWh})$ e outra através da potência requerida pelos equipamentos da casa (Watts). O modelo escolhido a ser estudado e representado com o projeto arquitetônico foi pela curva da demanda energética diária resultando em 450 $\mathrm{kWh} / \mathrm{mês}$, havendo assim a diminuição da área de painéis solares e viabilizando a introdução da nova tecnologia. Outro cenário foi analisado pelo cálculo da potência, resultando em um total de $5 \mathrm{~kW}$ e obtendo uma extensa área de painéis solares, no entanto essa energia que sobra poderia ser fornecida para as concessionárias auxiliando nos horários de pico a energia consumida, ou ainda formando uma mini usina para comunidades isoladas. No projeto arquitetônico da edificação foram analisadas as mudanças e dificuldades quanto ao design, local e instalação dos componentes para implantação do sistema. Os dados de energia gerada e consumida são analisados servindo também como base para diversas pesquisas. Conclui-se que o sistema ainda não consegue ser competitivo economicamente com o sistema tradicional de energia elétrica, se não levado em conta aspectos ambientais, e sem o apoio de uma forte política governamental; porém aspectos do processo projetual arquitetônico se mantêm praticamente os mesmos. E ainda destaca-se a mudança de paradigma da energia elétrica, pois o consumidor passa a ser produtor.
\end{abstract}

PALAVRAS CHAVE: Célula a Combustível, Hidrogênio Solar, Residências. 


\section{ABSGRACG}

Study about the use of fuel cell powered solar hydrogen in homes. Thesis (doctor) Institute of Architecture and Urbanism, University of São Paulo, São Carlos , 2014 .

Due to increasing demand for electricity this paper aims to draw up a bioclimatic design a building for studies on the use of fuel cells powered solar hydrogen as an alternative energy. The electricity supply is done through a system from photovoltaic panels supplying power to produce hydrogen through electrolysis of water to generate electricity with a fuel cell. The methodology used was to design a typical home of the São Paulo region, using data from IBGE and SINFHA for later sizing a solar hydrogen system to the house style. Analysis of the local climate was taken by INMET, CPTEC and CIIAGRO. Subsequently the bioclimatic chart (NBR 15220) and the solar chart for use of bioclimatic architecture strategies are applied. The data on the system design as such, the number of solar panels, number and volume of hydrogen required, power and physical size of the fuel cell tanks were provided by the company UNITECH manufacturing fuel cell. A model was simulated using a spreadsheet; it was introduced the main characteristics and efficiencies of equipment that make up the system, as well as the listing of the characteristic electrical charge of the place and its costs. As a result ways to scale the solar hydrogen system for a typical residence, where it was found that there are two ways of scaling were analyzed: one through the house energy demand $(\mathrm{kWh})$ and the other through the power required by the equipment of the house (Watts). The model chosen to be studied and represented with the architectural design was by the curve of daily energy demand resulting in $450 \mathrm{kWh} /$ month, so there is a decrease in the area of solar panels and enabling the introduction of new technology. Another scenario was analyzed by calculating the power, resulting in a total of 5 $\mathrm{kW}$ and getting a large area of solar panels, however this left over energy could be provided for utilities assisting at peak energy consumed, or forming a mini plant for isolated communities. In the architectural design of the building, we analyzed the changes and difficulties regarding the design, location and installation of components for deployment. The data generated and consumed energy are analyzed also serving as base for numerous research. We conclude that the system still can not be economically competitive with traditional power system, if not taken into account environmental aspects, and without the support of a strong government policy; But aspects of the architectural design process remain largely the same.

KEYWORDS: Fuel Cell, Hydrogen Solar, Homes. 


\section{LISGA DE FIGURAS}

FIGURA 01 - Berço-maca da Unidade da rede Sarah no Rio de Janeiro .08

FIGURA 02 - Diagrama solar na versão informatizada. 20

FIGURA 03 - Zoneamento bioclimático brasileiro .23

FIGURA 04 - Zona bioclimática 6 e carta bioclimática para a respectiva zona........25

FIGURA 05 - Brise do Instituto do (Dundo Árabe, fechado e aberto 34

FIGURA 06 - Bairro Invasão dos Padres inundado para instalação da

bidrelétrica Belo Donte 64

FIGURA 07 - Área inundada para instalação da bidrelétrica Belo Donte. .64

FIGURA 08 - Atlas Brasileiro de Energia Solar demonstrando a média anual do tozal diário da irradiação solar. .74

FIGURA 09 - Constituição básica do sistema fotovoltaico isolado 81

FIGURA 10 - Constituição básica do sistema fotovoltaico conectado a rede. 81

FIGURA 11 - Elecrólise da água 88

FIGURA 12 - Eletrolisador do tipo filtro prensa modelo $\bigvee_{2}$ IGEn $^{\circledR}$. .89

FIGURA 13 - Principais componentes de um Eletrolisador. 89

FIGURA 14 - Ganques de bidrogênio para residência de nova Jersey. .93

FIGURA 15 - Cores de cilindros para os gases mais comuns. 108

FIGURA 16 - Locação de cilindros com gases 109

FIGURA 17 - Classificação e rozulagem de perigo 110

FIGURA 18 - Funcionamento de uma Célula a Combustível. 112

FIGURA 19 - Partes de uma célula a combustível. 113

FIGURA 20 - Célula do hospital Erasto Gaertner. 117

FIGURA 21 - célula da COPEL.. 117

FIGURA 22 - Célula da LACGEC 117

FIGURA 23 - Ônibus à hidrogênio 118 
FIGURA 24 - Esquema de funcionamento do sistema Solar-hidrogênio .136

FIGURA 25 - Funcionamento do sistema em uma casa conectada à rede elétrica convencional .136

FIGURA 26 - ПEXĞৃOUSE . .141

FIGURA 27 - Fachada da Solar-hydrogen home. .141

FIGURA 28 - Solar-hydrogen home durante o inverno .142

FIGURA 29 - Elecrolisador e painéis solares .143

FIGURA 30 - Ganques de hidrogênio .143

FIGURA 31 - Mapa da região de São José do Rio Preto .162

FIGURA 32 - Classificação Climática de Koppen no Estado de São Paulo .163

FIGURA 33 - Vista aérea da cidade de Cajobi. .164

FIGURA 34 - vista panorâmica de Cajobi .164

FIGURA 35 - Vista da região de estudo. .165

FIGURA 36 - Projeção do local no sofæware autocad...............................................................165

FIGURA 37 - Planta do loteamento Ecoville em Cajobi...........................................................166

FIGURA 38 - (Dapa das zonas bioclimáticas brasileiras e lista com algumas

dessas cidades e suas respectivas zonas e estratégias de projeto .171

FIGURA 39 - Abertura para melhor iluminação e ventilação natural. .178

FIGURA 40 - Implantação da residência. .182

FIGURA 41 - Planta da residência .183

FIGURA 42 - Planza de cobercura da residência. .184

FIGURA 43 - Corre A da residência. .185

FIGURA 44 - Corre B da residência................................................................................................186

FIGURA 45 - Fachada leste da residência ...............................................................................187

FIGURA 46 - Fachada norte da residência .....................................................................................188

FIGURA 47 - Fachada oeste da residência.................................................................................189

FIGURA 48 - Fachada sul da residência.........................................................................190

FIGURA 49 - Perspectiva fachada norte. ..........................................................................................191

FIGURA 50 - Perspectiva fachada oeste …….................................................................................191 
FIGURA 51 - Perspectiva fachada sul. 192

FIGURA 52 - Perspectiva fachada leste (principal) 192

FIGURA 53 - Sistema hidrogênio solar com gerador de células a combustível interligado a rede.

FIGURA 54 - KD2456̨-4FB - Códulo fotovoltaico multi-cristalino de alta eficiência. 195

FIGURA 55 - Eletrolisador PECD da marca ந̊GEn Proton Energy 195

FIGURA 56 - Representação esquemática do processo da eletrolise do tipo PECD.196 FIGURA 57 - Célula a combustível de $5 \mathrm{~kW}$ 199

FIGURA 58 - software de controle para sistema de célula a combustível 201

FIGURA 59 - Planta da residência. 204

FIGURA 60 - Casa de gás GLP. 205

FIGURA 61 - Perspectiva da residência. .206

FIGURA 62 - Perspectiva da casa de maquinas 207

FIGURA 63 - Vista de cima da casa de máquinas 207

FIGURA 64 - Vista da casa de máquinas com as ligações entre os componentes do sistema 208

FIGURA 65 - Curva de carga diária média no Brasil 209

FIGURA 66 - Gelhas Fozovolzaicas.

FIGURA 67 - Estoque de vinte e sete cilindros de bidrogênio, para uma célula de $3 \mathrm{~kW}$ 225

FIGURA 68 - Área ocupada por painéis solares para uma célula de pozencia de $3 \mathrm{~kW}$ 


\section{LISGA DE GABELAS}

GABELA 01 - Faixas de consumo de energia elétrica, SIDPদ̆A (2005 153

GABELA 02 - Resumo das principais características dos modelos e respectivas significâncias no setor residencial. 155

GABELA 03 - Saturação de equipamentos e serviços em domicílios particulares permanentes 157

GABELA 04 - Posses de equipamentos eletrodomésticos em domicílios brasileiros 158 


\section{LISGA DE QUADROS}

QUAADRO 01 - Iluminância para cada grupo de tarefas visuais .22

QUAADRO 02 - Critério e nível de desempenho de paredes externas quanto à

transmitância térmica.

QUAADRO 03 - Critério e nível de desempenho de paredes externas quanto à

capacidade térmica

QUADRO 04 - Critério de coberturas quanto à transmitancia térmica

QUAADRO 05 - Exemplos de diagnóstico de microclima em função da influência

da umidade .37

QUADRO 06 - Consumo mundial de energia por fonte. .51

QUAADRO 07 - Características de módulos fotovoltaicos de diferentes

tecnologias e dimensões. .79

QUAADRO 08 - Capacidade instalada de sistema fotovoltaico e potencial solar na

Alemanha, Espanha e Brasil (*sistemas conectados à rede) .84

QUADRO 09 - Características dos eletrolisadores disponíveis no mercado

(NREL, 2008)

QUADRO 10 - Classificação de gases. . .100

QUADRO 11 - Cores de cilindros para os gases mais comuns. . .107

QUAADRO 12 - Partes de uma célula a combustível .115

QUADRO 13 Financiamentos em pesquisas em CaC e நidrogênio .123

QUADDRO 14 - Características finais da residência modelo. .149

QUAADRO 15 - Relação dos bens de consumo, tempo de uso, potência e consumo da residência modelo .150

QUADRO 16 - Componentes utilizados no sistema de 5kW. .151

QUAADRO 17 - Características finais da residência modelo .156

QUAADRO 18 - Relação dos bens de consumo, tempo de uso, potência e consumo da residência modelo 
QUANDO 19 - Gemperađura e precipitações de Cajobi. 167

QUADRO 20 - Radiação Dédia Diária para as localidades próximas de Cajobi........168

QUAADO 21 - Dados climáticos para cidade de Pindorama................................................168

QUADRO 22 - Gemperatura e precipitações de Cajobi ..........................................................169

QUADRO 23 - Aberturas para ventilação e sombreamento das aberturas para zona 6 171

QUAARO 24 - Gipos de vedações externas para zona 6 171

QUADRO 25 - Estratégias de condicionamento térmico passivo para zona

bioclimatica 6 172

QUADRO 26 - Tipologias das aberturas. 177

QUADRO 27 - Gipos de materiais utilizados 177

QUADRO 28 - Componentes utilizados no sistema de 5kW 202 


\section{LISGA DE GRÁFICOS}

GRÁFICO 01 - Divisão do consumo de energia......................................................................4

GRÁFICO 02 - Uso Residencial da Energia Elétrica ...........................................................4

GRÁFICO 03 - Oferta mundial de energia por fonte …..................................................... 51

GRÁFICO 04 - Oferta da energia por fontes no Brasil.......................................................53

GRÁFICO 05 - Oferta de energias renováveis no Brasil em 2010 .................................54

GRÁFICO 06 - Estrutura da oferta interna de energia elétrica de acordo com a fonte de geração no Brasil....................................................................................54

GRÁFICO 07 - Participação por tecnologia fotovoltaica em 2007 (adaptado).....78

GRÁFICO 08 - Distribuição dos domicílios por região geográfica em 2010 ..........154

GRÁFICO 09 - Análise de Sensibilidade do Aumento da Demanda (kWh) no Custo de Implantação do Sistema e no Custo do kWh para uma Célula $5 \mathrm{~kW}$

GRÁFICO 10 - Análise de Sensibilidade do Aumento da Demanda (kWh) no Custo de Implantação do Sistema e no Custo do kWh para uma Célula $3 \mathrm{~kW}$

GRÁFICO 11 - Análise de Sensibilidade do Aumento da Demanda (kWh) no Custo de Implantação do Sistema e no Custo do kWh para uma Célula 10 $\mathrm{kW}$

GRÁFICO 12 - Análise de Sensibilidade do Aumento da Demanda (kWh) no Custo de Implantação do Sistema e no Custo do kWh para uma Célula 15 kW215

GRÁFICO 13 - Custo Anual Equivalente dos Componentes do Sistema (R\$) pela Demanda para uma Célula de $3 \mathrm{~kW}$ 217

GRÁFICO 14 - Custo Anual Equivalente dos Componentes do Sistema (R\$) pela Demanda para uma Célula de $5 \mathrm{~kW}$ 218 
GRÁFICO 15 - Custo Anual Equivalente dos Componentes do Sistema (R\$) pela Demanda para uma Célula de $10 \mathrm{~kW}$. 219

GRÁFICO 16 - Custo Anual Gquivalente dos Componentes do Sistema (R\$) pela Demanda para uma Célula de $15 \mathrm{~kW}$ 219

GRÁFICO 17 - Custo Anual Equivalente dos Componentes do Sistema (R\$) pela Potência (kW) da Célula 221

GRÁFICO 18 - Custo do kWh dos Componentes do Sistema (R\$) pela Potência $(\mathrm{kW})$ da Célula 221

GRÁFICO 19 - Produção de energia total do sistema por mês pela potencia da célula

GRÁFICO 20 - Múmero de cilindros de hidrogênio pela demanda mensal em kWh223

GRÁFICO 21 - Múmero de cilindros de bidrogênio pela potência. 224

GRÁFICO 22 - Área ocupada pelos painéis solares 226

GRÁFICYO 23 - Análise de Sensibilidade do Aumento da Demanda (kWh) no Custo do kWh e na Área ocupada pelos painéis solares para uma Célula $3 \mathrm{~kW}$ 228

GRÁFICO 24 - Análise de Sensibilidade do Aumento da Demanda (kWh) no Custo do kWh e na Área ocupada pelos painéis solares para uma Célula $5 \mathrm{~kW}$ 228

GRÁFICO 25 - Análise de Sensibilidade do Aumento da Demanda (kWh) no Custo do kWh e na Área ocupada pelos painéis solares para uma Célula $10 \mathrm{~kW}$.

GRÁFICO 26 - Análise de Sensibilidade do Aumento da Demanda (kWh) no Custo do kWh e na Área ocupada pelos painéis solares para uma Célula $15 \mathrm{~kW}$.

GRÁFICO 27 - Análise de Sensibilidade do Aumento da Demanda (kWh) no Custo de Implantação do Sistema e no Custo do kWh para uma 
Célula 40 kW em

uma Comunidade. .

232 


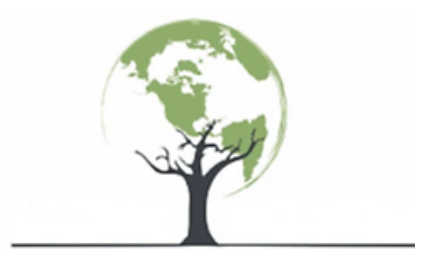

\section{SUCÁRIO}

RESUCO

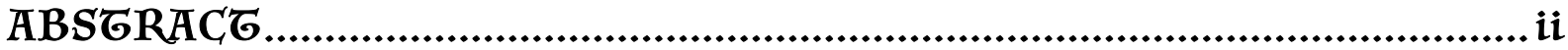

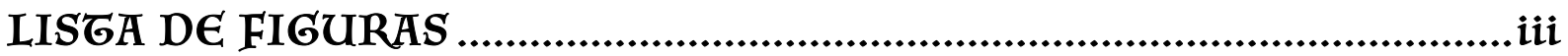

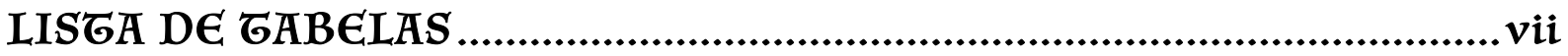

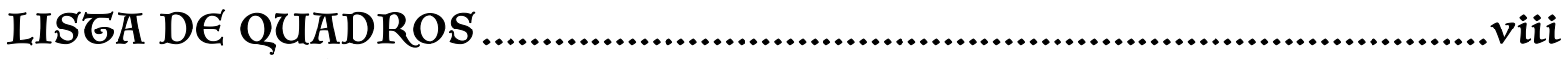

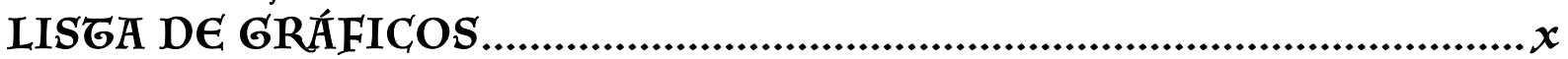

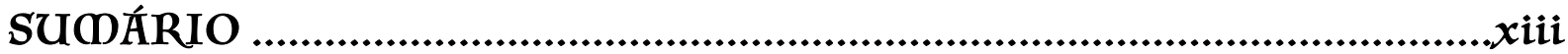

1. InGRODUÇत̃

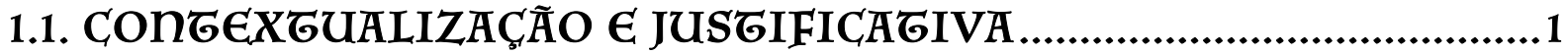

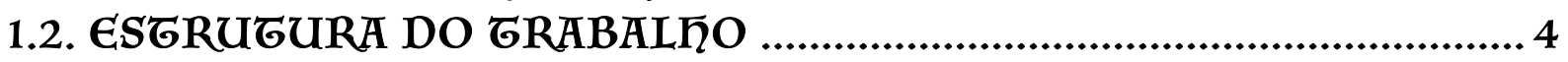

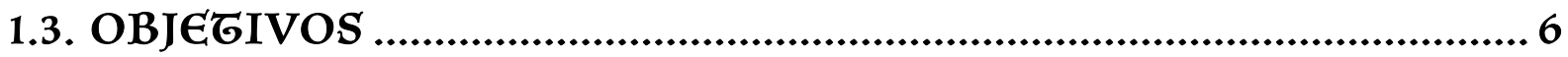

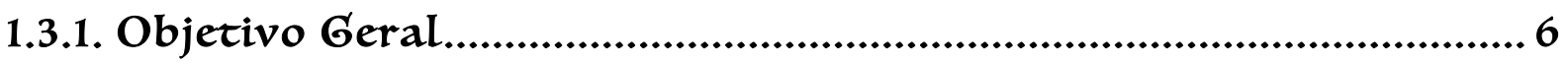

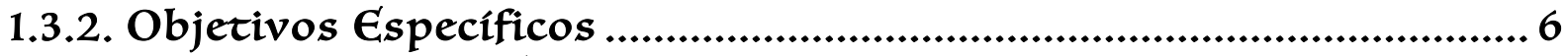

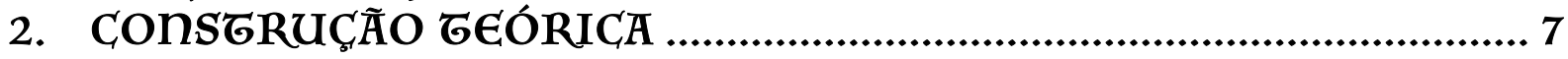

2.1. CONFORGO ADBIENGAL G ARQUIG GGURA ................................ 7

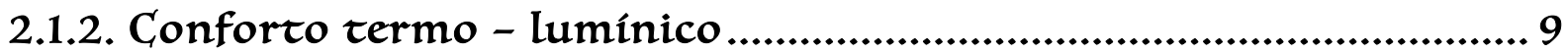

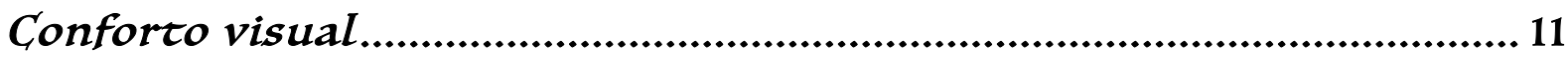

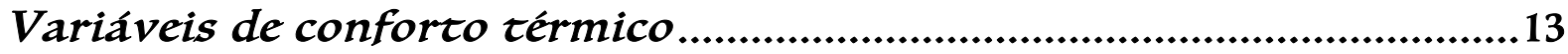

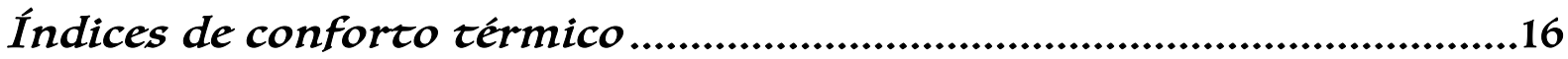

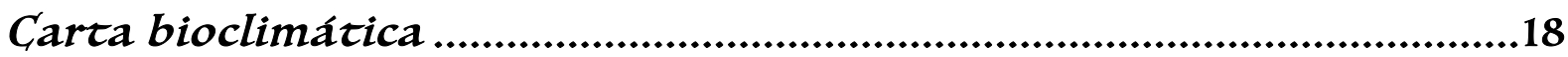

Diagrama solar ou Carta solar .....................................................................19

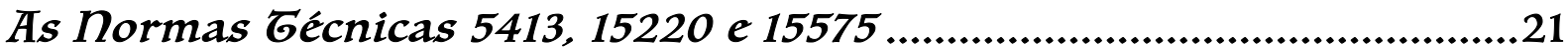

2.2. EFICIÊnCIA ENERGÉGICA G ARQUIGGGURA .............................29

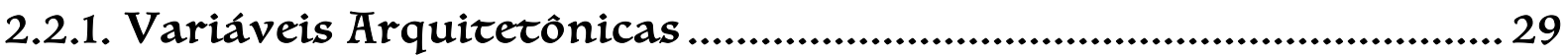

2.2.2. O Envelope: Fechamentos Opacos e Granslúcidos ........................ 32

2.2.3. Implantação e Orientação Solar .................................................34

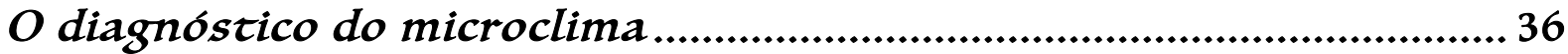

2.2.4. Sistemas de Climatização Predial ..............................................38

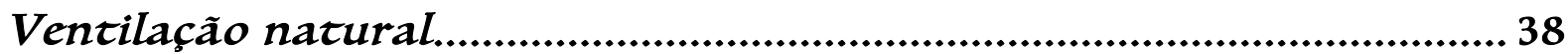

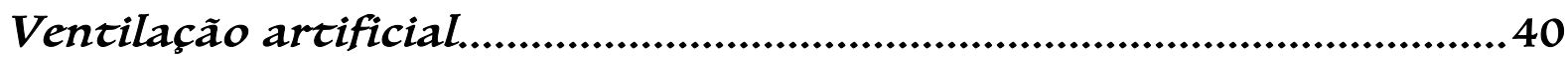

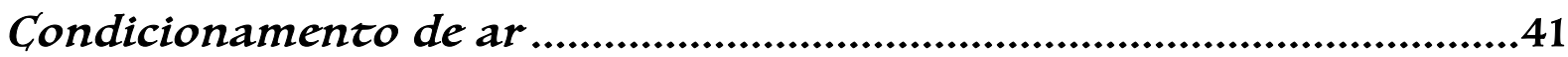

2.2.5. Sistemas de Iluminação Predial............................................................ 43 


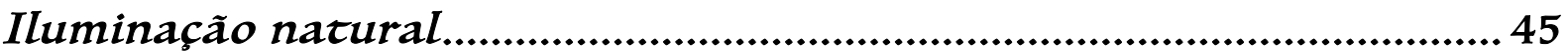

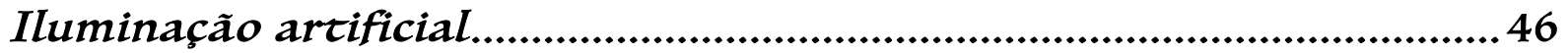

2.3. ENERGIA ELÉGRICA ED EDIFICAÇÕ ES ......................................49

2.3.1. Energia e Dundo ..................................................................................49

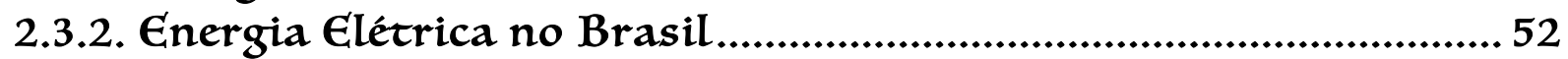

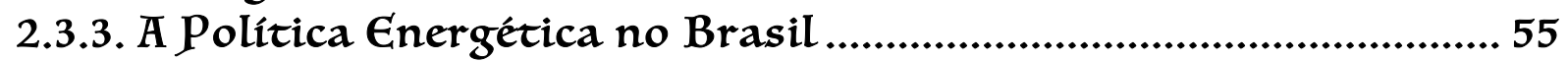

As políticas energéticas recentes no Brasil .............................................56

2.3.4. Conceitos de Energia Distribuída - Autonomia Energética em

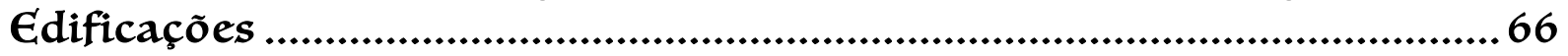

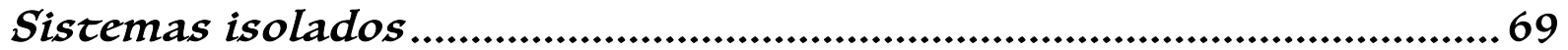

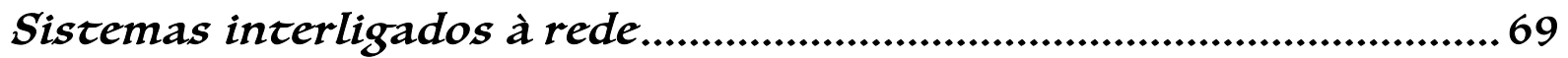

Comunidades isoladas e o acesso à energia elétrica................................ 70

2.4. ENERGIA SOLAR FOGOVOLGAICA ............................................72

Disponibilidade de irradiação solar no Brasil...................................... 73

2.4.1. Células Solares Fotovoltaicas - Gecnologias.............................. 75

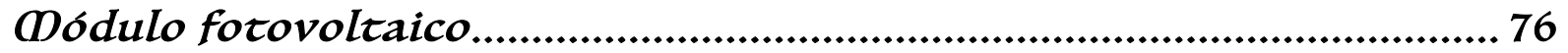

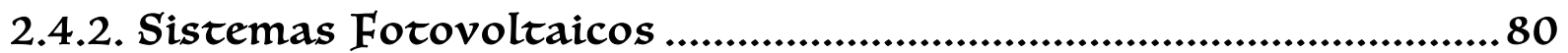

2.4.3. Sistemas Fotovoltaicos Conectados á Rede no Brasil ................84

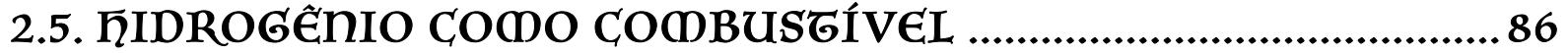

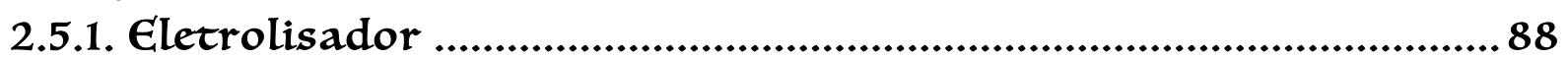

2.5.2. Wétodos de Armazenamento do நidrogênio ................................ 92

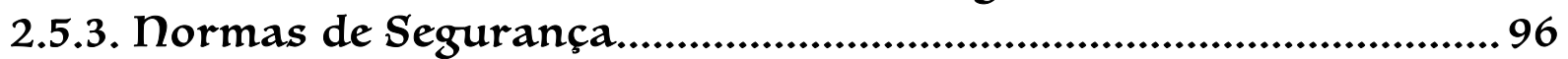

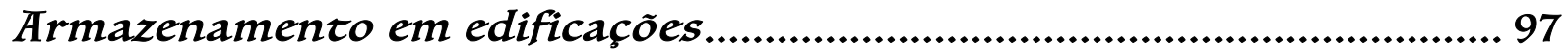

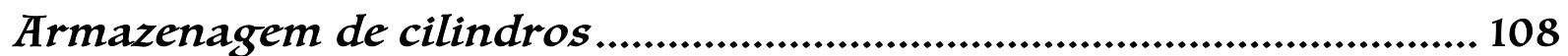

2.6. CÉLULAS A COMBUSGÍVEI ........................................................110

2.6.1. Funcionamento da Célula a Combustível ......................................111

Partes de uma célula à combustível (do tipo PEQ) .............................112

As células a combustível no Brasil........................................................115

As políticas internacionais e nacionais em relação às células a

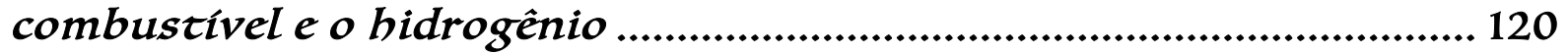

2.7. O SISGECA SOLAR - hIDROGÊnIO - CÉLULA A COMBUSGÍVEL 135

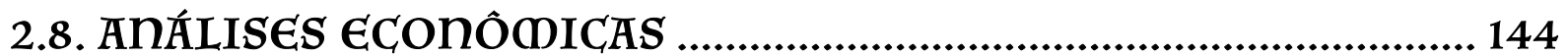

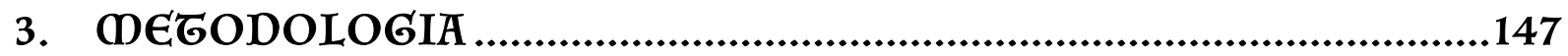

3.1. CARACGERÍSGICAS DA RESIDÊnCIA DODELO......................... 149

3.2. CARACGERÍSGICAS DO CONSUDO ENERGÉGICO DA CASA ... 149

3.3. CARAC'GERÍSGICAS DOS COMPONENGES UGILIZADOS NO

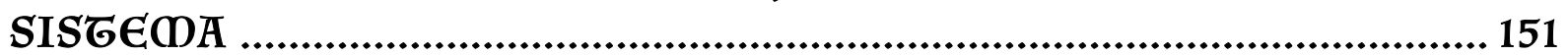

4. APRESEnGAÇন̃O E ANÁLISE DOS RESULGADOS..........................152

4.1. DEFInIÇÃO DO DODEIO RESIDENCIAL GÉRREO

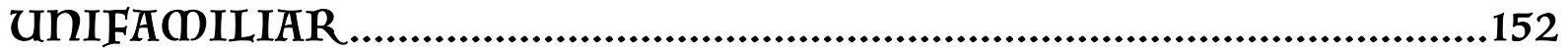

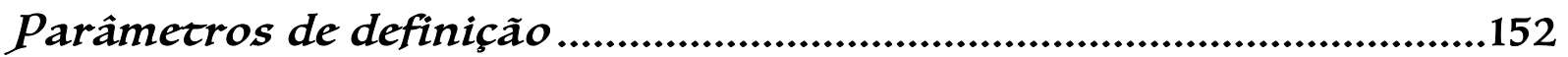

Caracterização da residência .............................................................154 


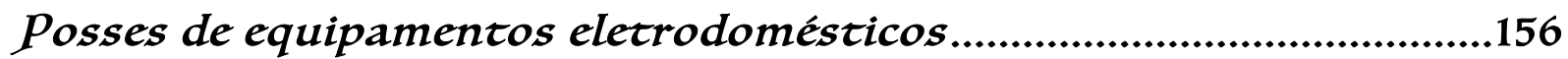

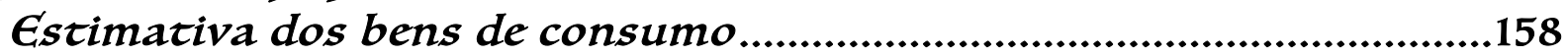

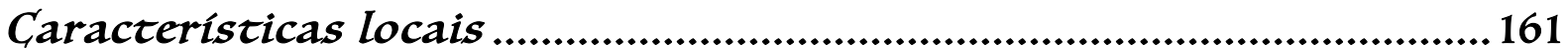

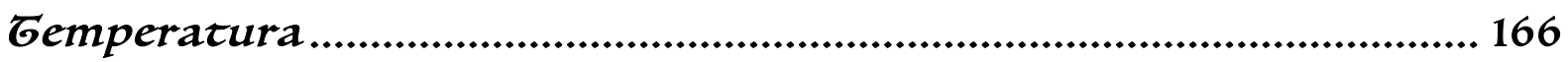

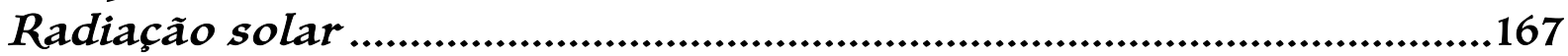

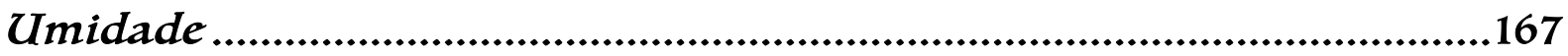

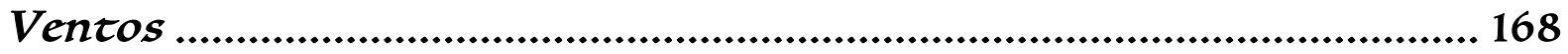

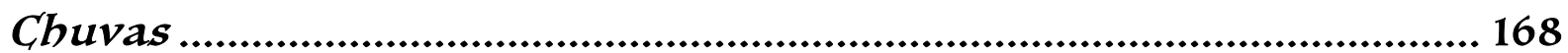

Aplicação da Carta bioclimática (nRB 15220).................................... 169

4.1.2. Descrição do modelo residencial ..............................................171

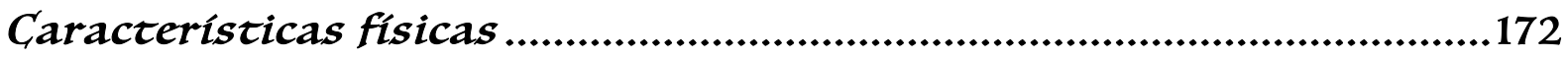

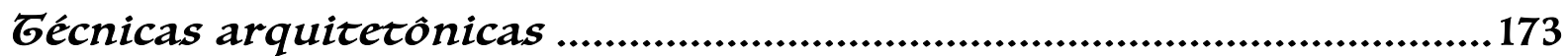

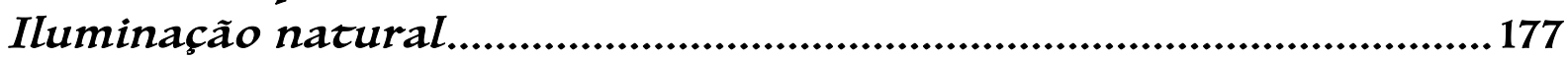

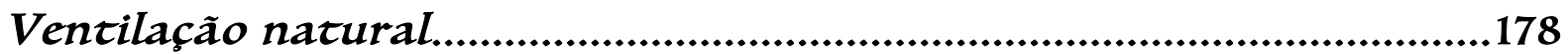

Implantação, planta, cortes e fachadas ...............................................179

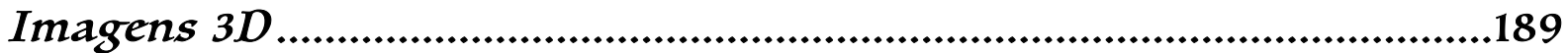

4.2. DIOENSIONAMENGO DO SISGECA দIDROGÊHIO SOLAR.... 191

4.3. ANÁLISE DO PROCESSO PROJEGUAL UGILIZANDO O SISGECA DE CÉLULA A COMBUSGÍVEL WOVIDA A দIDROGÊnIO SOLAR. 201 4.4. ANÁLISE DE SENSIBILIDADE DO AUCENGO DA DECANDA

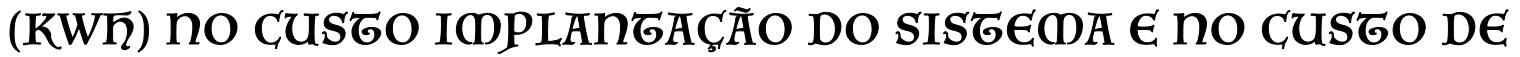
KWh ED RELAÇÃO À POGẾnCIA DA CÉLULA................................... 210 4.5. CUSGO ANUAL EQUIVALENGE DOS COMPONEnGES DO

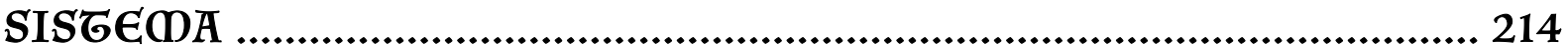

4.6. ESGUDOS $\epsilon$ COMPARAÇÕ $E S$ NA AROAZENAGEC DE

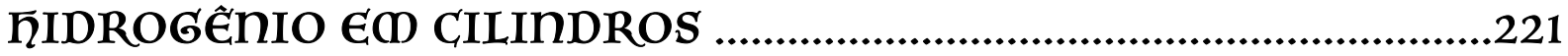

4.7. ESGUDOS E COMPARAÇÕES NA ÁREA OCUPADA PELOS PAInÉIS FOGOVOLGAICOS .............................................................224 Análise de Sensibilidade do Aumento da Demanda (kWh) no Custo do $k W h$ e na Area Ocupada pelos Painéis solares......................................... 225 4.8. ESGUDOS E COOPPARAÇÕES EO UOA COOUNIDADE DE 40 CASAS. 228

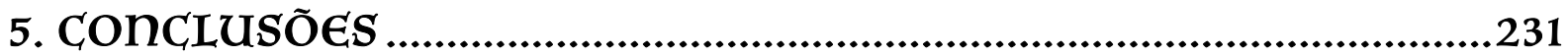

5.1. SUGESGÕES PARA GRABALদOS FUGUROS..............................2234

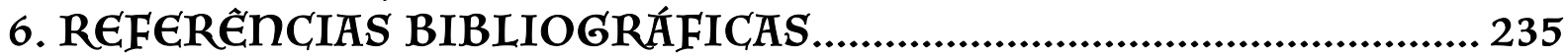

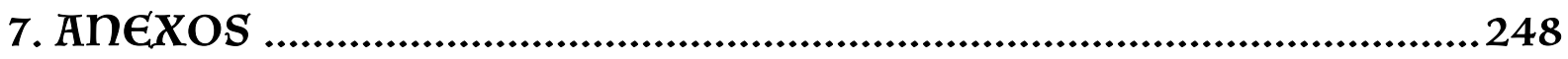





\section{InGRODUÇत̃̃}

\subsection{CONGEXGUALIZAÇÃO G JUSGIFICAGIVA}

A crise energética que surgiu no país no ano 2001 e o constante aumento da demanda de energia elétrica fizeram com que os projetos de arquitetura e engenharia tivessem uma maior preocupação na qualidade do ambiente construído quanto ao conforto, a eficiência e autonomia energética, e ainda com a possibilidade de geração de energia através de fontes renováveis não convencionais como parte integral da edificação.

Em uma cultura onde o homem está tradicionalmente em luta contra a natureza para conseguir meios de subsistência e outros recursos que possa aproveitar, é lógico que a arquitetura, qualquer que seja sua expressão tradicional ou moderna, torna-se uma fortaleza que o faz capaz de resistir às agressões exteriores, principalmente climáticas. Nestas condições o homem adequa-se ao clima e descobre que existe uma forma de interação com o processo de concepção arquitetônica, que é de integrar e adequar os princípios físicos de transferência de calor e as necessidades de caráter ambiental dos diversos tipos de usuários e de atividades.

Receber luz sem receber calor, ter aberturas para ventilação sem adição de calor, são alguns dos benefícios conseguidos para climas quentes e úmidos, tomando um conjunto de regras ou medidas de caráter geral, que influenciam a forma da construção, mas que não pretendem impor ou considerar como um tipo de construção. Estas estratégias são selecionadas tendo em conta a especificidade climática do local, função do edifício e consequente modo de ocupação e operação do mesmo. Assim se obtém uma edificação com altos níveis de conforto, funcionalidade e eficiência energética.

Entende-se que a eficiência energética num processo de conversão de energia é medida pela razão entre a energia útil requerida em um processo e a energia total fornecida a ele. Quanto maior essa relação, maior é a eficiência energética do processo. Aplicando este 
conceito, diz-se que uma edificação é energeticamente mais eficiente que outra, quando proporciona as mesmas condições de conforto com menor demanda de energia.

O aumento do consumo de energia elétrica implica obrigatoriamente no aumento da potência instalada de geração. Este aumento representa um custo elevado, tanto ambiental quanto em investimentos em equipamentos, se atendidos pelas fontes atuais de energia (FURLANETTO; POSSAMAI, 2001). Na arquitetura as medidas para reduzir a demanda de energia passaram a ser praticadas, pois o consumo de energia elétrica entre as edificações é relativamente alto (45\%) e destes, $22 \%$ destinados às residências (BEN, 2012).

De acordo com o Balanço Energético Nacional (2012) a demanda elétrica no Brasil está baseada em hidroelétricas (80\%) até então eficientes, mas com o "apagão" em 2001 e recentemente acontecendo (2012, 2013, 2014 em algumas cidades do país) ficou clara a necessidade de expansão do potencial elétrico instalado nacionalmente para atender a crescente demanda. Apesar de ser uma fonte limpa e renovável de energia, as hidroelétricas geram grandes impactos ambientais e sociais, têm alto custo e ainda existe a perda de energia nas extensas linhas de transmissão.

Dentre as opções de alternativas energéticas limpas e renováveis, tem-se a energia solar e eólica, pois o potencial dessas energias primárias no Brasil é grande (RUTHER, 2004), porém a energia eólica só ocorre nos momentos em que há velocidade do vento suficiente, e tem a desvantagem de normalmente necessitar grandes áreas livres de terra para instalação das turbinas.

A energia fotovoltaica não polui durante seu uso, as centrais necessitam de manutenção mínima, os painéis solares estão cada dia mais potentes e seu custo vem diminuindo, é ideal em lugares remotos ou de difícil acesso, pois sua instalação em pequena escala não obriga a ter investimentos em linhas de transmissão. No entanto o rendimento da tecnologia é baixo (em torno de 15\%), além do que durante a noite (onde há o pico de consumo energético residencial) não existe produção alguma, o que obriga que existam meios de armazenamento da energia produzida durante o dia em locais onde os painéis solares não estejam ligados à rede de 
transmissão de energia (RUTHER, 2004). As formas de armazenamento da energia solar atualmente usadas são poluentes, pouco eficientes e têm vida útil curta, como as baterias convencionais do tipo chumbo ácidas, níquel cádmio e lítion íon.

Diante desse quadro negativo da estocagem da energia fotovoltaica aparece como solução uma promissora tecnologia de armazenamento de energia, o elemento químico mais abundante do mundo, o hidrogênio $\left(\mathrm{H}_{2}\right)$ (SILVA, 1991). Pode ser obtido pelas formas: eletrólise da água; por reforma de álcool e hidrocarbonetos (metanol, etanol, metano, gás natural e outros), etc. Assim, é considerado por muitos o "combustível ideal" (RIFKIN, 2003).

Quando o hidrogênio é combinado com uma célula de combustível (o motor do sistema) oferece uma produção de eletricidade silenciosa, de alta eficácia e limpa, formando apenas como produtos da reação a água e o calor, não havendo quaisquer emissões de partículas poluidoras. Existem vários tipos de células a combustível. As características delas se diferenciam na tecnologia dos materiais utilizados para sua formação, ou o combustível de abastecimento, ou na temperatura de funcionamento.

As mais utilizadas são: alcalina - AFC (Alkaline Fuel Cell) utiliza um eletrólito de solução alcalina; cerâmicas - SOFC (Solid oxide fuel cell) funcionam apenas com temperaturas altas entre os $600^{\circ} \mathrm{C}$ e os $1000^{\circ} \mathrm{C}$, e tem um sistema de funcionamento complexo; carbonato fundido - MCFC (Molten carbonate fuel cell) possui carbonato alcalino em uma matriz cerâmica tem um funcionamento complexo; ácido fosfórico - PAFC (Phosphoric acid fuel cell) comercialmente disponível, mas ainda necessita de temperaturas elevadas $\left(160^{\circ} \mathrm{C}\right.$ e $\left.220^{\circ} \mathrm{C}\right)$ e a membrana polimérica - PEMFC (Proton exchange membrane fuel cell) comercialmente disponível, tem funcionamento simples e não necessita de altas temperaturas (entre $80^{\circ} \mathrm{C}$ a $90^{\circ} \mathrm{C}$ ) (LINARD, 1999). No Brasil já existem fabricantes de células a combustível do tipo PEMFC e são as mais indicadas em estacionárias de pequeno porte (entre 1 a $10 \mathrm{~kW}$ de potência) (PINTO, 2009).

Sendo assim, o hidrogênio tem um grande potencial ambiental, fazendo parte de um ciclo de vida limpo, tornando-se um forte candidato a substituir a atual economia baseada nos 
combustíveis fósseis. Para que isto seja possível é necessária a resolução de problemas relativos à sua infraestrutura. É uma tecnologia nova, portanto o custo, o transporte e a distribuição do elemento como combustível estão em fase de amadurecimento.

Com base no exposto, o presente trabalho tem como principal objetivo o desenvolvimento de um projeto arquitetônico bioclimático de uma residência unifamiliar, que utiliza um sistema de energia limpa, renovável e distribuída. O hidrogênio solar é o combustível para uma célula a combustível do tipo PEMFC (Solar $-\mathrm{H}_{2}-\mathrm{CaC}$ ). Com o estudo do sistema é possível analisar as vantagens, as desvantagens, os custos, o modo como ficarão locados os equipamentos do sistema na residência, a importância da segurança na estocagens do hidrogênio entre outras.

\section{JUSGIFICĀGIVA}

Devido aos problemas contextualizados, uma das soluções seria diversificar a matriz energética através de fontes limpas e renováveis de energia, excluindo as extensas e dispendiosas linhas de transmissão. O trabalho elege a energia solar, pois o país tem radiação em abundância, no entanto é uma fonte intermitente de energia necessitando de uma eficaz sistema de armazenagem. O hidrogênio na forma de gás, estocado em cilindros pode desempenhar esse papel de maneira silenciosa e segura. O hidrogênio serve como combustível para um célula a combustível tipo PEM (pois opera em baixas temperaturas, ideal para sistemas estacionários de pequeno porte). O local escolhido para implantação do projeto e análises foi na de cidade de Cajobi, interior de estado de São Paulo, por possuir uma das quatro empresas de células a combustível existente no Brasil, e ser a cidade natal da autora. O trabalho servirá para o aprendizado da sociedade em geral, para empresas fabricantes de $\mathrm{CaC}$ e para o desenvolvimento da produção de $\mathrm{H} 2$, como também o amadurecimento e disseminação do tema e apara comunidade acadêmica da área de arquitetura, mostrando a utilização e funcionamento dessa nova tecnologia. 


\subsection{ESGRUGURA DO GRABALদ̆O}

O trabalho está dividido em sete capítulos, seguindo uma sequência adequada para o desenvolvimento do tema abordado.

No capítulo 2, onde se inicia a revisão bibliográfica, foram levantados conceitos sobre o conforto ambiental, nos assuntos que tangem a economia de energia, tal como, conforto térmico e lumínico; eficiência energética; energia distribuída, limpa e renovável; energia solar; hidrogênio e células a combustível. Foi feito um panorama da situação energética do país e do mundo, demonstrando dados atuais sobre o balanço energético, a matriz energética brasileira e mundial, e um breve histórico do sistema energético brasileiro e dado um enfoque maior nos assuntos sobre armazenamento do hidrogênio e nas células a combustível tipo PEM.

No capítulo 3 trata da metodologia aplicada para o desenvolvimento do projeto arquitetônico da edificação onde são levantados os dados do clima local, tipificação do modelo residencial e definição da curva de demanda elétrica da edificação para aplicação do dimensionamento do sistema de energia elétrica hidrogênio solar e suas características (metragem e marca do painel fotovoltaico, tamanho e marca do eletrolisador, armazenagem de hidrogênio e tamanho da potência da célula combustível).

No capítulo 4 são apresentados os resultados como a casa modelo projetada de acordo com as normas de conforto e o clima local e a aplicação do sistema dimensionado de acordo com as necessidades energéticas, seja da curva de demanda ( $\mathrm{kWh}$ ) ou da potência requerida (W). Nas discussões são levantados os pontos sobre a pouca mudança no processo projetual da casa para a implantação do sistema, calcula-se outras potências e demandas energéticas possíveis para uma residência com intuito de viabilizar os custos e ainda faz-se um cenário de 40 casas (representando uma comunidade isolada) para análise de custos.

No capítulo 5 são apresentadas as conclusões, no capítulo 6 a bibliografia utilizada e no 7 estão os anexos. 


\subsection{OBJEGIVOS}

\subsubsection{Objetivo Geral}

O presente trabalho tem como objetivo o estudo da utilização e demonstração da locação do sistema de células a combustível movidas a hidrogênio solar, e propõe uma metodologia de como dimensionar esse sistema para residências.

\subsubsection{Objetivos Específicos}

$>$ Projetar uma edificação bioclimática de acordo com o clima da cidade de Cajobi.

D Destacar a importância da adoção das estratégias de conforto térmico e lumínico para economia de energia elétrica visando melhoria da viabilidade do sistema hidrogênio solar. $>$ Dimensionar o sistema célula a combustível movido a hidrogênio solar para geração de energia distribuída em edificações de pequeno porte.

$>$ Verificar a melhor locação dos componentes do sistema Solar- $\mathrm{H}_{2}-\mathrm{CaC}$ para melhor segurança e conforto do usuário.

$>$ Analisar se há mudanças no processo projetual utilizando o sistema Solar $-\mathrm{H}_{2}-\mathrm{CaC}$.

$>$ Simular o custo do sistema hidrogênio solar de acordo dimensionamento feito pelo consumo de energia (kWh).

$>$ Simular o custo da produção de energia total disponibilizada pelo sistema em 24 horas de utilização.

$>$ Discutir as vantagens e desvantagens do sistema. 


\section{CONSGRUÇत̃̃O GEÓRICA}

\subsection{CONFORGO AOBIENGAL G ARQUIGEGURA}

O conforto do usuário através da arquitetura divide-se nos temas: térmico, lumínico, visual, acústico e ergonômico. Nesse trabalho se deu destaque naqueles que tem ligação direta com o consumo de energia, ou seja o conforto térmico e lumínico.

O enorme desenvolvimento tecnológico de materiais e equipamentos que possibilitou aos arquitetos ficarem livres para importar modelos, formas e materiais, criar à vontade, levou a um afastamento da arquitetura vernacular e a uma deterioração do conforto ambiental natural das edificações, ao mesmo tempo em que fomentou o uso excessivo de todo e qualquer recurso disponível.

Segundo ROMERO et al. (2001), técnicas passivas foram sendo descartadas dos conceitos arquitetônicos, negando os bons exemplos passados. Simultaneamente, meios artificiais de controle do ambiente, as técnicas ativas, pedem por avanços e atualizações, devido às pressões de mercado e ao estigma de "Edifício Inteligente".

O "Edifício Inteligente", ou seja, o edifício que possui um Sistema Integrado de Automação Predial trouxe à crescente sofisticação dos equipamentos de controle, climatização e iluminação artificial de grandes edificações, para otimizar sua operação e manutenção e sua eficiência energética. Mas representa apenas um ato paliativo para os problemas criados por este tipo de intervenção arquitetônica.

O conceito de Arquitetura Sustentável ou "Green Building" é o que possibilita empreendedores, arquitetos, projetistas, gerenciadores e outros profissionais envolvidos na área da construção civil a integrarem tópicos de eficiência de recursos, além de respeito ambiental e cultural aos projetos, criando edificações e comunidades que são mais lucrativas de construir (ou 
reformar), mais baratas para operar, mais saudáveis e confortáveis de ocupar, e mais produtivas para quem nelas trabalha. Para tanto é necessário que uma equipe multidisciplinar analise pontos como o terreno, as redondezas e a implantação, eficiência energética e de uso da água, eficiência de materiais de construção, projetos mecânicos e de iluminação.

Um excelente exemplo deste tipo de abordagem são os hospitais da Rede Sarah, projetados pelo arquiteto João Figueiras Lima, o "Lelé" (SÉRIE ARQUITETOS BRASILEIROS, 1999). Sua metodologia inicia um projeto reunindo uma equipe multidisciplinar, que conta com desde projetistas de elétrica e paisagistas até psicólogos especializados em hospitais. Pôde ser observado que os doentes necessitavam tomar certa quantidade de banho de sol todos os dias, que isto aceleraria sua recuperação. Foi então desenvolvido o primeiro desenho do projeto: a cama-maca. O resto do projeto foi todo concebido a partir deste equipamento. Tamanho de corredores, elevadores, rampas, enfermarias, etc., tudo para que o doente internado pudesse transitar pelo hospital deitado em sua cama-maca. A foto 01 mostra o berço-maca da unidade da Rede Sarah no Rio de Janeiro.

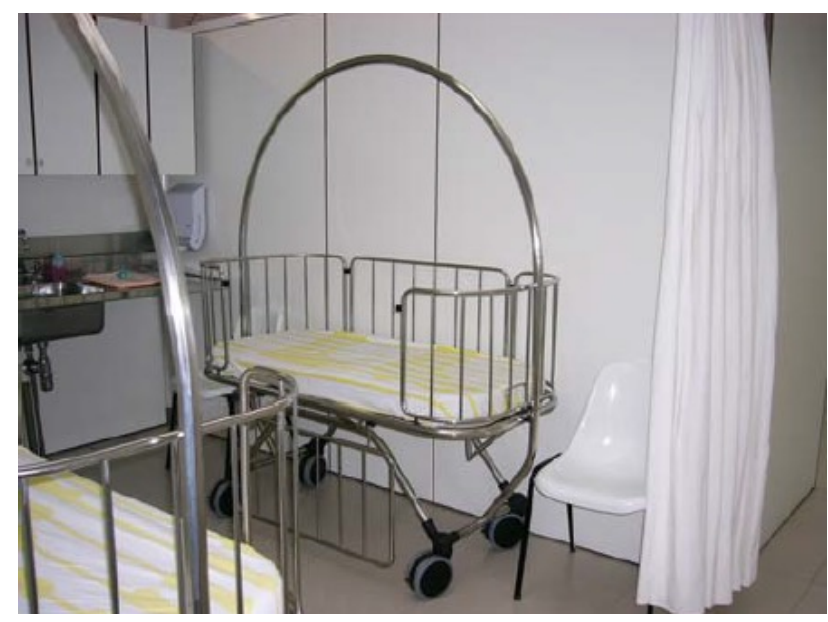

Figura 01: Berço-maca da Unidade da rede Sarah no Rio de Janeiro.

Fonte: Arquivo pessoal.

De acordo com MASCARÓ, L. (1991), a separação contumaz entre implantação e arquitetura, recursos naturais e projetos de formação mental típica do período da energia fácil, está hoje restrita, e obriga a se confrontar com as exigências dos princípios da Arquitetura 
Bioclimática, poupadoras de energia. Há toda uma gama de conhecimentos arrolados no tocante à utilização das variáveis climáticas no ato de projetar, visando a um maior conforto e à maior eficiência energética, inclusive a normatização. Existem atualmente vários softwares desenvolvidos especialmente para simulação e análise de ambientes e edificações, do ponto de vista do conforto térmico, lumínico e acústico, vários deles desenvolvidos em universidades brasileiras. CORBELLA e YANNAS (2003) descrevem brevemente vários deles, como o Analysis, Meteonorm, Weather Tool, Ecotect, Luz do Sol, Energy-10, Adeline, Radiance, Oida, etc. e a cada dia são disponibilizados, até gratuitamente, softwares e informações de conforto ambiental.

Respeitar a natureza não significa rejeitar o desenvolvimento, e sim adaptá-lo ao meio ambiente. Um projeto bem adaptado às condições locais, além de causar bem-estar às pessoas, reduz as necessidades de energia e aumenta a durabilidade da construção.

\subsubsection{Conforto termo - Lumínico}

O conceito de conforto neste trabalho está baseado no princípio de que quanto maior for o esforço de adaptação do indivíduo em um ambiente, maior será sua sensação de desconforto.

Segundo a ASHRAE Standard 55 (Norma 55 da Sociedade Americana dos Engenheiros de Aquecimento, Refrigeração e Ar-Condicionado) (American Society of Heating, Refrigerating and Air-Conditioning Engineers), o "Conforto Térmico" pode ser definido como:

"Um estado ou condição de sentir satisfação com relação ao ambiente térmico em que a pessoa se encontra. Se o resultado das trocas de calor a que o corpo da pessoa se encontra submetido for nulo, e a temperatura da pele e suor estiverem dentro alguns limites aceitáveis, é possível dizer que a pessoa sente Conforto Térmico." 
Existe também a definição de Olygay de 1973:

"A zona de conforto representa aquele ponto no qual a pessoa necessita de consumir a menor quantidade de energia para se adaptar ao ambiente circunstante".

Várias são as formas de definir conforto térmico. A escolha de um ou outro tipo de índice de conforto deve estar relacionada com as condições ambientais, com a atividade desenvolvida pelo indivíduo, pela maior ou menor importância de um ou de outro aspecto de conforto.

Há condições termo-higrométricas que podem, mesmo que apenas por algum tempo, ser consideradas como de conforto em termos de sensação, e provocar distúrbios fisiológicos ao fim desse tempo. É o caso, por exemplo, de indivíduos expostos a condições de baixo teor de umidade e que, não percebendo que estão transpirando porque o suor é evaporado rapidamente, não tomam liquido em quantidade suficiente e desidratam.

Em seus estudos realizados em câmaras climatizadas na Dinamarca, FANGER (1970) define conforto térmico como sendo, "uma condição da mente que expressa satisfação com o ambiente térmico". Essa se tornou uma definição clássica desde então, estando inclusive incluída em normas e manuais de conforto térmico como a ASHRAE 55-1992 (1992). Com uma visão crítica com relação ao caráter psicológico dessa definição, "...condição da mente...", ROHLES (1980), adverte que na maioria dos estudos de conforto térmico analisam-se conjuntamente a temperatura do corpo, "condição do corpo", e as sensações relatadas pelas pessoas, "condição da mente". Com essa advertência, o autor argumenta que os estudos convencionais não levam em conta apenas a condição da mente, mas também a condição do corpo de uma maneira bem mais acentuada.

Em outras palavras o Conforto térmico pode ser definido pela sensação de bem estar, relacionada à temperatura ambiente e umidade. Isto envolve equilibrar o calor produzido pelo corpo com o calor perdido para o meio ambiente circundante. 


\section{Conforto visual}

Do ponto de vista fisiológico, o indivíduo dispõe de sistemas de percepção da luz, do som e do calor, que apesar de complexos são compreensíveis. Para desenvolver determinadas atividades visuais, o olho necessita de condições específicas e que dependem dessas próprias atividades. Assim para ler e escrever necessita-se de certa quantidade de luz no plano de trabalho; para desenhar ou desenvolver atividades visuais de maior acuidade visual (atividades mais "finas" e com maior quantidade de menores detalhes), necessita-se de mais luz (PROCEL EDIFICA, 2011).

A quantidade de luz não e o único requisito necessário para essas atividades, a boa distribuição destes níveis pelo ambiente e a ausência de contrastes excessivos (como a incidência de sol direto no plano de trabalho e reflexos indesejáveis) também são fatores determinantes do conforto visual.

Quanto melhores forem as condições propiciadas pelo ambiente, menor será o esforço físico que o olho terá de fazer para se adaptar as condições ambientais e desenvolver bem a atividade em questão. O mesmo raciocínio pode ser usado para definir as condições de "maior ou menor esforço de adaptação" em relação ao sistema auditivo e termo-regulador. Segundo Hopkinson (1969)

\footnotetext{
"O que nos vemos depende nao somente da qualidade física da luz ou da cor presente, mas também do estado de nossos olhos na hora da visão e da quantidade de experiência visual que nos temos de lançar mão para nos ajudar no nosso julgamento... O que vemos depende não só da imagem que é focada na retina, mas da mente que a interpreta."
}

Portanto no processo de atribuir significado a um determinado estímulo ambiental o Homem envolve uma série de fatores: sua experiência pessoal, aspectos culturais, etc. Este caráter subjetivo da definição de conforto ambiental seja ele luminoso, térmico ou acústico é muito importante levar em consideração no projeto. 
Conforto é, portanto, a interpretação por meio de respostas fisiológicas e de sensações (inclusive com caráter subjetivo, de difícil avaliação), de estímulos físicos, objetivos e facilmente mensuráveis.

As variáveis do conforto luminoso que são levadas em conta são o clima, o lugar e o entorno, e as relacionadas ao edifício (cor, lâmpadas, materiais, etc) e seu entorno imediato (dentro do próprio terreno da edificação). Especificamente em relação ao clima, pode-se dizer que os fatores mais importantes e que afetam o padrão de conforto luminoso de um determinado ambiente são: a radiação solar, direta e difusa, a nebulosidade do lugar (tipo de céu) e a quantidade geral de luz natural disponível externamente (seus níveis de iluminância).

De acordo com Lambertz (1997) existem algumas condições que devem ser consideradas para alcançar o conforto lumínico:

$\checkmark$ Nível de iluminação, no Brasil a NBR 5413 fixa as iluminâncias mínimas a serem atingidas de acordo com o tipo de tarefa visual.

$\checkmark$ Ausência de ofuscamento, pois se o processo de adaptação não transcorre normalmente devido a uma variação muito grande da iluminação e ou a uma velocidade muito grande, experimenta-se uma perturbação, desconforto ou ate perda na visibilidade.

$\checkmark$ Contrastes adequados, que seria definido como a diferença entre luminância (brilho) de um objeto e a luminância de entorno imediato deste objeto.

É importante ressaltar que o projeto completo de conforto visual engloba a iluminação natural (feita análise do clima local) e a iluminação artificial através de lâmpadas, reatores, dimmers, etc. O conforto térmico e o conforto visual devem ser considerados em conjunto no projeto arquitetônico, balanceando a entrada de luz visível com a entrada de calor (parte infravermelha do espectro eletromagnético da luz) no ambiente.

Esta visão integrada torna possível o bom desempenho energético da arquitetura que sendo adequadas as necessidades do usuário, consumirá menos quantidade de energia para o condicionamento termolumínico. 


\section{Variáveis de conforto térmico}

São seis as variáveis principais determinam a quantidade de calor ou frio que uma pessoa sente, além dos outros fatores que influenciam diretamente o conforto térmico que são o metabolismo, a temperatura do ar, aclimatação na mudança de um local para outro, idade e sexo, tipo físico e condições de saúde.

\section{Fatores ambientais:}

- Temperatura do ar

- Velocidade do ar

- Umidade do ar (UR)

- Radiação (Temperatura radiante média)

\section{Fatores pessoais:}

- Atividade física

- Vestimenta

Outros fatores são:

- Metabolismo (biótipo, idade, peso, sexo, etc)

A temperatura do ar não é conseqüência da ação direta dos raios do sol, pois o ar é transparente a todos os comprimentos de ondas eletromagnéticas. O processo ocorre indiretamente - a radiação solar atinge o solo onde é absorvida em parte e transformada em calor. Portanto, a temperatura do solo aumenta e, por convecção, aquece o ar.

A temperatura do ar será conseqüência, portanto, de um balanço energético onde intervém:

- A radiação solar incidente e o coeficiente de absorção da superfície receptora; 
-A condutividade e a capacidade térmica do solo que determinam a transmissão de calor por condução;

-As perdas por evaporação, convecção e radiação.

Descrevendo detalhadamente os fatores principais, temos que (FROTA \& SCHIFFER, 2003):

- Umidade relativa do ar (UR): a umidade é caracterizada pela quantidade de vapor d'água contido no ar. Este vapor se forma pela evaporação da água, processo que supõe a mudança do estado líquido ao gasoso, sem modificação da sua temperatura. A umidade da pele evapora muito mais rapidamente em uma atmosfera seca do que úmida. Em uma situação de alta temperatura, a evaporação da pele é o canal mais importante de dissipação de calor. O ar saturado a $100 \%$ impede o resfriamento evaporativo.

- Velocidade do ar: traduz fisicamente o ar em movimento. No caso de regiões marítimas, durante o dia, o ar próximo ao solo se aquecerá, subirá e permitirá o movimento do ar fresco do mar para a terra. Durante a noite, a terra resfria mais facilmente e a água que armazenou o calor durante o dia, aquece o ar próximo permitindo a sua subida e a substituição pelo ar fresco vindo da terra. O movimento do ar pode produzir efeitos térmicos diferentes a diferentes temperaturas do ar, de duas maneiras:

* Aumenta a perda de calor por convecção, contanto que a temperatura do ar em movimento seja menor do que a temperatura da pele. Se não existir esta condição, na realidade o ar esquentará a pele.

* Acelera a evaporação, produzindo um resfriamento fisiológico. Seu efeito é insignificante em UR abaixo de $30 \%$, quando existe uma evaporação contínua mesmo em ar parado, e em umidades acima de $85 \%$, quando mesmo o movimento do ar não consegue ajudá-lo a adicionar vapor ao ar já saturado. Limites de movimento do ar agradáveis causam evaporação da pele, mais significativamente em UR médias $(40 \%-50 \%)$. 
- Radiação (Temperatura radiante média): ao lado da temperatura do ar, a radiação é que tem o maior efeito na sensação térmica. A radiação atingindo a superfície do corpo ativa os mesmos órgãos sensoriais que o calor do ar. Atingindo uma superfície intermediária, como a vestimenta, o calor radiante é convertido em radiação eletromagnética de ondas longas causando calor sensível (movimento molecular), que é então conduzido através do material para a pele.

- Atividade metabólica (MET): o corpo humano gera mais calor quando em movimento do que quando em repouso. Um princípio muito importante envolvido aqui é o da taxa de metabolismo. O corpo humano produz calor constantemente, mas a uma taxa variada. $\mathrm{O}$ metabolismo é o termo que descreve os processos biológicos do corpo que levam à produção de calor.

As tabelas contendo os valores $\mathrm{MET}^{1}$ para cada atividade específica podem ser encontradas em várias publicações especializadas. Porém, a utilização de valores de taxas metabólicas através destas tabelas pode levar a grandes erros de precisão, pois como as mesmas são estimadas levando-se em consideração apenas o tipo de atividade desempenhada e não consideram a pessoa que a está desempenhando, se homem ou mulher, baixa ou alta, jovem ou idosa, gorda ou magra, qual o esforço que está dispendendo para realizar a atividade, se adaptada ou não para o desempenho, qual seu condicionamento físico e metabolismo basal, quais seus hábitos de alimentação ou quais suas tensões ou nível de stress emocional.

\footnotetext{
${ }^{1}$ MET: O metabolismo, que varia de acordo com a atividade desempenhada é expresso em unidade "met". 1 met, que corresponde a 58,2 W/m².
} 
Desta forma, a utilização das tabelas torna-se um artifício bastante simplista, podendo induzir a erros na avaliação do conforto ambiental desejado.

- Vestimenta (CLO): o indivíduo pode exercer um controle considerável sobre a maioria das formas de trocas de calor entre a superfície do seu corpo e o ambiente através da escolha de suas roupas. A unidade clo foi inventada para simplificar o manuseio desta cobertura de isolamento. 1 clo $=6,5 \mathrm{~W} / \mathrm{m} 2{ }^{\circ} \mathrm{C}$ sobre toda a superfície do corpo. Em condições de ar parado, quando o indivíduo estiver em atividade sedentária, a variação de 1clo seria compensada por aproximadamente $7^{\circ} \mathrm{C}$ de mudança de temperatura. Em condições de vento forte, ou se o indivíduo estiver trabalhando pesado, o efeito seria mais pronunciado. As tabelas contendo os valores CLO para cada tipo de vestimenta específica podem ser encontradas em varias publicações especializadas. Devido à enorme gama de tecidos existentes no mercado atualmente, a utilização das tabelas nem sempre conseguem caracterizar com precisão o que está sendo realmente utilizado pelas pessoas, levando isso a utilização de valores incorretos.

\section{Índices de conforto térmico}

Os estudos de FANGER (1970) geraram um modelo analítico para a determinação das condições de conforto térmico, conhecido como modelo do PMV/PPD" - "Predicted Mean Value e Percentage of Dissatisfied People" - ou Voto Médio Estimado e Percentual de Pessoas Insatisfeitas, metodologia criada por Fanger que leva em consideração as seis variáveis citadas no subitem anterior.

\footnotetext{
2 O modelo PMV/PPD baseia-se o princípio físico do balanço térmico entre o homem e o ambiente, correlacionando as sensações térmicas das pessoas à carga térmica atuando sobre o corpo, a qual é definida como sendo a diferença entre a produção interna de calor pelo corpo, através da taxa metabólica, e os mecanismos de transferência de calor do corpo para o ambiente.
} 
XAVIER (2000) em sua tese de doutorado questiona o modelo PMV/PPD, porque para distintas situações geográficas de edificações e populações analisadas, tem mostrado pouca convergência entre os resultados por ele apresentados e as sensações de conforto térmico relatadas pelas pessoas. Considera que esta metodologia pode levar a predições de sensações térmicas não correspondentes à realidade, uma vez que não consideram algumas características individuais das pessoas analisadas ao correlacionar os processos físicos de transferência de calor com um processo subjetivo das pessoas, que são suas sensações.

As variáveis incluídas no estudo de XAVIER (2000) foram referenciadas como relativas ao estilo de vida, no que diz respeito a hábitos de atividades físicas, hábitos alimentares e nível de estresse verificado pelas pessoas, além de idade, sexo e composição corporal, considerados tão ou mais importantes do que os próprios mecanismos de troca de calor. Tal fato já foi apontado também por outros pesquisadores, como AULICIEMS (1973), HUMPHREYS e NICOL (1996), ARAÚJO (1996) e XAVIER E LAMBERTS (1999).

VERGARA, L.G. (2001) em sua dissertação de mestrado analisando as condições de conforto térmico em trabalhadores da UTI (Unidade de Tratamento Intensivo) do Hospital Universitário de Florianópolis, demonstrou que praticamente não houve correlação entre o PMV calculado e as sensações térmicas relatadas pelos trabalhadores durante as medições, ou seja, somente $3,54 \%$ das variações de sensações térmicas dos trabalhadores da UTI são explicadas pelo modelo do PMV.

Por outro lado, a impossibilidade de se expressar a resposta humana ao ambiente térmico em função de um simples fator ambiental, e na certeza de que cada um age influenciado por diversos fatores, vários Índices Térmicos surgiram. Entre eles, GIVONI (1976) cita o E.T. "Effective Temperature Index", proposto pela ASHRAE; o R.T. - "Resultant Temperature", proposto pelo francês Missenard; o P4S.R. - "Predicted Four Hours Sweat Rate", proposto pelo Centro de Pesquisa da Marinha Real da Inglaterra durante a II Grande Guerra; o H.S.I. - "Heat Stress Index", proposto pelos pesquisadores Belding e Hatch, da Universidade de Pittsburg; e finalmente o I.T.S. - "Index Thermal Stress". 


\section{Carta bioclimática}

Ao ser abordada a temática da zona de conforto, procura-se traçar estratégias bioclimáticas normativas através da aplicação da Bioclimatologia à Arquitetura calçadas em estudos de cartas bioclimáticas que permitam identificar, a partir de uma análise climática local, parâmetros para desenvolvimento de projetos arquitetônicos.

GIVONI (1976) afirma que, além de o clima em dada região ser determinado pela variação e inter-relação de diversos elementos, os principais fatores climáticos a serem considerados para se dotar uma edificação e seus ocupantes de conforto térmico são: radiação solar, radiação de onda longa emitida da Terra para a atmosfera, temperatura do ar, velocidade do ar, umidade relativa e precipitação (chuva, neve, etc), considerando-se que a manutenção do equilíbrio térmico entre o corpo humano e seu ambiente é um dos principais requisitos para a saúde, o bem estar (produtividade) e o conforto.

$\mathrm{Na}$ década de 60 , os irmãos Olgyay fizeram uso da Bioclimatologia na Arquitetura levando em consideração os princípios do conforto térmico humano. Givoni desenvolveu um diagrama bioclimático que propunha estratégias de adaptação da Arquitetura ao clima (LAMBERTS et al, 1997). Entre esses dois sistemas há duas diferenças básicas: a) o sistema de Olgyay é desenhado entre dois eixos, sendo o vertical das temperaturas e o horizontal das umidades relativas, enquanto que o de Givoni é traçado sobre uma carta psicométrica convencional; e b) o sistema de Givoni se baseia em temperaturas internas do edifício obtidas por projeção, enquanto que o de Olgyay só se aplica para as condições externas. Ambos os sistemas apresentam alternativas para dilatar a zona de conforto através da adoção de estratégias arquitetônicas para alterar a sensação do clima interno em estudo (BARBOSA, 1997)

De acordo com GIVONI (1992) o clima interno em edifícios não condicionados reage mais à variação do clima externo e a experiência de uso dos habitantes dos mesmos. Pessoas que moram em edifícios sem condicionamento e naturalmente ventilados aceitam usualmente 
uma grande variação de temperatura e velocidade do ar como situação normal. Assim Givoni concebeu uma carta bioclimática adequada para países em desenvolvimento, expandindo os limites máximos de conforto expressos em sua carta anterior.

Foi adaptada uma carta bioclimática a partir da sugerida por GIVONI (1992), para a Norma Brasileira de Desempenho Térmico em Edificações, Parte 3: Zoneamento Bioclimático Brasileiro e Diretrizes para Habitações Unifamiliares de Interesse Social (RORIZ et al, 1999).

Após analisadas diversas cartas bioclimáticas por BOGO et al. (1994) e adotando-se a proposta por GIVONI (1976) para países em desenvolvimento, na seqüência, o NPC/LABEEE/ ECVIUFSC desenvolveu um programa computacional denominado ANALYSIS BIO (UFSC, Labee) para utilização das recomendações e estratégias bioclimáticas, visando adequar a arquitetura do clima local, relacionando variáveis como a temperatura de bulbo seco, temperatura de bulbo úmido, umidade relativa e especifica, entalpia, ponto de orvalho, volume específico e pressão de vapor.

\section{Diagrama solar ou Carta solar}

O diagrama solar utilizado nesse trabalho é o disponibilizado no livro de Frota (1998). Ele existe em algumas versões informatizadas, como a desenvolvida pelo Prof. Maurício Roriz, o Luz do Sol 1.1 ou o programa Sol-Ar do Labeee, da Universidade Federal de Santa Catarina. A figura 02 mostra versão informatizada do diagrama solar: 


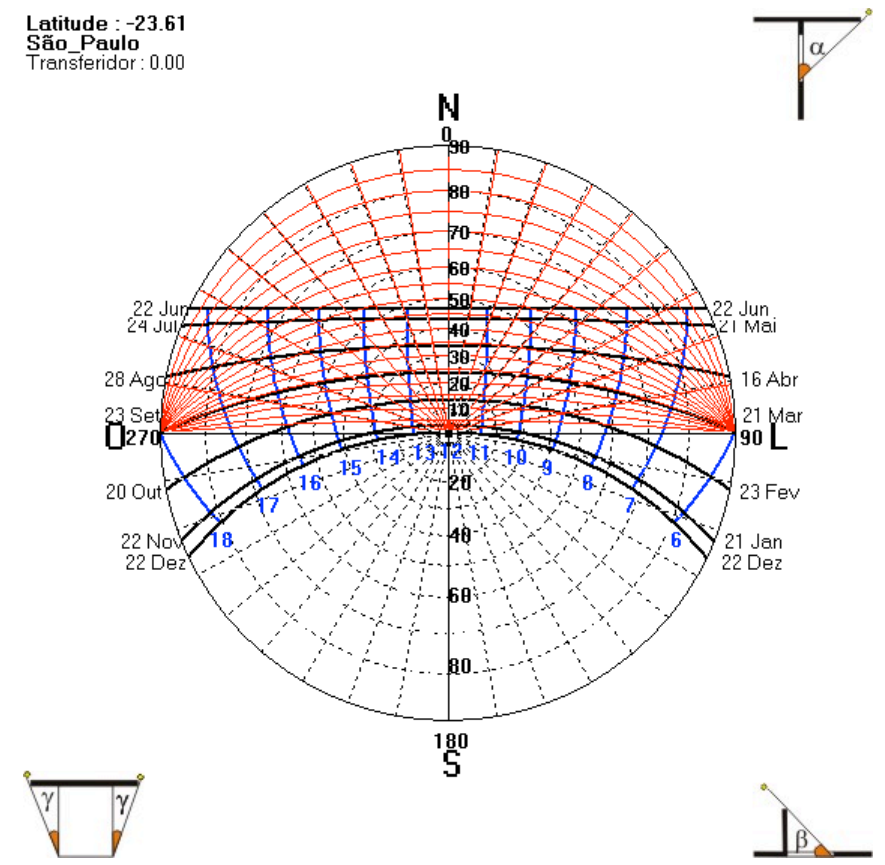

Figura 02: Diagrama solar na versão informatizada.

Fonte: Sol-AR, 2012.

O diagrama solar nos permite trabalhar a geometria do projeto de forma a estabelecer as melhores relações com a insolação, usando as informações do diagrama de Givoni. Em função deste conhecimento é possível administrar o projeto, suas sombras integradas (beirais, brises, varandas) e sua relação com o entorno de forma a captar a radiação solar nos momentos em que ela se adéque às estratégias levantadas no diagrama de Givoni para um período determinado.

Durante o desenvolver de um projeto arquitetônico são retiradas as informações da posição do sol, ou seja, conhecer a direção de seus raios, e, sobretudo, suas projeções horizontal e vertical. Dessa forma, trabalha-se em planta e em corte a edificação: dimensionando as fachadas mais expostas à radiação, prevendo aberturas, calculando a forma de suas proteções.

O valor da radiação solar varia de acordo com a orientação. Ela também varia de acordo com os dias do ano, como resultado da maior ou menor proximidade e inclinação dos raios solares. O Sol possui uma trajetória aparente que varia ao longo do dia e ao longo do ano. 
Entretanto, para cada latitude, essa trajetória teoricamente se repete a cada ano. Assim, para cada local, segundo a hora do dia, a estação do ano e a orientação escolhida, é possível trabalhar sempre uma única posição espacial e um único valor de radiação com pequenas margens de erro. Dessa forma, podem-se deduzir as fachadas mais expostas à radiação, para dimensioná-las e calcular a forma de suas proteções (beirais e brises).

A posição espacial do Sol pode ser reproduzida no projeto em função da sua altura solar (a) e o seu azimute (a). Tal como para o diagrama bioclimático de Givoni, a versão informatizada deste instrumento ajuda bastante na escolha da organização interna dos ambientes, e na construção das sombras integradas à edificação ou no entorno.

\section{As normas Gécnicas 5413 (ISO 8995), 15220 e 15575}

A norma NBR-5413 - "Iluminância de interiores / Especificação" da ABNT - Associação Brasileira de Normas Técnicas, em vigor a partir de abril de 1982, trata basicamente dos níveis de iluminância mínimos e médios para as diferentes tarefas visuais. Estabelece como condições gerais principais:

1 - A iluminância deve ser medida no campo de trabalho. Quando este não for definido, entende-se o nível do referente a um plano horizontal a $0,75 \mathrm{~m}$ do piso;

2 - No caso em que seja necessária uma elevada iluminância em um limitado campo de trabalho, este pode ser conseguido com iluminação suplementar;

3 - A iluminância no restante do ambiente deve ser inferior a 1/10 do valor adotado para o campo de trabalho, mesmo que a iluminância recomendada para o restante do ambiente seja menor.

A norma também apresenta procedimento para determinação da iluminância conveniente segundo a idade, a velocidade e precisão necessárias para a realização da tarefa e também da 
refletância do fundo da tarefa visual. No quadro 01 de acordo com a norma, para residências, a iluminância mínima exigida (em lux) para os ambientes são:

\begin{tabular}{|l|l|l|l|}
\hline \multicolumn{4}{|c|}{ Sala de estar } \\
\hline Geral & 100 & 150 & 200 \\
\hline Local (leitura, escrita, etc) & 300 & 500 & 750 \\
\hline \multicolumn{3}{|c|}{ Cozinhas } \\
\hline Geral & 100 & 150 & 200 \\
\hline Local (fogão, pia, mesa) & 200 & 300 & 500 \\
\hline Germitórios & 100 & 150 & 200 \\
\hline Local (espelho, cama) & 200 & 300 & 500 \\
\hline Hall, escadas, despensas e garagens \\
\hline Geral & 75 & 100 & 150 \\
\hline Local & 200 & 300 & 500 \\
\hline \multicolumn{1}{|c|}{ Banheiros } & & \\
\hline Geral & 100 & 150 & 200 \\
\hline Local (espelhos) & 200 & 300 & 500 \\
\hline
\end{tabular}

Quadro 01: lluminância para cada grupo de tarefas visuais.

Fonte: adaptada NBR 5413.

A NBR 15220-3 (ABNT, 2005) apresenta o Zoneamento Bioclimático Brasileiro e as Diretrizes Construtivas para Habitações Unifamiliares de Interesse Social. De acordo com esta classificação, o Brasil foi subdividido em oito zonas como demonstra a figura 03. 


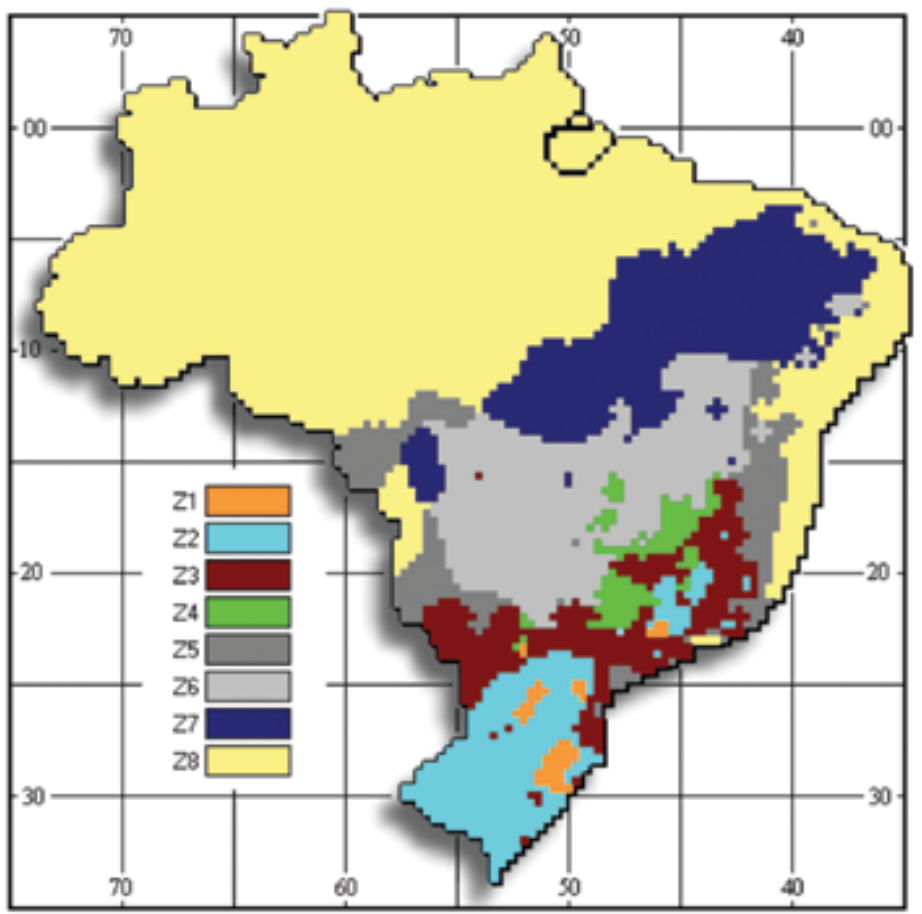

Figura 03: Zoneamento bioclimático brasileiro.

Fonte: ABNT, 2005.

As diretrizes construtivas são específicas para cada zona bioclimática e a avaliação é prescritiva, realizada com base na verificação do atendimento de cada parâmetro identificado pela norma, a saber:

-Tamanho das aberturas para ventilação (expressas como percentual de área de piso);

-Proteção das aberturas;

-Vedações externas, parede externa e cobertura, informando o tipo de vedação (leve ou pesada, refletora ou isolada);

-Estratégias de condicionamento térmico passivo.

Embora a norma faça referência à habitação de interesse social, as recomendações e diretrizes que expressa visam à otimização do desempenho térmico e são fundamentadas em estratégias de adaptação da edificação ao clima. Portanto, a NBR 15220-3 é uma importante referência normativa para a prescrição de estratégias bioclimáticas a serem incorporadas no 
projeto de edificações. As estratégias de condicionamento ambiental recomendadas pela NBR 15220-3 são baseadas na carta bioclimática de Givoni (1992) e nas planilhas de Mahoney (KOENIGSBERGER et al., 1977).

A classificação de cada cidade em uma determinada zona depende das estratégias bioclimáticas, que são definidas previamente, tendo sido utilizadas as planilhas de Mahoney para a definição dos limites das propriedades térmicas dos elementos construtivos (paredes e coberturas): Transmitância Térmica, Atraso Térmico e Fator Solar ${ }^{3}$ (ABNT, 2005). Também são indicados percentuais de área de piso relativos às aberturas para ventilação, classificando-as em pequenas, médias ou grandes.

\footnotetext{
${ }^{3}$ Transmitância térmica $(U)$ é uma propriedade dos componentes construtivos relacionada à permissão da passagem de energia, medida em $\mathrm{W} / \mathrm{m} 2 \mathrm{~K}$. Está relacionada à espessura do componente e à condutividade térmica dos seus materiais constituintes, e representa sua capacidade de conduzir maior ou menor quantidade de energia por unidade de área e de diferença de temperatura. Atraso térmico $(\phi)$ indica o tempo transcorrido entre uma variação térmica em um meio e sua manifestação na superfície oposta de um componente construtivo. Por exemplo: o tempo transcorrido entre o pico de temperatura máxima do ar externo e a temperatura máxima do ar em um ambiente interno. Fator solar (FSo): em componentes opacos, representa o quociente da taxa de radiação solar transmitida através do componente pela taxa da radiação solar total incidente sobre a superfície externa do mesmo.
} 
Neste trabalho, o projeto arquitetônico da residência, por estar localizada em Cajobi, SP, está inserida na zona bioclimática 6 . Neste caso, as diretrizes construtivas recomendadas pela NBR 15220-3 relativas a estratégias de condicionamento térmico são: Resfriamento evaporativo e massa térmica para resfriamento, Ventilação seletiva (períodos em que a temperatura interna seja superior à externa, ou seja, no período do inverno) e Vedações internas pesadas (inércia térmica). A figura 04 mostra a zona bioclimática em que está inserida a cidade de Cajobi, e a carta biocliamática apresentando as normais climatológicas:
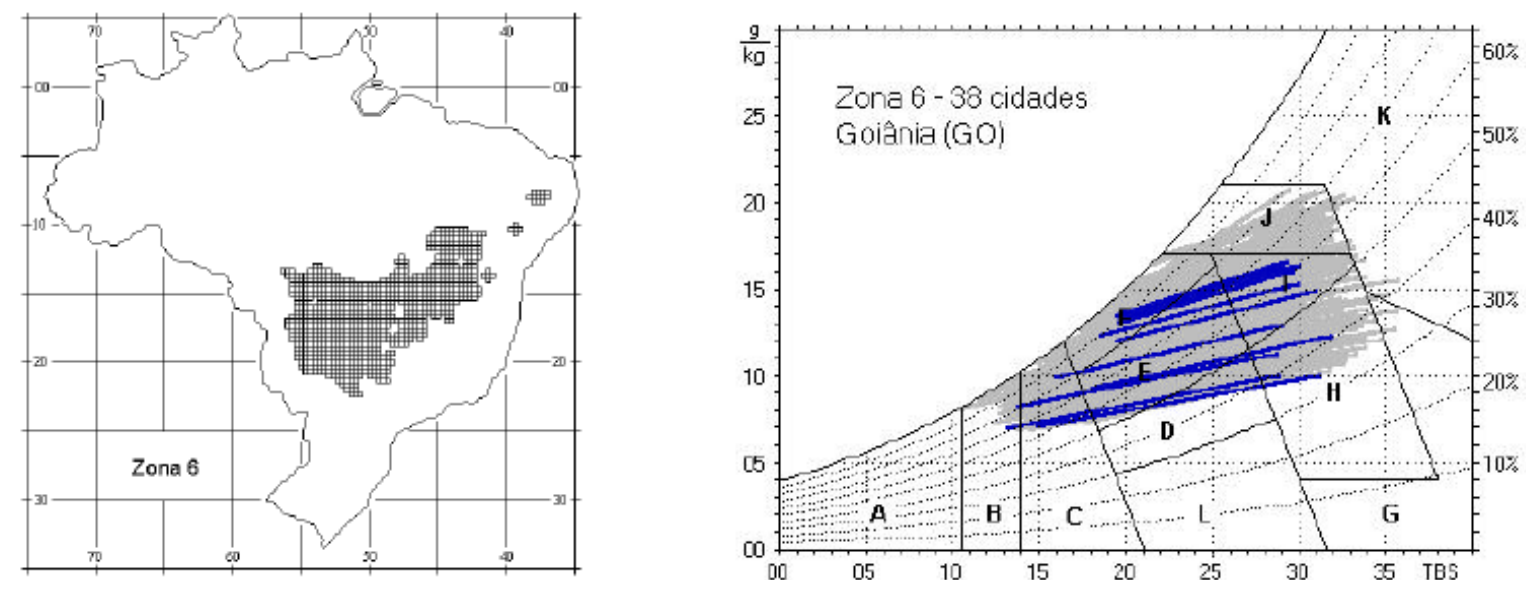

Figura 04: Zona bioclimática 6 e carta bioclimática para a respectiva zona.

Fonte: ABNT, 2005.

A norma ainda prevê algumas recomendações de projeto para a Zona 6:

1.Aberturas médias (entre $15 \%$ a $25 \%$ da área do piso do ambiente);

2.Sombrear essas aberturas;

3.Vedações externas pesadas com transmitâncias térmicas com $U \leq 2,20 \mathrm{~W} / \mathrm{m}^{2}$. $\mathrm{K}$, atraso térmico de $\phi \geq 6,5$ horas e fator solar de $F S=\leq 3,5 \%$;

4.Coberturas leves e isoladas com transmitâncias térmicas com $\mathrm{U} \leq 2,00 \mathrm{~W} / \mathrm{m}^{2}$. $\mathrm{K}$, atraso térmico de $\phi \leq 3,3$ horas e fator solar de $\mathrm{FS}=\leq 6,5 \%$. 
A NBR 15575: Edificações habitacionais de até cinco pavimentos - Desempenho é uma norma lançada em 2008 e o escopo desta norma é abrangente, definindo-se requisitos de desempenho mínimo obrigatório para alguns sistemas das edificações, considerando-se as necessidades dos usuários e as condições de exposição da edificação, ao longo de uma vida útil mínima obrigatória.

O desempenho térmico é um dos requisitos qualitativos de desempenho, sendo os critérios de avaliação os valores máximos de temperatura interna no verão e os valores mínimos de temperatura interna no inverno. Na NBR 15575, o desempenho térmico pode ser classificado e é um dos requisitos que deve ser contemplado adequadamente pelos sistemas de vedações verticais internas e externas, assim como pelos sistemas de cobertura.

A norma estabelece três procedimentos de avaliação: prescritiva (semelhante à NBR 15220-3); simulação computacional e medição. Quando se utiliza a medição, a temperatura do ar é monitorada nas edificações ou protótipos construídos, considerando-se os dias típicos de projeto de inverno e verão, específicos de cada local (ABNT, 2008). A classificação dos níveis de desempenho é feita de acordo com a adequação do projeto aos critérios estabelecidos pela norma, em três categorias: nível M (mínimo), I (intermediário) ou S (superior).

Com relação às fachadas, a norma define apenas os requisitos mínimos que devem ser atendidos, referentes à classificação de nível de desempenho mínimo: as propriedades termofísicas transmitância e capacidade térmica, de acordo com a absortância da superfície externa.

Para o projeto localizado na zona bioclimática 6 , os valores dessas propriedades encontram-se enumerados nos quadros 02 e 03. 


\begin{tabular}{|c|c|c|}
\hline Nível de desempenho & \multicolumn{2}{|c|}{ Transmitância térmica Zona 6 } \\
\hline M & Absortância $<0,6$ & Absortância $\geq 0,6$ \\
\hline & $U \leq 3,7$ & $U \leq 2,5$ \\
\hline
\end{tabular}

Nota: valores de transmitância térmica considerando-se a resistência superficial interna com valor de $0,13 \mathrm{~m}^{2} . \mathrm{K} / \mathrm{W}$ e a resistência supeficial externa com valor de $0,04 m^{2} . K / W$. Absortância é a radiação solar da superfície externa da parede.

Quadro 02: Critério e nível de desempenho de paredes externas quanto à transmitância térmica.

Fonte: adaptado ABNT, 2008.

\begin{tabular}{|c|c|}
\hline Nível de & $\begin{array}{c}\text { Capacidade térmica (CT, em } \\
\text { desempenho }\end{array}$ \\
\hline $\left.\mathbf{K J} /\left(\mathbf{m}^{\mathbf{2}} \cdot \mathbf{K}\right)\right)$ \\
\hline
\end{tabular}

Quadro 03: Critério e nível de desempenho de paredes externas quanto à capacidade térmica.

Fonte: adaptado ABNT, 2008.

Com relação às coberturas, são indicados parâmetros para classificação do nível de desempenho como mínimo (M), intermediário (I) e superior (S), determinado de acordo com a transmitância térmica, em função da absortância. A norma também recomenda que elementos com capacidade térmica maior ou igual a $150 \mathrm{~kJ} /\left(\mathrm{m}^{2} \mathrm{~K}\right)$ não sejam empregados sem isolamento térmico ou sombreamento. O quadro 04 é elaborado através da norma para demonstrar os valores de transmitância térmica para coberturas de acordo com a respectiva zona bioclimática.

\begin{tabular}{|c|c|}
\hline \multicolumn{2}{|c|}{ Transmitância Térmica $(\mathbf{U}) \mathbf{w} / \mathbf{m}^{\mathbf{2}} \mathbf{k}$} \\
\hline $\boldsymbol{\alpha} \leq \mathbf{0 , 6}$ & $\alpha>0,6$ \\
\hline $\mathbf{U} \leq \mathbf{2 , 3 0}$ & $\mathrm{U} \leq 1,5$ \\
\hline
\end{tabular}

Quadro 04: Critério de coberturas quanto à transmitância térmica.

Fonte: adaptado ABNT, 2008. 
Com relação às áreas de abertura, as recomendações da norma só se aplicam aos ambientes de longa permanência: salas, cozinhas e quartos. É obrigatória a existência de dispositivos de sombreamento nas janelas dos quartos, de forma a permitir o controle do sombreamento, ventilação e escurecimento, a critério do usuário, como por exemplo, venezianas. Nestes casos, a norma recomenda aberturas médias, com área efetiva de ventilação equivalente a $8 \%$ de área de piso dos ambientes, no mínimo, e durante o inverno serem vedadas.

A NBR 15575 apresenta, ainda, os procedimentos de medição e de simulação. O procedimento de medição consiste na medição da temperatura de bulbo seco no centro dos quartos e salas, a 1,20 m do piso, no dia considerado dia típico de projeto, no verão e no inverno. Esses dias são determinados em função da temperatura máxima e da temperatura mínima típicas da localidade onde será feita a medição. A NBR 15575 apresenta valores de temperatura a serem considerados como referência para a seleção do dia típico das capitais brasileiras, obtidos a partir das Normais Climatológicas. A recomendação da norma é trabalhar com uma sequência de três dias e analisar os dados do terceiro dia, a fim de garantir que a edificação entrou em regime permanente.

No quesito iluminação a NBR15575 prevê os níveis mínimos de iluminâncias tanto natural quanto artificial, para alguns ambientes de maior permanência de um edifício habitacional. Para sala, dormitório, cozinha, banheiro e área de serviço são exigidos um nível mínimo de iluminação natural de 60 lux e artificial de 100 lux. 


\subsection{GFICIÊnCIA EnERGÉGICA G ARQUIGGGURA}

\subsubsection{Variáveis Ārquitetônicas}

A evolução do desempenho dos ambientes edificados nos últimos vinte anos não acompanhou a verdadeira revolução de outras áreas da produção humana. Muitas casas, escritórios, escolas e outros prédios onde as pessoas passam $90 \%$ de seu tempo, não tem um desempenho melhor do que aqueles construídos pela geração passada. De fato, a noção de que uma edificação deva ter um alto desempenho é nova para muitos, apesar de que a maior parte do ambiente construído a nível global ter um custo real que pode ser mensurado em nível de poluição ambiental, dólares, e da qualidade de vida da população.

A indústria da construção civil produziu inovações em certos produtos específicos, tecnologias, materiais, ferramentas de projeto e métodos construtivos. É fácil citar sistemas de aquecimento e refrigeração eficientes, controles de iluminação, painéis fotovoltaicos que substituem as telhas, vasos sanitários de vazão reduzida, sistemas de automação predial. Porém a maior parte das edificações recentes não integra estes progressos para obter um todo que seja maior do que a soma de suas partes. As edificações deveriam ser melhores para nós, para o meio ambiente, e para a economia. E elas serão melhores - existe o conhecimento e as ferramentas para tal - se os legisladores, os programas federais, e os lideres da indústria fizerem um esforço acordado para coordenar programas e recursos na abordagem sistêmica da "Alta Qualidade Ambiental das Edificações".

$\mathrm{Na}$ realidade verifica-se que o primeiro passo para atingir a alta qualidade ambiental é entender como a edificação interage com o meio ambiente ao seu redor, sobretudo no aspecto térmico.

Milhões de pessoas que habitam em regiões metropolitanas estão sujeitas ao efeito das ilhas de calor, que faz com que as temperaturas nas cidades cheguem a ser de $1^{\circ}$ a $6^{\circ}$ Graus 
Celsius mais quentes do que em áreas rurais vizinhas. Esta elevação de temperatura pode causar impactos nestas comunidades pelo aumento da demanda de energia de pico, custos de ar condicionado, perda de produtividade, níveis de poluição do ar e doenças causadas pelo calor. Este fenômeno se forma à medida que as cidades substituem a cobertura natural dos terrenos por áreas pavimentadas, edifícios, e infraestrutura (GRAY e FINSTER, 2000). Estas modificações contribuem para a elevação da temperatura urbana de várias maneiras:

- a retirada de árvores e vegetação minimiza os efeitos de resfriamento natural que sombra e a evaporação da água do solo e das folhas proporcionam (evapotranspiração);

- edifícios altos e ruas estreitas aquecem o ar preso entre eles e reduzem o fluxo de ar;

- calor e poluição produzidos por veículos, fábricas e ar condicionados aquecem seus arredores, aumentando o efeito da ilha de calor.

OLGYAY (1998) afirma que são muitas as características em um projeto de arquitetura que afetam a edificação, pelo que indica quatro formas de interação da construção com o seu meio ambiente:

- A efetiva exposição solar - dos elementos envidraçados ou opacos do envelope (paredes e cobertura);

- O efetivo ganho de calor solar do edifício;

- A taxa de ganho ou perda condutiva e convectiva de calor para o ar ambiente;

- O potencial para ventilação natural e resfriamento passivo do edifício.

Afirma ainda que as principais características que afetam alguma ou todas dessas interações do edifício com o meio ambiente são parte das estratégias solares passivas:

- Forma do edifício;

- Orientação e condições de sombreamento das janelas;

- Orientação e cor das paredes;

- Tamanho e localização das aberturas sob aspecto de ventilação;

- Efeito da condição de ventilação da edificação na sua temperatura interna; 
- Especificação dos materiais do envelope.

Os resultados destas intervenções devem ser complementados, quando necessário, com estratégias e tecnologias ativas - equipamentos para atingir os níveis adequados de desempenho.

O calor flui de espaços com temperaturas mais altas para os com temperatura mais baixa, até atingir o equilíbrio. Induzido por diferenças de temperatura, a troca de calor ocorre por condução, convecção e radiação (FROTA, 2001). Condução é o movimento do calor dentro de uma substância. Por exemplo, o metal é um excelente condutor de calor, fazendo com que elementos da edificação feitos de metal, como portas, janelas, paredes, tetos e pisos sejam áreas especialmente difíceis para controlar a transferência de calor. Convecção é a movimentação do calor através de um fluido: prismas de elevador, cavidades de paredes não isoladas, e outros espaços verticais onde o ar está em movimento e suscetível a transferência de calor por convecção. Radiação é a movimentação do calor através de ondas eletromagnéticas: objetos a temperaturas acima de zero absoluto irradiam calor. A única maneira de alterar o fluxo de calor radiativo é com a inserção de um objeto que desvie ou absorva o calor entre os objetos emissor e receptor.

As estratégias de projeto podem incluir vários tipos de isolamento térmico, variação de formas, cores internas e externas, resfriamento evaporativo, ventilação natural e forçada, especificação de envidraçamentos e janelas, tipos de coberturas e telhados, de fundações, tipos de portas, paisagismo interno e externo, etc. É importante ressaltar que cada tipo de clima requer estratégias diferentes e específicas. 


\subsubsection{O Envelope: Fechamentos Opacos e Granslúcidos}

O envelope de uma edificação pode ser definido como a interface construtiva com o exterior. Regulam os três tipos de trocas de calor para auxiliar no controle da temperatura interna da mesma, ao responder às variáveis externas (temperatura do ar, albedo, radiação direta, etc), e variáveis internas (carga térmica dos ocupantes, iluminação, equipamentos, etc).

Estratégias de especificação deste envelope podem fazer com que os ocupantes controlem estas trocas de calor, permitindo que mais ou menos calor flua de e para o ambiente externo conforme as condições de conforto assim o exijam. A definição do envelope (paredes, janelas, portas, telhados, forros e pisos) será um fator determinante na quantidade de energia que a edificação irá gastar na sua operação. Os impactos ambientais de ciclo de vida e custos energéticos associados com a produção e transporte dos diferentes tipos de materiais do envelope também variam muito e devem ser cuidadosamente considerados.

No clima tropical quente úmido, as construções (especialmente as com uso noturno, como as residenciais) não devem ter uma inércia muito grande, pois isto dificulta a retirada do calor interno armazenado durante o dia pelo envelope, prejudicando o resfriamento da edificação quando a temperatura externa noturna está mais baixa que a interna. As recomendações usuais preveem uma inércia de média a leve, porém prestando atenção para que as vedações sejam estanques e também que contenham algum material isolante, para impedir que grande parte do calor da radiação solar recebido pelas vedações atravesse a edificação e gere calor interno em demasia.

O mesmo se aplica à cobertura, que pode ter espaços de ar ventilados, que tem como característica retirar o calor que atravessa as telhas e que, deste modo, não penetrará nos ambientes. A grande causa de desconforto térmico no verão neste clima são as altas taxas de umidade e temperaturas externas elevadas. 
No entanto o clima caracterizado pela região de estudo é tropical quente alternando seco no inverno e úmido no verão. De acordo com a NBR 15220 as paredes devem ser pesadas, levando em consideração as temperaturas de inverno.

A EPA (Environmental Protection Agency) dos Estados Unidos estima que a demanda anual de energia para ar condicionado seja de quase $1 / 6$ da energia total gerada. A especificação cuidadosa de materiais de construção e seus respectivos albedos pode ter um efeito significativo no ganho de calor de superfícies, assim como nas temperaturas do ar ambiente, que por sua vez podem reduzir a demanda por ar-condicionado.

Novos estudos indicam que superfícies reflexivas, especialmente as utilizadas em coberturas, podem ajudar a reduzir a demanda por resfriamento. Isto pode resultar em economia de energia (DORNELLES, 2008).

A especificação do envelope pode requerer alguns entre os vários tipos de proteção solar, que incluem pérgulas, toldos, cobogós, venezianas, vegetação, marquises, etc. As proteções móveis são mais caras, porém podem oferecer proteção variável de acordo com o período do dia e do ano. Além das vantagens como sistema de resfriamento passivo, a proteção solar é um dos recursos de conforto térmico que interferem no volume externo da arquitetura. Assim, ao especificar um brise, o arquiteto estará tomando partido também de decisões plásticas.

A proteção solar também influenciará a qualidade e a quantidade de luz natural que passa ao interior da edificação. Jean Nouvel concebeu no Instituto do Mundo Árabe um tipo de brise que controla automaticamente a intensidade de luz solar no interior. Em forma de diafragmas e movidos por sensores de luz, estes brises compõem um interessante efeito de "tapeçaria" na fachada do edifício, em referência conceitual ao mundo árabe, conforme mostra a figura 05 (REVISTA PROJETO, 1989). 


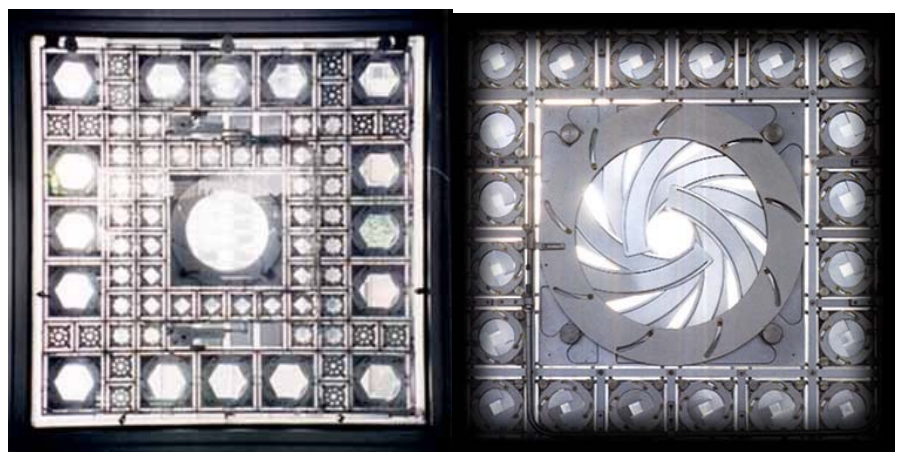

Figura 05: Brise do Instituto do Mundo Árabe, fechado e aberto.

Fonte: Revista Projeto, 1989.

\subsubsection{Implantação e Orientação Solar}

No que se refere à disposição das edificações nos lotes urbanos, elas devem estar dispostas de modo a permitir que a ventilação atinja todos os edifícios e possibilite a ventilação cruzada nos seus interiores (ABNT, 2005). Isto significa que o partido arquitetônico deve prever construções alongadas no sentido perpendicular ao vento dominante.

Segundo POPOV, L.A. (2002) a morfologia, do ponto de vista da percepção humana e da teoria da arquitetura, pode ser descrita em termos de formato, forma, sólidos e vazios, massa e espaço, e o layout de espaço e estruturas edificadas - e como isto afeta a relação da edificação com o entorno e também as instalações mecânicas da construção.

Para Normam Foster, grande investigador da técnica associada à alta tecnologia e ao uso da computação, a forma será o resultado de diversos condicionantes bioclimáticos, buscando sempre alcançar o máximo aproveitamento da luz natural e a eficiência energética (DI TRAPPANO E BASTOS, 2005). Para Ken Yeang, seus projetos não surgem simplesmente de uma concepção solitária, mas a partir de uma total compreensão da ecologia e de sistemas sustentáveis, que são os motivos geradores de suas formas (RICHARDS, 2001).

Em sua dissertação de mestrado, BARROSO-KRAUSE (1989) identifica que na região da Baixada da Penha, no Rio de Janeiro, apesar de contar com ventos de valores iniciais bastante 
altos, esta vantagem é praticamente anulada face à rugosidade de um entorno extremamente mal elaborado.

Quanto à radiação solar direta, devem-se proteger as aberturas nos períodos mais quentes do dia. As mesmas janelas que fornecem uma bela vista, iluminação natural e ventilação podem estar adicionando muito calor ao ambiente interno, e consequentemente aumentando os gastos com condicionamento de ar. Para que uma janela seja eficiente do ponto de vista energético, será necessário analisar a orientação das mesmas. O importante é saber da necessidade da determinação da posição do Sol para o local em questão, na época do ano em que se deseja barrar seus raios diretos. Não se pode esquecer, porém que o uso da radiação solar no ambiente interno (luz/calor) é apropriada em certos casos:

- Ajuda no crescimento das plantas;

- lluminação natural, que oferece mais conforto e produtividade, dando dinamismo ao espaço interno através de sua variação ao longo do dia;

- Oferece um elo emocional e visual com o ambiente externo;

- Propriedade germicida em relação a fungos;

Para fazer um controle eficiente da radiação solar é necessário saber a latitude do local, que é o dado que vai fornecer as trajetórias aparentes do sol a qualquer hora de qualquer dia de qualquer ano (azimute e altura solar). As áreas de sombra e de sol podem ser estudadas com a ajuda de gráficos de trajetórias solares e um transferidor solar, que representam a projeção, sobre um plano, das trajetórias aparentes sobre a abóbada celeste, para vários dias do ano. Atualmente existem vários softwares para se estudar a insolação nas edificações, como o Luz do Sol, Visual DOE, o ECOTEC e o The Sun Tool. 


\section{O diagnóstico do microclima}

Além do tipo de clima, para todo estudo arquitetônico, é necessário o conhecimento do microclima envolvido, ou seja, o clima do entorno próximo. Os valores que encontramos nas estações meteorológicas são medidos em circunstâncias muito especiais, e em geral, distintas daquelas do nosso dia a dia. É necessário um estudo, sobre planta de relevo, para verificar as mudanças ocasionadas por topografia, cobertura vegetal, densidade urbana, etc.

As montanhas, e construções vizinhas ao entorno do lote podem: esconder a radiação solar direta; refletir os raios de Sol; obstruir e modificar o sentido ou a velocidade dos ventos dominantes. No estudo do microclima existe um limite além do qual, o assunto torna-se estudo de urbanismo, escapando às possibilidades de intervenção do arquiteto. Dessa forma, é preciso avaliar apenas o impacto do entorno próximo à edificação - entorno natural, construído ou legislado - sobre a performance da construção. O objetivo é conseguir identificar os elementos específicos deste entorno capazes de modificar os dados climáticos padrão das estações meteorológicas.

De acordo com o Proceledifica (2011) para uma primeira definição das estratégias bioclimáticas de projeto, não sendo possível conseguir os dados das estações climatológicas, uma pesquisa no terreno pode ajudar a determinar qual o tipo de clima em questão. Medem-se os valores médios (média das médias) da temperatura do ar e da umidade dos meses extremos, que são os piores, e aplica-se no quadro 05. 


\begin{tabular}{|c|c|c|c|}
\hline Temperatura & Diagnóstico & Umidade absoluta & Diagnóstico \\
\hline \multirow{2}{*}{$<10^{\circ} \mathrm{C}$} & \multirow{2}{*}{ Frio } & $>6 \mathrm{~g} / \mathrm{Kg}$ & Úmido \\
\hline & & $<4 \mathrm{~g} / \mathrm{kg}$ & Seco \\
\hline \multirow{2}{*}{$10^{\circ} \mathrm{C}$ a $20^{\circ} \mathrm{C}$} & \multirow{2}{*}{ Temperado } & $>6\left(10^{\circ} \mathrm{C}\right)$ e $>9 \mathrm{~g} / \mathrm{kg}\left(10^{\circ} \mathrm{C}\right)$ & Úmido \\
\hline & & $<4 \mathrm{~g} / \mathrm{kg}$ & Seco \\
\hline \multirow{2}{*}{$20^{\circ} \mathrm{C}$ a $30^{\circ} \mathrm{C}$} & \multirow{2}{*}{ Quente } & $>10\left(20^{\circ} \mathrm{C}\right)$ e $>16 \mathrm{~g} / \mathrm{kg}\left(30^{\circ} \mathrm{C}\right)$ & Úmido \\
\hline & & $<4 \mathrm{~g} / \mathrm{kg}$ & Seco \\
\hline \multirow{2}{*}{$>30^{\circ} \mathrm{C}$} & \multirow{2}{*}{ Muito quente } & $>186 \mathrm{~g} / \mathrm{kg}$ & Úmido \\
\hline & & $<14 \mathrm{~g} / \mathrm{hg}$ & Seco \\
\hline
\end{tabular}

Quadro 05: Exemplos de diagnóstico de microclima em função da influência da umidade. Fonte: adaptado GRET, 1986.

Combinando os diagnósticos de temperatura e umidade é possível gerar definições de clima como temperado úmido, quente seco, etc. Os resultados servirão de base para escolha das estratégias mais adequadas.

De acordo com ProcelEdifica (2011) quanto aos ventos, em caso de ausência de dados, colhem-se dados verbais de pessoas que habitam o local, observa-se o terreno com uma bússola e a tabela de Beaufort, em horas, dias e estações diferentes, podem, pela simples observação dos fenômenos ocorrentes, dar uma noção da velocidade e direção dos ventos; informando sobre o tipo de abertura e esquadria necessária ao pleno aproveitamento deste recurso natural. 


\subsubsection{Sistemas de Climazização Predial}

O objetivo dos sistemas de climatização é promover condições térmicas e de qualidade do ar aceitável para o ser humano. Existe um enorme conjunto de opções possíveis para efetuar a climatização em edificações. Os sistemas de climatização de uso mais comum em edificações são os de ventilação mecânica, de aquecimento e de refrigeração.

Nos ambientes protegidos, a elevação de temperatura do ar é o principal problema de manejo em regiões de climas tropicais e subtropicais quentes. A redução de temperatura é fundamental para se obter um bom controle do clima que favoreça o desempenho das atividades pessoais e condições agradáveis de trabalho.

Convém lembrar que para minimizar o consumo de energia nas instalações de climatização, o primeiro instrumento é o edifício. Igualmente, é muito importante, que as instalações respondam a zonas determinadas em cada edifício, segundo as orientações, usos e horas de utilização. De ambos os fatores - edifício e instalações - pode-se conseguir uma grande percentagem de economia energética.

\section{Ventilação natural}

A redução da temperatura do ar excessivamente elevada pode ser feita pela ventilação natural, que depende basicamente da diferença de pressão entre o ar localizado no interior e no exterior do ambiente (FROTA, 2001).

A ventilação é uma estratégia de resfriamento, de perda de calor de um ambiente através da renovação do ar, permitindo aos ocupantes de um espaço atingir a sensação de conforto, através do aumento das trocas por convecção na superfície do corpo. 
A avaliação do desempenho da ventilação natural é uma tarefa complexa, pois lida com um fenômeno que possui um comportamento extremamente variável: o vento, o ar em movimento. O vento apresenta velocidade e direção que não são constantes, além de estar sujeito a interferências que também devem ser consideradas pelo projetista, embora seja difícil quantificar com precisão o efeito das mesmas. Um exemplo disso é a influência do entorno edificado, que altera tanto a direção quanto a velocidade do vento que incide na edificação: distribuição espacial dos edifícios e altura dos mesmos, inclinações de beirais e telhados, existência de cercas e muros e a presença da vegetação (BITTENCOURT, 1993).

GIVONI (1991) classifica a ventilação segundo duas espécies distintas: a primeira, chamada de Ventilação de Conforto, obtida pelo aumento da velocidade do ar interno, com a entrada de ventos pelas janelas. Esta atua de forma direta sobre o conforto humano e caracteriza-se pela ventilação diária efetiva, completamente aberta ao meio externo, podendo ser obtida por ventilação cruzada, desde que os ventos apresentem condições aceitáveis de temperatura e umidade; a segunda, denominada de Resfriamento Convectivo Noturno, que é responsável indiretamente pela promoção de conforto, ocorre pelo resfriamento da massa da edificação pela ventilação noturna. O efeito estende-se ao dia seguinte, quando a massa resfriada retarda a entrada de calor para dentro da edificação, com achatamento do aumento da temperatura interna.

Essas duas formas de ventilação apresentam aplicabilidades diversas segundo os diferentes climas, sendo que a eficiência de cada uma varia conforme a amplitude térmica existente.

Segundo o mesmo autor, a aplicabilidade da ventilação de conforto, destina-se principalmente a regiões ou estações que apresentem uma temperatura-limite máxima entre 28 a $32^{\circ} \mathrm{C}$ e uma amplitude térmica pequena, menor que $10^{\circ} \mathrm{C}$, condições próprias apresentadas por climas quentes e úmidos, que não são aptos para reduzir intensamente a temperatura interna em relação à externa. Porém, mesmo considerando uma edificação que apresente 
massa pesada, fechada ao ambiente externo, com paredes de alta resistência térmica, há a necessidade primordial de ventilação diária efetiva, para obtenção do conforto fisiológico, ao favorecer a perda de calor convectivo do corpo (GIVONI, 1991).

A climatização natural define como estratégia principal para climas quentes e úmidos, a ventilação cruzada, que é obtida através da circulação de ar pelos ambientes da edificação. Isto significa que se o ambiente tem janelas em apenas uma fachada, a porta deveria ser mantida aberta para permitir a ventilação cruzada.

Também se deve atentar para os ventos predominantes da região e para o entorno, pois este pode alterar significativamente a direção dos ventos.

\section{Ventilação artificial}

Quando a ventilação natural não é suficiente para promover o conforto térmico dos usuários e a renovação do ar contaminado, é necessária a inclusão de climatização artificial.

\section{-Ventilação mecânica}

Este tipo de ventilação apresenta a vantagem de ajuste e regulação de taxas de ventilação e renovação de ar, com a ajuda de equipamentos que forçam a exaustão do ar e o lançam ao exterior, podendo ser basicamente de dois tipos: ventiladores e exaustores. Esses equipamentos precisam de energia elétrica para seu funcionamento, pelo que é preciso usá-los racionalmente, evitando o desperdício de energia.

A ventilação mecânica pode ser feita com ventiladores móveis, de teto, ou nas paredes exteriores e entradas de ar bem distribuídas. Esses sistemas, em vez de arrefecer o ar, põem-no em movimento, provocando correntes de ar que atuam como refrigeradores da pele, introduzindo ar fresco do exterior e ajudando a movimentar o ar quente. Isto acontece porque a convecção criada pelo ventilador ajuda a evaporação do suor e a remoção de calor da pele, aumentando a sensação de conforto do usuário. 
Podem funcionar também como exaustores, afastando insetos e fumaça. A extração localizada é um outro tipo de ventilação; o objetivo é captar fumaças, poeiras, vapores, etc., o mais perto possível do ponto de geração, evitando sua dispersão no ambiente. É um dos métodos de controle da contaminação dos postos de trabalho mais utilizados, pela relativa facilidade de instalação e eficácia do controle, se o sistema de extração localizada for bem construído e tiver boa manutenção. Os exaustores criam uma pressão negativa que suga o ar quente ou impuro, arremessando-o para fora do ambiente.

\section{Condicionamento de ar}

Consiste em tratar o ar de um local para conseguir condições de temperatura e umidade adequadas, com independência das condições climatológicas externas. Este tipo de climatização deve dar aos locais um ambiente de temperatura confortável, sem cheiro desagradável, nem vapor d'água em quantidades prejudiciais, gases nocivos, escassez de oxigênio, etc. Os sistemas de ar condicionado são usados para aquecer ou resfriar um ambiente, segundo as necessidades da edificação.

\section{-Aquecimento artificial}

A gama de aquecedores artificiais é diversa. Os sistemas mais simples são de aquecimento local, ou direto, utilizando diversas fontes como eletricidade, gás, óleo ou combustíveis sólidos. O mais usado é o aquecedor elétrico, que emite calor por convecção e por radiação; é mais difundido pela facilidade de instalação, baixo custo de transporte e manuseabilidade. Os mais disponíveis no mercado são: radiador incandescente, painel radiador de baixa temperatura, conversor elétrico, bomba de calor (ar condicionado de janela) e o aquecedor central. No entanto, esse sistema de climatização artificial não será maior detalhado, pois a localização da edificação fica salva, segundo a zona bioclimática 6 da NBR 15220, desse tipo de correção de climatização interna. 


\section{-Resfriamento artificial}

É um dos sistemas mais empregados hoje em dia, no Brasil, principalmente em edificações públicas e comerciais. Consiste em controlar simultaneamente a temperatura, umidade, pureza e distribuição do ar, tornando-o compatível com as necessidades dos usuários. Dependendo do tipo, podem ser utilizados para refrigerar e aquecer (ciclo reverso), ou apenas para refrigerar. Os mais utilizados são:

$>$ Ar condicionado de janela - É o aparelho mais simples e compacto, pois possui o condensador e evaporador sob o mesmo invólucro. Deve ser instalado em uma parede voltada para o exterior, buscando uniformizar a temperatura interna do ambiente. $\mathrm{O}$ ar usado pode ser uma mistura com o ar interno ou ser totalmente puxado do exterior, tratado e entregue imediatamente ao interior. Apesar da flexibilidade para mudanças de posição e remanejamento, apresenta um alto nível de ruído e altera o fator estético pela situação nas fachadas.

> Minicentrais de pequeno porte - É uma opção mais sofisticada em relação ao tipo de janela. Este sistema possui unidades evaporadoras e condensadoras separadas de distancia até de 30 metros entre si, pelo que pode atender espaços sem paredes voltadas para o exterior. Apresenta vantagens como o baixo nível de ruído e a possibilidade de condicionar espaços sem paredes externas. Contudo apresenta as desvantagens de custo elevado e dificuldades de manutenção, pois requer profissional especializado.

"Multisplit" - Tem capacidade de refrigeração bem superior às minicentrais de pequeno porte e é o equipamento de menor porte projetado para trabalhar de forma ambiente ou por dutos, pelo que climatiza vários ambientes simultaneamente, mas apresenta a desvantagem de possuir um único termostato, implicando em variações de temperatura segundo a variação de carga de um único ponto. 
Existem outros aparelhos orientados para rede de dutos e ambientes mais complexos, como o "Self-Contained", "Chiller" e "Fan-coil". Geralmente os sistemas de ar condicionado possuem uma participação expressiva no consumo de energia elétrica das edificações e apresentam potenciais de conservação de energia elétrica consideráveis, conseqüência de projetos mal dimensionados, aquisição de equipamentos inadequados e falta de programas regulares de manutenção (ALVAREZ, 1998).

\subsubsection{Sistemas de Iluminação Predial}

Os sistemas de iluminação são os que apresentam o maior número de medidas para conservação de energia de fácil aplicação. A evolução das técnicas de projeto e instalação, acompanhada do surgimento de novos equipamentos, com destaque especial aos novos tipos de lâmpadas eficientes, reatores eletrônicos e luminárias de alta eficiência, oferece uma considerável gama de alternativas para o alcance da eficiencia energética (PROCEL, 2001).

A economia obtida não se restringe apenas à economia proporcionada pela eficientização do sistema de iluminação, mas abrange também a redução da carga térmica em ambientes climatizados.

Em instalações já existentes, podem ser introduzidas alterações nos sistemas de comando, de modo a modular o uso da iluminação de acordo com as necessidades. Em novas construções, podem-se introduzir modernas técnicas de arquitetura e construção que reduzam os requerimentos energéticos para iluminação. Os projetos de iluminação devem considerar os índices mínimos de iluminamento definidos na norma NBR 5413 da Associação Brasileira de Normas Técnicas - ABNT, de modo a manter o conforto e a segurança dos usuários. No Brasil, aproximadamente $24 \%$ da energia elétrica consumida é destinada à iluminação conforme mostrado no gráfico 01 (PROCEL, 2011). Tais valores, aliados ao fato de tecnologias de 
iluminação ineficientes ainda serem largamente empregadas, indicam a existência de um grande potencial de redução do desperdício.
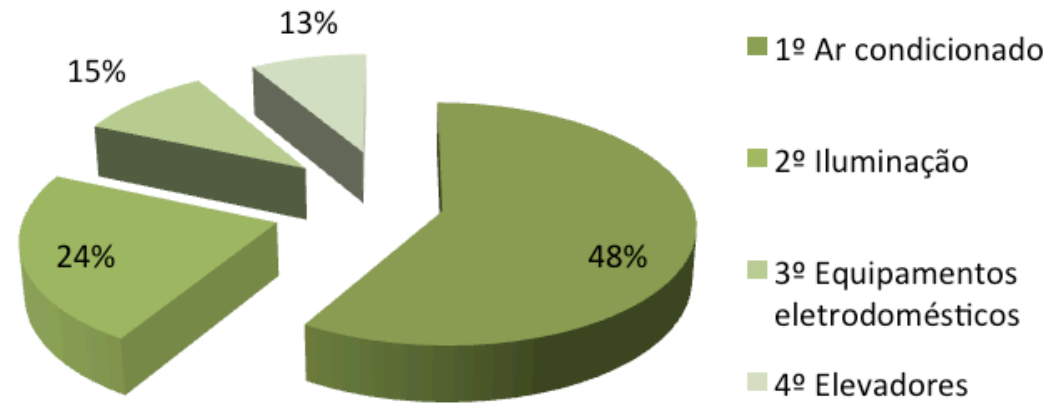

Gráfico 01: Divisão do consumo de energia.

Fonte: Procel, 2011.

Em uma residência a divisão do consumo de energia elétrica é um pouco diferente, de acordo com o gráfico 02 .

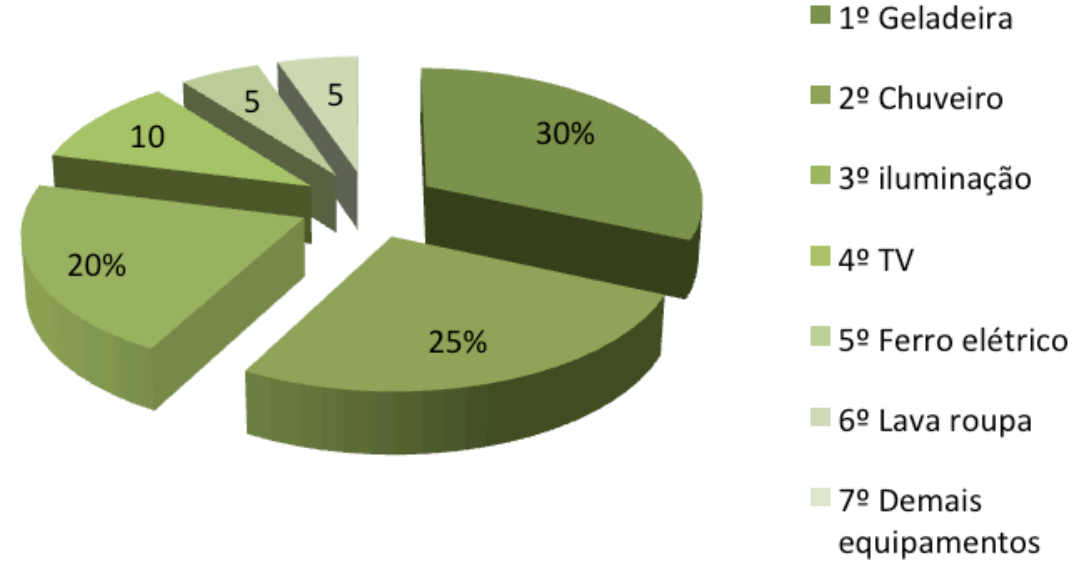

Gráfico 02. Uso Residencial da Energia Elétrica.

Fonte: Goldemberg, 1998.

Existem duas formas básicas de iluminação: Natural - Quando existe o aproveitamento direto (incidência) ou indireto (reflexo/dispersão) da luz solar. Artificial - Quando é utilizado um 
sistema de iluminação (sistema elétrico) que pode ser de dois tipos: geral, para se obter a iluminação de todo o recinto, e suplementar ou focada, para reforçar a iluminação de uma superfície ou tarefa.

A iluminação natural é um dos parâmetros mais importantes a serem levados em conta na arquitetura. Uma vez que é inseparável da prática do bom projeto arquitetônico, iluminar por meios naturais, tem sido considerado como um dos anacronismos do início do século XX, quando a luz elétrica se tornou acessível, tanto prática como economicamente.

Instantânea, segura, previsível e absoluta, a iluminação artificial tem tendido a subjugar o projeto da edificação desde a revolução industrial. A eletricidade tem também possibilitado níveis de iluminação constantes, mas que não refletem os ritmos naturais e as variações imprevisíveis de cada novo dia. Por sua vez, a iluminação artificial é um dos sistemas que mais consome energia no ambiente construído. Desse modo, a recente escalada dos custos energéticos e a crescente preocupação com a manutenção dos recursos naturais têm reacendido habilidades de projeto que envolvem enfoques bioclimáticos.

Uma iluminação inadequada também pode causar desconforto e fadiga visual, dor de cabeça, ofuscamento, redução da eficiência visual ou mesmo acidentes. Uma boa iluminação aumenta a produtividade, gera um ambiente mais prazeroso e pode também salvar vidas.

\section{Iluminação natural}

Um sistema de iluminação natural pode ser entendido como uma série de componentes agrupados numa edificação para admissão da luz natural. As soluções mais utilizadas em edificações são o uso de clarabóias, coberturas dente de serra, coberturas translúcidas, cúpulas, dutos de sol, estufas, fachadas cortina, fachadas translúcidas, galerias, janelas, janelas de cobertura, lanternins, membranas, pátios, poços de luz, sacadas e varandas (LAMBERTZ, 1997). 
A utilização desses recursos pode contribuir significativamente para a redução do consumo de energia elétrica, em virtude da substituição da luz artificial durante o dia, além de melhorar o conforto visual e o bem-estar dos ocupantes. No entanto, o nível de iluminação global e a distribuição desta pelos ambientes devem ser cuidadosamente estudados de maneira a evitar grandes contrastes de níveis de iluminação e o ofuscamento. Além disso, um sistema de iluminação natural deve prever o controle do equilíbrio entre as transmissões de calor para o ambiente e a entrada de luz (HOPKINSON,1966).

Um bom sistema de iluminação natural depende também, de um conjunto de fatores que devem ser considerados desde as fases iniciais do projeto, tais como: disponibilidade de luz natural, obstruções externas, tamanho, orientação, posição e detalhes dos projetos das aberturas, tipos de vidros, tamanho e geometria do ambiente, e grau de reflexibilidade das superfícies internas.

\section{Iluminação artificial}

A eficiência do sistema de iluminação artificial adotado depende do desempenho particular de todos os elementos envolvidos, como lâmpadas, luminárias, reatores e outros, bem como da integração feita com o sistema de iluminação natural. Avanços tecnológicos, principalmente relacionados aos reatores eletrônicos de alto desempenho e às lâmpadas fluorescentes compactas, têm incorporado melhor eficiência aos componentes dos sistemas de iluminação.

Atualmente existem diferentes tipos de lâmpadas para as mais diversas aplicações. Para uso em edificações residenciais e comerciais, no entanto, as lâmpadas elétricas podem ser classificadas em dois grupos básicos: Irradiação por efeito elétrico (incandescentes); e descarga em gases e vapores (fluorescentes, vapor de mercúrio, de sódio, etc.).

As lâmpadas incandescentes são as mais comuns. Embora de vida útil bastante curta, seu custo inicial é baixo. Seu princípio de funcionamento é produzir luz pela elevação da 
temperatura de um filamento, geralmente de tungstênio, ao ser submetido à corrente elétrica. $O$ tamanho reduzido, a possibilidade de dimerização, o funcionamento imediato e a desnecessidade de aparelhagem auxiliar (exceto nas lâmpadas alógenas) são algumas das principais vantagens desse tipo de lâmpada. Em contrapartida, a sua eficiência luminosa é bem mais baixa. Existe uma elevada dissipação de calor, que se traduz no desperdício de energia. Além disso, deve-se tomar cuidado com a possibilidade de ofuscamento, resultante de sua alta luminância. Empregam-se, em edificações residenciais e comerciais, basicamente três tipos de lâmpadas incandescentes: incandescente comum, refletora (espelhada) e alógena (VIANNA, 2001).

As lâmpadas de descarga de gás usadas em edificações comerciais e residenciais são, basicamente, as lâmpadas fluorescentes comuns, as compactas e as de vapor de mercúrio. O filamento não existe nas lâmpadas de descarga de gás. A luz é produzida pela excitação de um gás (devida à passagem de energia elétrica) contido entre dois eletrodos. Dessa forma é produzida radiação ultravioleta (invisível), que, ao atingir as paredes internas do bulbo, revestidas por substâncias fluorescentes (como os cristais de fósforos), é transformada em luz visível. Devido ao seu princípio de funcionamento, as lâmpadas de descarga de gás requerem alguns dispositivos auxiliares, como reatores e "starters" (VIANNA, 2001).

Atualmente, a qualidade do gás e do revestimento no interior das lâmpadas tem sido aprimorada, proporcionando grande melhoria na reprodução das cores e na redução do tamanho das lâmpadas. Produtos relativamente novos, como o "heater cutout" para reatores magnéticos, que desliga o circuito aquecido depois que a lâmpada liga, e os reatores eletrônicos de alta frequência, são dispositivos encontrados no mercado, além de serem uma técnica eficiente de economia de energia.

Dependendo do tipo de ambiente a ser iluminado, é indicado um tipo de lâmpada, isto está relacionado com a eficiência luminosa, índice de reprodução das cores, da temperatura de cor das lâmpadas (LAMBERTZ, 1997). 
Com relação às lâmpadas fluorescentes, outro elemento importante é o reator. Esse componente consome uma parcela significativa de energia por aquecimento. Basicamente, existem três modelos no mercado: o reator convencional, o reator de partida rápida e o reator eletrônico. O modelo convencional é utilizado para apenas uma lâmpada e exige um dispositivo auxiliar para o acendimento da lâmpada (interruptor auxiliar ou "starter"). O reator de partida rápida (um pouco mais econômico do que o convencional) pode acender até duas lâmpadas e não necessita de equipamento auxiliar para partida.

Uma parte importante a ser estudada é o tipo de luminária, isto se explica pelo fato de uma parte da luz emitida pela lâmpada ser absorvida pela luminária, enquanto o restante é emitido ao espaço. A luminária pode modificar o fluxo luminoso emitido pelas lâmpadas, desviálo para certas direções (defletores), ou reduzir a quantidade de luz em certas direções para diminuir o ofuscamento.

De acordo com a norma da ABNT 5413, cada ambiente requer um determinado nível de iluminância ideal, estabelecido de acordo com as atividades a serem ali desenvolvidas. Uma vez conhecido o nível de iluminância, pode-se fazer o cálculo luminotécnico para determinação do número de luminárias necessárias para obtenção das condições adequadas de iluminação do ambiente. Inicialmente, é preciso identificar as características do ambiente (comprimento, largura, pé-direito e altura do plano de trabalho), além das cores e tipos de materiais empregados na construção, já que cada um apresenta um grau de reflexão (parte do fluxo luminoso que retorna ao ambiente) diferente, e que também deverão ser considerados.

Hoje já temos a terceira geração das lâmpadas, os LEDS (diodo emissor de luz) que economizam drasticamente o consumo de energia, além de utilizarem de $1 \mathrm{~W}$ a $5 \mathrm{~W}$ de potência. Porém aspectos que levamos em consideração, para se fazer um projeto luminotécnico de alta precisão, levando em conta como por exemplo, índice de reprodução de cor e temperatura de cor, são ocultados pelos fabricantes de LED, são poucas as embalagens e avisos sobre esses dados. 


\subsection{EnERGIA ELÉGRICA EO EDIFICAÇÕES}

\subsubsection{Energia e Oundo}

O consumo de energia tem aumentado no mundo todo, devido ao modo de vida e as crescentes exigências da população, já que nas edificações procura-se cada vez mais conforto através de sistemas e equipamentos supridos com energia proveniente de fontes renováveis ou não. Desta forma países mais desenvolvidos, como Estados Unidos e Canadá, com alta renda per capita entre sua população, um elevado nível de consumo e com edificações condicionadas artificialmente apresentam um dos maiores consumos de energia elétrica per capita no mundo.

Para piorar a situação, o consumo de energia elétrica quase que total do hemisfério norte (maioria dos países desenvolvidos) provem de termoelétricas. O petróleo é um elemento de influência nas relações geopolíticas contemporâneas, desde quando se tornou a matriz energética básica da sociedade industrial e o elemento fundamental para o funcionamento da economia moderna (BARROS, 2007). Porém, com sua iminente esgotabilidade, além dos graves danos gerados ao ambiente quando utilizado, todas as tecnologias energéticas estão hoje unidas nos países desenvolvidos para suprir sua ausência, bem como controlar a concentração de dióxido de carbono na atmosfera terrestre.

O aquecimento global e as catástrofes climáticas agora são reconhecidos pelos cientistas como consequências do aumento do efeito estufa (IPCC, 2007). O efeito estufa, por sua vez, é consequência em grande parte da emissão de gases poluentes pelas fontes convencionais de energia baseadas em combustíveis fósseis.

De acordo com Matos (2012) sua literatura contem dados demonstrando que ainda é significativo o número de pessoas sem acesso a energia elétrica no mundo. De acordo com a International Energy Agency (IEA), este número em 2010 superava 1,3 bilhão de habitantes, o correspondente a aproximadamente $20 \%$ da população mundial, sendo a maior parte vivendo 
em países em desenvolvimento. A estimativa da IEA para 2030 é que 1 bilhão de pessoas ainda estarão sem eletricidade, 650 milhões na Ásia; pela projeção, a América Latina já terá acesso universal, enquanto que na África o número de pessoas sem luz elétrica tende a aumentar.

Em relação ao Brasil, a pesquisadora levantou que o serviço ainda não contempla toda a população, devido principalmente à sua extensão de 851 milhões de hectares e à própria forma de ocupação do território ao longo do tempo. As famílias excluídas encontram-se majoritariamente nas localidades de menor Índice de Desenvolvimento Humano (IDH): 80\% delas estão no meio rural e $90 \%$ têm renda inferior a três salários mínimos, segundo os dados do programa Luz para Todos (LPT) referentes a 2010.

A autora da tese observa que, além disso, as residências do LPT normalmente ficam em lugares de difícil acesso, o que impacta no valor da tarifa de energia elétrica. Para minimizar os custos, o LPT é financiado pela Conta de Desenvolvimento Energético (CDE), pela Reserva Global de Reversão (RGR) e pela Conta de Consumo de Combustíveis (CCC) - a última com o objetivo de ressarcir parte do custo total de geração de energia elétrica em sistemas isolados. A CCC é proveniente de cotas arrecadadas por empresas distribuidoras, permissionárias e transmissoras a partir de valores pré-determinados pela Aneel.

A busca por fontes renováveis de energia vem ganhando cada vez mais espaço no mercado mundial, onde além de evitar as emissões de gases poluentes provenientes das fontes térmicas convencionais de energia, essas fontes alternativas diversificam a matriz energética. Segundo o BEN (Balanço Energético Nacional) 2011 (ano base 2010), a oferta mundial de energia em 2010 foi composta por $34,4 \%$ de petróleo e seus derivados. A energia hidráulica e a eletricidade representaram apenas $2,2 \%$ do total de energia ofertada no mundo. A oferta mundial de energia por fonte está apresentada no gráfico 03. 


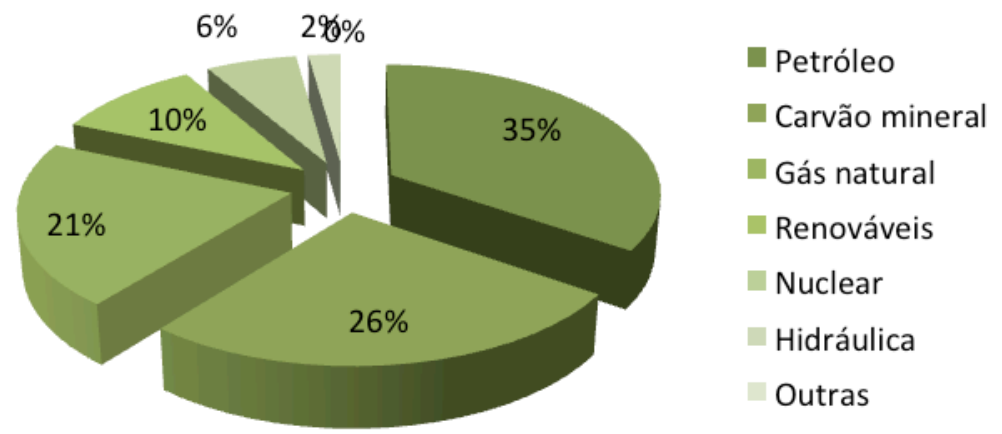

Gráfico 03: Oferta mundial de energia por fonte.

Fonte: BEN, 2011.

A geração de energia elétrica mundial foi de $20.201,8$ TWh no ano de 2010 . Dentro da energia elétrica, o maior percentual de geração mundial por fonte foi devido a centrais a carvão mineral, com $41 \%$ do total. Em seguida aparecem as centrais a gás natural, com $20,1 \%$, as centrais hidroelétricas, com $16 \%$ e as centrais de fonte nuclear, com $14,8 \%$. Os derivados de petróleo representam apenas 5,8\% (BRASIL, 2010).

Pode-se perceber que a participação do carvão mineral teve um crescimento enquanto a participação da fonte hidráulica teve uma redução, quando comparados os anos de 1973 e 2010 . O consumo mundial de energia primária cresceu $1,4 \%$ em 2009 , em relação ao ano anterior, menos do que os $2,4 \%$ de aumento verificado em 2008, sendo o menor crescimento desde 2001. O consumo energético mundial totalizou 11.294,9 Mtep (BEM,). O quadro 06 apresenta os valores de consumo energético mundial por fonte para o ano de 2010, de acordo com dados do BP Statistical Review de Junho de 2011.

\begin{tabular}{|c|c|c|c|c|c|c|}
\hline Mtep & Petróleo & Gás & Carvão & Nuclear & Hidro & Total \\
\cline { 2 - 8 } & 3927 & 2726 & 3303 & 619 & 717 & 11294 \\
\hline$\%$ & 34,77 & 24,14 & 29,24 & 5,49 & 6,36 & 100 \\
\hline
\end{tabular}

Quadro 06: Consumo mundial de energia por fonte.

Fonte: BP, 2011. 
Como se pode notar, o consumo de petróleo lidera com moderada margem acima de outras fontes de energia mais convencionais. O petróleo como já dito, é um combustível fóssil finito que causa poluição. A busca por novas fontes de energia limpa e renovável é urgente para a troca dessa matriz energética.

\subsubsection{Energia Elétrica no Brasil}

Ao contrário da maioria dos países, a matriz energética elétrica brasileira baseia-se, principalmente, em fontes renováveis. O Brasil possui a maior bacia hidrográfica do mundo, com um potencial de geração de energia elétrica incomparável.

A partir da década de 50, as usinas hidrelétricas proliferaram, dando sustentação ao forte impulso do país rumo à industrialização e ao desenvolvimento. Por muitos anos, o Brasil conviveu com a impressão de que suas fontes energéticas hidrológicas eram inesgotáveis. No entanto, a crise energética brasileira, especialmente a primeira ocorrida no ano de 2001, mostrou que ela foi decorrente não apenas dos períodos de secas, mas também da falta de investimentos na construção de novas usinas hidrelétricas e linhas de transmissão. Em novembro de 2008, as usinas hidrelétricas, independentemente de seu porte, respondiam por $75,68 \%$ da potência total instalada no país, que é de 104 GW (ANEEL, 2008). No entanto, o potencial hidráulico é ainda maior, pois o Brasil utiliza apenas 30\% (ANEEL, 2008).

Com o aumento das restrições ambientais e o aumento das distâncias entre os centros urbanos e as bacias com potencial para geração hidráulica, subiram significativamente os custos de implantação de novas usinas geradoras. Além do potencial hidráulico, o Brasil possui ainda uma grande diversidade na oferta de energia que pode ser observada no gráfico 04. 


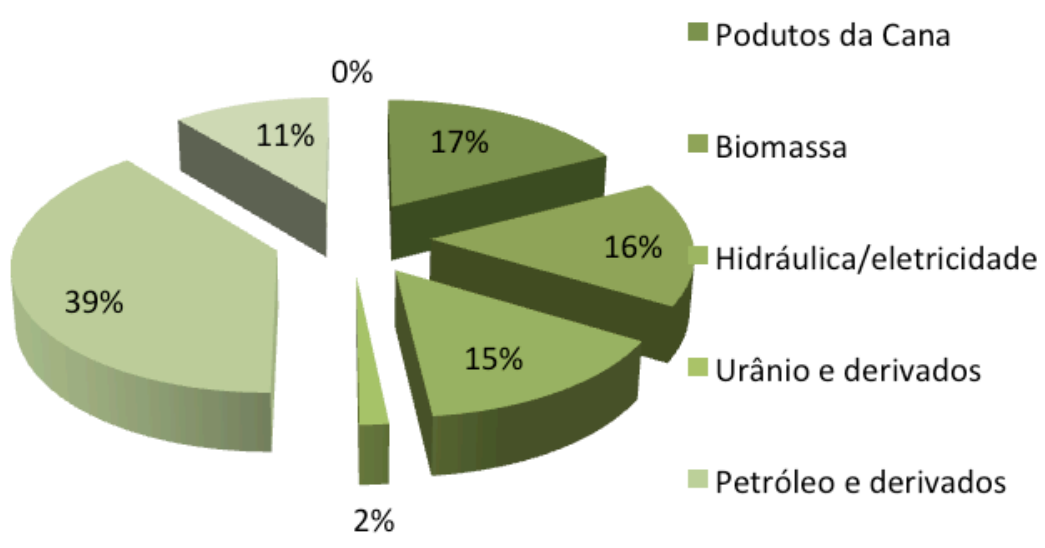

Gráfico 04: Oferta da energia por fontes no Brasil.

Fonte: ANEEL, 2011.

O Brasil mantém vantagens comparativas com o resto do mundo em termos de utilização de fontes renováveis de energia. Em 2008, 45,3\% da OIE foi de energia renovável (ANEEL, 2008), enquanto a média mundial foi de $12,9 \%$ e nos países da OECD foi de apenas $6,7 \%$ (valores de 2006), conforme informações da International Energy Agency.

Dentre as fontes renováveis, destacam-se os derivados da cana-de-açúcar, com 36,16\% de participação, seguido pela fonte hidráulica, com 30,56\%. O Sol, fonte inesgotável e gratuita, não apresenta um valor expressivo, encaixando-se no gráfico como "Outras renováveis", as quais, juntas, atingem apenas $7,7 \%$. O gráfico 05 apresenta a distribuição da oferta interna de energias renováveis. 


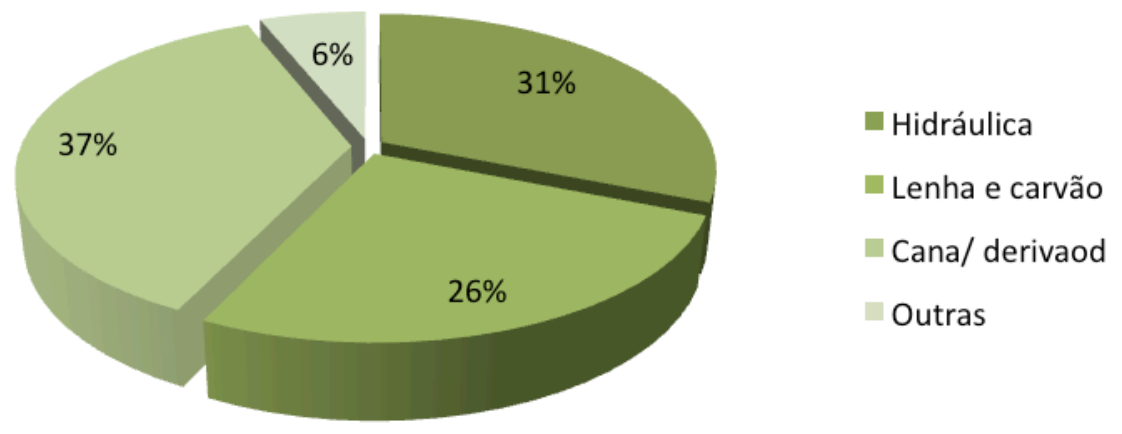

Gráfico 05: Oferta de energias renováveis no Brasil em 2010.

Fonte: BEN, 2011.

Em relação à energia elétrica, $72 \%$ da energia ofertada no Brasil foram provenientes de grandes e pequenas centrais hidroelétricas de acordo com o gráfico 06 abaixo:

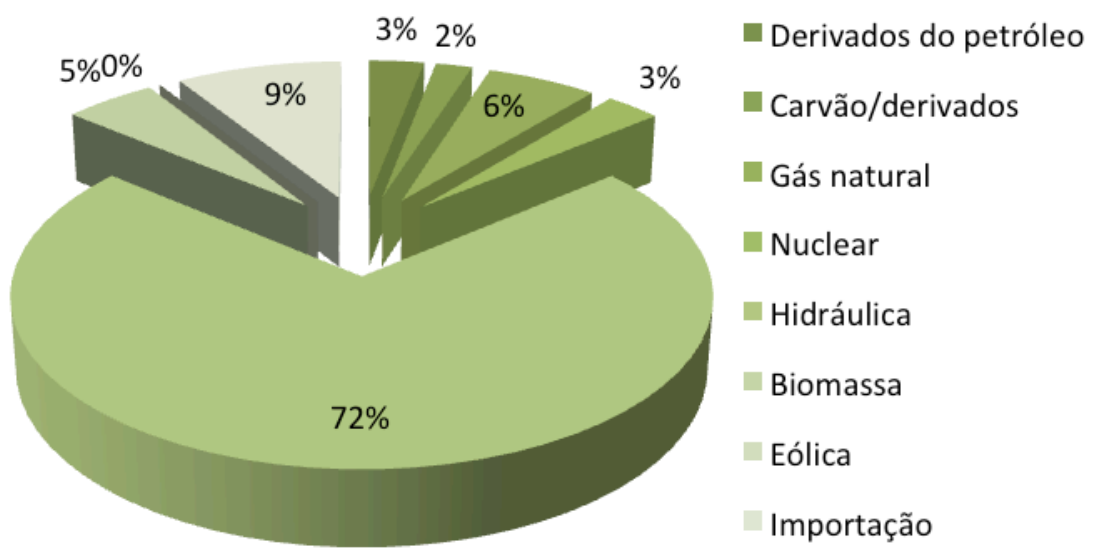

Gráfico 06: Estrutura da oferta interna de energia elétrica de acordo com a fonte de geração no Brasil.

Fonte: BEN, 2011.

A geração de energia elétrica no Brasil, em centrais de serviço público e de autoprodutoras, atingiu 454,5 TWh em 2009 e o consumo final de energia elétrica foi de 428,7 TWh. Houve um crescimento de 5,2\% no consumo energético em relação a 2008. 


\subsubsection{A Política Energética no Brasil}

A política energética no Brasil é um tema importante para este trabalho, pois, está intimamente relacionado aos possíveis usos e benefícios do sistema célula combustivel movida a hidrogênio solar.

O uso de algumas fontes de energia não renováveis tem decaído ao longo do tempo, como é o caso da lenha, enquanto outras de origem renovável tem crescido, como o bagaço de cana e o álcool. Outra fonte não renovável que vem crescendo muito é o gás natural. Mas a maior parte dos combustíveis vem mantendo sua proporção ao longo das décadas, sendo o petróleo o mais expressivo.

O hidrogênio extraído de fontes renováveis é uma alternativa técnica que poderia substituir grande parte da gasolina e do diesel utilizado no setor de transportes em veículos movidos a hidrogênio por meio das células a combustível. O hidrogênio também poderia ser utilizado para o armazenamento de energia em estações de geração hidrelétrica, solar ou eólica, tornando o processo mais eficiente e ajudar a resolver o problema das fontes intermitentes, como solar e eólica. Também poderia fazer uma grande diferença na geração distribuída substituindo os tradicionais geradores a querosene por células a combustível alimentadas com hidrogênio, como proposto neste trabalho (SILVA, 1991).

Entretanto, este não parece ser o caminho que as políticas brasileiras vêm tomando atualmente. Segundo o Plano Decenal de Energia, divulgado pela EPE (Empresa de Pesquisa Energética), serão necessários mais de um trilhão de reais em investimentos para aumentar a capacidade energética até 2020 , cuja demanda deve subir em $60 \%$ até lá. Apesar de prever o aumento das fontes renováveis - em somente 2\% -, a maior parte do total, $67 \%$ (686 bilhões de reais), deve ser aplicado na exploração e produção do petróleo

Enquanto a maior parte dos países envolvidos no Tratado de Kyoto têm desenvolvido políticas para diminuição do uso de fontes fósseis e não renováveis, o Brasil tem caminhado no 
sentido oposto. Talvez a nossa matriz energética, aliado a grandes descobertas de reservas de petróleo recentemente, explique um pouco isso. Cerca de $42 \%$ da matriz energética brasileira é oriunda de fontes renováveis - uma participação expressiva frente aos $15 \%$ da média mundial (BEN, 2010).

Ao contrário do que alguns pesquisadores apontavam na década de 90 (RIFKIN, 2003), há mais petróleo no mundo do que se imaginava. No cenário projetado naquela época, o pico de produção do petróleo (após esse pico seria possível produzir cada vez menos petróleo) seria atingido por volta do ano 2000 , o que levaria a uma crise mundial em curto prazo, já que os preços do petróleo aumentariam após esse momento, pois se demandaria mais petróleo do que seria possível produzir.

Esse cenário ainda é possível, mas hoje em dia essa hipótese é bem menos preocupante devido às descobertas de novas reservas e ao aumento de extração e produção de gás natural. Atualmente se prevê que a relação reserva/produção mundial está num patamar de mais ou menos 40 anos, sendo que esta relação na América do Sul é mais ou menos a mesma (PEREIRA, 2008; PIRES, FERNANDES Y FERNANDES, BUENO, 2006).

Porém, a questão da emissão de Gases de Efeito Estufa antrópicos e o aquecimento global tem se tornado uma questão cada vez mais importante na ciência e na política global, o que tem acelerado a necessidade da substituição de combustíveis fósseis (principalmente o petróleo) por fontes de energia renováveis, independentemente das reservas de petróleo.

\section{As políticas energéticas recentes no Brasil}

Até meados da década de 80 , a Petrobrás e a Eletrobrás eram as principais responsáveis pela prospecção, planejamento da operação e expansão dos setores de petróleo, gás e energia elétrica, sendo que elas mesmas propunham ao Ministério de Minas e Energia as políticas energéticas (CARVALHO, 2005). 
$\mathrm{Na}$ década de 90, o governo FHC (Fernando Henrique Cardoso) criou o Programa Nacional de Desestatização, que privatizou diversas distribuidoras de energia e acabou com o monopólio da Petrobrás. A maior parte das distribuidoras, cerca de $80 \%$, foi privatizado. Mas menos de $20 \%$ da capacidade de geração teve o mesmo fim. O governo separou as atividades de geração, transmissão e distribuição, numa tentativa de dinamizar os três setores e gerar concorrência. Porém, manteve o controle da geração de energia por motivos estratégicos de segurança e controle.

Foi criado em 1996 (após o início das privatizações) uma agência reguladora para o setor elétrico, a ANEEL (Agência Nacional de Energia Elétrica), uma autarquia vinculada ao MME, que ficou responsável por criar regulamentos e fiscalizar as atividades das empresas, tanto públicas quanto privadas, do setor elétrico, além de outra tarefas antes executadas pela Eletrobrás e o MME, como promover licitações, fazer a gestão dos contratos de concessão, fixar os critérios para os cálculos das tarifas, etc.

Também foi criado o ONS (Operador Nacional do Sistema Elétrico), nos mesmos moldes da ANEEL, mas responsável pela operação do SIN (Sistema Interligado Nacional), que administra a geração e transmissão de energia das diversas operadoras interconectadas e garante o abastecimento de energia elétrica em praticamente todo o território nacional.

E para dar continuidade ao processo de privatização e concessão de novas geradoras e operadoras, foi criado o Mercado Atacadista de energia Elétrica (MAE), que por diversas disputas políticas, demorou para entrar em operação, e foi substituída pela Câmara de Comercialização de Energia Elétrica (CCEE), criado em 2004 (CARVALHO, 2005).

Em 1997 foi criado o Conselho Nacional de Política Energética (CNPE), que entrou em operação em 2000. O conselho é formado por sete ministros (o de Minas e Energia; Meio Ambiente; Ciência e Tecnologia; Casa Civil; Fazenda; Planejamento, Orçamento e Gestão; e Desenvolvimento, Indústria e Comércio) além de um representante dos governos estaduais, um 
representante das universidades e um cidadão especialista em política energética (os dois últimos indiciados pelo presidente).

Em 1999, o MME criou o Comitê Coordenador do Planejamento da Expansão dos Sistemas Elétricos (CCPE), responsável por coordenar e elaborar o planejamento da expansão dos sistemas elétricos. Porém, em 2002 uma nova lei substituiria o CCPE pelo Centro de Estudos e Planejamento Energético (CEPEN). No fim, ao invés disso, em 2004 foi criado a Empresa de Pesquisas Energéticas (EPE), uma empresa estatal que substituiu o CEPEN e é hoje responsável pelo planejamento do setor energético e planos de expansão de médio e longo prazo. Todas essas alterações seguidas revelam a desorganização do setor elétrico na época de suas privatizações (CARVALHO, 2005; EPE, 2011).

Houve também a separação contábil das atividades de distribuição e comercialização no varejo; algumas empresas estatais foram separadas em várias companhias no processo de privatização da transmissão e distribuição. Também foram criados novos agentes no mercado, como os produtores independentes e os consumidores livres (que podem escolher seus fornecedores de energia elétrica) (CARVALHO, 2005).

Segundo Carvalho (2005), o governo pode gerir o setor energético utilizando três instrumentos bem distintos e complementares: a formulação de políticas públicas; planejamento, indicativo ou determinativo, conforme as circunstâncias; e regulação dos mercados de energia. Esses instrumentos devem ser utilizados por um governo de forma independente entre si, mas de maneira complementar.

Para que haja uma boa integração destes três instrumentos no país, é necessário que: o Ministério de Minas e Energia (MME) defina com clareza as suas relações com os demais agentes que atuam no setor energético, destacando-se as agências reguladoras e as empresas concessionárias estatais a elas vinculadas e possua um órgão de apoio, que execute de forma eficiente e sustentável um planejamento energético de cunho estrutural para o País; que a atual legislação do setor energético sofra uma revisão com o objetivo de torná-la mais clara, eliminando os pontos conflitantes e vagos de leis, decretos, portarias, protocolos de entendimentos, contratos de gestão, etc.; definição clara dos papéis de cada instituição na gestão do setor e como eles devem relacionar-se entre si de uma forma harmoniosa e eficiente, independente das aptidões de seus dirigentes (Carvalho, 2005). 
Segundo o autor, as políticas energéticas no Brasil foram formuladas no passado de uma forma isolada para cada segmento do setor energético (petróleo, gás natural, eletricidade, etc.) e com pouca relação com outras políticas públicas. Porém, isso está mudando. Desde a instalação do CNPE esses segmentos têm sido planejados de maneira mais articulada entre si e com outras políticas públicas e, através de estudos prospectivos de longo prazo (mais de 20 anos), também pensados em cenários alternativos, com outras políticas, econômicas, energéticas, ambientais, etc. O autor também enfatiza que deve haver uma maior articulação entre as políticas energéticas e ambientais, tratadas até o momento como políticas muitas vezes adversárias.

As políticas energéticas ainda estão fortemente concentradas no âmbito federal. Sua principal proposição é que haja um processo de descentralização das políticas energéticas, que desse maior autonomia aos estados da federação e órgãos a eles associados para planejar e implementar suas políticas energéticas, sem deixar de articulá-las com outros estados e a União (Carvalho, 2005).

O processo de reestruturação do MME sugerido neste trabalho contempla a descentralização das suas atividades em questões que podem ser conduzidas de forma mais eficiente no âmbito estadual, em virtude de uma maior facilidade de articulação entre os agentes envolvidos e um conhecimento mais detalhado das especificidades locais. Dentre estas questões pode-se destacar a elaboração de projeções de matrizes energéticas estaduais, busca de universalização do acesso à energia elétrica, fomento ao uso de recursos energéticos locais, geração distribuída de energia elétrica, e novos programas de eficiência energética (Carvalho, 2005).

O autor também critica a política de preços no Brasil. Os preços dos derivados de petróleo - gasolina, óleos diesel, óleo combustível, GLP, nafta, querosene de aviação e óleo lubrificante - no Brasil tem sido estabelecidas pelas condições do mercado, sem nenhuma regulação, desde janeiro de 2002 até agora, conforme determinam as Leis nos 9.478/97 e 9.990/00 (Carvalho, 2005).

Outro problema relatado por Carvalho (2005) são as poucas e fracas políticas de P\&D em eficiência energética. A promulgação da Lei no 10.295 de 17/10/2001, que possibilita ao governo fixar níveis máximos de consumo energético específico ou níveis mínimos de eficiência energética para equipamentos produzidos no País ou importados, constitui o mais importante 
incentivo, em termos de política energética, nos últimos anos, na busca por níveis mais elevados de eficiência energética no Brasil.

Desde 1998 os contratos de concessão das empresas concessionárias distribuidoras possuem uma cláusula que requer que elas apliquem pelo menos $1 \%$ (o que já é pouco) de sua receita anual em programas de eficiência energética e de P\&D, com pelo menos $0,25 \%$ em programas de gerenciamento pelo lado da demanda e pelo menos $0,1 \%$ em atividades de P\&D. Porém, a lei $n^{\circ} 9.991$, promulgada em julho de 2000 , diminuiu esse valor, estabelecendo que as concessionárias distribuidoras de eletricidade devem aplicar anualmente pelo menos $0,75 \%$ de sua receita operacional líquida em projetos de P\&D (Carvalho, 2005). Segundo os secretários do CENEH, essa lei é o principal incentivo das operadoras de energia a contratarem instituições de pesquisa para desenvolverem pesquisas em eficiência energética. Porém, segundo eles, essas empresas contratam as pesquisas só para não serem multadas pela ANEEL e em praticamente todas as vezes não desenvolvem ou colocam em prática o resultado dessas pesquisas.

Em sua tese de doutorado, a autora Maiana Matos (2012) relembra as várias medidas tomadas pelo governo federal visando levar energia elétrica para toda a população brasileira. A começar pelo Programa de Desenvolvimento Energético dos Estados e Municípios (PRODEEM), criado em 1994 com a finalidade de permitir acesso à eletricidade pelas comunidades isoladas contemplando bombeamento de água e iluminação pública. A maioria dos sistemas do PRODEEM foi instalada em escolas rurais; e a quase totalidade desses sistemas era fotovoltaico, apesar da concepção original de diferentes tipos de fontes renováveis.

O Programa Nacional de Eletrificação Rural (PNER), também conhecido como Luz no Campo, surgiu durante o mandato do presidente Fernando Henrique Cardoso com objetivo similar ao do PRODEEM. Em novembro de 2003, o governo lançou o programa Luz para Todos (LPT), ao qual foi incorporado o Luz no Campo, com a meta de fornecer acesso à energia elétrica para mais de 10 milhões de pessoas no meio rural até 2008.

O LPT foi estendido até 2014 através de decreto, ao se perceber que o universo de excluídos era maior do que se pensava. O programa já atendeu cerca de 3,3 milhões de famílias 
(aproximadamente 15 milhões de pessoas) e pretende contemplar mais 715 mil famílias de 2011 a 2014. No caso do Ceará, em cuja capital a autora da tese realizou o estudo de caso, o Luz para Todos beneficiou 172 mil famílias (862 mil pessoas) no período de 2004 a 2012.

Foi em 2004 que a Aneel publicou resolução regulamentando os procedimentos e as condições de fornecimento através dos sistemas Individuais de Geração de Energia com Fontes Alternativas (SIGFl's) - sistemas que podem ser utilizados como alternativa para universalização dos serviços de eletricidade. Em 2012, outra resolução normativa da Aneel estabeleceu os procedimentos e as condições de fornecimento por meio de Microssistema Isolado de Geração e Distribuição de Energia Elétrica - MIGDI (ANEEL, 2013).

\section{A eletricidade}

Apesar de corresponder a apenas $17 \%$ da matriz energética nacional, o Brasil tem como fonte de geração de eletricidade majoritariamente a hidroeletricidade, uma forma considerada limpa e renovável e em uma das maiores proporções do mundo. Contando com o que é importado da parte paraguaia de Itaipu, cerca de $85 \%$ da eletricidade no Brasil provém de hidrelétricas e uma parte significativa provém da biomassa, ramo que vem crescendo muito ultimamente devido ao aumento da auto produção utilizando bagaço de cana.

A maior parte do potencial hidrelétrico (cerca de 60\%) do Brasil encontra-se na bacia amazônica. Porém, há um grande problema em se instalar novas hidrelétricas nessa região. Um estudo projetivo, comparando as emissões de gases do efeito estuda (GEE) de uma hidrelétrica como Tucuruí (na região da floresta amazônica) com uma usina termelétrica equivalente (1950MW), ao longo de cem anos, chegou à conclusão de que a hidrelétrica emitiria a mesma quantidade de GEE que a termoelétrica, durante 38 anos, devido à decomposição do material orgânico represado (JUNK \& MELLO, 1987). Em outro estudo, se projetou que em apenas 10 
anos, Tucuruí emitiria 171 milhões de toneladas equivalentes de $\mathrm{CO} 2(\mathrm{CO} 2+\mathrm{CH} 4)$ (FEARNSIDE, 1997 Apud: BERMANN, 2001).

A hidroeletricidade é uma grande aliada para um desenvolvimento sustentável e a capacidade hidráulica no Brasil é uma grande riqueza, porém, se não se pensar um código ambiental adequado e regulamentações precisas por parte das instituições regulamentadoras para a instalação e funcionamento dessas hidrelétricas, incluindo a compensação financeira dos atingidos, a implantação de novas hidrelétricas na bacia amazônica pode representar um grande prejuízo ambiental e social ao invés de um desenvolvimento sustentável.

A carência só de eletricidade no país, considerando que todos tivessem acesso a esses bens e ao seu consumo mínimo, seria segundo seus cálculos, de 35 mil TWh em 1999 ou, cerca de $43 \%$ do consumo residencial naquele ano. Isto evidencia a grande carência energética no Brasil e mais especificamente, a desigualdade de acesso a esses bens básicos, já que se consome muito menos do que seria o adequado (BERMANN, 2001).

\section{O problema das bidrelétricas}

O aproveitamento de potenciais hidráulicos para a geração de energia elétrica requer, muitas vezes, a formação de grandes reservatórios e, consequentemente, a inundação de grandes áreas. Na maioria dos casos, trata-se de áreas produtivas e/ou de grande diversidade biológica, o que exige, previamente, a realocação de grandes contingentes de pessoas e animais silvestres.

A formação de reservatórios de acumulação de água e regularização de vazões, por sua vez, provoca alterações no regime das águas e a formação de microclimas, favorecendo certas espécies (não necessariamente as mais importantes) e prejudicando ou até mesmo extinguindo outras. Entre as espécies nocivas à saúde humana, destacam-se parasitas e transmissores de doenças endêmicas, como a malária e a esquistossomose. 
Das distantes hidrelétricas até as cidades, a energia é conduzida por linhas de alta tensão suspensos por torres de transmissão. A área das bitolas dos cabos é proporcional à potência elétrica transmitida. Se todos os equipamentos e máquinas forem ligados ao mesmo instante em uma cidade, a potência demandada poderá ser maior do que a transmissível, causando a queda do sistema. Daí, a necessidade de se evitar os picos de demanda e distribuíla da forma mais uniforme possível ao longo do dia. A tarifação horo-sazonal foi uma medida do governo com o objetivo de tornar a curva de carga dos consumidores e, consequentemente, do sistema elétrico, mais uniforme ao longo do dia (PROCEL EDIFICA, 2011).

Dois exemplos internacionais de graves problemas decorrentes de empreendimentos hidrelétricos são Akossombo (Gana) e Assuam (Egito). Além de alterações de ordem hídrica e biológica, esses projetos provocaram o aumento da prevalência da esquistossomose mansônica, que em ambos os casos ultrapassou o índice de $70 \%$ da população local e circunvizinha, entre outros transtornos de ordem cultural, econômica e social (ANDREAZZI, 1993).

Há também os perigos de rompimento de barragens e outros acidentes correlatos, que podem causar problemas de diversas ordens e dimensões. Um exemplo clássico é o de Macchu, na Índia, onde 2.500 pessoas pereceram, em razão da falha de uma barragem em 1979 (ELETRONUCLEAR, 2001). Por tudo isso é necessário realizar estudos prévios e medidas preventivas a respeito do impacto sócio-ambiental potencial decorrente da implantação de um determinado empreendimento hidrelétrico.

No Brasil, há vários exemplos de grandes impactos socioambientais decorrentes de empreendimentos hidrelétricos, como Tucuruí e Balbina, na Amazônia, e Sobradinho, no Nordeste do País. No momento vivemos uma discussão em torno usina hidrelétrica de Belo Monte, no rio Xingu, Pará, a usina que produzirá menos energia, proporcionalmente à capacidade de produção, e que terá maior custo para os investidores na comparação com outros empreendimentos de grande porte, em razão da intensidade dos impactos sociais e ambientais na região, na avaliação de especialistas na área consultados (GLOBO, 2012). A figura 07 a 


\section{em residências}

seguir mostra uma área urbana que foi inundada para o início das obras de Belo Monte. $\mathrm{Na}$ figura 06 o bairro Invasão dos Padres, em Altamira, que será alagado. Marcio Astrini, da Campanha da Amazônia do Greenpeace, afirma que os estudos de impactos sociais e ambientais apresentados pela construção da hidrelétrica até 0 momento estão subdimensionados.

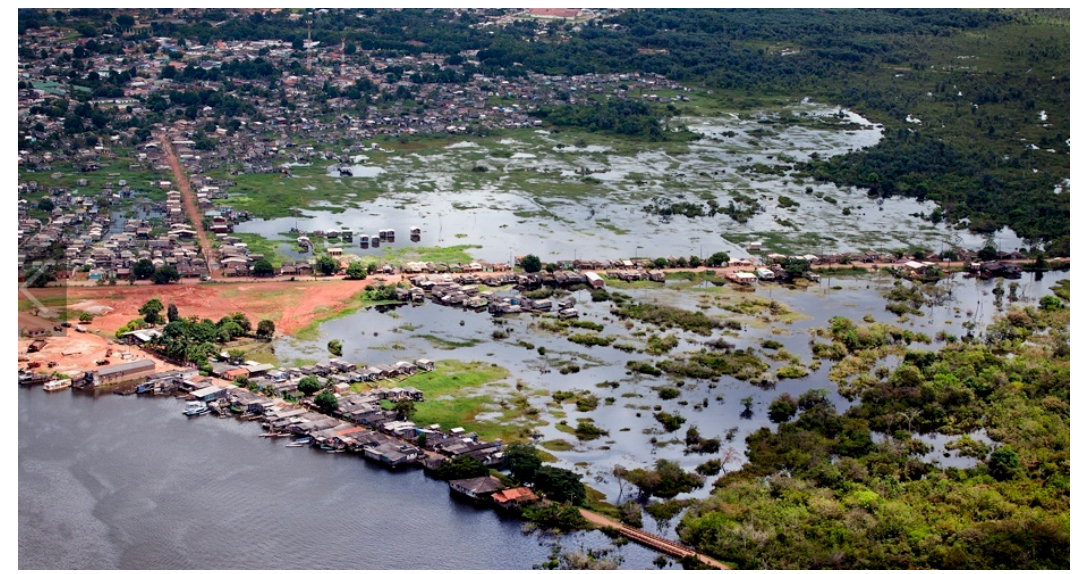

Figura 06: Bairro Invasão dos Padres inundado para instalação da hidrelétrica Belo Monte.

Fonte: http://noticias.uol.com.br/ciencia/album/2012/04/26/greenpeace-sobrevoa-belo-monte-e-mostradestruicao.htm\#fotoNav=10

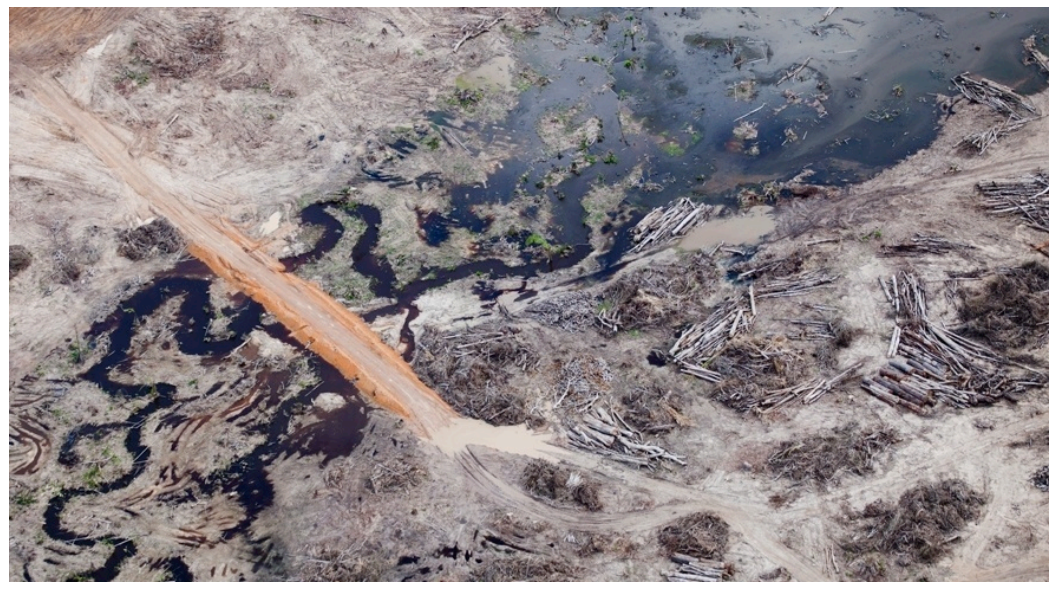

Figura 07: Área inundada para instalação da hidrelétrica Belo Monte.

Fonte: http://noticias.uol.com.br/ciencia/album/2012/04/26/greenpeace-sobrevoa-belo-monte-e-mostradestruicao.htm\#fotoNav=3

As fotos 06 e 07 são obras do canal da usina de Belo Monte, próximo de Altamira. Ela será a terceira maior do mundo e alagará 400 mil hectares. A hidrelétrica deverá entrar em 
operação em 2015 após um investimento de US\$10,6 bilhões e sua capacidade de geração será de no máximo 11.233 megawatts nas épocas de alta do rio Xingu.

Um aspecto particular desse domínio tecnológico refere-se ao problema da transmissão de energia a longas distâncias, que pode ocorrer em termos de corrente alternada (CA) ou contínua (CC). O aproveitamento dos recursos energéticos disponíveis em regiões distantes dos centros consumidores somente é viável economicamente, através do maior domínio tecnológico na área de transmissão.

Fica evidente que o aproveitamento hidroelétrico, apesar de ser uma fonte renovável e limpa, pode produzir impactos ambientais (como afetar a piracema, danos na fauna e flora), sociais (expulsar populações de seus locais de origem) e financeiros, quando mal projetados.

Entretanto, uma possibilidade interessante no caso das hidrelétricas é o armazenamento de energia na forma de hidrogênio. A eletricidade gerada pelas hidrelétricas fora do horário de pico poderia alimentar células eletrolíticas (dispositivo que decompõem a água através de uma corrente elétrica) e gerar hidrogênio a partir da eletrólise da água. Depois de purificado, o hidrogênio pode ser armazenado na forma comprimida ou na forma líquida e reconvertido posteriormente em energia elétrica através de células a combustível ou de turbinas a gás (FERREIRA, 2003).

Além de aproveitar de maneira mais eficiente o potencial energético das hidrelétricas já instaladas, evitando a construção de outras barragens, esse processo poderia gerar um excedente para o mercado de hidrogênio, necessário para as células de combustível. Este processo de produção, assim como outros, tende a se tornar cada vez mais eficientes e baratos. Com a crescente demanda e evolução dessas tecnologias, o armazenamento de energia na forma de hidrogênio em hidrelétricas deve se tornar recorrente em breve, segundo os secretários do CENEH.

O Brasil se mostra muito avançado ambientalmente em relação a outros países, mesmo desenvolvidos, quando o assunto é geração de energia elétrica. Emite-se muito pouco GEE para 
se gerar muita energia elétrica. Porém, a infraestrutura de distribuição elétrica ainda deficiente, com altas taxas de quedas de energia, além do quadro de desigualdade social no país e as altas tarifas cobradas pelas concessionárias em algumas regiões do país, principalmente pobres, ainda são um obstáculo a um efetivo desenvolvimento sustentável (no sentido ambiental e social) nesse setor.

As células eletrolíticas poderiam ajudar nessa questão, convertendo a energia que seria desperdiçada em hidrogênio, para ser utilizada posteriormente em células a combustível. Isso poderia ser utilizado não só em hidrelétricas, mas também em estações eólicas ou solares, que sofrem do mesmo problema da intermitência.

\subsubsection{Conceitos de Energia Distribuída - Autonomia Energética em Edificações}

O sistema elétrico brasileiro experimentou, entre 2001 e início de 2002, uma deficiência significativa de suprimento, colocando o mercado na situação de iminente desabastecimento. Esta situação foi contornada, principalmente, pela ação de consumidores residenciais, comerciais e industriais, que reduziram, aproximadamente, em $20 \%$ a carga da Região Sudeste e Centro Oeste e em 23\% a carga do Nordeste (PAULA, 2004). Uma das alternativas que os consumidores com capacidade de investimento poderiam ter adotado seria a adoção da autoprodução, com a instalação de geradores independentes.

A geração elétrica realizada junto ou próximo ao ponto de consumo, independente da potência, tecnologia e fonte energética, é denominada geração distribuída. As tecnologias de geração distribuída têm evoluído para incluir potências cada vez menores, ou seja, criando miniusinas geradoras. Existem diversas formas de realizar a geração distribuída, tais como: cogeradores, geradores que usam como fonte de energia resíduos combustíveis de processo, geradores de emergência, geradores para operação no horário de ponta, pequenas centrais hidrelétricas e painéis fotovoltaicos (INEE, 2008). 
Uma das principais vantagens da geração distribuída, em comparação com a geração central de energia, é a economia em investimentos para a ampliação da rede, diminuindo perdas por transmissão e distribuição (T\&D) e melhorando a estabilidade do serviço de energia elétrica.

Na primeira metade do século $\mathrm{XX}$, a geração elétrica próxima ao consumidor chegou a ser regra no Brasil, quando a energia industrial era praticamente toda gerada localmente. A partir da década de 40, no entanto, a geração em centrais de grande porte ficou mais barata, reduzindo o interesse dos consumidores pela geração distribuída e, como consequência, o desenvolvimento tecnológico para incentivar esse tipo de geração também parou (INEE, 2008). Em 2004, ocorreu um grande avanço para a geração distribuída, que foi mencionada na Lei 10.848/04 como uma das possíveis fontes de geração de energia. O detalhamento do Decreto 5.136/04 fornece características que ajudarão as empresas distribuidoras, que até então se opunham a esta forma de geração, a enxergarem na geração distribuída uma das formas de mitigar riscos de planejamento.

A geração fotovoltaica distribuída, apesar de causar um menor impacto ao ser injetada na rede elétrica em relação a outras tecnologias como a eólica, possui uma característica tecnológica particular (o fato de necessitar de inversores para converter a corrente primária em CA) que a torna interessante como matéria de pesquisa a ser aprofundada (CAAMAÑO et al., 2007).

Ao longo dos próximos trinta anos, espera-se que o setor elétrico seja completamente reformulado. A rede de distribuição precisará estar preparada para a grande quantidade de energia que será gerada de forma distribuída e a consequente redução na geração energética convencional pelas centrais produtoras. Para que isso seja possível, será necessário que haja uma renovação radical no dimensionamento e no design da rede, bem como no controle e no sistema de operação da mesma.

Como grande parte da energia consumida é proveniente de redes de distribuição em baixa tensão, é crucial a evolução e a otimização destas redes para o momento em que houver o 
aumento das frações de geração distribuída. Neste cenário, a geração distribuída poderá assumir o papel das centrais produtoras convencionais, existindo, definitivamente, a necessidade de rever, e, onde for apropriado, alterar e adaptar as estruturas e os procedimentos que são utilizados hoje em dia (BENDEL et al.; 2005; KOELN e GRABITZ; 2005; KUROKAWA et al.; 2005; NIETSCH et al.; 2007 apud CAAMAÑO et al.; 2007).

No dia 17 de abril de 2012 a ANEEL aprovou regras destinadas a reduzir barreiras para instalação de geração distribuída de pequeno porte, que incluem a microgeração, com até 100 KW de potência, e a minigeração, de 100 KW a 1 MW. A norma cria o Sistema de Compensação de Energia, que permite ao consumidor instalar pequenos geradores em sua unidade consumidora e trocar energia com a distribuidora local. A regra é válida para geradores que utilizem fontes incentivadas de energia (hídrica, solar, biomassa, eólica e cogeração qualificada). Pelo sistema, a unidade geradora instalada em uma residência, por exemplo, produzirá energia e o que não for consumido será injetado no sistema da distribuidora, que utilizará o crédito para abater o consumo dos meses subsequentes. Os créditos poderão ser utilizados em um prazo de 36 meses e as informações estarão na fatura do consumidor, a fim de que ele saiba o saldo de energia e tenha o controle sobre a sua fatura. Os órgãos públicos e as empresas com filiais que optarem por participar do sistema de compensação também poderão utilizar o excedente produzido em uma de suas instalações para reduzir a fatura de outra unidade (ANEEL, 2012).

Para que uma edificação possa ser considerada energeticamente autônoma, é necessário que ela consiga suprir sua demanda energética de forma independente. Essa autonomia pode ser obtida com o uso de fontes de energia renováveis não convencionais. Essas fontes caracterizam-se pela sua recuperação cíclica de forma natural, além de pouco contribuírem para a poluição do meio ambiente.

Dentre as fontes renováveis, destacam-se a solar, a eólica e a biomassa, em função dos resultados do avanço tecnológico, que aumentaram a eficiência dos equipamentos utilizados no aproveitamento desses recursos, tornando-os competitivos, em alguns casos, com os meios convencionais de geração de energia. As edificações que fazem uso desses recursos são 
classificadas de duas formas distintas: as que constituem um sistema isolado e as interligadas à rede da concessionária.

\section{Sistemas isolados}

Sistemas isolados são aqueles que não estão interligados à rede elétrica da concessionária local e, em geral, utilizam alguma forma de armazenamento de energia. Esse armazenamento pode ser feito através de baterias, com o objetivo de utilizar aparelhos elétricos, ou na forma de energia potencial gravitacional, com a finalidade de armazenar a água bombeada em reservatórios para posterior utilização.

Os sistemas que armazenam energia em baterias necessitam de um dispositivo para controlar a carga e a descarga das mesmas. Esse dispositivo tem como principal objetivo não deixar que haja danos à bateria por sobrecarga ou descarga profunda (CRESESB, 1999).

\section{Sistemas interligados à rede}

Neste tipo de sistema, a edificação utiliza a energia produzida pelo o seu próprio sistema para suprir sua demanda energética. Caso a geração exceda a demanda, o excedente passa a ser disponibilizado para a companhia distribuidora de eletricidade. No período onde não há geração de energia, toda a demanda é suprida pela rede elétrica. Dessa forma, o usuário compra uma menor quantidade de energia da rede, diminuindo a carga energética da concessionária. Esses sistemas fornecem, portanto, uma ferramenta a mais para que as concessionárias de energia possam gerir a disponibilidade de energia da sua área de concessão (ZUMARAN, 2000).

Todo o sistema é ligado a inversores para permitir que a energia gerada seja lançada diretamente na rede. Para esse tipo de sistema, onde o consumidor sempre terá a rede elétrica 
da concessionária como garantia de fornecimento ("backup"), o usuário necessita apenas dimensionar o subsistema de acumulação com capacidade reduzida, para fornecer às cargas as tensões e correntes necessárias e garantir o fornecimento energético por um período curto (1 ou 2 horas), em caso de falha da concessionária. No setor urbano, onde se tem essa real possibilidade de interligação do sistema à rede da concessionária, a energia solar é a que melhor se adequa, por se tratar de uma fonte de geração não emissora de ruídos e praticamente não apresentar riscos no processo de operação do sistema. As outras fontes (eólica, biomassa, etc.) ficam mais restritas a aplicações isoladas.

\section{Comunidades isoladas e o acesso à energia elétrica}

O significado da expressão "comunidade isolada" para o setor elétrico brasileiro é simples, visto que não envolve, em princípio, nenhum conceito econômico ou das ciências sociais e sim da engenharia: trata-se da comunidade eletricamente isolada, ou seja, que não está conectada ao sistema elétrico nacional ou ao principal sistema elétrico de um país vizinho, diferenciando-se apenas pelo fato de ser ou não atendido pelos serviços de eletricidade (ROSA, 2007).

Logo, pode tratar-se de uma comunidade isolada atendida ou não-atendida. Se atendida, constitui ou pertence a um "sistema elétrico isolado", ou seja, sistema onde a energia elétrica é gerada e consumida dentro de uma área delimitada, não conectada ao sistema elétrico nacional - uma vila, uma cidade ou até uma região maior.

Os sistemas elétricos isolados brasileiros concentram-se principalmente nos estados da região Norte. Ainda existem muitos desses sistemas no norte do Mato Grosso e poucos em outros estados (ELETROBRÁS, 2004 e 2005). Quando não-atendida, a comunidade se insere na problemática dos "excluídos elétricos", que tem sido tratada pelas políticas públicas, notadamente, a partir da edição da Lei $n^{\circ} 10.438 / 02$, que dispôs, entre outras coisas, sobre a 
universalização do serviço público de energia elétrica, e do Decreto $n^{\circ} 4.873 / 03$, que criou o Programa Luz para Todos.

De acordo com Rocha e Silva (2002), o modelo de oferta de energia implantado nas décadas de 1970 e 1980, que priorizou a geração centralizada de energia, beneficiando as cidades mais importantes da Amazônia gerou também um esquecimento das populações dispersas na área amazônica, com densidades populacionais às vezes menores que $1 \mathrm{hab} / \mathrm{km}^{2}$, mas que no total atingem cerca de vinte milhões de habitantes sem oferta adequada de energia. Em toda a Amazônia Legal, conforme Cruz (2005), a quantidade de domicílios rurais não atendidos poderia chegar a mais de 450 mil, dos quais, estima-se, em torno de dois terços estariam localizados no interior da floresta.

Os critérios para o atendimento às comunidades sem acesso à eletricidade foram, em grande parte, tratados nos diplomas legais supracitados. O programa Luz para Todos priorizou o atendimento à população do meio rural, até o ano de 2008 , tendo em vista que, embora a taxa média de eletrificação brasileira de 93\% (IBGE, 2010) seja muito boa, ante a de outros países, a taxa de atendimento na zona rural ainda é ruim: $70,6 \%$, contra $97,4 \%$ da urbana.

São comunidades em locais muito isolados, com poucas dezenas de casas aglomeradas e, em muitos dos casos na Amazônia, populações ribeirinhas e extrativistas cujas famílias estão distribuídas ao longo do curso de um rio, distantes umas das outras na ordem de quilômetros. Assim, ao elaborarem seus planos de atendimento, as concessionárias têm priorizado comunidades em que seja possível a aplicação de tecnologias de menor custo, bem como onde haja alguma economia de escala.

As concessionárias da região Norte, que têm suas áreas de concessão recortadas pela imensa malha hidrográfica amazônica, propõem-se a atender primeiro às comunidades onde haja acesso por via terrestre, o que evita, a princípio, a implantação de uma dispendiosa logística fluvial para levar combustível e dar manutenção a essas comunidades (ANEEL, 2009). 


\subsection{ENERGIA SOLAR FOGOVOLGAICA}

O Sol é uma fonte abundante e renovável de energia. O total de energia vinda do Sol que incide sobre a superfície terrestre, em 24 horas, é superior à demanda energética mundial para um ano inteiro. A energia solar pode ser utilizada para, por exemplo, aquecer água ou ser convertida diretamente em eletricidade. Esta última aplicação está bastante difundida em vários países, como Alemanha, Espanha, Japão e Estados Unidos.

A conversão da energia solar diretamente em eletricidade ocorre devido ao chamado "efeito fotovoltaico" e é realizada pelos dispositivos fotovoltaicos (FV). Essa conversão ocorre de modo silencioso, sem emissão de gases, sendo desnecessária a assistência de operador para o sistema. É importante ressaltar que somente a componente luminosa da energia solar (fótons) é útil para a conversão fotovoltaica. A componente térmica da energia solar (radiação infravermelha) é utilizada em outros tipos de aplicações, tais como o aquecimento de água ou a geração de energia elétrica através de sistemas termo-solares com concentradores.

Em uma básica definição, sistema fotovoltaico é um conjunto integrado de módulos fotovoltaicos e outros componentes, projetado para converter a energia solar em eletricidade (MAYCOCK, 1981; TREBLE, 1991). O princípio físico de funcionamento dos módulos fotovoltaicos é denominado efeito fotovoltaico (foto= luz; volt= eletricidade), que é o fenômeno apresentado por determinados materiais que, expostos à luz, produzem eletricidade. Os módulos são compostos por células fotovoltaicas, e a conversão da radiação solar em energia elétrica é obtida utilizando-se material semicondutor como elemento transformador, conhecido como célula solar ou célula fotovoltaica. 


\section{Disponibilidade de irradiação solar no Brasil}

A irradiação solar é um dos principais dados necessários para o estudo de geração energética através de sistemas fotovoltaicos, tanto para seu dimensionamento, quanto para sua previsão de geração (CROS et al.;2004).

No Brasil, entre os esforços mais recentes e efetivos de avaliação da disponibilidade de irradiação solar, destaca-se o Atlas Brasileiro de Energia Solar, o qual foi desenvolvido dentro do escopo do projeto SWERA (Solar and Wind Energy Resource Assessment), financiado pelo Programa das Nações Unidas para o Meio Ambiente (PNUMA) e co-financiado pelo Fundo Global para o Meio Ambiente (GEF). O projeto SWERA tem como foco principal promover o levantamento de uma base de dados confiável e de alta qualidade visando auxiliar no planejamento e desenvolvimento de políticas públicas de incentivo a projetos nacionais de energia solar e eólica e atrair o capital de investimentos da iniciativa privada para a área de energias renováveis (PEREIRA et al.;2006).

A média anual do total diário de irradiação solar global horizontal incidente no território brasileiro mesmo com diferentes características climáticas, é possível observar que a média anual de irradiação global apresenta boa uniformidade. $O$ valor máximo, de $6,5 \mathrm{kWh} / \mathrm{m}^{2}$, ocorre no estado da Bahia, uma região de clima semiárido com baixa precipitação ao longo do ano e com a média de cobertura de nuvens mais baixa do país (INMET, 2009). 


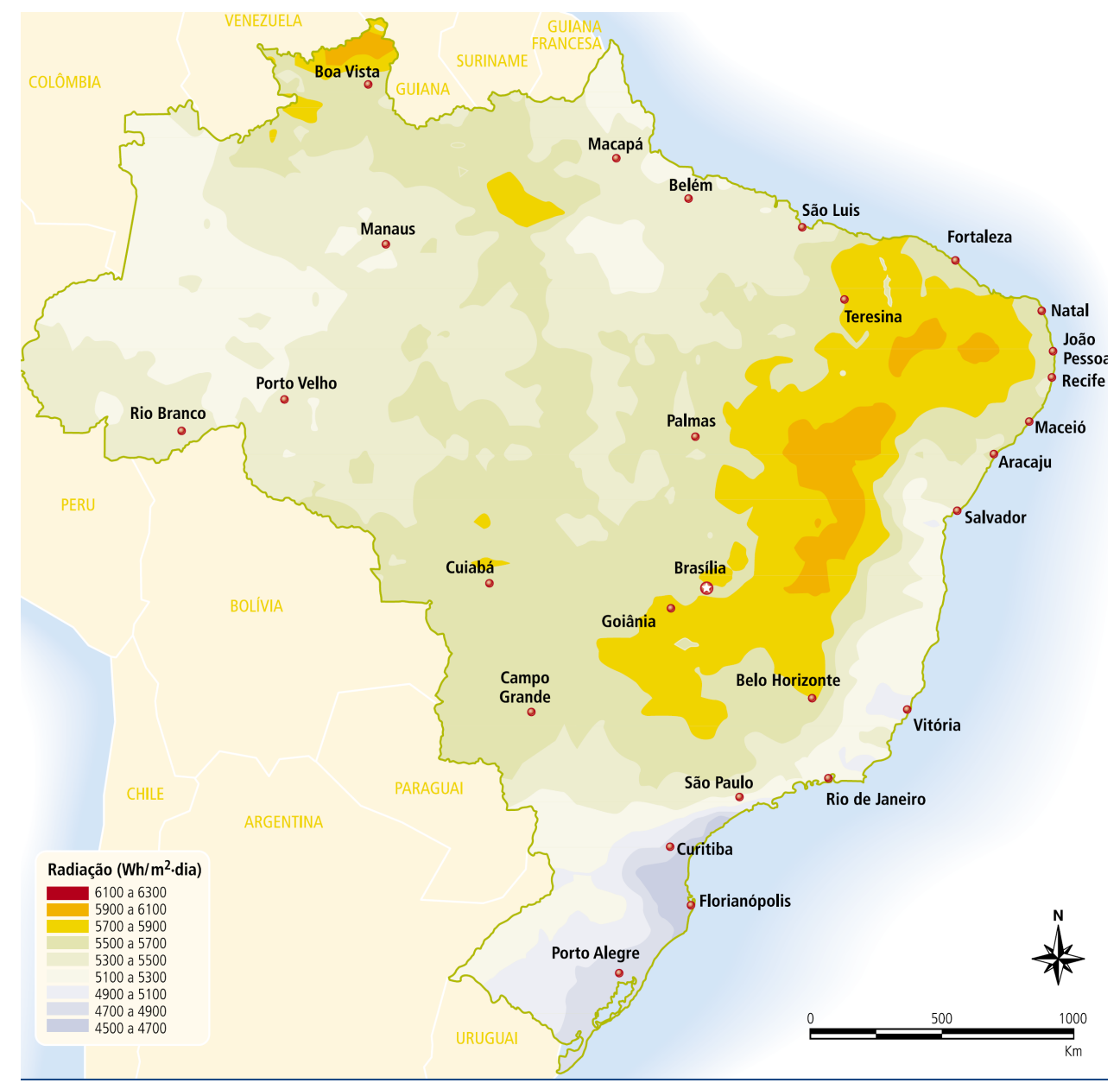

Figura 08: Atlas Brasileiro de Energia Solar demonstrando a média anual do total diário da irradiação solar.

Fonte: ANEEL, 2008.

Os maiores níveis de irradiação no plano inclinado ocorrem na faixa que vai do Nordeste ao Sudeste durante a Primavera e os menores valores em todas as regiões do Brasil ocorrem durante os meses de Inverno (PEREIRA et al.;2006). Os principais produtos consequentes do Projeto SWERA no Brasil, na área de energia solar, são mapas impressos e digitais de radiação solar de alta resolução; geração de séries temporais horárias; e construção de diferentes cenários de aproveitamento da energia solar desenvolvidos com o uso de ferramentas de um sistema de informações geográficas. 


\subsubsection{Células Solares Fotovoltaicas - Gecnologias}

O efeito fotovoltaico ocorre nas células solares fotovoltaicas, que são dispositivos construídos com materiais semicondutores. As células fotovoltaicas produzidas comercialmente, destinadas a aplicações terrestres, utilizam principalmente duas tecnologias: uma baseada no silício cristalino na forma de finas fatias de silício (Si), com espessura entre 0,18 e 0,25mm, e outra baseada em filmes finos, que consiste na deposição de películas de diferentes materiais sobre uma base ou substrato (RÜTHER, 2004).

A eficiência da conversão fotovoltaica é definida como a relação entre a potência elétrica de saída e a potência da radiação incidente, nas condições padrões de teste realizados em laboratório $\left(1000 \mathrm{~W} / \mathrm{m} 2,25^{\circ} \mathrm{C}\right)$. Ela pode ser influenciada tanto por fatores físicos (temperatura) como por fatores associados à tecnologia de fabricação das células (material), a qual tem sido melhorada constantemente (LASNIER e ANG, 1990).

A quantidade de energia elétrica fornecida por um painel fotovoltaico é tipicamente $80 \%$ daquela medida nas condições padrões de teste feitas em laboratório. Nas condições reais de utilização, os painéis estão geralmente cerca de $20^{\circ} \mathrm{C}$ mais quentes que a temperatura do ar, desse modo à eficiência de operação dos painéis chega a ser reduzida em $10 \%$ devido aos efeitos da temperatura. A diminuição de desempenho resulta da ligeira diferença de tensão entre os painéis, quando eles estão conectados para formar um arranjo fotovoltaico. Perdas ôhmicas nos condutores de conexão, sujeira e outros efeitos podem também contribuir para a redução do desempenho dos painéis. A natureza dessas perdas depende dos detalhes de projeto do sistema e localização da instalação (LASNIER e ANG, 1990). 


\section{Dódulo forovoltaico}

Um conjunto de células solares fotovoltaicas devidamente interligadas e acondicionadas forma o módulo fotovoltaico. A quantidade de células conectadas em série determina a tensão de operação do módulo e a quantidade de células conectadas em paralelo influencia na capacidade de corrente do módulo.

Os módulos fotovoltaicos são projetados e fabricados para: acomodar as células e as respectivas interligações elétricas, proporcionar suporte estrutural e proteção contra danos mecânicos e agentes ambientais externos, tais como sol, chuva, ventos e outros agentes climáticos, com expectativa de operar nessas condições por 30 anos ou mais (RÜTHER, 2004).

Quando um módulo é exposto à radiação solar apresenta em seus terminais uma tensão contínua. Os valores de tensão $(V)$, corrente $(A)$ e potência $(W)$ de um módulo são especificados pelo fabricante e são medidos sob determinadas condições, denominadas "condições-padrão de referência para ensaio" (ABNT, 2006).

Os módulos constituídos de células de silício cristalino são normalmente rígidos e os de filme fino podem ser construídos sobre vidro rígido, ou sobre substratos flexíveis, constituindo uma opção para instalação sobre superfícies curvas, como coberturas ou fachadas de edificações, além de serem relativamente mais leves.

As tecnologias de filmes finos são também bastante promissoras pelo fato de utilizarem pouca energia e pouca matéria prima na sua fabricação e por apresentarem grande potencial de redução de custos, se houver produção em grande escala. As células de filme fino de silício microcristalino são células híbridas, como as desenvolvidas as desenvolvida pela SANYO e pela SONTOR, compostas por uma fina fatia de silício monocristalino entre duas películas de silício amorfo (SANYO, 2008; SONTOR, 2008). A tecnologia do silício cristalino (m-Si e p-Si) representa cerca de $80 \%$ da produção mundial de módulos e os $20 \%$ restantes estão divididos pelos diferentes tipos de filmes finos. 
Os módulos de primeira geração utilizam como base o silício cristalino, sendo esta a maior barreira para a difusão desta tecnologia. Isto porque o custo final é bastante elevado, visto que $40 \%$ do custo são provenientes da fatia de silício utilizada na fabricação da célula (GREEN, 2004). A principal vantagem desta tecnologia é a alta eficiência alcançada, cerca de 10 a $16 \%$, em média. Dentro da tecnologia fotovoltaica de primeira geração encontra-se uma, introduzida mais recentemente no mercado, conhecida como tecnologia HIT (heterojunction with intrinsic thinlayer). Os módulos desta tecnologia são compostos por duas camadas de silício amorfo e uma camada central de silício monocristalino e possuem eficiência ainda mais elevada, em torno de $17 \%$. Outra aposta dentre os módulos de primeira geração, são os módulos de silício com backcontact, os quais atingem eficiências de até 19\%. Já nos módulos da segunda geração, apenas uma fina camada do material fotovoltaico é depositada sobre um substrato. Isto significa uma redução de até 100 vezes de material ativo. Além disso, a unidade comercial deixa de ser uma célula e passa a ser um módulo, unidade cerca de 100 vezes maior (GREEN, 2004). Como a camada do material semicondutor é muito fina, da ordem de $1 \mu \mathrm{m}$, praticamente todos os semicondutores não parecem caros em relação à quantidade empregada e, dentre eles, tem se destacado o silício. Sendo o silício barato o suficiente para ser usado em fatias, em filmes finos sua aplicação torna-se ainda mais vantajosa.

Recentemente, uma nova tecnologia de célula fotovoltaica, a terceira geração, tem chamado a atenção de pesquisadores. Trata-se de uma célula composta por dióxido de Titâneo nanocristalino combinado com um corante orgânico, inicialmente desenvolvido na Suíça por Michael Graetzel. São as células solares sensibilizadas por corante (CSSC). A principal característica é seu baixo custo além da facilidade de fabricação, podendo, inclusive, ser desenvolvida em laboratórios escolares (GREEN, 2004). A eficiência obtida nesses experimentos é baixa, mas, às vezes, o custo é tão importante quanto a eficiência (AGNALDO et al., 2006). Em grande escala, isto pode significar uma grande economia quando comparada às células de filmes finos. A eficiência de cada tecnologia depende do elemento utilizado. Desta forma, pode-se escolher, entre as opções existentes, qual delas atende melhor aos objetivos de 
cada projeto. Por exemplo, se a intenção é utilizar uma pequena área com o intuito de gerar o máximo de energia, deve-se optar pela tecnologia mais eficiente. Já se o limitante não é a área, mas sim custo, pode-se optar por uma tecnologia menos eficiente, que ocupará uma maior área, porém com custos mais atraentes.

A maioria das células solares fotovoltaicas é feita de silício e, de acordo com os especialistas, levará no mínimo, mais de uma década até que outra tecnologia venha a dominar o mercado (BRAGA et al., 2008; MURRAY et al., 2006). Cerca de 95\% de todas as células solares do mundo são de silício, sendo o segundo elemento químico mais utilizado na Terra (DGS, 2008). O uso predominante desse material para a fabricação de módulos comerciais se deve ao bom domínio de sua tecnologia, ao seu alto rendimento relativo e à sua confiabilidade demonstrada durante várias décadas (CHIVELET, 2010). Dentre as opções existentes atualmente, pode-se citar as células de Silício cristalino (c-Si), as de Silício amorfo hidrogenado (a-Si), as HIT, baseadas em Silício cristalino com uma camada de silício amorfo, as células de Telureto de Cádmio (CdTe) e outros compostos relacionados ao Cobre e ao Índio (CIS). Estes últimos elementos são altamente tóxicos e raros. Desta forma, a tecnologia CIS encontra uma forte barreira para sua utilização, sendo as células baseadas em Silício cristalino (mono ou poli) e Silício amorfo, as mais largamente utilizadas. Em 2007, as tecnologias de silício policristalino e silício monocristalino foram as mais empregadas, com um total de $87,4 \%$ de participação no ano. As células de silício policristalino atingiram 45,2\% de participação, conforme o gráfico 07 .

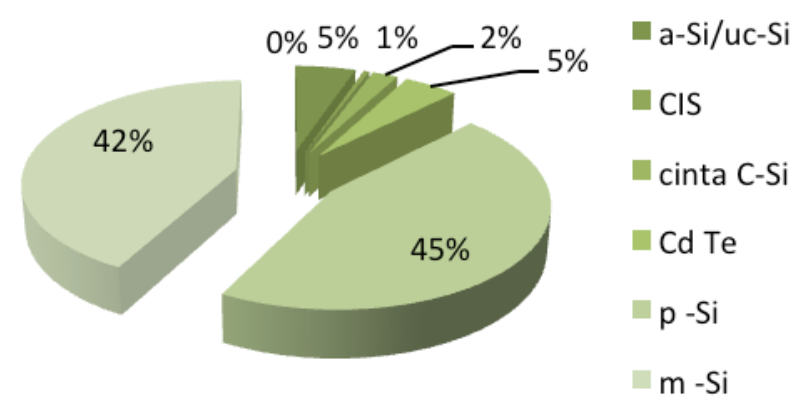

Gráfico 07: Participação por tecnologia fotovoltaica em 2007 (adaptado).

Fonte: EPIA e GREENPEACE, 2008. 
O material utilizado nas células solares deve ser da maior pureza possível, o que pode ser obtido através de sucessivas etapas na produção química (DGS, 2008). Além do elemento utilizado na célula fotovoltaica, outro fator que determina a eficiência do módulo é a sua relação de potência nominal $x$ área. Quando se tem dois módulos de mesma potência, será mais eficiente aquele de menor área. O quadro 07 apresenta uma série de fabricantes de módulos, a maioria baseados em Silício, tanto amorfo, quanto cristalino e suas respectivas eficiências.

\begin{tabular}{|c|c|c|c|c|c|}
\hline Tecnologia & Fabricante & Modelo & Potência (W) & Área $\left(\mathrm{m}^{2}\right)$ & EFF STC (\%) \\
\hline cssc & Konarka & KT3000 & 26 & 1,55 & 1,70 \\
\hline \multirow[t]{4}{*}{$A-S I$} & \multirow[t]{2}{*}{ Schott Solar } & Schot & \multirow[t]{2}{*}{100} & \multirow[t]{2}{*}{1,45} & \multirow[t]{2}{*}{7,00} \\
\hline & & ASI100 & & & \\
\hline & Uni Solar & PVL-136 & 136 & 2,16 & 6,30 \\
\hline & Sonsor & SN2-145 & 145 & 1,78 & 8,15 \\
\hline HIT & Sanyo & HIP- 205BA3 & 205 & 1,18 & 17,40 \\
\hline \multirow[t]{3}{*}{$\mathrm{m}-\mathrm{Si}$} & Shell Solar & Ultra $175-\mathrm{PC}$ & 175 & 1,32 & 13,30 \\
\hline & Suntech & PLUTO 200-ADA & 200 & 1,28 & 17,00 \\
\hline & Sunpower & 315solarpanel & 315 & 1,63 & 19,30 \\
\hline \multirow[t]{4}{*}{$\mathbf{p}-\mathbf{S i}$} & BPsolar & SX 3200B & 200 & 1,41 & 13,50 \\
\hline & Solon & Blue 220/07 & 220 & 1,61 & 13,41 \\
\hline & Sharp & ND - $220 U 2$ & 220 & 1,63 & 13,50 \\
\hline & Kyocera & KD210GX-LP & 210 & 1,49 & 14,00 \\
\hline
\end{tabular}

Quadro 07: Características de módulos fotovoltaicos de diferentes tecnologias e dimensões.

Fonte: RUTHER, 2004.

Pelo quadro, pode-se perceber que a tecnologia mais eficiente é a de silício monocristalino, com eficiência de conversão de até 19,3\%. Em seguida, aparece a tecnologia HIT, com 17,40\%. A tecnologia com menor eficiência é a de CSSC, com apenas 1,7\% de eficiência, seguida pela de silício amorfo, com praticamente a metade da eficiência das demais tecnologias.

As células fotovoltaicas possuem dois terminais que apresentam tensão elétrica em torno de $0,6 \mathrm{~V}$, quando as mesmas são expostas à luz solar. Salvo poucas aplicações não é comum 
utilizar-se uma única célula para fornecer energia elétrica, sendo mais usual a utilização de conjuntos de células para alimentar determinado consumidor (LABEEE, 2010).

\subsubsection{Sistemas Fotovoltaicos}

Sistema fotovoltaico (SFV) é a denominação que recebe o conjunto de elementos necessários para realizar a conversão direta da energia solar em energia elétrica, com características adequadas para alimentar aparelhos elétricos e eletrônicos, tais como lâmpadas, televisores, geladeiras e outros. O SFV tem o painel fotovoltaico como principal componente e pode incluir, dependendo da aplicação, dispositivos para controle, supervisão, armazenamento e condicionamento de energia elétrica. Fazem parte também de um SFV a fiação, a estrutura de suporte e a fundação, quando necessária.

Os sistemas fotovoltaicos são classificados em: sistemas isolados e sistemas conectados à rede $(A B N T, 2008)$.

a) Sistemas isolados: são aqueles que não possuem conexão com a rede elétrica pública de fornecimento de energia. Os sistemas isolados normalmente necessitam de um banco de baterias para armazenar a energia gerada e fornecê-la nos períodos nos quais não há radiação solar. Os sistemas fotovoltaicos que se enquadram neste caso usualmente têm os seguintes componentes principais: painel fotovoltaico, controlador de carga, banco de baterias e inversor, como mostrado na Figura 09. O controlador de carga é um aparelho eletrônico destinado a controlar e monitorar a carga e/ou a descarga do banco de baterias e o inversor é o aparelho que converte a tensão contínua, proveniente do painel fotovoltaico ou do banco de baterias, em tensão alternada, com características adequadas para alimentação de aparelhos elétricos e eletrodomésticos comuns. 


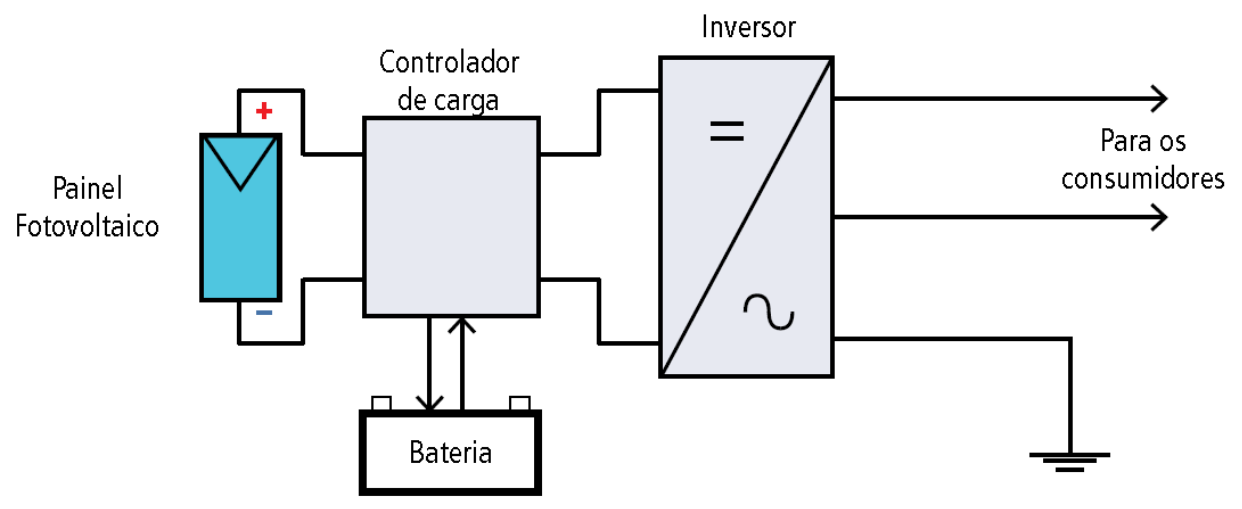

Figura 9: Constituição básica do sistema fotovoltaico isolado.

Fonte: LABEEE, 2010.

b) Sistemas conectados à rede: são aqueles efetivamente conectados à rede elétrica pública. Neste caso, a energia gerada é injetada diretamente na rede e não há necessidade de banco de baterias. Os sistemas conectados são constituídos basicamente de painel fotovoltaico e inversor, aos quais se somam os componentes de comando e proteção (chaves, fusíveis, disjuntores, etc.). A Figura 10 ilustra a constituição básica deste tipo de sistema no qual o inversor, ao detectar a presença da rede, converte a tensão contínua vinda do painel fotovoltaico em tensão alternada, com o mesmo padrão de tensão, frequência e fase da rede elétrica à qual está conectado. A energia é injetada diretamente na rede elétrica e o inversor se desliga automaticamente, cessando o fornecimento, caso seja desconectado da rede ou a rede seja desenergizada.

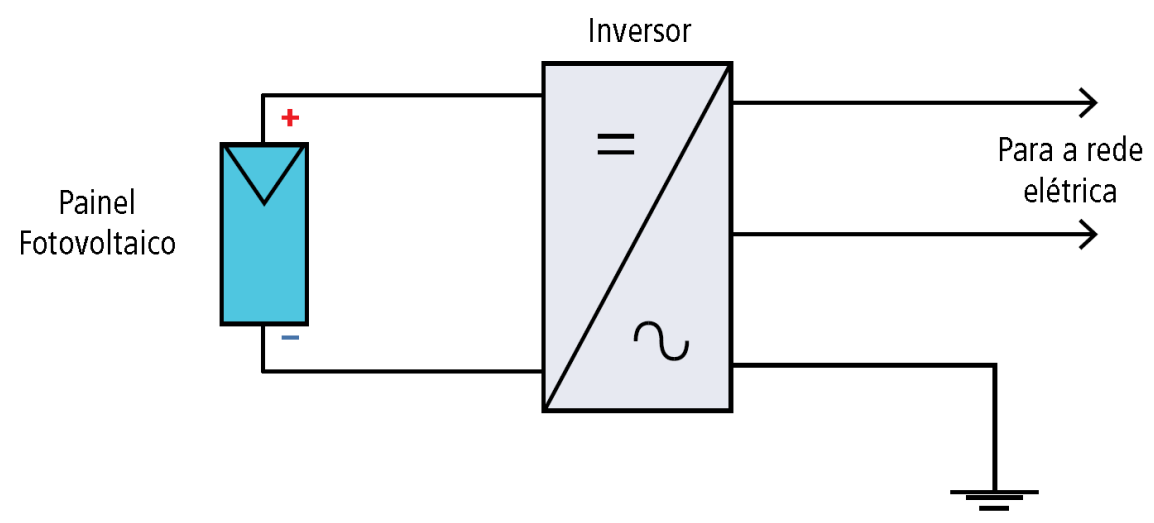

Figura 10: Constituição básica do sistema fotovoltaico conectado a rede.

Fonte: LABEEE, 2010. 
Os sistemas fotovoltaicos conectados à rede podem ser instalados como uma planta fotovoltaica, gerando energia de forma centralizada, semelhante a uma usina geradora convencional. A planta normalmente é situada distante do ponto de consumo e necessita de linhas de transmissão para levar a energia gerada à rede elétrica dos consumidores.

Outro modo de instalar os sistemas fotovoltaicos conectados à rede é integrá-los às edificações urbanas, como casas e edifícios, na cobertura ou na fachada. Neste caso, a geração é descentralizada e ocorre junto ao ponto de consumo, pois a energia gerada pode ser utilizada pela própria edificação. Caso haja geração que exceda o consumo, o excedente é enviado para a rede pública, sendo utilizado por outros consumidores. Quando a geração for insuficiente para atender ao consumo da edificação, a energia virá da rede elétrica pública. Esse tipo de sistema integrado a edificações, pelo fato de não necessitar de linhas de transmissão, tem a vantagem de evitar as perdas de energia que ocorrem nessas linhas, como acontece no caso das plantas centralizadas, cuja energia gerada deve ser levada até aos consumidores pelas linhas de transmissão.

Do ponto de vista de instalações elétricas e da construção civil as tecnologias necessárias à integração de sistemas fotovoltaicos às edificações já estão bem estabelecidas. Os componentes para os sistemas são comercialmente disponíveis e a conexão à rede pode ser executada sem qualquer problema de ordem elétrica (LABEEE, 2011). No Brasil um dos exemplos de aplicação deste conceito encontra-se na Casa Eficiente, do LABEEE, onde está instalado um sistema solar fotovoltaico conectado à rede com o painel integrado à cobertura. Outros sistemas deste tipo têm sido instalados e avaliados durante vários anos sob diversos aspectos (arquitetônico, energético, econômico, de eficiência e confiabilidade), com resultados apresentados em artigos nacionais e internacionais (RÜTHER, 1998; VIANA et al., 2007; RÜTHER et al., 2008).

A Alemanha, um dos principais mercados da tecnologia fotovoltaica, instituiu tarifas diferenciadas para a energia gerada pelos sistemas fotovoltaicos integrados às edificações. As concessionárias de energia alemãs são obrigadas a comprar toda a energia gerada pelos SFVs 
a uma tarifa quase 3 vezes maior do que a tarifa convencional, com tarifa diferenciada garantida por 20 anos (ALEMANHA, 2004). Este programa tornou atrativo o investimento em SFVs conectados à rede e propiciou o desenvolvimento da tecnologia. O custo desse programa de incentivo é diluído na tarifa de energia de todos os consumidores, proporcionando um impacto desprezível (menor do que 1\%) na conta mensal de cada consumidor.

O Brasil é um país rico em fontes renováveis de energia e reúne condições necessárias e suficientes para estabelecer uma lei de incentivo à geração distribuída, em particular à geração de energia solar FV conectada à rede, a exemplo da que foi estabelecida na Alemanha, Espanha e vários outros países. Diversas iniciativas estão em andamento no sentido de legislar e regulamentar o assunto, sendo a mais recente a Portaria N 36 de 26/11/2008 da Secretaria de Planejamento e Desenvolvimento Energético, do Ministério de Minas e Energia, que cria o GTGDSF, Grupo de Trabalho de Geração Distribuída com Sistemas Fotovoltaicos. A finalidade do GT-GDSF é elaborar estudos, propor condições e sugerir critérios destinados a subsidiar uma proposta de política de utilização de geração fotovoltaica conectada à rede, em particular integrada em edificações urbanas, como um fator de otimização da gestão da demanda de energia e de promoção ambiental do País, em curto, médio e longo prazo (BRASIL, 2008).

No âmbito das normas técnicas relativas à energia solar fotovoltaica, a Comissão de Estudos de Sistemas de Conversão Fotovoltaica de Energia Solar, da ABNT (Associação Brasileira de Normas Técnicas), trabalha na revisão e atualização de normas, já tendo como resultados a publicação da NBR 10899:2006 - Energia solar fotovoltaica - Terminologia e da NBR 11704:2008 - Sistemas fotovoltaicos - Classificação. A NBR 11876 - Módulos fotovoltaicos - Especificação, já revisada, encontra-se em fase de consulta nacional, devendo ser publicada brevemente e a NBR 11877 - Sistemas fotovoltaicos - Especificação encontra-se em processo de revisão. 


\subsubsection{Sistemas Fotovoltaicos Conectados á Rede no Brasil}

No Brasil, os sistemas fotovoltaicos conectados à rede são poucos e de caráter experimental. De acordo com Fraidenraich (2002), Winrock International - Brazil (2002) e Zilles (2004), as principais aplicações da tecnologia solar fotovoltaica no país são relativas à telecomunicação, à eletrificação rural, aos serviços públicos e ao bombeamento de água. Estima-se uma potência total instalada de sistemas fotovoltaicos autônomos de cerca de 20 MW, dos quais $70 \%$ estão localizados nas Regiões Norte, Nordeste e Centro-Oeste (Zilles, 2008a), e de sistemas conectados à rede de 0,153 MWp (Varella, 2009). No entanto, o Brasil possui um grande potencial de irradiação solar, maior do que duas vezes o potencial da Alemanha, país líder de sistemas fotovoltaicos em capacidade instalada conforme quadro 08 .

\begin{tabular}{|l|l|l|l|}
\hline & Alemanha & Espanha & Brasil \\
\hline Capacidade instalada (MW) & 3.800 & 451 & $0,152^{*}$ \\
\hline Potencial (kWh/m².ano) & 900 & 1.800 & 1.950 \\
\hline
\end{tabular}

Quadro 08: Capacidade instalada de sistema fotovoltaico e potencial solar na Alemanha, Espanha e Brasil (*sistemas conectados à rede).

Fonte: Zilles, 2008 e Varella, 2009.

Os sistemas fotovoltaicos para eletrificação rural e bombeamento de água que têm sido tradicionalmente utilizados no Brasil atende cargas elétricas distantes da rede elétrica convencional, normalmente em zonas rurais.

Dependendo do local a ser atendido, tais sistemas representam soluções adequadas e podem ser economicamente viáveis em função dos elevados custos de expansão da rede elétrica (MARKVART, 2000; WINROCK INTERNATIONAL - BRAZIL, 2002). Este é o caso de pequenos sistemas fotovoltaicos autônomos de geração de energia elétrica com potência variando de $100 \mathrm{Wp}$ a $150 \mathrm{Wp}$, que são implantados para atender residências rurais com iluminação básica e alguns periféricos (CRESESB, 2005). 
De acordo com o relatório desenvolvido por Winrock International - Brazil (2002), mais de 40 mil sistemas fotovoltaicos autônomos foram instalados com o intuito de amenizar o problema da falta de acesso à energia elétrica em várias regiões do país. Algumas iniciativas envolvendo esses sistemas foram viabilizadas através de concessionárias de energia, instituições de ensino, centros de pesquisa, governos estaduais e municipais. Dentre elas pode-se citar o Programa Luz Solar, desenvolvido em Minas Gerais; o Programa Luz do Sol, na Região Nordeste; e o Programa Luz no Campo, de dimensão nacional. Além dos sistemas mencionados, outros inúmeros sistemas fotovoltaicos autônomos continuam sendo instalados em todo o território nacional através do apoio de Organizações Não Governamentais Internacionais, viabilizados pela cooperação internacional via entidades locais, particularmente pela Agência Alemã de Cooperação Técnica (GTZ) e pelo Laboratório de Energia Renovável dos Estados Unidos (NREL/DOE) (ANEEL, 2002).

De acordo com Zilles (2005) e Zilles (2008), de 2002 a 2008 foram instalados no país 120,4 kWp em sistemas fotovoltaicos conectados à rede elétrica, Todos os sistemas fotovoltaicos conectados à rede de 1995 até 2008 , totalizam $152,511 \mathrm{kWp}$. 


\section{5. ЋIDROGÊnIO COMO COMBUSGÍVEL}

Há séculos o homem descobriu no hidrogênio uma fonte ideal de energia. Sabe-se que mais de $90 \%$ de toda a matéria existente no universo é composta por este elemento, sendo, deste modo, considerada fonte fundamental para a vida, compondo a água e a quase totalidade de matéria orgânica, além de constituir-se como fonte de energia do Sol.

Porém, apesar da enorme quantidade e presença, seu emprego como combustível não é tarefa simples. Em contraposição ao petróleo, o hidrogênio não é fonte primária de energia, somente sendo encontrado na Terra em moléculas como a água ou em diversos tipos de matéria orgânica, e a partir dos quais deve ser extraído.

Atualmente já existe o termo "economia do hidrogênio" que está associado à estruturação necessária à produção, armazenamento, transporte e utilização do hidrogênio como uma alternativa substitutiva aos combustíveis fósseis. Mudanças extremas serão esperadas, visto que a matriz energética mundial é fortemente influenciada pelo petróleo.

Uma das principais razões dos países envolvidos na implantação da economia do hidrogênio (IPHE, etc) é o fato do hidrogênio ser um vetor energético limpo e que pode ser obtido de uma infinidade de fontes diferentes, fósseis ou renováveis.

\footnotetext{
"Desta forma, fica evidente que os principais países que demonstram interesse na implantação dessa nova economia são aqueles que apresentam uma maior demanda energética, e por conseqüência, os maiores níveis de emissões de gases de efeito estufa. A economia do hidrogênio também é uma solução para a questão de segurança energética causada pela grande dependência energética desses países por combustíveis fósseis importados, além de ser uma alternativa estratégica em países que possuem outras fontes de energia" (CGEE, 2010).
}

O hidrogênio, elemento simples e abundante, de baixíssimo impacto ambiental, torna-se cada vez mais uma alternativa energética atraente. A inserção deste insumo na estrutura energética mundial proporcionará um prolongamento da utilização das reservas fósseis, mitigação da poluição, maiores potencialidades para devido aproveitamento energético, 
segurança no fornecimento energético, inclusão energética em comunidades de difíceis acessos à rede elétrica convencional, redução da dependência energética em regiões importadoras de energia e retornos econômicos bastante favoráveis, pois novos produtos gerados, como o próprio hidrogênio e oxigênio, este último para o caso da ocorrência da eletrólise da água, teriam poder de troca.

Uma busca por novas fontes geradoras de energia faz-se necessária, pois com a crescente população mundial e a busca incessante pelo crescimento econômico por parte de países em desenvolvimento resulta em céleres incrementos na demanda energética mundial. Uma alternativa para devido abastecimento de energia seria uma intensificação do aproveitamento dos recursos renováveis, como as energias eólica e solar. Estas são fontes intermitentes, pois há variações sazonais nas saídas de potências de seus sistemas.

Pode-se obter o hidrogênio através da eletrólise que é um processo existente há muitos anos e considerado bastante eficiente para que se realize a extração do hidrogênio de forma a não poluir. Em tal procedimento, basta submeter-se água à corrente elétrica - empregando energia proveniente de fontes renováveis, como eólica e solar - para que ela se dissocie em hidrogênio e oxigênio (seus elementos básicos).

Segundo Silva, E. P. (1991), o processo consiste em passar uma corrente elétrica na água na presença de eletrodos inertes em meio condutor básico ou ácido. As reações produzidas têm como resultado a decomposição da água. Os elementos resultantes desse processo sempre será o hidrogênio e o oxigênio, seja qual for o sistema como pode ser verificado na equação abaixo:

Reação: $\mathrm{H}_{2} \mathrm{O} \rightarrow 2 \mathrm{H}^{-}+\mathrm{O}^{2}-$ 
A figura 11 mostra o processo de eletrólise da água, o primeiro vidro corresponde ao oxigênio e ao ânodo, o segundo vidro ao hidrogênio e ao catodo e no meio há uma placa de platina:

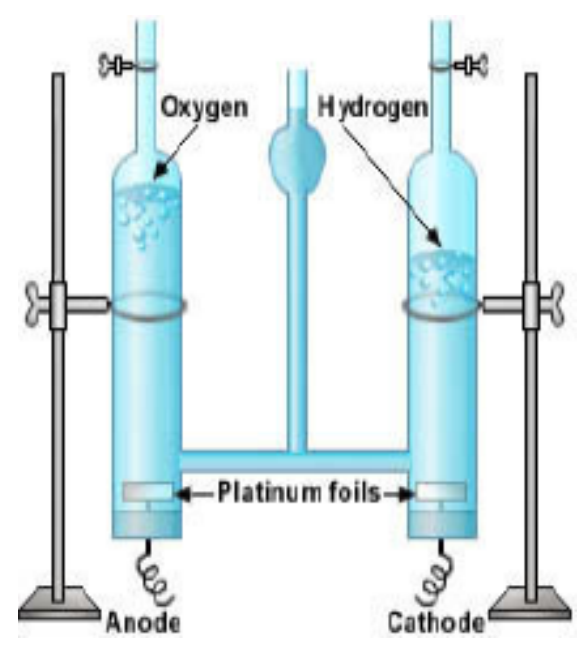

Figura 11. Eletrólise da água.

Fonte: SILVA, WICAC 2006.

\subsubsection{Eletrolisador}

Os eletrolisadores são conhecidos a mais de 50 anos, mas foi a partir da década de 60 , com o desenvolvimento da indústria aeroespacial pesquisas avançadas em torno da eletrolise da água para obtenção do hidrogênio começaram a surgir com mais vigor.

Para que o processo aconteça necessita-se de um equipamento chamado eletrolisador, que pode ser classificado em duas categorias, os convencionais, desenvolvidos durante a primeira metade do século $X X$, e avançados os quais se encontram em desenvolvimento tecnológico (SILVA, E. P., 1991). A figura 12 mostra um eletrolisador. 


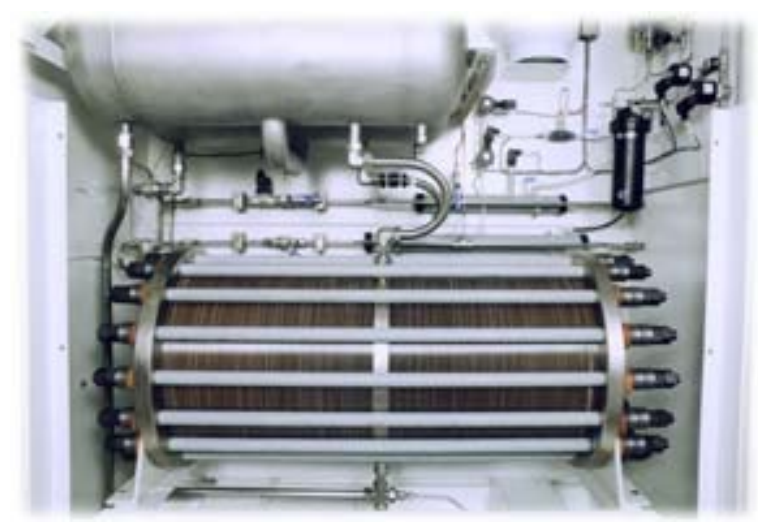

Figura 12: Eletrolisador do tipo filtro prensa modelo $H 2$ IGEN®

Fonte: Stuart Energy Systems, 2008.

Disponivel em http://www.stuartenergy.com/.

Os maiores fabricantes mundiais de eletrolisadores atualmente são as empresas: Norsk Hydro, Teledyne Energy Systems, Próton Energy Systems e Stuart Energy Systems.

Os principais componentes do processo de eletrolise são o eletrolisador, a unidade de potência, o separador de gases, a unidade de purificação e as unidades de armazenamento (SILVA, E. P., 1991). Os componentes são ilustrados na figura 13 seguinte:

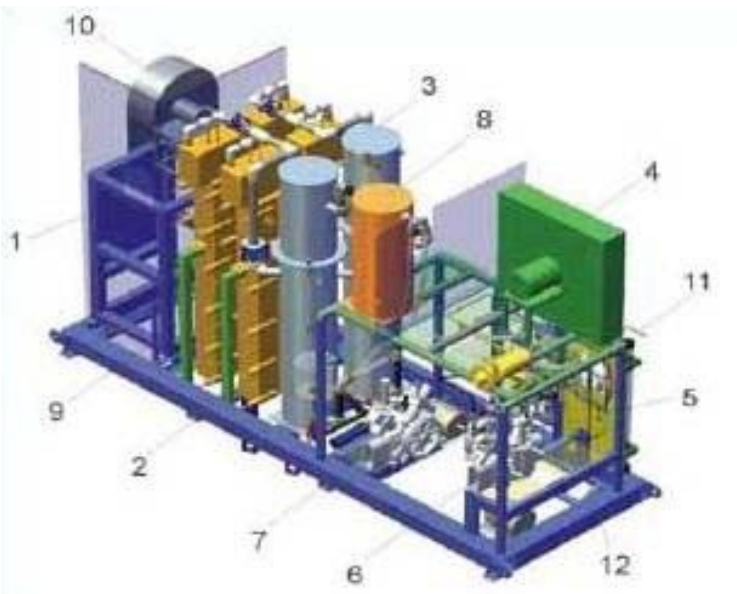

1. Retificador e Painel de Controle

2. Eletrolisador

3. Separador de gases

4. Sistema de Refrigeração

5. Desumidificador e Purificador

6. Compressor de serviço

7. Compressor reserva

8. Vaso de Pressão

9. Deionizador

10. Sistema de Ventilação

11. Ponto de entrega do Hidrogênio

12. Detector de Vazamento de Hidrogênio.

Figura 13: Principais componentes de um Eletrolisador.

Fonte: Stuart Energy, 2008.

Disponível em http://www.stuartenergy.com/. 
O processo de eletrólise da água para a produção de hidrogênio é conhecido e utilizado por várias indústrias no Brasil, quais sejam: empresas que demandam hidrogênio como insumo químico, alimentícias e petroquímicas, ou empresas que utilizam processos eletrolíticos para a obtenção de outros produtos, tais como a produção de cloro e soda cáustica, gerando hidrogênio como subproduto. Apesar da disponibilidade energética, a eletrólise da água tem uso limitado no Brasil devido ao alto custo de produção do hidrogênio quando comparado ao processo de reforma de gás natural (MME, 2005).

No momento existem projetos de demonstração sendo desenvolvidos por universidades e empresas de energia para a geração de hidrogênio eletrolítico para aplicações energéticas. O país conta também com plantas eletrolíticas importadas, que produzem hidrogênio com diversos fins industriais. Alguns laboratórios brasileiros têm mais de 20 anos de experiência nas áreas de geração, purificação e compressão de hidrogênio eletrolítico.

Em relação à geração hidráulica, o armazenamento de hidrogênio traz outras vantagens, uma alternativa bastante interessante aqui no Brasil para realizar a eletrólise da água é quando a energia que chega às barragens é superior à energia gerada, elas são obrigadas a verter o excesso de água. Por outro lado, a água que seria vertida poderia ser usada em eletrolisadores, levando ao aproveitamento pleno da capacidade de novas usinas. Nos momentos de alta demanda energética (nos horários de picos) a energia estocada na forma de hidrogênio poderia ser utilizada (MME, 2005).

Quanto aos eletrolisadores ainda são classificados como convencionais e avançados (SOUZA, 1998). Os eletrolisadores convencionais possuem como meio condutor iônico o hidróxido de potássio $(\mathrm{KOH})$, que, entre os meios básicos economicamente interessantes, oferece a menor resistência iônica, sendo, por isso, o mais utilizado. Esses eletrolisadores, quando comparados aos avançados, são de dimensões maiores e baixas correntes por unidade de área dos eletrodos, são feitos à base de materiais convencionais, e tem eficiências menores (SOUZA, 1998). 
Os eletrolisadores convencionais são classificados em unipolares ou bipolares. Os eletrolisadores unipolares, também chamados eletrolisadores tipo tanque, possuem os eletrodos com uma única polaridade (positiva ou negativa), de forma que em cada um deles se processa apenas uma reação produzindo somente um gás (H2 ou $\mathrm{O} 2$ em ambos os lados do eletrodo). Nos eletrolisadores unipolares há elevadas correntes e baixas tensões (SOUZA, 1998). Nos eletrolisadores bipolares, também conhecidos como eletrolisadores tipo filtro-prensa, todos os eletrodos, exceto os que se localizam nas extremidades, têm duas polaridades, funcionando como anodos (produção de O2) em uma das faces e como catodos (produção de H2) na outra face. Nos eletrolisadores bipolares há menores correntes e mais altas tensões (SOUZA, 1998). Os eletrolisadores avançados se originaram dos programas espaciais norte-americanos. 0 objetivo desta tecnologia é a obtenção de estruturas compactas, aumento da eficiência e diminuição dos custos. Entre as principais tecnologias destacam-se os eletrolisadores avançados do tipo PEM (Proton Exchange Membrane) (BARBIER, 2005). A principal característica do eletrolisador PEM é ter um eletrólito sólido. O eletrólito é uma fina membrana polimérica chamada comercialmente de Nafion. Este eletrólito também serve como uma membrana separadora, permitindo maior proximidade dos eletrodos (BARBIER, 2005). O quadro 09 mostra os eletrolisadores disponíveis no mercado. 


\begin{tabular}{|c|c|c|c|c|c|c|c|}
\hline Marca & Modelo & Tipo & $\begin{array}{c}\text { Taxa de } \\
\text { produção de } \\
\text { H2 (Kg/dia) }\end{array}$ & $\begin{array}{c}\text { Consumo de } \\
\text { energia } \\
(\mathrm{kWh} / \mathrm{Kg})\end{array}$ & $\begin{array}{l}\text { Fluxo } \\
\text { de } \\
\text { água }\end{array}$ & Eficiência & $\begin{array}{c}\text { Pureza } \\
\text { do H2 }\end{array}$ \\
\hline Avalence & $\begin{array}{c}\text { Hydrofiller } \\
175\end{array}$ & Bipolar & 10 & 60,5 & 4,5 & $89 \%$ & $99,7 \%$ \\
\hline Próton & Hogen380 & PEM & 22 & 70,1 & 8,4 & $95 \%$ & $99,99 \%$ \\
\hline Teledyne & EC 750 & Bipolar & 91 & 62,3 & 42 & $80 \%$ & $99,99 \%$ \\
\hline \multirow[t]{4}{*}{ Stuart } & $\begin{array}{c}1000 \\
\text { (1pilha) }\end{array}$ & \multirow[t]{4}{*}{ Bipolar } & 11 & \multirow[t]{4}{*}{53,4} & \multirow[t]{4}{*}{60} & \multirow[t]{4}{*}{$80 \%$} & \multirow[t]{4}{*}{$99,99 \%$} \\
\hline & $\begin{array}{c}1000 \\
\text { (2pilhas) }\end{array}$ & & 65 & & & & \\
\hline & $\begin{array}{c}1000 \\
\text { (3pilhas) }\end{array}$ & & 97 & & & & \\
\hline & $\begin{array}{c}1000 \\
\text { (4pilhas) }\end{array}$ & & 129 & & & & \\
\hline \multirow[t]{2}{*}{ Nork } & $\begin{array}{c}5040 \\
(400 A)\end{array}$ & \multirow[t]{2}{*}{ Bipolar } & \multirow[t]{2}{*}{$\begin{array}{c}813 \\
1046\end{array}$} & \multirow[t]{2}{*}{53,5} & \multirow[t]{2}{*}{485} & \multirow[t]{2}{*}{$73 \%$} & \multirow[t]{2}{*}{$99,9 \%$} \\
\hline & $\begin{array}{c}5040 \\
(5150 A)\end{array}$ & & & & & & \\
\hline
\end{tabular}

Quadro 09: Características dos eletrolisadores disponíveis no mercado (NREL, 2008).

Fonte: WICAC, 2010.

\subsubsection{Détodos de Armazenamento do நidrogênio}

Atualmente uma das principais causas que dificultam a utilização do hidrogênio como matriz energética é o seu armazenamento. Por se tratar de um gás de baixa densidade, 0 hidrogênio possui alta densidade energética por unidade de massa $\left(141,9 \mathrm{MJ} . \mathrm{kg}^{-1}\right)$, mas baixa densidade energética por unidade de volume (12,75 MJ.m ${ }^{-3}$. Desta forma, para a armazenagem de grandes quantidades de energia é necessário que o gás seja comprimido de alguma forma.

A armazenagem do hidrogênio é, sem dúvida, uma das grandes barreiras a serem vencidas antes que este se torne um vetor energético viável. Deve-se perceber a importância deste problema para o tema aqui abordado, quando o hidrogênio deverá ser armazenado para posterior reconversão em energia elétrica. Muitas pesquisas nessas áreas vêm sendo realizadas e alternativas diversas são regularmente propostas, sendo que três tecnologias podem, atualmente, ser empregadas em escala industrial. São elas: 
O hidrogênio, após ser produzido, pode ser diretamente armazenado em gasômetros a uma pressão um pouco superior à atmosférica; esta tecnologia já é bem dominada pelas empresas produtoras de gases industriais, gás natural, gás de cidade, etc. Os gasômetros são tanques cilíndricos que se caracterizam por apresentar um volume variável, ou seja, aumenta com a entrada de gás e diminui com a saída do mesmo (SILVA, 1991).

O hidrogênio, após ser armazenado nos gasômetros, pode ser pressurizado em cilindros, os quais permitem o armazenamento de uma quantidade maior de massa por volume armazenado. Estes cilindros podem ter uma pressão de trabalho de 50 a 200 bar (5.106 a 2.107 $\mathrm{Pa}$ ), sendo os de menor volume para o transporte a granel em carretas e os de maior volume para o armazenamento no local. Empresas do ramo de gases industriais tem uma grande experiência acumulada neste tipo de armazenamento (ZWANZIGUER, 1980; SILVA, 1991). Um reservatório cilíndrico de 50 litros $(0,05 \mathrm{~m} 3)$ à uma pressão de 200 bar contém cerca de $0,9 \mathrm{~kg}$ de hidrogênio e tem uma densidade energética de 0,6 MWh.m-3 (2,16.106 J)(FRIBERG, 1993). A figura 14 mostra um armazenamento de hidrogênio feito para uma residência em Nova Jersey, EUA com autonomia para dias nublados de 6 meses.

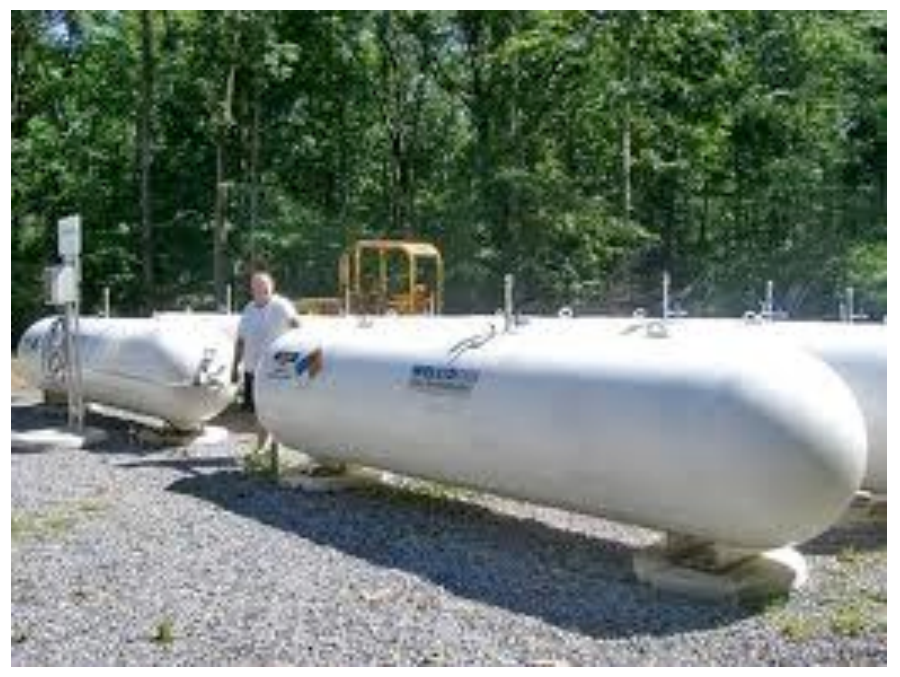

Figura 14: Tanques de hidrogênio para residência de Nova Jersey.

Fonte: Hopewellproject, 2012. 
Os cilindros devem ser feitos com placas finas, utilizando materiais altamente resistentes e de excelente durabilidade. Estão classificados basicamente em 4 tipos de acordo com o material utilizado.

Tipo 1: Podem ser feitos totalmente de alumínio ou aço;

Tipo 2: Camada fina de alumínio ou aço envolto por outro composto - geralmente fibras de carbono - em forma de circunferência;

Tipo 3: Fina camada de aço ou alumínio envolto totalmente por outros compostos como fibras de carbono;

Tipo 4: Uma camada de plástico resistente envolto por outro composto também resistente.

Em geral, quanto menos metal for usado, mais leve será o cilindro. Por esta razão, os cilindros com fina camada de aço ou alumínio e com alta resistência, tal como o Tipo 3, são mais usados para aplicações com hidrogênio. Os cilindros do Tipo 4 ganharão mais espaço no mercado futuro. Os cilindros do Tipo 3 utilizam finas camadas de aço ou alumínio intercaladas e envoltas por fibras de carbono, utilizando resinas como o epóxy para colá-las.

A combinação de fibras e resina para envolver as camadas metálicas possibilita uma alta resistência, e diferentemente dos metais, são menos corrosivos, embora possam sofrer danificações devido a impactos, cortes, abrasão, etc.

Um detalhe importante é com relação à temperatura em ambientes quentes, ou devido ao resultado de compressão durante o abastecimento do cilindro, o que faz com que a pressão aumente em $10 \%$ ou mais. Qualquer gás armazenado nestas pressões é extremamente perigoso e capaz de liberar um fluxo de gás com força explosiva ou capaz de impulsionar um pequeno objeto na velocidade de uma bala.

Apesar do perigo em potencial, os cilindros de alta pressão têm uma estatística de segurança excelente. Durante a fabricação, cada cilindro passa por testes de hidrostática e vazamentos, e uma determinada quantidade de cilindros de cada lote são selecionados 
aleatoriamente para testes cíclicos e de explosão. Os cilindros carregam informações como a marca do fabricante, o padrão de construção, número serial, pressão para uso, máxima pressão de abastecimento, e tempo de validade. Os cilindros têm uma vida útil de aproximadamente 15 anos ou 11.250 abastecimentos. Mas deve-se sempre fazer inspeções e testes de vazamentos como parte de uma rotina de manutenção (WICAC, 2012).

2- Na forma líquida

O armazenamento na forma líquida permite uma maior densidade de hidrogênio. A temperatura de liquefação do hidrogênio é da ordem de $20,3 \mathrm{~K}\left(-253^{\circ} \mathrm{C}\right)$. O processo de liquefação de hidrogênio já é bem dominado pela indústria e as unidades de liquefação são fabricadas, por exemplo, pela Linde-Union Carbide (EUA) e a L'Air Liquide (França). Com o uso da tecnologia atual de liquefação são gastos aproximadamente de 9 a 11 kWh.kg-1 de H2 líquido produzido, ou seja, o gasto com energia é alto (SOUZA, 1994). Além disso, o hidrogênio líquido tem que ser armazenado em tanques criogênicos, os quais tem a forma esférica ou cilíndrica e as paredes são metálicas de duplas camadas isoladas entre si, com perdas da ordem de 0,5 a $1 \%$ por dia. Conclui- se que o armazenamento de hidrogênio na forma líquida é limitado pelo alto consumo de energia e investimento nos reservatórios criogênicos (SILVA, 1991; KELLEY, 1975).

\section{3- Compostos intermediários}

O hidrogênio combina-se com a maioria dos elementos químicos e ligações deste tipo formam moléculas com a fórmula geral $\mathrm{RHx}$, sendo $\mathrm{R}$ o elemento, $\mathrm{H}$ o átomo de hidrogênio e $\mathrm{x} O$ número de átomos de hidrogênio (SILVA, 1991). Nos casos de interesse prático calor é desprendido quando o hidreto é formado, ou seja, o processo é exotérmico. Como exemplos de hidretos metálicos tem-se o FeTiH2, MgH2, $\mathrm{LiH}, \mathrm{TiH} 2$ etc. Quando calor é fornecido ao hidreto o hidrogênio é liberado (processo endotérmico). Dependendo do tipo de hidreto, grandes quantidades de hidrogênio são armazenadas por unidade de volume. O hidreto é estocado e transportado em tanques de construção simples. 


\subsubsection{Normas de Segurança}

A principal preocupação na instalação do sistema hidrogênio solar em uma residência é a maneira como esse hidrogênio será estocado, ou seja, a definição de qual solução de estocagem, e o local desse armazenamento.

$\mathrm{O}$ volume físico do reservatório vai depender da quantidade de $\mathrm{H} 2$ produzida diariamente e da pressão na qual este gás será confinado. Inicialmente não está previsto a utilização de um compressor para este gás, adição que certamente permitiria a diminuição do volume físico do reservatório, aumentando o custo do sistema e diminuindo a eficiência global do ciclo. Espera-se que seja possível futuramente a utilização de um gasômetro de maior volume, operando a um a pressão de trabalho um pouco acima da atmosférica, valor adequado para a aplicação a células a combustível.

A quantidade de hidrogênio no reservatório deve garantir uma autonomia de alguns dias, ou seja, a quantidade de dias previamente estipulada no cálculo. Para simular os dias sem insolação, adota-se o valor zero para a quantidade de radiação incidente ao longo do dia no modelo matemático. A atenção a ser tomada é em relação à escolha da pressão, pois ela não deverá ser menor que a pressão de funcionamento da célula a combustível (2 bar) nem maior que a pressão determinada pelo eletrolisador, já que o sistema não contará com um compressor para que se possa atingir maiores pressões (FURLAN, 2008). No trabalho feito no laboratório do hidrogênio em Campinas para a autonomia de 5 dias (com a incidência solar da respectiva cidade) encontrou-se um reservatório com um volume físico de $5 \mathrm{~m}^{3}$ e pressão máxima de 10 bar $(10 \times 105 \mathrm{~Pa})$ como exemplo.

De acordo com ETT in WICAC (2010) as normas de hidrogênio e células a combustível que já são as aplicadas aqui no Brasil:

1. ABNT IEC/TS 622821:2009 - Terminologia. 
2. ABNT ISO/TR 15916:2010 - Considerações básicas para a segurança dos sistemas de hidrogênio.

3. ABNT NBR ISO 14687-1:2010 - Combustível de hidrogênio - Especificação do produto. Parle 1: Todas as aplicações, exceto células a combustível de membrana de troca de prótons (PEM) para veículos rodoviários automotores.

4. ABNT NBR ISO 16110-1:2010 - Geradores de hidrogênio que utilizam tecnologias de processamento de combustível. Parte 1: Segurança.

5. ABNT NBR ISO 17268:2010 - Dispositivos de conexão para reabastecimento de veículos terrestres com hidrogênio comprimido.

6. ABNT NBR IEC 62282-2:2010 - Tecnologia de Célula a Combustível - Parte 2.

\section{Armazenamento em edificações}

Considerando o armazenamento do hidrogênio em cilindros, levou-se em consideração a adição de algumas normas e códigos aplicáveis, tais quais:

1.OSHA - Occupational Safety \& Health Administration (Segurança Ocupacional e Administração Saudável). É um órgão do governo Federal que faz parte do Departamento de Trabalho dos EUA que regula a segurança e saúde nos locais de trabalho.

•1910.101 - Instalações de gases comprimidos.

•1910.103 - Instalações de gases Hidrogênio.

•1910.104 - Instalações de Oxigênio.

2. ABNT - A Associação Brasileira de Normas Técnicas (ABNT) é o órgão responsável pela normalização técnica no Brasil, fornecendo a base necessária ao desenvolvimento tecnológico brasileiro.

•NBR 11725 - Conexões e roscas para válvulas de cilindros para gases comprimidos. 
-NBR ISO 9800-1 - Cilindros para gases.

\section{Local de armazenamento}

a. Os locais de armazenamento de gases comprimidos devem ser sinalizados da seguinte forma para gases combustíveis: "nome do gás - Gás combustível - Não fumar-Evitar chamas" ou equivalente, para oxigênio: “ Oxigênio - Não fumar- Evitar chamas” ou equivalente, para os demais gases somente o nome do gás.

b. O local de armazenamento dos cilindros devem ser adequadamente ventilado e protegido contra irradiação solar.

c. Sistemas de armazenamento dos gases comprimidos devem ser posicionados de modo que seja facilmente acessível substituição e transporte dos cilindros por pessoas autorizadas.

d. Sistemas de armazenamento para gases combustíveis e oxigênio não podem ser localizados sob linhas de energia elétrica.

e. Sistema de armazenamento de Hidrogênio não pode ser instalado próximo de outros gases combustíveis, líquidos inflamáveis e oxigênio.

f. Sistema de armazenamento de Oxigênio não pode ser instalado próximo de outros gases combustíveis e líquidos inflamáveis.

g. O sistema de armazenamento de hidrogênio não ser expostos com outras linhas de combustíveis e oxidantes.

h. O sistema de armazenamento de oxigênio não ser expostos com outras linhas de combustíveis.

i. Construção do abrigo não pode ser utilizada materiais combustíveis deverão ser divididos em abrigos distintos por gás com os requisitos de afastamentos, as paredes são de alvenaria com emboço normal, com laje de cobertura, opcionalmente podem ser utilizadas telhas metálicas com todo material de sustentação metálico, os portões devem ser em estrutura metálica com chave, a área de ventilação deve ser cruzada entre frente e fundo (portões 
vazados e cobogós ao fundo) com telas contra insetos aplicados em todas as aberturas. Deve se previr iluminação no local para serviços noturnos lembrando que para os gases comprimidos e oxidantes a área é classificada.

j. Suportes das redes de gases devem ser aparafusados e absorver vibrações e choques resistentes a produto químicos e corrosivos.

k. Distância de vão entre os suportes devem ser para trechos verticais de 1,8 metros e para trechos horizontais de 1,2 metros.

I. Para posto de utilização deve ser previsto uma válvula reguladora de pressão simples estágio com manômetro para ajustar a pressão de operação.

m. Válvulas reguladoras de posto de utilização devem ser instaladas mais próximas possíveis dos pontos de consumo e identificando o tipo de gás e deve ser composto de um manômetro a sua jusante.

n. As válvulas de posto devem ter acessos fáceis e protegidos contra danos físicos e de manipulação.

o. As válvulas de postos quando não utilizadas devem estar bloqueadas por um dispositivo de vedação em sua saída.

p. Instalação do sistema de hidrogênio deve ser supervisionada por profissionais com conhecimento nos requisitos em relação à construção e a utilização do mesmo.

q. Os instrumentos de medição devem ser calibrados e certificado pela RBC.

r. Dispositivos de segurança devem ser calibrados e certificados pela RBC.

s. As redes depois de construídas devem ser feito a execução do teste de estanqueidade com gás hélio com pressão de teste de 1,5 x PMTA.

Ainda buscando implementar a bibliografia sobre armazenamento de hidrogênio em cilindros, consultou-se a "Ficha de Informações de Segurança de Produtos Químicos" da empresa White Martins que é subsidiária de uma das maiores empresas de gases industriais e 


\section{em residências}

medicinais do mundo, a Praxair. Seu portfólio de produtos inclui gases atmosféricos (oxigênio, nitrogênio e argônio), gases de processo (gás carbônico, acetileno, hidrogênio, misturas para soldagem), gases especiais e medicinais, cilindros de aço sem costura, equipamentos para aplicação, transporte e armazenamento de gases, soluções para o mercado de gás natural, nas áreas de GNV (Gás Natural Veicular), GNC (Gás Natural Comprimido) e GNL (Gás Natural Liquefeito), e tratamento de água e efluentes. O quadro 10 mostra a classificação de gases de acordo com a empresa White Martins, o hidrogênio é classe 2.

\begin{tabular}{|c|c|c|c|}
\hline Grupo & Classificação & Características & Exemplos \\
\hline 1 & Inertes & $\begin{array}{c}\text { Não inflamável, não corrosivo e } \\
\text { baixa toxidez }\end{array}$ & $\begin{array}{l}\text { Argônio, hélio, } \\
\text { nitrogênio, oxigênio }\end{array}$ \\
\hline 2 & Inflamáveis & $\begin{array}{c}\text { Inflamável, não corrosivo, e baixa } \\
\text { toxidez }\end{array}$ & $\begin{array}{l}\text { Butano, etano, } \\
\text { hidrogênio, propano }\end{array}$ \\
\hline 3 & $\begin{array}{l}\text { Inflamáveis corrosivos e } \\
\text { tóxicos }\end{array}$ & Inflamáveis corrosivos e tóxicos & $\begin{array}{l}\text { Oxido de etileno, } \\
\text { brometo de metila }\end{array}$ \\
\hline 4 & Tóxicos e/ou corrosivos & $\begin{array}{l}\text { Toxico e/ou corrosivo e não } \\
\text { inflamável }\end{array}$ & Amônia , cloro, flúor \\
\hline 5 & Pirofóricos & Espontaneamente inflamáveis & Silano \\
\hline 6 & Venenosos & Venenosos & Arsina, oxido nítrico \\
\hline
\end{tabular}

\section{Quadro 10: Classificação de gases.}

Fonte: White Martins, 2014.

A ficha traz informações sobre o hidrogênio, tais quais: Gás inflamável a alta pressão. Pode formar misturas explosivas com o ar. Pode inflamar se a válvula estiver aberta para o ar ambiente. Queima com chama invisível. Pode causar vertigem e sonolência. Equipamento autônomo de respiração pode ser requerido para a equipe de salvamento. Inodoro. Valor Limite de Tolerância (LTV): Asfixiante simples. Contato com os olhos: Nenhum efeito esperado. Contato com a pele: Nenhum efeito esperado. Inalação: Asfixiante. Os efeitos são devido à falta de oxigênio. Concentrações moderadas pode causar dor de cabeça, vertigem, sonolência, excitação, excesso de salivação, vômito e perda da consciência. A falta de oxigênio pode ser fatal. Ingestão: É uma maneira improvável de exposição. Este produto é um gás a temperatura e pressão normais. O Hidrogênio é um asfixiante. A falta de oxigênio pode levar a morte. As propriedades toxicológicas, físicas e químicas do hidrogênio indicam que a superexposição é improvável de agravar as condições clínicas existentes. 
1)Medidas de Primeiros Socorros:

CONTATO COM OS OLHOS: Imediatamente banhe os olhos com água corrente durante 15 minutos no mínimo. Mantenha as pálpebras abertas e longe do globo ocular para assegurar que toda a superfície seja completamente enxaguada. Chame um médico imediatamente, de preferência um oftalmologista.

CONTATO COM A PELE: Lave com água e sabão. Se a irritação persistir procure um médico imediatamente.

INALAÇÃO: Remova para ar fresco. Aplique respiração artificial, se não estiver respirando. Oxigênio deve ser administrado por uma pessoa qualificada se houver dificuldade de respirar. Chame um médico imediatamente.

INGESTÃO: É uma maneira improvável de exposição. Este produto é um gás a temperatura e pressão normais.

NOTAS AO MÉDICO: Não há antídoto específico. Tratamento da superexposição deve ser dirigido para o controle dos sintomas e condições clínicas do paciente.

2)Medidas de Combate a Incêndio:

Meio de combate ao fogo: $\mathrm{CO} 2$, pó químico seco, jatos de água em forma de neblina.

Procedimentos especiais de combate ao fogo: Gás inflamável à alta pressão. Retire todo o pessoal da área de risco. Imediatamente resfrie os recipientes com jatos de água em forma de neblina mantendo-se a uma distância segura, tomando cuidado para não extinguir as chamas. Remova todas as fontes de ignição se não houver risco. Remova todos os recipientes da área de fogo, se não apresentar risco, enquanto continua resfriando com jatos de água. Não extinga as chamas emitidas pelos recipientes, interrompa o vazamento de gás se não houver risco, deixe as chamas queimarem completamente. Equipamento autônomo de respiração pode ser requerido para a equipe de salvamento. Brigadas de incêndio locais devem estar cientes das características do produto. Possibilidades incomuns de incêndio: Gás inflamável. A chama é 
quase invisível. O escapamento de gás pode inflamar espontaneamente. O hidrogênio tem baixa energia de ignição. Uma bola de fogo é formada se a nuvem de gás for inflamada imediatamente após o escape. Forma misturas explosivas com o ar e agentes oxidantes. O calor do fogo pode aumentar a pressão dentro do cilindro, e, consequentemente, causar ruptura. Nenhuma parte do recipiente deve ser sujeita a temperaturas mais altas que $52{ }^{\circ} \mathrm{C}$ (aproximadamente $125^{\circ} \mathrm{F}$ ). Alguns recipientes são providos com dispositivo de alívio de pressão projetado para aliviar o conteúdo quando eles são expostos a temperaturas elevadas. Se o vazamento pegar fogo, não extinga as chamas. Gás inflamável pode ser liberado no vazamento, criando uma atmosfera de reignição explosiva. Os vapores formados deste produto podem ser transportados por correntes de ar e ser incendiados por luzes-piloto, outras chamas, cigarros, faíscas, aquecedores, equipamentos elétricos, descargas estáticas e outras fontes de ignição localizadas a distância do ponto de manuseio do produto. Atmosferas explosivas podem se prolongar. Antes de entrar em áreas, principalmente confinadas, teste a atmosfera com dispositivo apropriado (ex. explosímetro). Produtos passíveis de combustão: Nenhum conhecido.

\section{3)Medidas de Controle para Derramamento / Vazamento}

Medidas a tomar se o material derramar ou vazar: PERIGO! Gás inflamável à alta pressão. Forma misturas explosivas com o ar. Evacue imediatamente todo o pessoal da área de risco. Use equipamento autônomo de respiração quando necessário. Remova todas as fontes de ignição, se não houver risco. Reduza vapores com neblina ou jatos finos de água. Interrompa o vazamento se não houver risco. Ventile a área do vazamento ou remova os recipientes com vazamento para áreas bem ventiladas. Vapores inflamáveis podem se propalar do vazamento. Antes de entrar em áreas, principalmente confinadas, teste a atmosfera com dispositivo apropriado (ex. explosímetro). Método para a disposição de resíduos: Previna o resíduo de contaminar o ambiente ao redor. Mantenha o pessoal distante. Descarte qualquer produto, resíduo, recipiente disponível de maneira que não prejudique o meio ambiente, em total obediência às regulamentações Federais, Estaduais e Locais. Se necessário, entre em contato com seu fornecedor, para assistência. 
4)Manuseio e Armazenamento

Condições de armazenamento: Armazene e use com ventilação adequada. Mantenha os cilindros de Hidrogênio longe de oxigênio, cloro e outros oxidantes a uma distância mínima de 6,1 m (20 ft), ou use uma barragem de material não combustível. Essa barragem deve ter no mínimo $1,53 \mathrm{~m}$ de altura $(5 \mathrm{ft})$ e ser resistente ao fogo por pelo menos $1 / 2$ hora. Assegure-se de que os cilindros estejam fora de risco de queda ou roubo. Atarraxe firmemente o capacete com as mãos. Identifique a área de armazenamento e uso com placas "NÃO FUME OU ABRA CHAMAS". Não devem existir fontes de ignição no local. Todos os equipamentos elétricos na área de estocagem devem ser a prova de explosão. As áreas de estocagem devem ter códigos nacionais de eletricidade para Classe 1 em áreas de risco. Não permita estocagem em temperaturas maiores que $52^{\circ} \mathrm{C}$. Armazene separadamente os cilindros cheios dos vazios. Use um sistema de fila, para prevenir o estoque de cilindros cheios por longos períodos. Precauções de manuseio: Proteja os cilindros contra danos físicos. Utilize em carrinho de mão para movimentar os cilindros; não arraste, role, ou deixe-o cair. Todos os sistemas de tubulações de hidrogênio e equipamentos associados devem ser aterrados. Equipamentos elétricos não podem ser lança chamas, e devem ser a prova de explosão. O controle de escapamento deve ser feito com água e sabão, nunca use fogo. Nunca tente levantar um cilindro pelo capacete; o capacete existe apenas proteger a válvula. Nunca insira qualquer objeto (ex. chave de parafuso, chave de fenda) dentro da abertura do capacete; isto pode causar dano a válvula, e consequentemente um vazamento. Use uma chave ajustável para remover a correia da chave de parafuso e remover capacetes justos ou enferrujados. Abra a válvula suavemente. Se estiver muito dura, descontinue o uso e entre em contato com seu fornecedor. Não atinja um cilindro de gás comprimido com arcos. Nunca aterre o cilindro, ou permita que este faça contato com um circuito elétrico.

5)Controle de Exposição e Proteção Individual 
Proteção Respiratória (Tipo Específico): Nenhum requerido para uso normal. Um equipamento autônomo de respiração dever utilizado em espaço confinado.

Ventilação:

Exaustão Local: Um sistema de exaustão à prova de explosão deve ser utilizado.

Mecânica (Geral): Use apenas em sistema fechado.

Especiais: Inadequado.

Luvas Protetoras: Use luvas de raspa para manusear cilindros.

Proteção dos Olhos: Óculos de segurança, modelo ampla visão.

Outros Equipamentos Protetores: Sapatos de segurança com biqueira de aço para manuseio de cilindros. Outros equipamentos onde necessário. Mesmo com todo o equipamento protetor, nunca toque partes elétricas energizadas.

6)Estabilidade e Reatividade

Estabilidade: Estável.

Incompatibilidade (Materiais a Evitar): Agentes oxidante, Lítio e halogênios.

Produtos Passíveis de Risco Após a Decomposição: Nenhum.

Risco de Polimerização: Não Ocorrerá.

Condições de evitar: Nenhuma conhecida.

Informações Toxicológicas: Hidrogênio é um asfixiante simples.

7) Informações Ecológicas

Não é esperado nenhum efeito ecológico. Este produto não contém nenhum material químico das Classes I ou II (destruidores da camada de ozônio). O hidrogênio não é considerado como poluente marítimo pelo DOT.

8)Considerações sobre Tratamento e Disposição 


\section{em residências}

Método de disposição de resíduos: Não tente desfazer-se de resíduos ou quantidades não utilizadas. Devolva o cilindro ao seu fornecedor.

INFORMAÇÕES ESPECIAIS DE EMBARQUE: Os cilindros devem ser transportados em posição vertical, em veículo com ventilação. Cilindros transportados em veículo enclausurado, em compartimento não ventilado podem apresentar sérios riscos a segurança. Assegure-se de ler e compreender todas as etiquetas e outras instruções fornecidas em todos os recipientes deste produto.

PRECAUÇÕES ESPECIAIS: Gás inflamável à alta pressão. Use tubulação e equipamentos adequadamente projetados para resistiram às pressões que possam ser encontradas. Use apenas em sistema fechado. Só utilize ferramentas a prova de faíscas e equipamentos a prova de explosão. Mantenha longe do calor, faíscas e abre-chamas. Previna fluxo reverso. Fluxo reverso no cilindro pode causar ruptura. Use uma válvula de segurança ou outro dispositivo na linha ou tubulação do cilindro. O gás pode causar sufocamento rápido devido à insuficiência de oxigênio. Armazene e utilize com ventilação adequada. Feche a válvula após cada uso, e mantenha fechada mesmo quando o cilindro estiver vazio. Nunca trabalhe em um sistema pressurizado. Se houver vazamento, ventile o sistema de maneira a obedecer todas as leis federais, estaduais e locais, então repare o vazamento. Nunca aterre um cilindro de gás comprimido, ou permita que este faça parte de um circuito elétrico (WHITE MARTINS, 2006).

A OSHA (Occupational Safety and Health Association) publica normas de armazenamento de gás hidrogênio. O não cumprimento destas disposições pode resultar em multas e penalidades. A OSHA regula os recipientes de armazenamento em que o hidrogênio pode ser transportado. Os recipientes devem ser claramente marcados para indicar o seu conteúdo e contêm válvulas de segurança. Os dispositivos devem descarregar para cima e projetado de forma a evitar a possibilidade de umidade congelamento e obstrução do sistema de alívio. Os recipientes de hidrogênio não podem ser localizados perto de linhas de energia elétrica, tubulação de líquido inflamável ou tubulação para outros gases inflamáveis. Eles devem 
ser armazenados acima do solo e, acima de sistemas de armazenamento de líquidos inflamáveis, a menos que a prevenção do acúmulo de líquidos for contabilizada. Enumera a distância mínima que deve ser armazenada os cilindros, a partir de estruturas circundantes, com base no volume de hidrogênio armazenado em centímetros cúbicos.

O Manual de Segurança em Laboratórios Químicos - Instituto de Pesquisas energéticas e Nucleares IPEN, também prevê algumas normas para ambientes de laboratórios, mas pode-se aplicar em qualquer tipo de edificação. Os gases comprimidos podem ser classificados como gases liquefeitos, gases não liquefeitos e gases em solução. Todos apresentam um risco potencial no laboratório, devido à pressão dentro dos cilindros e ainda sua flamabilidade e toxidez.

Os gases comprimidos são fornecidos aos laboratórios em cilindros de diversas capacidades. Os cilindros devem ser manipulados com cuidado para prevenir que sejam derrubados ou atinjam outros objetos. Todos os cilindros que não estejam em uso devem estar com a cápsula protetora da válvula. Quando os cilindros de baixa pressão são fornecidos sem cápsula protetora da válvula, devem ser providenciados outros suportes ou garras que evitem a queda do cilindro pondo em risco a integridade da válvula. Sendo a válvula do cilindro arrancada ou o cilindro rompido de alguma forma, pode o gás impelir o cilindro com muita força e causar sérios acidentes. Os cilindros devem ser identificados e estocados em áreas bem ventiladas e livres de materiais inflamáveis. Os cilindros estocados ao ar livre devem ser protegidos contra variações excessivas na temperatura ambiente e de contato direto $\mathrm{cm}$ o chão. Possíveis corrosões externas no cilindro causadas por líquidos ou vapores corrosivos devem ser evitadas.

Os cilindros de gases comprimidos devem ser estocados na posição vertical e garantidos contra eventuais quedas. Os cilindros cheios devem ficar separados dos cilindros vazios. Se o espaço para estocagem exigir que os cilindros contendo gases de diferentes tipos sejam estocados juntos, deve-se ao menos agrupá-los por tipo de gás. Os gases inflamáveis devem ser separados dos gases oxidantes usando os cilindros dos gases não combustíveis. Sendo possível, os cilindros de gases inflamáveis e oxigênio devem ser mantidos fora dos prédios e 
distribuídos por sistemas de tubulação até os locais de uso.É importante que algumas das propriedades dos gases comprimidos, que representam perigos (como inflamabilidade, toxidez, atividade química e efeitos corrosivos) sejam bem conhecidos pelos usuários do gás. Na capela de um laboratório, em presença de chama aberta, a inflamabilidade do Monóxido de Carbono pode ser o maior risco, ao passo que uma fábrica-piloto usando Monóxido de Carbono como reagente, um vazamento e em consequência, a toxidez possa representar o maior risco. É interessante notar, que pequenas concentrações de gases liquefeitos de petróleo como o butano e o propano são suficientes para a criação de misturas inflamáveis. As faixas de inflamabilidade do Acetileno, Monóxido de Carbono, Hidrogênio e Sulfeto de Hidrogênio são extremamente grandes, indicando que eles podem formar misturas explosivas com o ar sob uma extensa faixa de concentração (IPEN, 2012). De acordo com Araújo (2005), os cilindros são vasos de pressão utilizados para acondicionar e transportar gases. As partes que compõem um cilindro são: base, calota (ou ogiva), capacete (ou cúpula), colarinho, corpo, fundo, gargalo e pé. Eles possuem características construtivas próprias, variando de acordo com o gás e pressão operacional. Para a identificação dos gases, o Regulamento de Transporte de Produtos Perigosos e o Código de Defesa do Consumidor apud Araújo (2005), determinam que todas as embalagens devem conter informações sobre os riscos inerentes e forma de acondicionamento. Uma das formas de identificação é a cor do cilindro. O quadro 11 mostra as cores dos cilindros para os gases mais comuns.

\begin{tabular}{|c|c|c|}
\hline Gás & Formula química & Cor \\
\hline Oxigênio medicinal & $\mathrm{O}_{2}$ & Verde \\
\hline Oxigênio industrial & $\mathrm{O}_{2}$ & Preto \\
\hline Nitrogênio & $\mathrm{N}_{2}$ & Cinza \\
\hline Hidrogenio & $\mathrm{H}_{2}$ & Amarelo \\
\hline Hélio & $\mathrm{He}$ & Laranja \\
\hline Metano & $\mathrm{CH}_{4}$ & Rosa claro \\
\hline Gás cloro & $\mathrm{Cl}_{2}$ & Laranja com faixa cinza \\
\hline
\end{tabular}

Quadro 11: Cores de cilindros para os gases mais comuns.

Fonte: Araújo (2005, p. 398). 


\section{Armazenagem de cilindros}

Os locais de armazenamento de cilindros devem ser locais seguros, devido ao grau de risco que eles apresentam. Por isso, algumas medidas de seguranças devem ser tomadas como menciona Araújo (1975).

a) Não deixar os cilindros ao relento: na impossibilidade de armazená-los no interior dos almoxarifados, galpões ou depósitos, dever-se-á protegê-los, de dia, dos raios diretos do sol, pois um aquecimento demasiado poderá causar serio acidente devido ao aumento de pressão dentro dos cilindros; de noite terão de ser abrigados contra o orvalho, pois a ferrugem diminui a resistência à pressão.

b) Não deixar os cilindros em locais onde possam ser danificados, nem perto de óleo, graxa, palhas ou outros materiais inflamáveis ou combustíveis, nem junto a fontes de calor;

c) Sinalizar o local, com placas de advertência: "Proibido fumar", "inflamável", entre outras. Sinalizar os cilindros cheios dos vazios; entre outras.

As figuras 15 e 16 ilustram a forma ideal de armazenamento dos cilindros de hidrogênio.

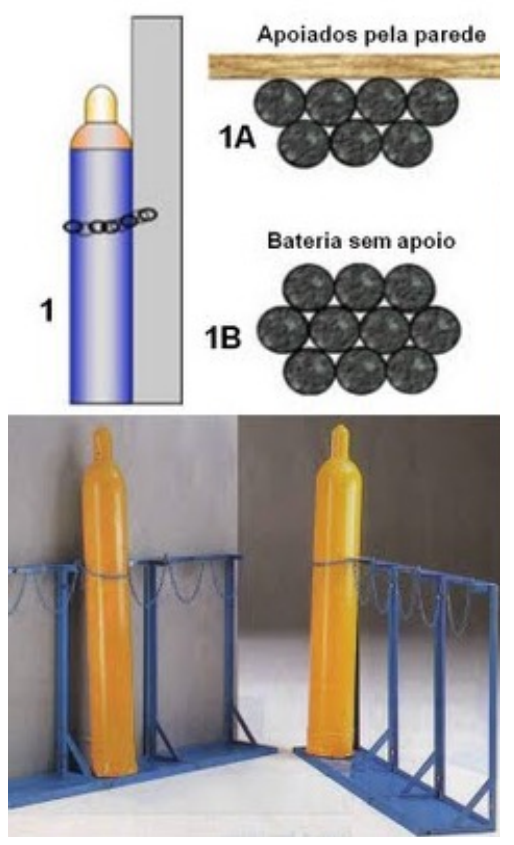

Figura 15: Cores e locação de cilindros para os gases mais comuns.

Fonte: Araújo, 2005. 


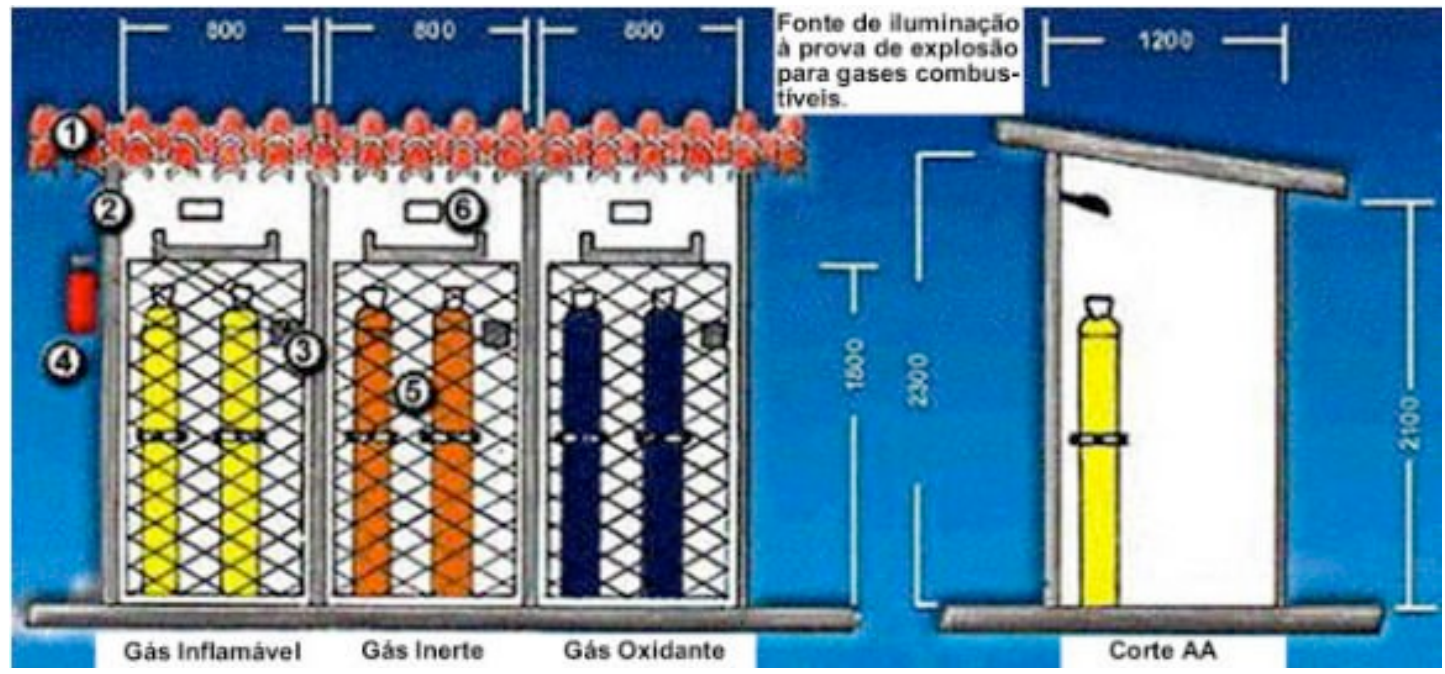

1. Cobertura

2. Separação do ambiente externo

3. Parede "Corta-Fogo"

4. Extintor de incêndio

5. Correntes de Fixação

6. Identificação dos gases e seus riscos

Figura 16: Locação de cilindros com gases.

Fonte: Silva, 1992.

\section{Movimentação de cilindros}

Como os cilindros são vasos de pressão bastante resistentes, pesados e acondiciona gases sob pressão sua movimentação deve ser feita com muito cuidado. Araújo $(2005$, p. 409) e Araújo (1975, p.176) estabelecem alguns princípios para a segurança na movimentação.

a) Ao mover cilindros com guindastes ou pontes rolantes deve-se empregar sempre um bom berço, caçamba ou plataforma, nunca utilizando ligas ou eletroímãs; b) Devem-se usar carrinhos adequados para movimentá-los, tais como carrinho americano, provido de rodas de borracha e alças de couro para a fixação dos cilindros; c) Fechar sempre as válvulas antes de movimentar os cilindros, a menos que eles estejam bem colocados em um carro, remover as válvulas reguladoras e atarrachar às tampas de proteção; d) Nunca transportar os cilindros em 
veículos untados com óleo ou graxa, devido ao perigo de explosão; e) Nunca servir-se das tampas de proteção para suspender os cilindros verticalmente do chão, pois elas não se destinam a tal fim; para mudar os cilindros da posição horizontal para a vertical, ou vice e versa, deve-se estar seguro de que a tampa está no lugar e bem atarraxada; depois, segurá-la firmemente com as mãos e dar movimento desejado ao cilindro; f) Jamais empregar os cilindros como roletes ou suportes, mesmo que eles estejam vazios, para que não se danifiquem; entre outras. A figura 17 mostra a classificação e rotulagem de perigo dos gases.

\begin{tabular}{|c|c|}
\hline & Risco \\
\hline & Saúde \\
\hline & flamabilidade \\
\hline & Reatividade \\
\hline & erigo Especial \\
\hline OXY & Agente Oxidante \\
\hline ACID & Ácido \\
\hline ALK & Álcalis \\
\hline COR & Corrosivo \\
\hline W & Reação com água \\
\hline 8 & Radioativo \\
\hline
\end{tabular}

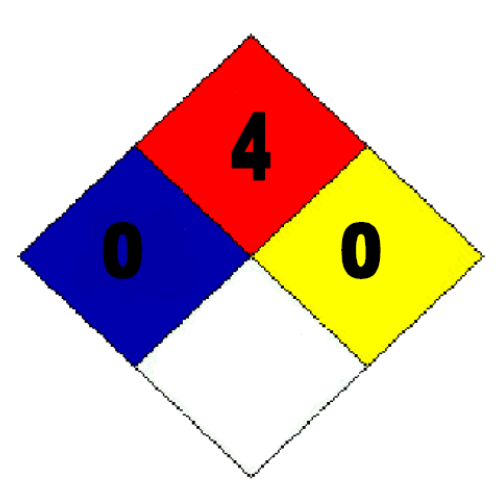

Grau

\begin{tabular}{|ll|}
\hline 4 & Extremo \\
\hline 3 & Grave \\
\hline 2 & Moderado \\
\hline 1 & Leve \\
\hline 0 & Mínimo \\
\hline
\end{tabular}

Figura 17: Classificação e rotulagem de perigo.

Fonte: Ficha técnica linde gás, 2014.

\subsection{CÉLULAS A COOBUSGÍVEL}

A célula a combustível serve como o "motor" do sistema, que é abastecido pelo combustível hidrogênio, fazendo uma analogia ao processo de geração de energia pelos motores a gasolina.

As células a combustível $(\mathrm{CaC})$ são dispositivos que convertem energia química de certos combustíveis diretamente em energia elétrica, térmica (calor) e água. Nesse processo não há a combustão. Os combustíveis usados nas células podem ser o hidrogênio, gás natural, etanol, metanol, entre outros (CGEE, 2002). 
As células a combustível são similares às baterias convencionais, que fornecem eletricidade em corrente contínua a partir de uma reação química. No entanto, as baterias convencionais precisam ser recarregadas, ao contrário das células a combustível, que fornecem energia elétrica indefinidamente enquanto forem abastecidas por um combustível (CGEE, 2002).

De acordo com RIFKIN (2003) a descoberta das CaCs antecede a do motor de combustão interna, sendo relatada pela primeira vez em 1839 pelo britânico William Grove. A "bateria voltaica gasosa" como era chamada, convertia diretamente a energia química do hidrogênio e oxigênio em energia elétrica na forma de corrente contínua, utilizando um ânodo e um cátodo de platina imersos em ácido sulfúrico. A descoberta foi baseada na reversibilidade termodinâmica da eletrólise da água, cuja reação é demonstrada a seguir:

$$
\mathrm{H}_{2} \mathrm{O}+\text { eletricidade } \leftrightarrow \mathrm{H}_{2}+1 / 2 \mathrm{O}_{2}
$$

\subsubsection{Funcionamento da Célula a Combustível}

O princípio de funcionamento das células a combustível está baseado em reações eletroquímicas onde ocorre a oxidação direta de um combustível (mais comum é o hidrogênio) e a de redução de um oxidante (mais comum o oxigênio). O hidrogênio se oxida no ânodo produzindo elétrons e prótons. O próton migra através do eletrólito na direção do cátodo. Os elétrons circulam por um circuito externo na direção do cátodo. No cátodo ocorre a formação de água (UTC FUEL CELLS, 2008). Veja a seguir a figura 18 ilustrando o funcionamento de uma célula. 


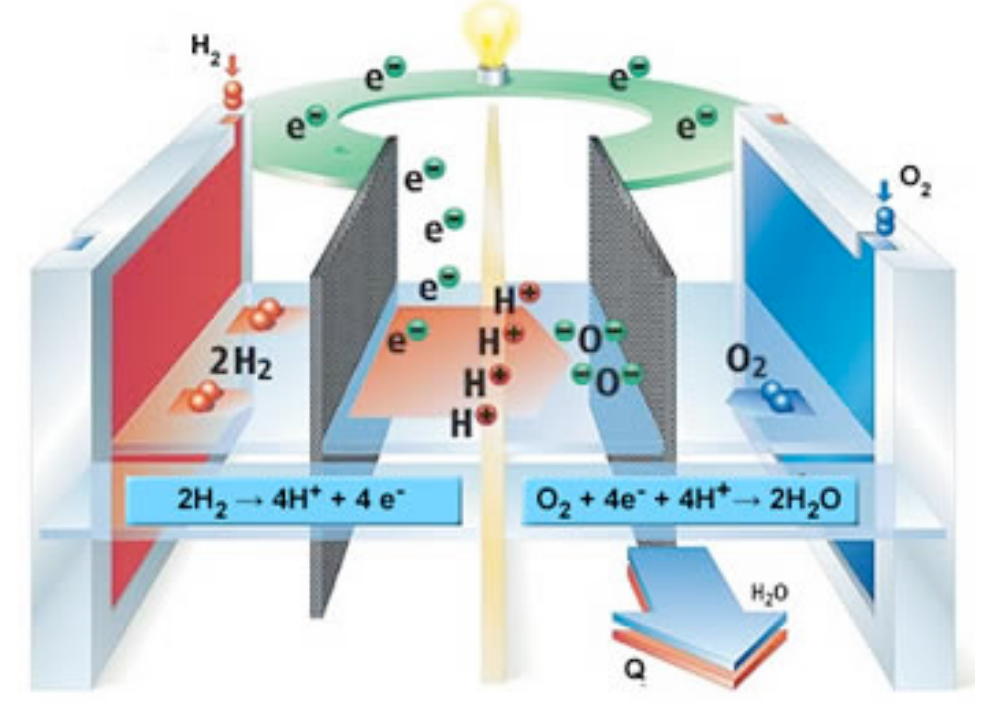

Figura 18: Funcionamento de uma Célula a Combustível.

Fonte: IPEN, 2009. Disponível em

<http://www.ipen.br/sitio/?idm=59> Acesso em 7 out. 2013.

\section{Partes de uma célula à combustível (do tipo PGW)}

1. Ânodo - pólo negativo da $\mathrm{CaC}$ que desempenha vários papéis. É onde ocorre a oxidação do hidrogênio gasoso, onde os íons $\mathrm{H}+$ resultante dessa reação é transportado via eletrólito até o cátodo, e os elétron oriundos da reação alcançam o catodo por um circuito externo originando assim uma corrente elétrica.

2. Cátodo - enquanto isso o catodo, pólo positivo da célula a combustível, recebe os íons $\mathrm{H}+$, advindos do anodo, que recombinam com o oxigênio e os elétrons da corrente externa, através de uma reação eletroquímica para formar água.

3. Eletrólito - é a membrana trocadora de prótons. A membrana se comporta como eletrólito responsável por transportar o íons $\mathrm{H}+$ do anodo para o catodo. Ela é um isolante elétrico. A membrana mais comum é um politetrafluoretileno dopado com grupos sulfônicos onde os prótons estão localizados.

4. Catalisador - é um material especial que facilita a reação entre o oxigênio e o hidrogênio. Geralmente é feito de pó de platina de alta área superficial suportada em 
papel de carbono poroso ou tecido. Dessa maneira é possível maximizar área superficial da platina seja exposta ao hidrogênio e ao oxigênio. A face do catalisador fica em exposto a membrana condutora.

5. O Conjunto - a potencia é determinada pela quantidade de células empilhadas e pela suas respectivas áreas dos eletrodos. Usualmente as células a combustível são montadas no modelo filtro prensa utilizando placas separadoras bipolares, que de um lado circula o hidrogênio e do outro o oxigênio. Cada célula empilhada produz aproximadamente 0,6Volts em densidade de corrente de $0,3 \mathrm{~A} / \mathrm{cm}^{2}$. (CHBC, 2008). As partes de uma célula a combustível podem ser vistas na figura 19.

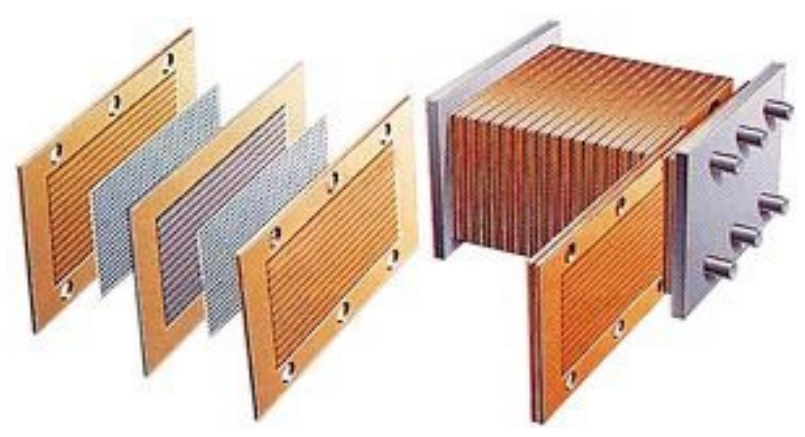

Figura 19: Partes de uma célula a combustível.

Fonte: Gonzalez, 2002 - WiCaC 2002.

As características ideais das placas são: boa condutividade eletrônica e térmica; impermeabilidade ao hidrogênio, oxigênio e água; resistência mecânica para suportar compactação; neutralidade química; baixo custo; resistência a temperatura de operação da célula; pouca espessura possibilitando canais de fluxo gasosos de ambos os lados sem que ocorram vazamentos externos (CONTADINI, 2002).

\section{Reações químicas que acontecem na CaC:}

Lado do ânodo: $2 \mathrm{H}_{2}=>4 \mathrm{H}++4 \mathrm{e}-$

Lado do cátodo: $\mathrm{O}_{2}+4 \mathrm{H}++4 \mathrm{e}-=>2 \mathrm{H}_{2} \mathrm{O}$

Reação líquida: $2 \mathrm{H}_{2}+\mathrm{O}_{2}=>2 \mathrm{H}_{2} \mathrm{O}$ 
Como pode ser observado acima o funcionamento da célula a combustível é produzir energia baseado em reações eletroquímicas não havendo processo de queima como ocorre nos processos a combustão interna. Ao contrário das baterias eletroquímicas, a energia química é armazenada fora da célula onde ocorre a reação.

Uma vez que o combustível é convertido diretamente em eletricidade a CaC pode operar com eficiência maior quando comparadas com os motores a combustão interna que passam sob o Ciclo de Carnot (UTC FUEL CELLS, 2008).

Diferente das baterias convencionais as células a combustível não acumulam energia, apenas transformam o hidrogênio e o oxigênio através de uma reação eletroquímica formando água, energia e calor. Portanto não é emitido nenhum gás prejudicial à atmosfera, como na queima de combustíveis fósseis que emitem monóxido de carbono, óxidos de enxofre, hidrocarbonetos, material particulado, entre outros, auxiliando o aquecimento global.

Existem vários tipos de células em diferentes estágios de desenvolvimento e cada célula contém uma específica finalidade. Elas podem ser Alguns tipos de células já estão sendo abandonados de estudos, por exemplo, a AFC, devido a sua sensibilidade a impurezas (necessita de hidrogênio puro) ou problemas de durabilidade. Já as células PEM, SOFC, PAFC, MCFC estão em ritmo acelerado de desenvolvimento chegando até a serem comercializadas atualmente (DOE, 2008).

O trabalho de mestrado PINTO (2009) apresentou como um dos resultados que o melhor tipo de célula a combustível estacionária para aplicação residencial seria a tipo PEM (polímero solido) que trabalha a baixas temperaturas e é produzida pelas empresas brasileiras dessa tecnologia. O quadro 12 mostra os tipos de células e suas características principais. 


\begin{tabular}{|c|c|c|c|c|c|}
\hline \multicolumn{6}{|c|}{ TIPOS DE CÉLULAS A COMBUSTÍVEL } \\
\hline Tipo & $\begin{array}{c}\text { Eletrólito } \\
\text { (espécie } \\
\text { transportada) }\end{array}$ & $\begin{array}{c}\text { Temperatura } \\
\text { de } \\
\text { funcionamento } \\
\left({ }^{\circ} \mathrm{C}\right)\end{array}$ & Vantagens & Desvantagens & Aplicações \\
\hline $\begin{array}{l}\text { Alcalina } \\
\text { (AFC) }\end{array}$ & $\begin{array}{l}\mathrm{KOH} \\
\left(\mathrm{OH}^{+}\right)\end{array}$ & $60-90$ & $\begin{array}{l}83 \% \text { - alta } \\
\text { eficiência }\end{array}$ & $\begin{array}{l}\text { Sensível a CO2, } \\
\text { gases ultra puros, } \\
\text { sem reforma do } \\
\text { combustível. }\end{array}$ & $\begin{array}{c}\text { Espaçonaves, } \\
\text { aplicações } \\
\text { militares. }\end{array}$ \\
\hline $\begin{array}{l}\text { Membrana } \\
\text { (PEMFC) }\end{array}$ & $\begin{array}{c}\text { Membrana } \\
\left(\mathrm{H}^{+}\right)\end{array}$ & $80-90$ & $\begin{array}{l}60 \% \text { - Alta } \\
\text { eficiência, } \\
\text { operação } \\
\text { flexível. }\end{array}$ & $\begin{array}{c}\text { Custo da } \\
\text { membrana, fácil } \\
\text { contaminação do } \\
\text { catalisador com } \\
\text { CO. }\end{array}$ & $\begin{array}{c}\text { Veículos, } \\
\text { mobilidade, } \\
\text { estacionárias } \\
\text { espaçonaves. }\end{array}$ \\
\hline $\begin{array}{l}\text { Acido } \\
\text { Fosfórico } \\
\text { (PAFC) }\end{array}$ & $\begin{array}{l}\mathrm{H}_{3} \mathrm{PO}_{4} \\
\left(\mathrm{H}_{3} \mathrm{O}^{+}\right)\end{array}$ & $160-200$ & $\begin{array}{c}\text { Em maior } \\
\text { estágio de } \\
\text { desenvolvimento }\end{array}$ & $\begin{array}{l}\text { Controle da } \\
\text { porosidade, } \\
\text { sensível, } \\
\text { corrosível. }\end{array}$ & $\begin{array}{c}\text { Estacionárias, } \\
\text { cogeração }\end{array}$ \\
\hline $\begin{array}{l}\text { Carbonato } \\
\text { fundido } \\
\text { (MCFC) }\end{array}$ & $\begin{array}{l}\text { Carbonatos } \\
\text { fundidos } \\
\left(\mathrm{CO}_{3}{ }^{-}\right)\end{array}$ & $650-700$ & Tolerância a CO & $\begin{array}{l}\text { Problema de } \\
\text { materiais, } \\
\text { necessidade de } \\
\text { reciclagem de } \\
\text { CO2, difícil } \\
\text { controle. }\end{array}$ & $\begin{array}{c}\text { Estacionárias } \\
\text { cogeração }\end{array}$ \\
\hline $\begin{array}{l}\text { Cerâmicas } \\
\text { (SOFC) }\end{array}$ & $\begin{array}{c}\mathrm{ZrO}_{2} \\
\left(\mathrm{O}^{2-}\right) \\
\text { Oxido sólido }\end{array}$ & $800-900$ & $\begin{array}{l}\text { Alta eficiência, a } \\
\text { reforma do } \\
\text { combustível } \\
\text { pode ser feito na } \\
\text { célula. }\end{array}$ & $\begin{array}{c}\text { Problemas de } \\
\text { materiais, } \\
\text { expansão térmica. }\end{array}$ & $\begin{array}{c}\text { Estacionárias, } \\
\text { cogeração }\end{array}$ \\
\hline
\end{tabular}

Quadro 12: Características das células a combustível (ETT in WICAC, 2010).

Fonte: adaptado Linard, 1999.

\section{As células a combustível no Brasil}

O Brasil apresenta grandes oportunidades para a criação de uma infra-estrutura baseada no hidrogênio, energias renováveis e células a combustível, pois é um país com abundância em sol, vento, água, e fácil acesso ao mar. Além disso, o país possui forte investimento no etanol da cana de açúcar, que pode servir também de fonte para o hidrogênio.

Por estas razões, algumas instituições brasileiras já estão pesquisando e desenvolvendo células a combustível e equipamentos para produção de hidrogênio. O país já possui células a combustível, importadas e nacionais, instaladas para fornecer energia de backup em alguns 
hospitais e centros de dados desde 2001. Também existem projetos de ônibus e protótipos de automóveis movidos por células a combustível sendo pesquisados ou em desenvolvimento.

No entanto, o governo brasileiro possivelmente não investirá no desenvolvimento de veículos de pequeno porte movidos por células a combustível, pois as grandes empresas automobilísticas internacionais já estão desenvolvendo e investindo bilhões de dólares. Com isso ocorrerá a importação de boa parte da tecnologia de células a combustível para aplicação automobilística. Apesar disso, temos que desenvolver a tecnologia de infraestrutura para estes automóveis, como postos de combustíveis, eletrolisadores e grandes reformadores de etanol para a produção de hidrogênio.

As tecnologias de células a combustível mais pesquisadas no Brasil são a PEMFC (membrana de troca de prótons) e a SOFC (célula a combustível de óxido sólido), sendo que a tecnologia PEMFC nacional já está bem mais avançada que a SOFC. As pesquisas com etanol estão voltadas principalmente à reforma deste combustível para obtenção de hidrogênio.

Em 2005 o Ministério de Minas e Energia entregou ao IPHE (Parceria Internacional Para a Economia do Hidrogênio) um "Roteiro para a Estruturação da Economia do Hidrogênio no Brasil", com foco em pesquisa e desenvolvimento e de responsabilidade do Ministério da Ciência e Tecnologia (MCT). O MCT investiu de 2004 a 2007, aproximadamente 29 milhões de Reais no "Programa de Ciência, Tecnologia e Inovação para a Economia do Hidrogênio", antigo PROCAC (Programa de Células a Combustível) (NETO, 2007).

Na cidade de Curitiba, três células a combustível de 200 kW estão instaladas em três diferentes locais. Uma delas, instalada no Hospital Erasto Gaertner, centro de referência no tratamento do câncer na região Sul. Já no Hospital Erasto Gaertner, o gás natural é canalizado e o hidrogênio liberado pelo processo de "reforma a vapor", que ocorre dentro da célula a combustível de 200 kW (ASSOCIAÇÃO BRASILEIRA DE INSTITUIÇÕES FILANTRÓPICAS DE COMBATE AO CÂNCER, ABIFCC, 2009). 


\section{em residências}

Além de suprir em torno de $85 \%$ das necessidades de iluminação do hospital, o gerador fornece água quente para cozinha, quartos e banhos. O projeto é financiado pela Copel (Companhia Paranaense de Energia) e a manutenção e operação realizada pelo Lactec (Instituto de Tecnologia para o Desenvolvimento). O gás natural é fornecido pela Compagás, empresa de distribuição de gás. A figura 20 mostra as instalações da célula no hospital:

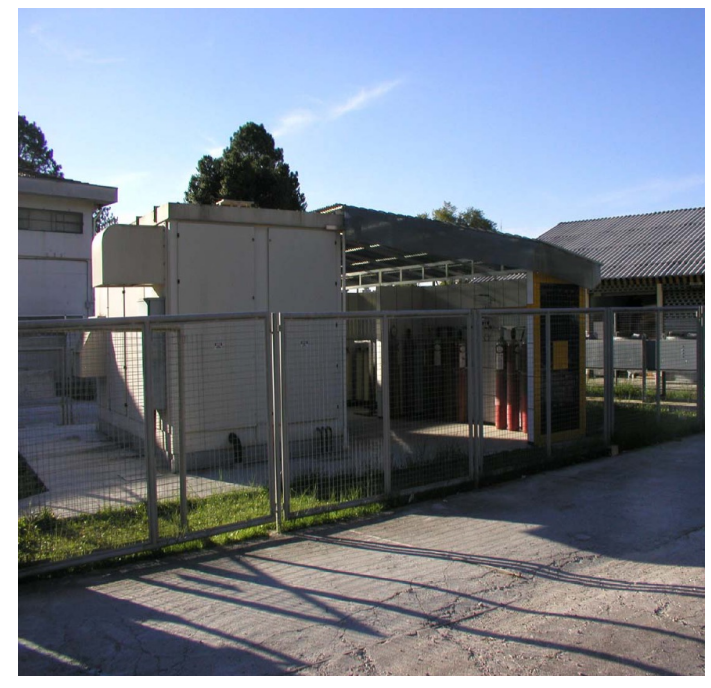

Figura 20: Célula do hospital Erasto Gaertner

Fonte: PORTALH2, 2012. Disponível em <http://www.portalh2.com.br/prtlh2/images/artigos/a39.pdf> Acesso em 9 out. 2013.

As figuras 21 e 22 mostram a célula PAFC instalada nas dependências da COPEL e LACTEC respectivamente.

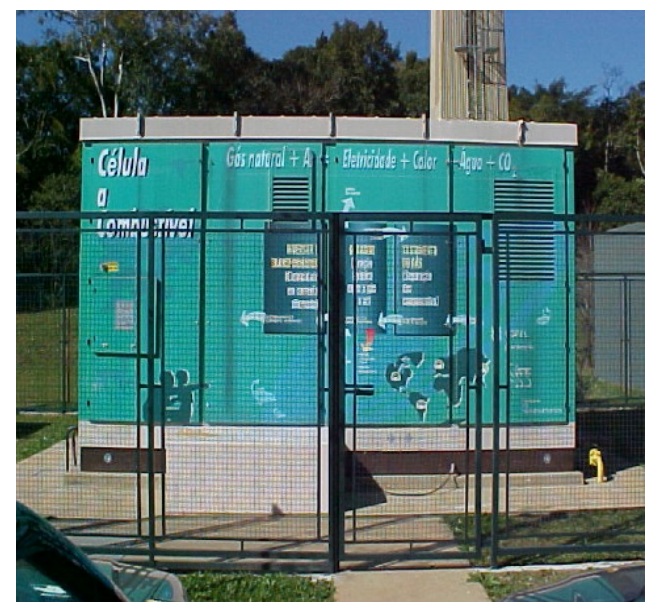

Figura 21: célula da COPEL

Fonte: PORTALH2, 2012. <http://www.portalh2.com.br/prtlh2/images/artigos/a39.pdf

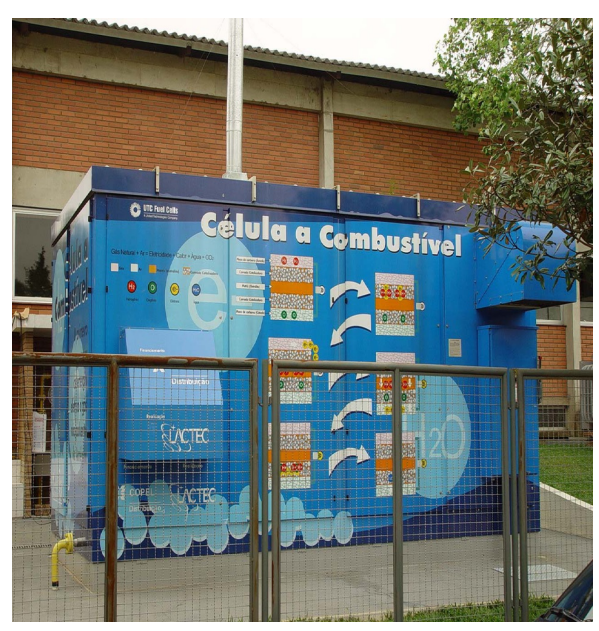

Figura 22: Célula da LACTEC

Fonte: PORTALH2, 2012. http://www.portalh2.com.br/prtlh2/images/artigos/a39.pdf 
Um ônibus movido a hidrogênio começou a rodar no mês de junho de 2009 em uma linha convencional urbana entre os bairros do Jabaquara, na zona Sul de São Paulo, e São Mateus, na zona Leste, passando pelos municípios de São Bernardo do Campo, Diadema, Santo André e Mauá, dentro da Região Metropolitana de São Paulo (REVISTA FAPESP, 2009). A ilustração 23 mostra o ônibus.

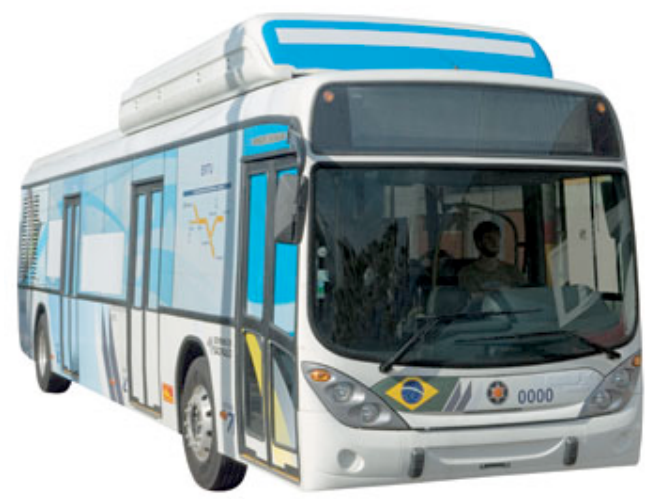

Figura 23: Ônibus à hidrogênio.

Fonte: Revista FAPESP, 2010. Disponível em $<$ http://www.revistapesquisa.fapesp.br/?art=3882\&bd=1\&pg=1\&lg>

O ônibus foi montado no Brasil com financiamento do Global Environment Facility (GEF), ou Fundo Global para o Meio Ambiente, uma agência ligada ao Banco Mundial, que financia iniciativas de desenvolvimento sustentável em vários países. O objetivo aqui é incorporar, integrar e desenvolver tecnologia de uso do hidrogênio como combustível e preparar as empresas para esse futuro mercado (REVISTA FAPESP, 2009).

$\mathrm{Na}$ Europa, desde 2004, o projeto Clean Urban Transport for Europe (CUTE), ou Transporte Urbano Limpo para a Europa, financiado pela União Europeia, permitiu que 38 ônibus Citaro movidos a hidrogênio circulassem por nove cidades como Londres, Madri, Barcelona, Amsterdã, Hamburgo, Stuttgart, Luxemburgo, Porto e Estocolmo. Entre as empresas nacionais investidoras no projeto estão a Petrobrás e a Eletropaulo. As duas estão envolvidas na unidade de produção do hidrogênio. O abastecimento do ônibus será feito na garagem da EMTU em São 
Bernardo do Campo, Essa unidade de produção e abastecimento é oriunda da empresa canadense Hydrogenics, especializada na produção de hidrogênio por eletrólise.

De acordo com o PROCAC, 2005 os projetos mais significativos de CaCs no Brasil são:

1. Programa Brasileiro de Células a Combustível (PROCaC) - Ministério da Ciência e Tecnologia (MCT) (Fundos Setoriais - R\$ 7 milhões em 2005).

a. Projeto de Formação das Redes Cooperativas;

b. Projeto Reformador de Etanol desenvolvido pela - INT / IPEN / CEPEL / COPPE;

c. Projeto de apoio à infraestrutura de laboratórios;

d. Formação de Recursos Humanos (Bolsas de Mestrado e Doutorado);

2. Centro de Pesquisa de Energia Elétrica (CEPEL) / Companhia hidroelétrica do São Francisco (CHESF) - Célula a combustível de 5kW-PEM fabricada pela empresa nacional ElectroCell, com reformador de gás natural (USA);

3. AES.Eletropaulo - Célula a combustível de $50 \mathrm{~kW}$ tipo PEM fabricada pela ElectroCell.

4. Instituto de Tecnologia para o Desenvolvimento (LACTEC) e Companhia Paranaense de Energia (COPEL) - 3 Unidades de célula a combustível tipo PAFC de 200 kWcada fabricada pela empresa norte americana UTC, alimentadas com gás natural.

5. Centro de Pesquisas e Desenvolvimento Leopoldo Américo Miguez de Mello (CENPES) Universidade Federal do Rio de Janeiro (Petrobrás) - 1 Unidade de célula a combustível tipo PAFC de 200kW fabricada pela empresa UTC, alimentada com gás natural.

6. Companhia Energética de Minas Gerais (CEMIG) / CLAMPLER, empresa mineira privada de equipamentos de proteção contra sobretensões elétricas transitórias / UNITECH empresa paulista privada de CaCs / USP - São Carlos - protótipos de células tipo PEM.

7. CEMIG/UNICAMP - Produção de hidrogênio por reforma de etanol e por eletrólise da água (Laboratório Na Usina Térmica de Igarapé).

8. CENPES (Petrobrás) - Célula a combustível de 5kW-PEM fabricada pela empresa UNITECH. 
9. UNICAMP/ Centro Nacional de Referência em Energia do Hidrogênio (CENEH) /MME Produção de hidrogênio por reforma de etanol e por eletrólise; e projeto VEGA de carro de passeio (híbrido - bateria e $\mathrm{CaC}$ ).

10. MME/EMTU/PNUD/GEF- Projeto de ônibus urbano na Cidade de São Paulo - 8 ônibus células a combustível fabricadas pela empresa Ballard -hidrogênio produzido por eletrólise.

11. Instituto Alberto Luiz Coimbra de Pôs graduação e Pesquisa de Engenharia (COPPEUFRJ) / LACTEC/ Petrobras / ELEBRA empresa paulista de informática - Projeto de um protótipo de ônibus urbano -hidrogênio produzido por reforma de gás natural.

12. Fundos Setoriais e Órgãos de Fomento:

A. Fundo Setorial de Petróleo e Gás Natural (CTPetro) - parceria entre Empresas e Universidades, Instituições de Ensino Superior ou Centros de Pesquisa do país, financiadas pela Financiadora de Estudos e Projetos (FINEP) e Conselho Nacional de Desenvolvimento Científico e Tecnológico (CNPq.);

B. Fundo Setorial de Energia (CTEnerg) - FINEP e CNPq;

C. CT-Verde-Amarelo - Programa de Estímulo à Interação Universidade-Empresa para Apoio à Inovação;

D. CNPq;

E. Fundação de Amparo à Pesquisa (FAPESP); etc.

\section{As políticas internacionais e nacionais em relação às células a combustível e o bidrogênio}

Apesar de se conhecer desde o sec. XVIII a capacidade energética do hidrogênio, este não foi muito explorado até o sec. XX. Somente em 1920 o uso energético do hidrogênio começou a ser explorado, primeiramente a aviação e depois em outros veículos (RIFKIN, 2003). Mesmo assim, seu uso energético foi muito restrito e em grande parte apenas experimental, 
ficando um pouco abandonado após o desastre com o Zeppelin Hindenburg em 1937 nos EUA, devido a ser altamente inflamável.

Foi somente na década de 1970, com a crise do petróleo, que o hidrogênio voltou a ser cogitado por cientistas e engenheiros como forma de energia. Em 1973 ocorreu a primeira Conferência Internacional sobre o Hidrogênio, em Miami, e resultou na criação da International Association for Hydrogen Energy e do periódico International Journal of Hydrogen Energy (RIFKIN, 2003).

Nos anos seguintes, tanto os EUA quanto a Europa começaram a investir alguns milhões de dólares em pesquisas sobre o hidrogênio. Porém, esses recursos foram sendo reduzidos conforme o mercado do petróleo foi se reestabilizando na década de 80 (RIFKIN, 2003).

Apenas no início da década de 90 o interesse pelo hidrogênio voltou a aumentar após as publicações sobre o aquecimento global devido à hipótese da emissão principalmente de CO2 através do uso dos combustíveis fósseis (RIFKIN, 2003). A partir de então, o uso do hidrogênio como vetor energético passou a ser de grande interesse para os países desenvolvidos e preocupados com o aquecimento global e grandes quantidades de recursos passaram a ser destinados à sua pesquisa e vários projetos tecnológicos e planificações começaram a ser implementados.

Em 1992, o Instituto Franholer de Sistemas de Energia Solar, na Alemanha, criou a primeira residência solar, empregando o hidrogênio para armazenar energia durante longos prazos. No ano seguinte, o Japão destinou dois bilhões de dólares a um plano de 30 anos para promover a energia do hidrogênio pelo mundo. Em 1994, os primeiros ônibus abastecidos com hidrogênio ganharam as ruas em Geel, na Bélgica. O Departamento de Trânsito de Chicago começou a testar seus próprios ônibus a hidrogênio um ano depois. O Royal Dutch/Shell Group ensaiou os primeiros passos na era do hidrogênio em 1998, escalando uma "Equipe do Hidrogênio" para explorar possibilidades comerciais e um ano depois criou uma divisão do 
hidrogênio. (...) Em 1999 a Islândia anunciou um ambicioso e ousado plano de longo prazo para se tornar a primeira economia do hidrogênio do mundo (RIFKIN, 2003, p. 186-187).

A General Motors foi a primeira a utilizar a expressão "economia do hidrogênio", na década de 70, quando passaram a encarar o hidrogênio como o combustível do futuro. Em 2003, os países membros da IEA (Interntional Energy Agency) se juntaram para discutir a formação de um grupo internacional para programas de P\&D e políticas estratégicas em tecnologias do hidrogênio. No mesmo ano foi criado o IPHE (International Partnership for Hydrogen Economy). O IPHE consisti numa parceria internacional, formada por dezessete países, incluindo o Brasil, proposta pelos EUA para estimular políticas e pesquisas públicas e privadas para as tecnologias do hidrogênio e a economia do hidrogênio, assim como regulamentos.

A IPHE é um mecanismo internacional criado para organizar e implementar a pesquisa, o desenvolvimento, a demonstração e a utilização comercial de atividades relacionadas ao hidrogênio e a célula a combustível. A IPHE é liderada pelos Estados Unidos e foi estabelecida em 2003 como uma instituição internacional para acelerar a transição para a Economia do Hidrogênio, bem como para estabelecer os critérios e procedimentos a serem cumpridos pelos países membros (ROHRICH, 2008).

Uma das principais razões dos países envolvidos na implantação da economia do hidrogênio é o fato do hidrogênio ser um vetor energético limpo e que pode ser obtido de uma infinidade de fontes diferentes, fósseis ou renováveis. É interessante notar que é a primeira vez que um critério não econômico, no caso, o ambiental, conta para uma política energética internacional (PEREIRA, 2003).

Em 2003 o IPHE definiu as áreas prioritárias para a transição para a Economia do Hidrogênio, que são: P\&D em células a combustível; produção do hidrogênio; armazenagem do hidrogênio; regulamentos e padrões para as células a combustível e o hidrogênio; e questões socioeconômicas para o hidrogênio. Os documentos oficiais referentes a cada área foram denominados Scoping Papers, e o Brasil participa de todos (ROHRICH, 2008). 
No Brasil, o maior financiador em projetos de pesquisa em Células a Combustível e Hidrogênio até o momento é a FINEP (Financiadora de Estudos e Projetos), que, até 2007, financiava 21 projetos, no valor aprovado de $\mathrm{R} \$ 40$ milhões. Em segundo lugar vem a FAPESP, com 199 projetos e $\mathrm{R} \$ 26$ milhões. No total foram contados 287 projetos até 2007 e um valor aprovado de quase $\mathrm{R} \$ 98$ milhões (MATOS, 2009). O quadro 13 mostra o resumo dos financiamentos em pesquisas de $\mathrm{CaC}$ e $\mathrm{H} 2$.

\begin{tabular}{|c|c|c|}
\hline Fonte de fomento & $\mathbf{N}^{\circ}$ de projetos & Investimentos (reais) \\
\hline FINEP & 21 & $40.630 .000,88$ \\
\hline FAPESP & 199 & $26.985 .285,00$ \\
\hline P\&D ANEEL & 19 & $21.318 .538,00$ \\
\hline CNPQ & 43 & $8.930 .522,00$ \\
\hline FAPERGS & 3 & $38.100,00$ \\
\hline FAPESC & 1 & $17.870,00$ \\
\hline FAPEMIG & 0 & 0 \\
\hline TOTAL & 287 & $97.976 .580,70$ \\
\hline
\end{tabular}

Quadro 13 Financiamentos em pesquisas em CaC e Hidrogênio.

Fonte: MATOS, 2009, p. 43.

Em 2002, o MCT criou o Programa Brasileiro de Sistemas de Células a Combustível (PROCaC) com o objetivo de organizar uma rede de pesquisas e promover ações integradas e cooperadas, que viabilizem o desenvolvimento nacional da tecnologia de sistemas célula a combustível (MCT, Portaria $n^{\circ} 731$, de 14.11.2002).

Em 2005 o programa passou a se denominar Programa de Ciência, Tecnologia e Inovação para a Economia do Hidrogênio (ProH2) e estruturou cinco redes de pesquisa. Ao mesmo tempo, em 2004 o Ministério de Minas e Energia (MME) criou o Roteiro para a Estruturação da Economia do Hidrogênio no Brasil. Baseado no PROCaC e em sintonia com o MCT, o MME criou o programa para estimular pesquisas e políticas energéticas baseadas no hidrogênio. O objetivo do programa é que até o ano de 2025 o hidrogênio seja introduzido na matriz energética brasileira de maneira expressiva, como foi feito com o álcool.

O governo FHC apoiou as pesquisas em células a combustível em consonância com o restante do mundo na época, principalmente após George W. Bush assumir a presidência dos 
EUA em 2001 e direcionar seu apoio às $\mathrm{CaC}$ nos automóveis elétricos, ao invés das tradicionais baterias. O programa brasileiro para a pesquisa em células a combustível (ProCac) só saiu em 2002, no final do mandato de FHC.

O primeiro governo Lula ainda apoiou as pesquisas na área, fase em que foi liberada a maior quantidade de verba. Segundo os secretários do CENEH (Centro Nacional de Referência em Energia do Hidrogênio) da UNICAMP, enquanto os EUA pretendiam utilizar fontes fósseis combinadas com o sequestro de carbono para produzir hidrogênio, o Roteiro para a Estruturação da Economia do Hidrogênio no Brasil, do MME (que faz parte dos programas do IPHE), previa utilizar as células eletrolíticas e o hidrogênio para viabilizar fontes de energia renováveis como a eólica e solar.

Porém, as políticas voltadas para o hidrogênio e as $\mathrm{CaC}$ sofreram uma grande interrupção depois da posse de Obama, que deu novamente prioridade ao carro elétrico, já que o presidente Obama não é ligado à indústria do petróleo como Bush era. Consequentemente, as políticas no mundo todo, incluindo o Brasil, sofreram também com isso um grande desestímulo.

Em maio de 2009, quando o Centro de Gestão e Estudos Estratégicos (CGEE) publicava um completo estudo sobre a Economia do Hidrogênio no Brasil, o presidente dos Estados Unidos, Barack Obama, anunciava um corte anual de US\$100 milhões em investimentos no desenvolvimento de carros movidos a hidrogênio. A decisão do governo norte-americano, na avaliação do assessor do CGEE, Demétrio Filho, irá gerar impactos nas pesquisas do setor no mundo todo. "É difícil avaliar em um curto intervalo de tempo quais serão os impactos. A maior parte da pesquisa que está sendo realizada hoje é fruto de projetos que já estavam em andamento. Precisamos observar o que vai acontecer de agora em diante (CGEE, 2009).

Os secretários do CENEH também explicam o que aconteceu de acordo com uma entrevista realizada por Lorenzzi, 2012:

O sistema que o Bush tinha proposto que era o uso do hidrogênio veicular, com células a combustível, foi adiado no governo Obama, que preferiu apostar nas baterias. O que também não deu certo até agora. Os carros elétricos continuam com os mesmo problemas de sempre, que é baixa autonomia e tempo de carga das baterias muito elevado. $\mathrm{E}$ as baterias também não caíram de preço, exceto aquelas que os chineses estão fazendo. Então, a nossa expectativa aqui é que mais alguns anos eles vão ver que isso não deu certo e vão voltar para o carro a hidrogênio. E vai voltar. Só que parece que mais uns 8,10 anos vão ficar isso aí. As 
grandes montadoras só correram atrás do carro a hidrogênio depois que o Bush falou que queria o carro a hidrogênio (secretário CENEH).

Essa controvérsia é antiga e já foi explorada por Callon (1987). Em seu estudo, o autor fala sobre o desenvolvimento do veículo elétrico na França na década de 70 e esse dilema já aparece. A EDF (Eletricité de France) organiza um projeto para o desenvolvimento de um carro elétrico que utilizasse baterias recarregáveis ou células a combustíveis.

Na época, a tecnologia escolhida foram as células a combustível, devido à vantagem do tempo de recarga ser muito menor (como o de abastecer um carro convencional). Porém, naquele momento as células a combustíveis ainda não eram eficientes o suficientes, devido aos catalisadores da época, e as baterias também se mostravam caras, o que levou ao abandono do projeto.

Entretanto, os secretários do CENEH enfatizam que mesmo assim, o hidrogênio e suas tecnologias não foram abandonados. Os carros a bateria tem problemas grandes, como o peso dessas, o preço e o elevado tempo de recarga. Essas dificuldades são problemas técnicos que segundo eles dificilmente serão superados.

Você percebe que eles não largaram totalmente. Você percebe que eles continuam a trabalhar nisso. Claro, menos. Diminuíram os investimentos. Mas eles estão vendo que esse negócio de bateria é furada. Porque quem é do ramo, quem entende, sabe que a possibilidade das baterias atenderem o que o governo americano quer é muito baixa (Ennio Peres da Silva, secretário do CENEH).

Segundo os secretários do CENEH, enquanto a FINEP gerenciava e financiava os projetos, as pesquisas e desenvolvimento progrediam, pois tinham autonomia e apoio. No momento que isso passou para o MCT e se organizaram as redes formais através do PROCaC, as coisas começaram a deixar de funcionar adequadamente.

Enquanto a FINEP financiava e coordenava os projetos, tudo estava andando muito bem, tínhamos até projetos de sistemas de $\mathrm{CaC}$ que superavam projetos no exterior (como o Vega 1). Porém, quando o MCT lançou o programa (PROCaC) e assumiu a coordenação dos projetos e estruturou as redes, tudo parou de andar. Ninguém mais recebia as verbas nos prazos combinados, o que desestimulava os pesquisadores $\mathrm{e}$ 


\section{em residências}

criou atrasos generalizados, já que um dependia do outro nesta rede. Não demorou muito até tudo parar (secretário do CENEH).

As instituições de pesquisas envolvidas na rede construída não recebiam os recursos previstos e por isso não era possível cumprir os prazos. A cadeia de desenvolvimento projetada entre as diversas instituições no projeto não funcionava, pois uma dependia da outra e não se cumpriam os prazos. Logo pararam totalmente de receber recursos e tudo se estacionou. Quando o projeto e a rede foram rearranjados no $\mathrm{PROH} 2$, foi liberado apenas mais algum montante, as coisas andaram um tempo e logo pararam novamente, devido aos mesmos motivos.

Pode parecer que o programa do MCT e o do MME buscavam as mesmas coisas, ou seja, estimular o desenvolvimento das tecnologias do hidrogênio no mercado brasileiro. E, na prática, era mais ou menos isso. Segundo o secretário entrevistado do CENEH, o MCT lançou o PROCaC, mas efetivamente não estava sendo feito quase nada. Porém, o MME, na época chefiado por Dilma Roussef, queria que isso fosse pra frente e então tomou isso para si.

Então a Dilma pegou o ministério, essa parte do hidrogênio, e colocou o MME num acordo internacional sobre hidrogênio. Ela foi aos EUA e assinou um convenio de cooperação bilateral em julho de 2003. Em dezembro ela voltou lá para assinar a participação do Brasil no IPHE. E ai obviamente tinha que fazer as coisas. O IPHE propôs que cada membro propusesse o seu roteiro. E ela fez o roteiro. Ai ela pegou várias pessoas que também trabalhavam nesse negócio do hidrogênio no MCT e levou pra lá pra fazer o roteiro. Então, ela começou a trabalhar essa questão do roteiro e dentro do roteiro foi colocado todas as linhas que o Brasil devia seguir em termos de desenvolvimento dessa tecnologia. Ou seja, ela estava fazendo o que o MCT não estava fazendo. Tudo o que acontecia com o hidrogênio acontecia mais no MME que no MCT (secretário do CENEH).

Porém, assim que Dilma Roussef saiu do MME para assumir a Casa Civil em junho de 2005, as coisas relacionadas ao hidrogênio pararam de andar no MME. Segundo secretário do

\section{CENEH:}

Quando ela saiu, ficou a Maria da Graça Foster, cuidando do hidrogênio no MME, mas a Maria da Graça ficou mais uns 6 meses. Ela terminou o roteiro, teve uma reunião do IPHE no Brasil onde foi apresentado esse roteiro. E logo em seguida a Maria da Graça saiu. Ai acabou. Do jeito que ela largou ficou até hoje. Quando ela saiu, o negócio 
ficou exatamente no mesmo ponto. A única coisa que aconteceu a mais foi que a gestão seguinte contratou uma atualização do roteiro, contratou uma pessoa pra fazer isso, e não pagaram (secretário do CENEH).

Esses problemas indicados pelo CENEH na rede estruturada pelo MCT lembram os processos identificados por Callon (1986). Num primeiro momento, vários atores se mobilizaram junto à FINEP e o MCT para tentar garantir suas participações e partes do orçamento no programa que seria inaugurado (processo de problematização). Os desacordos que os secretários do CENEH apontam indicam claramente os processos de atração e envolvimento. Porém, não vemos um acordo sólido entre os membros, o que apontaria o desfecho desses processos, nem o início do processo de mobilização, quando os atores já se veriam como uma coletividade organizada e buscariam uma representação forte e confiável.

Isso nos leva a outro problema muito maior, no caso, relacionado à estrutura da política nacional. No Brasil, as políticas são coisas pessoalizadas, ou seja, dificilmente encontramos políticas de Estado, mas sim de governos, ligadas às pessoas que a iniciaram, e que geralmente se encerram também com elas (ALMEIDA, 2009). Os ministérios, muitos deles considerados de segunda importância, também funcionam como instrumentos de poder para se firmar alianças e dificilmente seus projetos são levados adiantes quando há trocas de responsáveis.

Nós temos problemas técnicos, óbvio, porque é uma tecnologia difícil de fazer. Temos dificuldades financeiras porque você não consegue administrar o dinheiro dessa forma. E não há um plano. Nós já fizemos um plano várias vezes. Vamos comprar uma célula de cada, colocar tudo junto pra comparar, entender o estado da arte. Mas não consegue dinheiro pra isso. Então as coisas não andam (secretário CENEH).

Essa falta de compromisso com os programas governamentais é parte do problema relacionado ao financiamento do desenvolvimento e pesquisas de $\mathrm{CaC}$ no Brasil. Porém, não é só com programas governamentais que se faz pesquisa e isso faz parte de um problema maior: uma desarticulação entre os setores de pesquisa, governamental e mercado. No Brasil, atualmente, as pesquisas e desenvolvimento em $\mathrm{CaC}$ se concentram principalmente em três áreas: a) pesquisas em células a combustível de membrana condutora de prótons (PEMFC); b) 
células a combustível de óxido sólido (SOFC); c) na reforma do etanol para a produção de hidrogênio e catalisadores (CGEE, 2010). Até 2007, cerca de 290 projetos já foram ou estão sendo executados na área de pesquisa em células a combustível e hidrogênio com financiamento público, num total de cerca de $\mathrm{R} \$ 133$ milhões (MATOS, 2009).

Há também alguns poucos projetos de demonstração em andamento, como alguns ônibus movidos a hidrogênio rodando na cidade de São Paulo e um projeto da UFRJ de colocar alguns ônibus movidos a hidrogênio em 2014 para a copa do mundo no Brasil.

Através da revisão de documentos importantes (CGEE, 2010) e de entrevistas com o pessoal do CENEH e empresários do setor, foi possível constatar os principais entraves tecnológicos e sociais nas pesquisas em células a combustível e hidrogênio. No que se refere aos principais gargalos tecnológicos, os pesquisadores e empresários entrevistados apontam, na seguinte ordem:

a) A questão do armazenamento do hidrogênio. Apesar de já ser amplamente desenvolvido no resto do mundo cilindros que suportam altas pressões (350 bar ou maior), no Brasil ainda não são desenvolvidos e comercializados cilindros de alta pressão e sua importação é dificultada pela burocracia.

b) Os altos custos desta tecnologia, que não são subsidiados nem incentivados tributariamente, como são no restante do mundo.

c) O desenvolvimento e aquisição de equipamentos.

d) A questão da distribuição do hidrogênio, onde ainda não há uma infraestrutura para isso.

e) A eficiência das células a combustível. Apesar de já se encontrar na casa dos $50 \%$ é um dos maiores desafios a serem superados no Brasil e no mundo para compensar os seus custos. 
Não podemos esquecer que estes gargalos tecnológicos estão ligados aos problemas de infraestrutura, sendo a maior parte na verdade reflexos das limitações da infraestrutura, como financiamento, formação de RH, normatização, etc.

Segundo os secretários do $\mathrm{CENEH}$, o Brasil ainda está muito atrasado em relação a outros países, até mesmo de países emergentes como a Rússia, China e Índia. Nesses países, o setor governamental e o empresarial parecem estar mais bem articulados do que no Brasil, pois, ao contrário desses países, onde há incentivos fiscais e até mesmo subsídios nessa área, o Brasil tributa normalmente essas pesquisas, onde cerca de $30 \%$ dos custos são devidos a impostos. Os pesquisadores e empresários entrevistados apontam como o maior problema para a pesquisa e desenvolvimento das células a combustível no Brasil as questões de infraestrutura.

Segundo eles, a falta de financiamento e a formação de $\mathrm{RH}$ são os maiores problemas para o setor. Apesar do montante já aplicado no Brasil, isso representa apenas cerca de $30 \%$ do que Rússia, China ou Índia já investiram cada um ou cerca de $4 \%$ do que EUA, Japão ou União Europeia já investiram individualmente (CGEE, 2010).

Atualmente há pouquíssimas normas referentes ao uso e funcionamento das células a combustível. Enquanto outros países já estão extremamente avançados nesse quesito (mesmo a Índia), no Brasil há falta de pessoal contratado para esse serviço, e ainda nem se traduziu totalmente as normas dos outros países para se usar como referência (CGEE, 2010). Esse problema atrapalha muito o desenvolvimento de células a combustível pelas empresas brasileiras, já que enquanto não houver padrões definidos, não há garantia de uso e sucesso no futuro. Isso também é um indício de desarticulação entre o setor governamental e o de P\&D.

Há a necessidade do apoio aos programas de Tecnologia Industrial Básica (TIB), uma vez que o Brasil já está atingindo um maior patamar na área de hidrogênio, com a necessidade de maior desenvolvimento da pesquisa aplicada e das etapas seguintes, de demonstração e comercialização de bens ligados ao hidrogênio energético. Isso ocorreria com um suporte maior à cadeia "metrologia, normalização, regulamentação técnica e avaliação da conformidade", estando incluído também o aumento da confiabilidade metrológica nas medições em sistemas de células a combustível (CGEE, 2010, p. 17). 
Essa desarticulação entre os atores não se restringe apenas a área das células a combustível. Com poucas exceções, não há estímulos financeiros ou tributários para P\&D de nenhuma tecnologia considerada limpa e renovável. Faltam políticas públicas nesse setor da economia e sobram problemas burocráticos.

A formação de recursos humanos também é alvo de críticas dos empresários da área, pois, a maior parte das pesquisas é feitas por alunos de pós-graduação, que abandonam suas pesquisas ao fim de suas bolsas e não encontram posteriormente oportunidades nas empresas para atuar nessa área. Não há no caso uma política governamental que incentive a formação e atuação na área de células a combustível e outras tecnologias consideradas renováveis, o que prejudica no Brasil o desenvolvimento desse setor.

Segundo os pesquisadores entrevistados, parcerias entre as universidades e as empresas privadas também são pouquíssimas até o momento. Como não há um mercado ainda para as células de combustível e não há nenhum incentivo fiscal para o seu desenvolvimento, as empresas geralmente não se arriscam nesse tipo de inovação.

Algumas das poucas parcerias que se concretizaram até o momento são entre as universidades e algumas distribuidoras de energia, mas, somente devido à lei de P\&D da ANEEL (resolução n²42 da ANEEL, de 1998) que obriga as empresas do setor elétrico a aplicarem pelo menos $1 \%$ de seus lucros em P\&D para a eficiência e conservação energética, e são pesquisas muito específicas para as empresas, que só ajudam a universidade com a verba que transferem.

Uma solução sugerida pelos pesquisadores para esse problema e que também articularia melhor o setor empresarial e o de pesquisa seria a exigência para a sua aprovação de parceria com empresas em projetos de demonstração, além da ampliação desses últimos.

A realização de projetos de demonstração tem como intuito a disseminação de informações relacionadas às tecnologias do hidrogênio ao público alvo leigo. A integração de empresas às instituições de pesquisa no desenvolvimento dos projetos de demonstração deve ser um requisito para sua aprovação. Os recursos necessários à realização dos projetos podem ser oriundos dos Fundos Setoriais CT-Energ e CT-Petro, e projetos de P\&D ANEEL (CGEE, 2010, p.19) 
Segundo os empresários do setor de células a combustível, o financiamento de projetos para empresas do ramo, é extremamente difícil. Não há nenhuma linha de crédito especial para esse tipo de pesquisa, e o BNDES cobra muitas coisas impossíveis de serem comprovadas por uma empresa que está começando nesse mercado ainda quase inexistente, como comprovação de grandes lucros nos últimos 5 anos. Isso inviabiliza qualquer chance de crédito especial e acaba sobrando apenas o capital de risco, com altos juros.

Há problemas também nas leis, que atrasam o desenvolvimento das pesquisas e evidenciam uma desarticulação entre o setor governamental e o setor de pesquisa e inovação. Os grandes projetos, financiados pela FINEP, sofrem muitos problemas burocráticos e de liberação de verbas. Um ponto muito criticado pelos pesquisadores entrevistados é a lei 8.666 de 1993. Segundo ela, qualquer instituição pública deve convocar licitação para a compra de equipamentos e serviços. Apesar do artigo 24 desta mesma lei prever que é dispensável a convocação de licitação no caso de pesquisas, desenvolvimento e inovação e em casos que o mercado nacional não possua equipamentos com a mesma qualidade necessária ou preço semelhante, as fundações que recebem a verba da FINEP e repassam para os projetos de pesquisa temem algum problema com a interpretação do caso e da lei (bastante confusa) por parte do tribunal de contas e acabam exigindo que os projetos de pesquisa convoquem licitações, mesmo teoricamente sendo dispensável.

Segundo os diretores do CENEH, o novo modelo de financiamento, que passa agora pelas fundações, juntamente com a lei 8.666 atrapalha muito o desenvolvimento das pesquisas. Além da grande demora para a liberação dos recursos, o laboratório tem prestar contas e pagar impostos sobre todos os equipamentos adquiridos

Poucas empresas no Brasil têm condições de oferecer os equipamentos necessários para a pesquisa em células a combustível e produção de hidrogênio, porém, muitas querem ganhar as licitações. O que os pesquisadores entrevistados dizem que acontece é que muitas 
vezes algumas empresas reduzem o valor só para ganhar a licitação e depois, só no fim do contrato, declaram que não tem condições de produzir e entregar o equipamento.

É necessário, então, convocar outra licitação... Esse processo atrasa muito as pesquisas e, segundo os pesquisadores, muitas vezes as inviabilizam. Há nesse caso uma evidente desarticulação entre critérios legislativos, econômicos e científicos. É necessário uma adequação da lei para que haja a harmonia necessária para o desenvolvimento tecnológico dessa e de outras tecnologias que dependem parcialmente de equipamentos importados.

Todos esses problemas nos revelam uma imensa desarticulação entre o setor governamental e o de pesquisas. Os atores relacionados às pesquisas não têm o apoio necessários dos atores políticos. Ao mesmo tempo, os atores relacionados a essa indústria do hidrogênio e de CaC são muito poucos, já que não encontram estímulos e um mercado adequado. As leis não se encaixam e os modelos de P\&D propostos pelos ministérios não funcionam adequadamente devido a essa desarticulação e também a consequente fraqueza da coordenação do projeto.

Toda construção de um fato científico ou desenvolvimento de alguma tecnologia, necessariamente se dá por meio de redes heterogêneas para se concretizar. É impossível fazêlo se não através de uma rede que envolve cientistas, programas políticos, mercado, sociedade civil, etc. Nenhum laboratório moderno ou empresa dedicada ao desenvolvimento de novos produtos pode atuar sozinhos. Essa rede que se forma naturalmente pode ser chamada de rede informal se comparada às redes formais estruturadas em um projeto governamental. São essas redes formais que os secretários do CENEH criticam.

Existe um problema muito maior na política nacional, onde diversos ministérios são criados, porém, recebem muito mais ênfase na escolha de seus membros, muitas vezes aliados ao invés de técnicos ou especialistas no assunto, do que importância, recursos e efetivamente poder para atuar na área em que foram propostos na sua criação. 


\section{em residências}

Muitos projetos desses ministérios são praticamente abandonados de um governo para outro, ou mesmo dentro de um mesmo governo, devido á troca de cargos. Há também muitos projetos que já nascem condenados devido à força e importância atribuídos a alguns ministérios, considerados de segunda importância.

Segundo os diretores do CENEH, é impossível para o Brasil atualmente competir em tecnologias de ponta, como a construção de células a combustível eficientes para utilização em veículos, com empresas estrangeiras, como as dos EUA, que investiram bilhões de dólares em pesquisas, enquanto no Brasil foram investidos apenas alguns milhões, ou seja, cerca de mil vezes mais.

A sugestão do CENEH é investir em P\&D de tecnologias que não são exploradas lá fora (como muitas outras vezes é feito em outras áreas), como em sistemas de células a combustível.

Sistemas nada mais são que os arranjos necessários para que, por exemplo, uma célula a combustível movimente um carro, alimente um dispositivo eletrônico, como computadores portáteis, etc. A célula a combustível pode ser importada (já que é muito mais barata e eficiente que uma nacional), porém todo o restante pode ser nacional.

Um nicho tecnológico em que sistemas de células a combustível deve rapidamente se consolidar é o que hoje é dominado pelas baterias, como notebooks, celulares e outros equipamentos eletrônicos. Uma pequena célula a combustível carregada com uma pequena quantidade de hidrogênio comprimido é muito mais leve do que uma bateria de lítio. Ainda por cima, podem ser muito mais duradouras (em duração da carga e vida útil) que as tradicionais baterias, e também podem ser facilmente carregadas. As baterias em geral devem ser rapidamente substituídas por células a combustível, provavelmente antes de todas as outros usos energéticos do hidrogênio se estabelecer.

Outro ponto importante a exaltar é o avanço no desenvolvimento da produção de hidrogênio no Brasil, necessário para a consolidação do uso energético do hidrogênio e das 
tecnologias relacionadas. Do mesmo jeito que no caso anterior, a célula eletrolítica ou fotovoltaica pode ser importada, porém todo o restante do sistema reformador pode ser nacional. É necessário investir nesses sistemas para que possa se produzir a quantidade de hidrogênio necessária e a um baixo custo.

Para os secretários do CENEH, o mercado de hidrogênio, assim como os veículos movidos a hidrogênio com $\mathrm{CaC}$, devem se tornar uma realidade no Brasil, assim como no resto do mundo. O Brasil deve acompanhar os outros países nesse sentido, pois assim que começarem a chegar os carros movidos a hidrogênio, que devem chegar, devido à evolução que têm tido em sua eficiência (muito mais eficiente que um motor a combustão) e custo, o mercado rapidamente se movimenta e implementa todo o resto necessário - infra-estrutura de produção, armazenamento, transporte, abastecimento - para suportar o novo paradigma.

Neste ponto uma comparação faz-se útil. Imagine os tempos iniciais da invenção do automóvel. Não havia infraestrutura para a rolagem dos automóveis, que tinha, por sua vez, preços proibitivos. A gasolina não era nem abundante nem barata e tampouco se encontrava em cada esquina. Pois bem, aproximadamente cem anos depois o automóvel tornou-se accessível, existem estradas para sua rolagem e pode-se abastecê-lo em qualquer lugar, ou seja, aprendemos a lidar com o combustível e, com a produção em massa e o mercado, os preços caíram (LINARDI, 2008).

Os secretários do CENEH utilizam o exemplo do Gás Natural. No início também se dizia que não havia infraestrutura, que não havia combustível, que não havia postos de abastecimento, etc, e que por isso não poderia dar certo. Porém, assim que chegaram e se converteram os primeiros automóveis a gás natural, rapidamente os postos se adequaram, empresas começaram a construir e fornecer os equipamentos, empresas passaram a se dedicar ao transporte do gás, que requeria equipamento especial, e o gás natural, que se era queimado nas plataformas da Petrobrás por não se ter o que fazer com ele, começou a ser aproveitado.

Segundo eles, com o hidrogênio deve acontecer a mesma coisa. Já existem equipamentos para se produzir hidrogênio purificado, são simples, e assim que começarem a aparecerem os veículos, deve surgir espontaneamente também toda a infraestrutura necessária. 
Ainda, muito antes dos veículos, segundo o CENEH deve se consolidar o uso da geração estacionária com hidrogênio. As tecnologias nessa área já estão muito mais desenvolvidas e são muito mais requeridas no momento. São necessárias em estações de geração de segurança em locais que não podem ficar sem energia, como hospitais, centros de telecomunicação, laboratórios, etc. Também em locais que não estão conectados ao sistema elétrico nacional, como comunidades isoladas. Nestes exemplos, os velhos geradores a dieses ou querosene devem ser substituídos por células a combustível movidas a hidrogênio, que são muito mais eficientes e silenciosas, além de darem muito menos problemas. Assim que começarem a ser utilizadas, sua produção em escala deve reduzir muito os seus custos, tornando mais viáveis que os velhos sistemas geradores. Inclusive, já são utilizados por algumas empresas.

\subsection{O SISGEOA SOLAR - ЋIDROGỂIO - CÉLULA A COMBUSGÍVEL}

Para gerar energia o sistema funciona a partir do momento em que há luz solar iniciando o processo de produção e estocagem de hidrogênio. Durante o dia o sistema pode obter energia elétrica dos painéis solares e da célula, e a noite ou em dias nublados, o sistema ativa a célula combustível.

O excedente de energia solar é utilizado para produzir hidrogênio e oxigênio através da eletrólise da água. O hidrogênio e o oxigênio podem ser armazenados em tanques onde estão prontos para serem utilizados na célula quando se necessita de energia elétrica.

A energia solar é utilizada para fazer a eletrolise da água através de um eletrolisador obtendo como resultado hidrogênio e oxigênio em estado gasoso. Esses gases são estocados e recombinados por intermédio de reações eletroquímicas dentro da célula combustível tendo como produto água pura e energia elétrica. 
O sistema ainda pode ser interconectado à rede de serviço público de abastecimento de energia, e quando houver hidrogênio sobrando e os dispositivos da casa estiverem em repouso a eletricidade adicional poderá ser injetada na rede. A figura 24 mostra o esquema de funcionamento do sistema, e a figura 25 ilustra o funcionamento do sistema em uma casa convencional conectada a rede de elétrica:

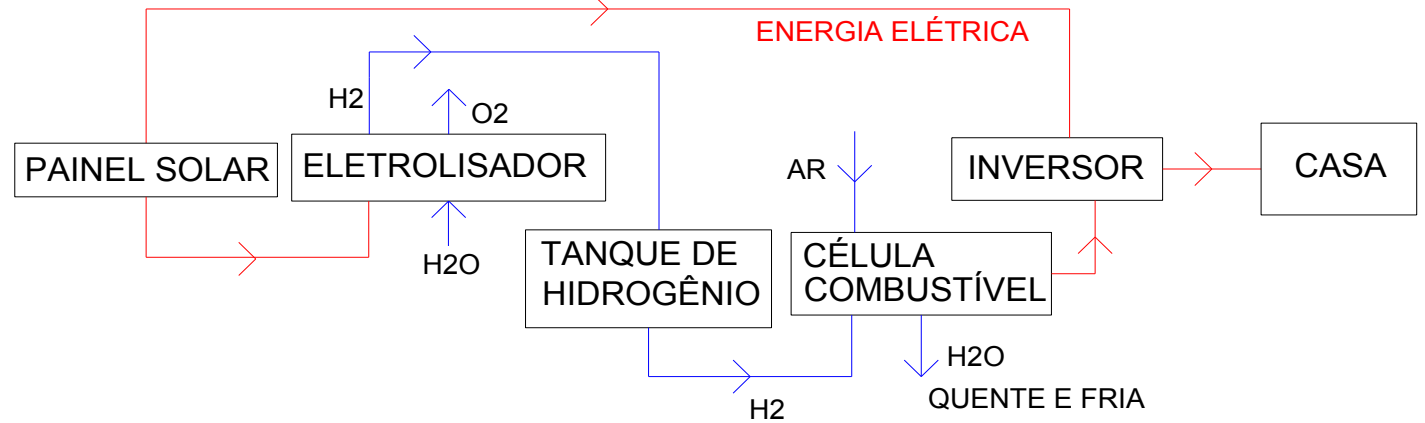

Figura 24. Esquema de funcionamento do sistema Solar-hidrogênio.

Fonte: Dados obtidos da empresa UNITECH Ltda.

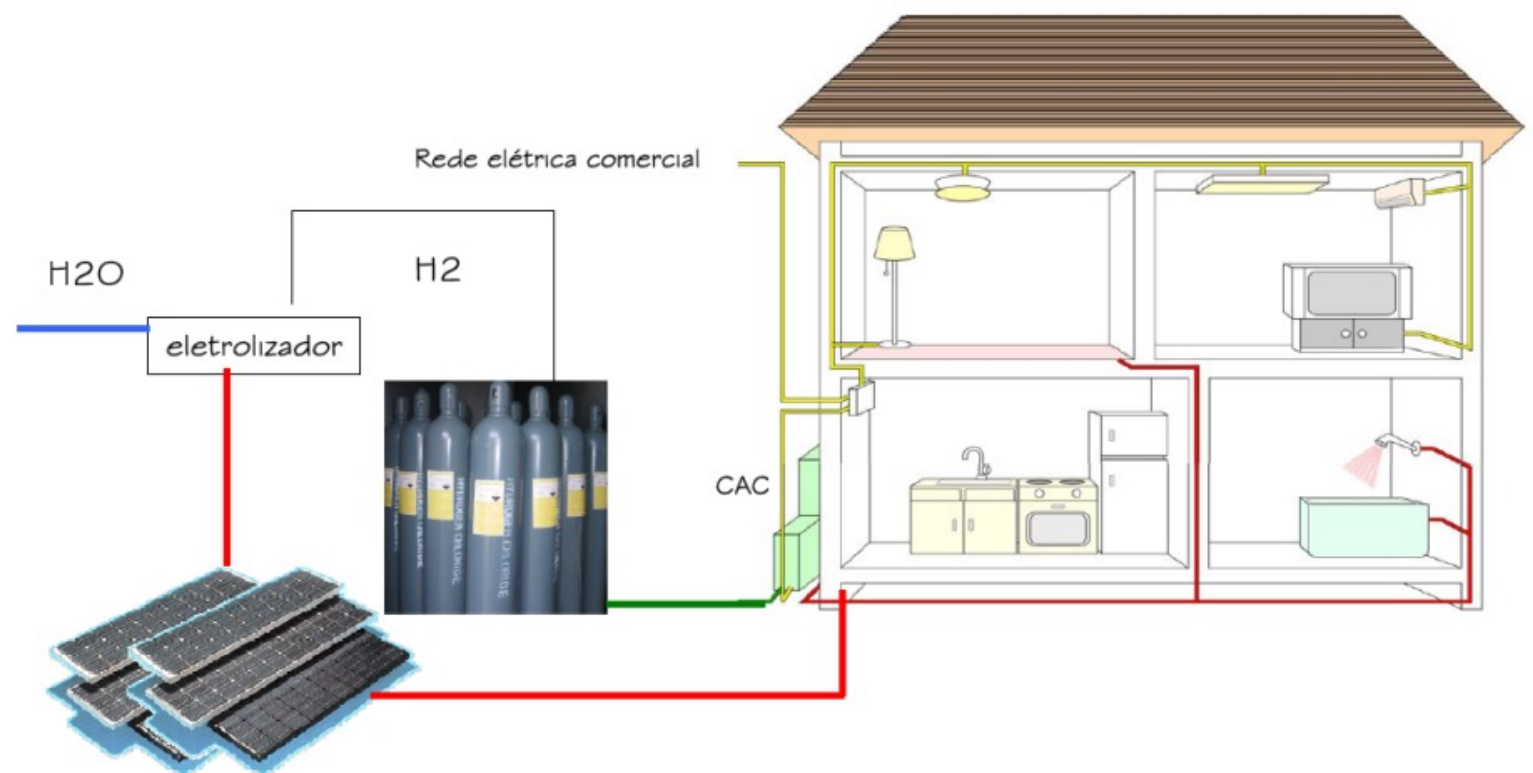

Figura 25: Funcionamento do sistema em uma casa conectada à rede elétrica convencional.

Fonte: Elaboração própria.

Quanto ao dimensionamento do sistema deve-se estabelecer através de uma relação da área do painél com a quantidade de hidrogênio requerido e a potência da CaC. Depende de uma 
série de fatores, como por exemplo, da eficiência e potência das células, a incidência solar, a curva demanda energética e a potencia do painel solar. Compilados esses dados, os números são colocados em um modelo matemático (desenvolvido pela empresa de células UNITECH, e adaptado (modificado) para o presente trabalho).

A eficiência do eletrolisador também contribui para análise em específico. Outro ponto é que a energia da célula fotovoltaica não é usada apenas para produzir hidrogênio, ela fornece energia direto para o edifício. Para gerar $1 \mathrm{~kW}$ de energia na célula combustível necessita-se de $1 \mathrm{M}^{3}$ de hidrogênio, de acordo com o modelo matemático e vários fabricantes.

Uma célula de $5 \mathrm{~kW}$, usada geralmente para estacionárias residenciais mede 1 metro e 30 centímetros $(\mathrm{cm})$ de comprimento por $84 \mathrm{~cm}$ de largura e 1,10 metro de altura. O coração do equipamento, que é a própria célula, mede $47 \mathrm{~cm}$ de comprimento por $30 \mathrm{~cm}$ de largura e $30 \mathrm{~cm}$ de altura.

\footnotetext{
"Uma área de 100 metros quadrados $\left(\mathrm{m}^{2}\right)$ produziria hidrogênio suficiente para uma casa porque é possível estocar hidrogênio em cilindros e usá-lo à noite ou quando não houver captação de energia solar suficiente, em dias nublados ou no inverno. Isso evitaria o custoso e difícil processo de armazenar energia elétrica obtida da energia solar ou eólica, tradicionalmente feito com uso de baterias." (FAPESP, 2004).
}

O custo do quilowatt hora ( $\mathrm{kWh}$ ) de energia elétrica produzida com o sistema energia solar, eletrólise e célula a combustível pode ficar em torno de $R \$ 0,41$. Esse sistema completo de geração de energia elétrica também está sendo desenvolvido pela empresa UNITECH (FAPESP, 2004).

"Na operação da célula, a opção mais barata é o gás natural, que custa, no mínimo, $R \$ 0,76$ o metro cúbico $(1 \mathrm{~m} 3)$, porção suficiente para produzir $4 \mathrm{~m} 3$ de hidrogênio e, consequentemente, $4 \mathrm{kWh}$ de energia elétrica. Dessa forma, o kWh da energia seria de R\$ 0,19." (FAPESP, 2004).

Porém nesse caso de alimentar a $\mathrm{CaC}$ com gás natural a ideia de geração distribuída seria descartada. Para a obtenção de hidrogênio é feita a eletrólise da água usando também a energia eólica, o conceito é mesmo com a energia solar. Pode-se armazenar o excesso de 
geração de energia eólica na forma de hidrogênio. Quando não se tem vento, utiliza-se o sistema de células a combustível para gerar energia elétrica a partir do hidrogênio. Já existem algumas comunidades no mundo que utilizam este conceito, porém para o presente trabalho os ventos não são significantes na região de estudo.

Já na utilização do gás natural como fonte primária de energia para fornecimento da célula é realizada a reforma do gás para obtenção de hidrogênio, e a utilização do etanol como combustível pode ser direto na alimentação da célula, no entanto ainda são tecnologias em fases primárias de desenvolvimento.

A casa desconectada da rede é independente, autônoma. A água quente pode ser adquirida pela energia solar térmica e pela eletricidade advinda da solar fotovoltaica e eólica, e ainda da eletricidade gerada pelo conjunto célula e hidrogênio. O armazenamento de energia é feito em forma de hidrogênio gasosa e quando a eletricidade solar fotovoltaica e/ou eólica não forem suficientes é acionada a geração de energia através das células a combustível a partir do hidrogênio estocado. As reservas de eletricidade podem servir também para abastecer um carro movido a hidrogênio futuramente.

Os principais objetivos de um sistema fotovoltaico com armazenamento em hidrogênio desenvolvidos atualmente são demonstrar a sua viabilidade técnica e, a partir dos resultados, desenvolver um método matemático global que envolva todos os fluxos de energia e considere todas as eficiências das transformações envolvidas e que possa servir para modelar e simular a operação de sistemas dessa natureza, para com isso determinar os custos desta tecnologia (FURLAN, 2008).

Para otimizar o desempenho do sistema é de fundamental importância conhecer o funcionamento dos equipamentos envolvidos e desenvolver técnicas de operação e controle apropriadas. As características particulares do painel fotovoltaico, onde energia elétrica fornecida varia de acordo com a intensidade de radiação solar (sem mencionar a dependência com a temperatura), indicam a necessidade de se utilizar um controle automático que seja capaz de 
levar o consumo elétrico das células eletrolíticas o mais próximo possível do fornecimento máximo instantâneo do painel fotovoltaico.

A célula a combustível será utilizada sempre que necessário para complementar o fornecimento de energia dos painéis fotovoltaicos ou, na falta total de luz solar, para suprir toda a demanda energética do sistema. Por esse motivo, a sua potência deverá ser equivalente ao pico de consumo ao longo das 24 horas do dia, logo a célula a combustível para este sistema deverá estar apta a operar em determinada faixa de potência. Os mesmos argumentos são válidos para dimensionamento do inversor de frequência.

No trabalho realizado pelo Laboratório do Hidrogênio em Campinas, a célula a combustível adotada como referência para a reconversão do hidrogênio em energia elétrica é da empresa americana PlugPower, que fornece $3 \mathrm{~kW}$ como máxima potência de saída, opera a uma pressão de 2 bar (0,2 MPa), e apresenta um consumo de hidrogênio de $0,75 \mathrm{~m} 3 / \mathrm{kWh}$ (PLUGPOWER, 2010).

GARCIA-CONDE e ROSA (1992) apresentam uma descrição técnica de um sistema de produção de hidrogênio da energia fotovoltaica realizado na Espanha, com o objetivo de testar e verificar o uso desta tecnologia. O sistema é composto por $8,5 \mathrm{~kW}$ (potência pico) de painéis fotovoltaicos, com um sistema de controle que possibilita uma mudança na conexão dos painéis para que o fornecimento de tensão e corrente se ajuste à operação de um eletrolisador alcalino de $5,2 \mathrm{~kW}$.

GALLI e STEFANONI (1997) apresentaram um trabalho descrevendo uma montagem demonstrativa realizada na Itália de um sistema fotovoltaico/hidrogênio/célula a combustível, com o objetivo de testar o funcionamento e a eficiência dos componentes. São descritos também o sistema de armazenagem de hidrogênio em hidretos metálicos e as características e os resultados de testes da célula a combustível. Ainda são descritos os sistemas de controle e monitoramento, importante para a segurança do sistema, e uma planta da construção realizada para receber a montagem. 
ULLEBERG, 2004 e GIÖCKNER et al., 2002 publicam os resultados de dez anos de operação do sistema PHOEBUS na Alemanha, no qual demonstram a importância da estratégia de controle e operação do sistema fotovoltaico que utilizam hidrogênio como armazenador de energia elétrica. O sistema é composto por painéis fotovoltaicos com $43 \mathrm{~kW}$ de potência pico, de diferentes tipos e em diferentes inclinações, formando um barramento de $220 \mathrm{Vdc}$, acoplados a um banco de baterias com 110 células de chumbo-ácido e a um eletrolisador alcalino que opera entre 5 e $26 \mathrm{~kW}$, dimensionado para fornecer energia a um prédio (biblioteca) do centro de pesquisa. Esse sistema funcionou por 10 anos sem maiores problemas.

Na Cidade de Post Falls (EUA) uma CaC de demonstração foi instalada na NeXthouse, que é uma casa de amostra educacional para os profissionais da área de eficiência energética. A Bonneville Power Administration (BPA) criou a ideia da casa de demonstração e financiou cerca de US $\$ 800.000$, com a intenção de demonstrar ao público em geral e aos profissionais da construção, possibilidades para introdução de conceitos de eficiência energética. A casa tem inúmeras tecnologias de eficiência energética, incluindo ventilação, iluminação, isolamento térmico e orientação solar. Também inclui materiais reciclados e sistema de captação de águas, que em conjunto, são aspectos de um edifício verde (FUELCELLS 2000, 2010).

A Bonneville Power Administration (BPA) tem sede em Portland, Oregon, e é uma agência federal sob o domínio do Departamento de Energia (DOE). Operam através de uma extensa rede de transporte e comercialização de infra-estrutura de energia elétrica, por ex. barragens, instalações nucleares, hidrelétricas e instalações eólicas (BPA, 2009). A célula tipo PEM de demonstração foi produzida pela Idatech, e instalada em 1999.

A casa pertencia ao "the North Idaho Building Contractors Association 1999 Parade of Homes" e tinha parceria com a Kootenai Electric Cooperative (KEC) a maior cooperativa elétrica em Idaho, membro da sociedade energética de Hayden, Idaho. Uma empresa privada, sem fins lucrativos (KEC, 2009). A figura 26 mostra a fachada da casa, chamada de NEXTHOUSE: 


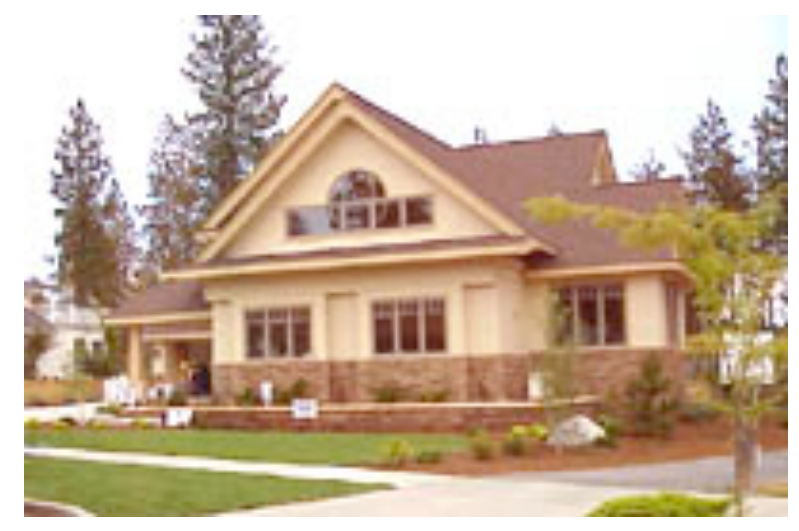

Figura 26: NEXTHOUSE.

Fonte: FUELCELLS 2000, 2012. Disponível em $<$ http://www.fuelcells.org/db/project.php?id=528>.

Em New Jersey outro protótipo foi instalado na Solar-Hydrogen Home, uma residência de 3 moradores do proprietário Mike Strizki que é engenheiro civil e desenvolveu o projeto da primeira casa norte-americana que funciona a partir da energia solar e hidrogênio desde 2006. A casa tem 15 anos e foi projetada para ser energeticamente eficiente (FUELCELL BULLETIN, 2006). A figura 27 mostra a fachada principal da casa:

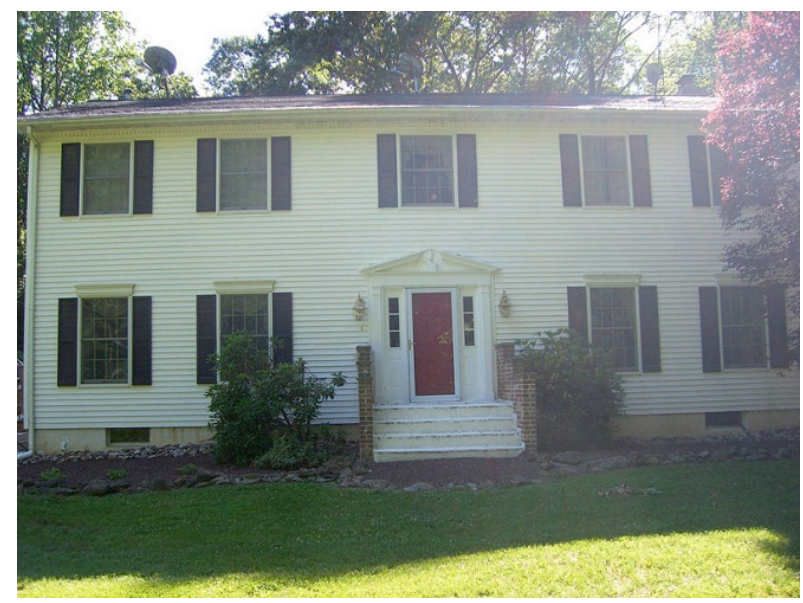

Figura 27: Fachada da Solar-Hydrogen Home

Fonte: SCIENTIFICAMERICAN, 2012. Disponível em http://www.scientificamerican.com /slideshow.cfm?id=hydrogen-house 
A célula é alimentada por painéis solares que estão localizados no telhado da garagem, o sistema pode ser conectado ou não à rede elétrica publica. O Excesso de eletricidade que é gerado durante o verão, produz hidrogênio a partir da eletrolise da água, esse hidrogênio é bombeado e armazenado em reservatórios localizados na propriedade. Nos meses mais frios, onde a energia solar enfraquece, o hidrogênio armazenado durante o verão serve para alimentar a célula combustível. A figura 28 mostra a casa no inverno, quando é a alimentada exclusivamente por hidrogênio.

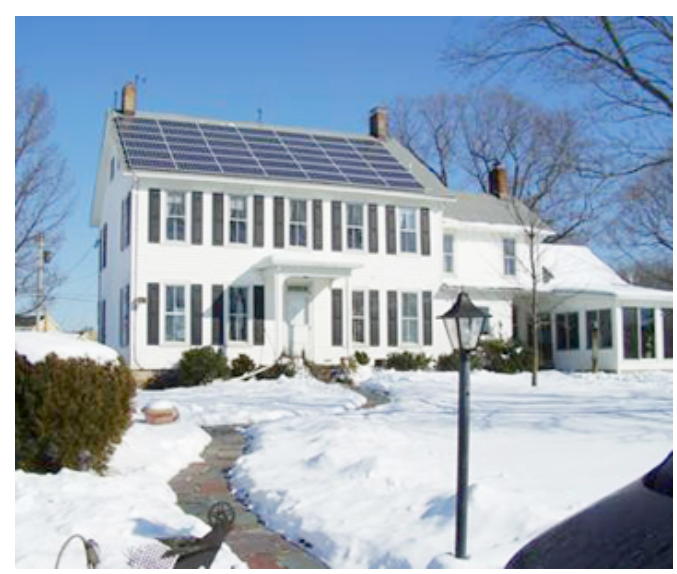

Figura 28: Solar-Hydrogen Home durante o inverno

Fonte: FUELCELLS 2000, 2012.

Disponível em http://www.fuelcells.org/db/project.php?id=959

A célula é do tio PEM de 5KW e produzida pela Plug Power, os sistemas de hidrogênio são fabricados pela Proton Energy Systems (FUELCELLS 2000, 2009).

O sistema de energia é constituído por 56 painéis solares no telhado garagem, e dentro há um pequeno eletrolizador (o dispositivo é do tamanho de uma máquina de lavar roupa) os reservatórios de hidrogênio são capazes de armazenar 538 mil metros cúbicos de hidrogênio e a célula possui um kit para poder abastecer um carro com o hidrogênio (SCIENTIFICAMERICAN, 2008). A figura 29 mostra o eletrolisador e a garagem onde esta o sistema com os painéis solares, a figura 30 mostra os tanques de armazenamento de hidrogênio na "quintal" da casa. 


\section{em residências}
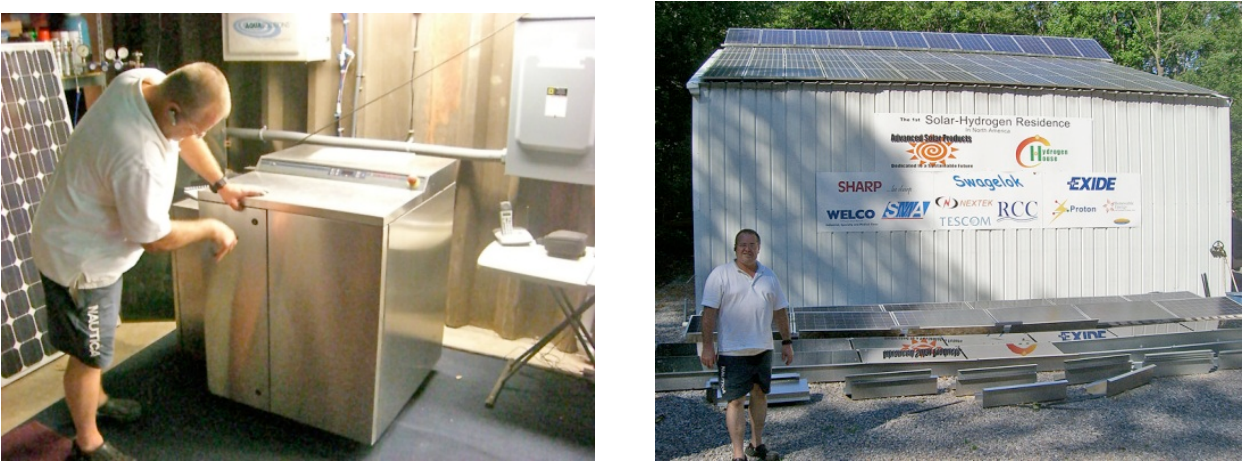

Figura 29: Eletrolisador e painéis solares.

Fonte: SCIENTIFICAMERICAN, 2012.

Disponível em http://www.scientificamerican.com/slideshow.cfm?id=hydrogen-house

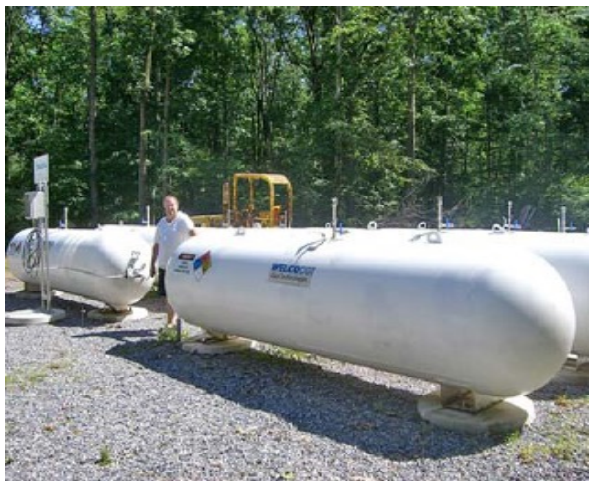

Figura 30: Tanques de hidrogênio.

Fonte: SCIENTIFICAMERICAN, 2012.

Disponível em: http://www.scientificamerican.com/slideshow.cfm?id=hydrogen-house

Como pode-se notar na figura acima os tanques de hidrogênio ficam em um local perto da casa, mas poderia ser acoplado ao design da casa, como por exemplo, nas paredes, como "recheio", ou no átrio (entre o forro e o telhado). O estado financiou US\$250.000 mil sob o Programa de Energia Limpa de Nova Jersey (Clean Energy Program). O New Jersey's Clean Energy Program (NJCEP) promove o aumento da utilização da eficiência energética aplicada em edifícios e de tecnologias de geração de energia incluindo as fontes renováveis solar, eólica, geotérmica e biomassa. O resultado é economia de energia, menos poluição e custos mais baixos. O programa oferece incentivos financeiros para aplicação dessas tecnologias em edifícios residenciais ou comerciais (NJCEP, 2009). O proprietário investiu US\$ 100.000 e o restante foi financiado a partir de empréstimos de patrocinadores de empresas privadas. 


\subsection{AПÁLISES ECONÔOICĀS}

Para avaliar um projeto é necessário armar corretamente o seu fluxo de benefícios e custos. Depois, a informação do projeto deve ser processada, com o objetivo de determinar se sua execução é ou não conveniente.

Este processamento de informação nada mais é do que o cálculo dos indicadores de rentabilidade ou viabilidade. É importante considerar que o fluxo relevante para calcular os indicadores é o dos benefícios e dos custos do projeto, ou seja, o fluxo derivado das diferenças positivas e negativas entre a situação otimizada com o projeto e sem ele.

Apesar de úteis, estes indicadores, por melhores que sejam nunca substituem a qualidade do fluxo. Se os custos e benefícios estiverem mal estimados, os indicadores não terão nenhuma utilidade (HIRSCHFELD, 2000). A seguir, são analisados os seguintes indicadores de rentabilidade:

- Valor presente líquido (VPL);

- Valor anual equivalente (VAE);

- Valor atual dos custos e custo anual equivalente (CAE);

- Taxa interna de retorno (TIR)

- Período de recuperação do investimento.

Nesse trabalho levou-se em consideração apenas o CAE, pois o VPL é um indicador utilizado quando se comparam projetos com benefícios e de difícil valorização. Eles permitem identificar a alternativa de menor custo para obter determinados resultados. O CAE é um indicador que já leva em conta o benéfico do projeto (um sistema de energia limpa, renovável, distribuída, ou seja, com valores ambientais altos). Esses indicadores podem ser utilizados para escolha do projeto que permitirá alcançar o objetivo de garantir a implantação do sistema. É exatamente por isto que se busca a alternativa de menor custo para alcance deste objetivo.

O custo anual equivalente é um dos métodos utilizados para a escolha de equipamentos que realizarão a mesma tarefa e têm vidas úteis distintas. Para o cálculo de um custo anual 
equivalente (CAE), temos que sempre levar em consideração o custo equivalente a 1 ano de produção da máquina.

O custo anual equivalente projeta (de acordo com o Fator de Correção do Capital) o capital investido para o último ano de vida útil da máquina e soma ao custo anual dessa máquina, obtendo assim o custo anual equivalente de todo o projeto. O fator de correção levará em consideração a taxa de retorno, ou taxa de custo de capital e o tempo de vida útil do equipamento.

O efeito de comparação, o que tiver o menor custo anual equivalente será o escolhido. A diferença do Custo Anual Equivalente e o Valor Anual Equivalente é que, se formos fazer um fluxo de caixa do custo anual equivalente, todas as operações terão o mesmo sinal, ou seja, é sempre saída de capital. O Valor anual equivalente tem operações de sinais diferentes, assim você obtém o lucro anual.

$\mathrm{CAE}=$ Capital Investido/Fator de Correção + Custo Anual. O fator de correção tem uma fórmula para se descobrir, igual a do VPL, mas, no caso, a questão já nos dá o fator calculado.

É o valor atual que atualiza "todos" os custos do projeto, incluídos aqui os custos de oportunidade dos fatores produtivos próprios. $O$ custo anual equivalente resulta da transformação do fluxo de todos os custos do projeto num fluxo anual uniforme (HIRSCHFELD, 2000). A fórmula seguinte relaciona estes dois indicadores:

$$
\mathrm{CAE}=\mathrm{VPC} \cdot \frac{\mathrm{n}(1+r)^{n} \cdot r}{(1+r)^{n}-1}
$$

Onde n é o tempo de duração do projeto e r é a taxa de desconto anual.

A Análise de Sensibilidade também foi utilizada. O método de análise por tendência de ocorrência dos fatos tem sido cada vez mais utilizado, tendo em vista o cenário de incertezas que permeia o mercado de investimentos. A análise de sensibilidade vem a ser um enfoque prático para tratar justamente o problema das incertezas. 
A análise de sensibilidade busca identificar em quanto um resultado financeiro, VPL, encontrado se modifica devido à variação de algum parâmetro da análise, como o preço do produto ou a quantidade vendida. Esse tipo de análise é uma opção para determinar o impacto de cada item de receita e de custo sobre a rentabilidade da atividade e para avaliar a maximização de lucros ou minimização de custos.

A análise de sensibilidade tem como objetivo auxiliar a tomada de decisão (HIRSCHFELD, 2000), ao se estudar eventuais alterações de valores produzidos por alterações nos parâmetros componentes. Ao realizar a análise, modifica-se cada variável em vários pontos percentuais acima e abaixo do valor esperado, mantendo as outras variáveis constantes. Sua relevância se dá na medida em que auxilia a identificar as variáveis que influenciam os resultados e, assim, verificar o quão sensível o investimento é a essas de acordo com a observação dos novos dados. 


\section{DEGODOLOGIA}

Primeiramente foi feita uma abordagem geral do assunto através do levantamento bibliográfico. Com algumas discussões sobre o estado da arte da aplicação de células a combustível, aplicação de $\mathrm{CaC}$ em estacionárias de pequeno porte, hidrogênio como combustível, energia fotovoltaica, a situação energética no Brasil, arquitetura bioclimática e conforto ambiental com ênfase no conforto térmico e visual.

Foi feito o levantamento climático do local escolhido (cidade de Cajobi - interior de SP) para aplicação dos conceitos de arquitetura bioclimática no modelo residencial. Para isso contase com as estações meteorológicas de cidades próximas e esses dados são retirados do INMET, CPTEC e CIIAGRO. Posteriormente são utilizadas a carta bioclimática (NBR 15220) e a carta solar para aplicação das estratégias da arquitetura bioclimática para redução do consumo energético (exclusão da utilização do ar condicionado) e conforto térmico e luminoso dos usuários.

O modelo residencial foi determinado a partir de dados do SINPHA e IBGE. Assim, classificou-se o modelo como uma residência típica da classe media brasileira, obtendo, número e tipologia dos cômodos, metragem, número de habitantes, eletrodomésticos mais utilizados, etc.

Foi determinada a demanda energética (450 kWh/mês) da edificação modelo para um cenário de acordo com a curva da demanda energética típica nacional do PROCEL. Outro cenário foi baseado na escolha dos eletrodomésticos e assim somando as potências dos eletrodomésticos chegou-se a uma potência mínima de $5 \mathrm{~kW}$ necessária para atender as necessidades da residência modelo. A casa e o sistema modelo adotado foram demonstrados em desenhos arquitetônicos (planta, corte e fachada) através do software Autocad e modelo 3D no software Sketchup e Archicad.

Ainda foram simulados vários tamanhos de células $(3,5,10$ e $15 \mathrm{~kW})$ para 0 dimensionamento do sistema de célula a combustível movida a hidrogênio solar para o mesmo 
modelo residencial, com intuito de se fazer uma comparação ressaltando vantagens e desvantagens da mudança de potência escolhida.

Para dimensionar sistemas envolvendo energia elétrica fornecida por painéis fotovoltaicos, inicialmente deve-se conhecer a incidência da radiação solar do local correspondente, bem como as informações referentes às características do consumo energético a ser atendido (FURLAN, 2008). O dimensionamento consiste no balanço entre a energia disponível e a consumida, levando em conta os rendimentos energéticos dos diferentes componentes envolvidos.

Também será descrito por tabelas o dimensionamento dos sistemas, tais quais, número de painéis solares, número e volume dos tanques de $\mathrm{H}_{2}$ necessários e potência e tamanho físico da célula a combustível por meio de um modelo matemático inicialmente proposto por uma empresa de fabricação de células combustível do Brasil (UNITECH). O modelo matemático foi desenvolvido utilizando a planilha do Microsoft Excel; nele foram introduzidas as principais características associadas aos sistemas. Foram acrescentadas informações a planilha inicial da empresa, introduzindo custos e outras análises do sistema. 


\subsection{CARACGERÍSGICASS DA RESIDÊnCIA DODELO}

No quadro 14 a seguir são demonstradas as características principais adotadas para a definição da residência modelo para posterior dimensionamento do sistema.

\begin{tabular}{|c|c|}
\hline \multicolumn{2}{|c|}{ Características } \\
\hline Tipologia & Casa \\
\hline Área da unidade $\left(\mathbf{m}^{\mathbf{2}}\right)$ & 145 \\
\hline $\mathbf{N}^{\circ}$ de quartos & 2 \\
\hline $\mathbf{N}^{\circ}$ de habitantes & 4 \\
\hline Consumo de eletricidade (kWh/mês) & 450 \\
\hline Significância no setor residencial \% & 9 \\
\hline Potência requerida (watts) & 5 \\
\hline
\end{tabular}

Quadro 14: Características finais da residência modelo.

Fonte: Elaboração própria.

\subsection{CARACGERÍSGICASS DO CONSUMO ENERGÉGICO DA RESIDÊnCIA}

O quadro 15 mostra a relação dos eletrodomésticos escolhidos que serão utilizados na residência modelo. Com essa relação é feita a soma das potências dos eletrodomésticos para chegar na potência requerida (em Watts) pela residência modelo. 


\begin{tabular}{|c|c|c|c|}
\hline Equipamento & $\begin{array}{c}\text { Tempo } \\
\text { (h) }\end{array}$ & $\begin{array}{l}\text { Potência } \\
\text { (kW) }\end{array}$ & $\begin{array}{c}\text { Consumo } \\
\text { (kWh) }\end{array}$ \\
\hline Geladeira & 24 & 0,13 & 3,1200 \\
\hline Microondas & 0,05 & 1,15 & 0,0500 \\
\hline Fogão 4 bocas & 0,03 & 0,09 & 0,0027 \\
\hline Liquidificador & 0,08 & 0,2 & 0,0160 \\
\hline Batedeira & 0,1 & 0,2 & 0,0200 \\
\hline Lava roupa & 1,3 & 1,0 & 1,3000 \\
\hline Aspirador pó & 0,08 & 0,87 & 0,0696 \\
\hline Ferro passar & 0,16 & 0,25 & 0,0400 \\
\hline TV 29' & 3 & 0,15 & 0,4500 \\
\hline $\begin{array}{c}\text { Computador } \\
\text { (2) }\end{array}$ & 4 & $0,3^{*} 2$ & 2,4000 \\
\hline DVD & 1 & 0,05 & 0,0500 \\
\hline Som & 1 & 0,08 & 0,0800 \\
\hline $\begin{array}{c}\text { Ventilador } \\
\text { (2) }\end{array}$ & 3 & $0,12 * 2$ & 1,2000 \\
\hline $\begin{array}{l}\text { Lâmpadas } \\
\qquad(12)\end{array}$ & 5 & $0,009 * 12$ & 0,5400 \\
\hline TOTAL & & 5 & 10 \\
\hline
\end{tabular}

Quadro 15: Relação dos bens de consumo, tempo de uso, potência e consumo da residência modelo. Fonte: Elaboração própria. 


\subsection{CARACGERÍSGICASS GERAIS DOS COMPONENGES UGILIZADOS NO SISGECA}

No quadro 16 são demonstrados todos os componentes utilizados para o estudo do sistema hidrogênio solar movido a célula combustível.

\begin{tabular}{|c|c|}
\hline \multicolumn{2}{|c|}{ Painéis fotovoltaicos } \\
\hline Modelo & Kyocera 245 W \\
\hline Tecnologia & policristalino \\
\hline Área $\mathrm{m}^{2}$ & 1,64 \\
\hline Peso (kg) & 21 \\
\hline \multicolumn{2}{|c|}{ Eletrolisador } \\
\hline Modelo & PEM Proton energy \\
\hline Pressao (bar) & 10 \\
\hline Quantidade de $\mathrm{H} 2$ produzida $\left(\mathrm{m}^{3}\right)$ & 0,75 \\
\hline Potencia (kW) & 5,4 \\
\hline \multicolumn{2}{|c|}{ Reservatório de $\mathrm{H} 2$ - estado gasoso } \\
\hline Cilindros & $\begin{array}{l}\text { Fina camada de aço ou alumínio envolto } \\
\text { totalmente por outros compostos como fibras } \\
\text { de carbono. }\end{array}$ \\
\hline Volume por cilindro $\left(\mathrm{m}^{3}\right)$ & 10 \\
\hline Pressão (bar) & 2 \\
\hline Potência (kW) & 5,4 \\
\hline \multicolumn{2}{|c|}{ Célula a combustível PEM } \\
\hline Potência (w) & 5 \\
\hline Consumo de $\mathrm{H} 2\left(\mathrm{~m}^{3} / \mathrm{kWh}\right)$ & 0,75 \\
\hline Pressão de operação (bar) & 2 \\
\hline
\end{tabular}

Quadro 16: Componentes utilizados no sistema de 5kW.

Fonte: Elaboração própria. 


\section{APRESENGAÇÃO G ANÁLISE DOS RESULGADOS}

Neste capítulo serão apresentados os resultados obtidos através da metodologia proposta e também a análise técnica e econômica dos sistemas estudados.

\subsection{DEFINIÇÃAO DO DODELO RESIDENCIAL GÉRREO UNIFACILIAR}

O modelo será definido a partir das tipologias mais comuns utilizadas no local de estudo na cidade de Cajobi, interior de São Paulo, que representa as casas do interior do Estado de São Paulo. Para o caso desta pesquisa são obtidas inicialmente as principais características das edificações residenciais brasileiras em levantamentos de cobertura nacional. A partir das características levantadas será composto o modelo que busca representar um perfil do setor residencial brasileiro em termos de tipologias arquitetônicas e construtivas, características econômicas e principalmente do consumo de energia.

Finalmente o modelo é descrito em suas características físicas e ocupacionais. O modelo considerado foi um protótipo de edificação residencial unifamiliar térreo representativo para a classe média brasileira. A planta da residência foi definida de acordo com dados do IBGE (Instituto Brasileiro de Geografia e Estatística) e do SINPHA (Sistema de Informações de Posses de Eletrodomésticos e Hábitos de Consumo).

\section{Parâmetros de definição}

Os parâmetros de definição do modelo foram obtidos em pesquisas de âmbito nacional cujos levantamentos informam características de tipologia arquitetônica e construtiva das edificações residenciais, além de dados sócio-econômicos. A partir dos dados da Pesquisa 
Nacional por Amostra de Domicílios - PNAD - realizada pelo IBGE (PNAD, 2009) obtiveram-se informações sobre: número de domicílios, tipologia da edificação (quanto ao tipo de domicílio, 86,9\% são casas e $12,7 \%$ apartamentos) número de habitantes, número de cômodos e posses de aparelhos eletrodomésticos. A PNAD é realizada anualmente e expandida nos anos iniciais de cada década pelos dados do Censo Demográfico. Outra fonte importante foi a Pesquisa de posse de eletrodomésticos e hábitos de consumo, que subsidia as informações do Sistema de Informações de Posses de Eletrodomésticos e Hábitos de Consumo - SINPHA - (SINPHA, 2005), realizados pela Eletrobrás, PROCEL e PUC/RJ. A Pesquisa de posse e hábitos de consumo de energia entrevistou 5.625 moradores em 284 cidades distribuídas de 18 estados e administradas por 21 concessionárias. Desta pesquisa foram publicados uma série de relatórios sobre o mercado de eficiência energética no Brasil e um simulador online que possibilita o cruzamento dos dados da pesquisa. De acordo com a pesquisa, as residências são classificadas em faixas de consumo em $\mathrm{kWh} /$ mês conforme a Tabela 01 que informa ainda o percentual de domicílios por faixa.

Tabela 01: Faixas de consumo de energia elétrica, SINPHA (2005).

\begin{tabular}{ccc}
\hline Faixa & Consumo $(\mathrm{kWh} / \mathrm{mês})$ & $\%$ de domicílios \\
\hline 1 & $0-30$ & 11,12 \\
\hline 2 & $31-50$ & 9,11 \\
\hline 3 & $51-100$ & 19,53 \\
4 & $101-150$ & 20,90 \\
5 & $151-300$ & 26,72 \\
6 & $>300$ & 12,63 \\
\hline
\end{tabular}

Fonte: SINPHA, 2005.

As relações de consumo por faixas são detalhadas para: número de habitantes, número de cômodos, área construída, renda familiar, posses de equipamentos e respectivos padrões de 
uso. Ainda são utilizados os dados do Balanço Energético Nacional - BEN - (BRASIL, 2011) de onde são retiradas informações sobre consumo de energia elétrica.

\section{Caracterização da residência}

Para traçar o perfil do consumo de energia elétrica na residência, será necessário estimar o tamanho em metros quadrados $\left(\mathrm{m}^{2}\right)$, o número de moradores e a faixa salarial. Para isso é possível contar com fontes oficiais de levantamentos nacionais disponibilizadas por órgãos do poder público. O gráfico 08 ilustra a distribuição dos domicílios por região geográfica.

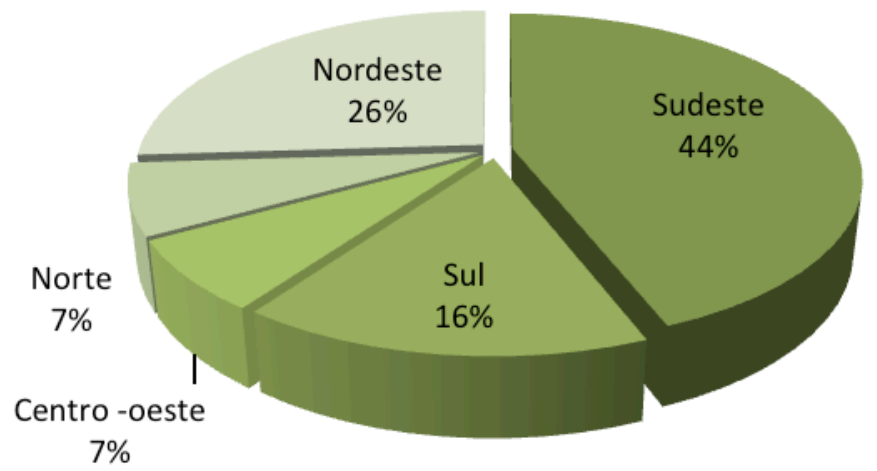

Gráfico 08: Distribuição dos domicílios por região geográfica em 2010.

Fonte: adaptado IBGE, 2011.

Observa-se que o número de domicílios permanece fortemente concentrado na região Sudeste, com 44,0\% em 2010. É possível observar que as regiões Norte e Nordeste possuem a maior proporção de habitantes por domicílio, sendo a menor a da região Sul. Para este trabalho somente são considerados os domicílios particulares e permanentes de acordo com a definição do IBGE, e que correspondem a $83,7 \%$ do total de domicílios de acordo com dados Censo mais recente, realizado em 2010 (IBGE, 2011). Domicílios particulares são aqueles destinados à habitação de uma pessoa ou pessoas com laços de parentesco ou normas de convivência, não 
sendo considerados os domicílios coletivos, tais como hotéis, pensões, asilos, quartéis e alojamentos. Permanentes são aqueles localizados em local destinado à moradia, não sendo considerados locais de moradia improvisada como salas comerciais, tendas, trailers e lojas.

De acordo com TAVARES (2006), na sua pesquisa de doutorado foi feita a constituição de um quadro das principais características encontradas nas edificações residenciais brasileiras. A tabela 02 abaixo mostra os modelos encontrados por Tavares (2006) com suas principais características e respectivas significâncias no setor residencial.

Tabela 02: Resumo das principais características dos modelos e respectivas significâncias no setor residencial.

\begin{tabular}{cccccc}
\hline Modelo & 1 & 2 & 3 & 4 & 5 \\
\hline Características & Casa & Ap. & Ap. & Casa & Casa \\
\hline Área $\left(\mathrm{m}^{2}\right)$ & 63 & 70 & 100 & 145 & 252 \\
\hline$N^{\circ}$ de dorm. & 2 & 2 & 3 & 3 & 4 \\
\hline Área do terreno & 98 & 400 & 630 & 250 & 500 \\
\hline Renda familiar & $3 \mathrm{SM}$ & $7 \mathrm{SM}$ & $10 \mathrm{SM}$ & $25 \mathrm{SM}$ & $40 \mathrm{SM}$ \\
\hline No de hab. & 4 & 2 & 3 & 4 & 5 \\
\hline Significância no setor (\%) & 58 & 20 & 10 & 9 & 3 \\
\hline Consumo de eletricidade $(\mathrm{kWh} / \mathrm{mês})$ & 140 & 160 & 240 & 450 & 650 \\
\hline
\end{tabular}

Fonte: Tavares, 2006.

O modelo proposto nesse trabalho é baseado fundamentalmente nestas informações. Os perfis ocupacionais de número de habitantes e renda domiciliar associados à área construída definem os padrões de consumo de energia elétrica. Assim, definiu-se que as características da residência modelo serão de acordo com o quadro 17. 
em residências

\begin{tabular}{|c|c|}
\hline \multicolumn{2}{|c|}{ Características } \\
\hline Tipologia & Casa \\
\hline Área da unidade $\left.\mathbf{( m}^{\mathbf{2}}\right)$ & 145 \\
\hline$N^{\circ}$ de quartos & 2 \\
\hline Renda familiar & 25 S.M. \\
\hline $\mathbf{N}^{\circ}$ de habitantes & 4 \\
\hline Consumo de eletricidade (kWh/mês) & 450 \\
\hline Significância no setor residencial \% & 9 \\
\hline Potência requerida (watts) & 5 \\
\hline
\end{tabular}

Quadro 17: Características finais da residência modelo.

Fonte: elaboração própria.

\section{Posses de equipamentos eletrodomésticos}

O consumo de energia na edificação ocorre através dos equipamentos elétricos e eletrônicos. Embora as estimativas variem segundo autores e lugares, a edificação responde por uma parcela de $30 \%$ a $40 \%$ do consumo de toda a energia mundial, sendo de $60 \%$ a $70 \%$ do uso de energia elétrica, o que acarreta de $25 \%$ a $35 \%$ da produção de CO2 (BALCOMB, 1998).

A energia elétrica consumida nos edifícios dos setores residencial, comercial e público representa mais de $42 \%$ do consumo total no Brasil de acordo com a figura (LAMBERTS, DUTRA et al., 1997). No setor residencial, predomina o consumo de energia elétrica de chuveiros, geladeiras e iluminação artificial. Esses são equipamentos comumente encontrados nos lares (alta saturação) e a eficiência energética deles influencia diretamente o comportamento do setor. Como o consumo do aparelho de ar condicionado também é influenciado pelas variáveis climáticas, seu uso final pode variar segundo as características da envoltória, a estação do ano e a região, dentre muitas outras variáveis. 


\section{em residências}

O perfil de posses e usos finais de equipamentos e aparelhos eletrodomésticos é fundamental para o consumo energético de uma edificação. Duas pesquisas foram referentes para definição do perfil utilizado no modelo. O Censo demográfico do IBGE informa a saturação de alguns equipamentos e serviços disponíveis em edificações residenciais no Brasil. A Tabela 03 informa estes dados, ou seja, os percentuais de residências que dispõem dos bens ou serviços correspondentes.

Tabela 03: Saturação de equipamentos e serviços em domicílios particulares permanentes.

\begin{tabular}{|ccc|}
\hline $\begin{array}{c}\text { Equipamento } \\
\text { /Eletrodoméstico }\end{array}$ & Domicílios (uni.) & Saturação (\%) \\
\hline Total & 44.721 .934 & 100 \\
\hline Iluminação elétrica & 41 & 93 \\
\hline Radio & 39 & 87 \\
\hline TV & 38 & 87 \\
\hline Geladeira ou freezer & 37 & 83 \\
\hline Coleta lixo & 35 & 79 \\
\hline Linha telefônica & 17 & 40 \\
\hline DVD & 15 & 35 \\
\hline Lava roupa & 14 & 33 \\
\hline Automóvel & 14 & 33 \\
\hline Micro-ondas & 8 & 19 \\
\hline Computador & 4 & 11 \\
\hline Ar condicionadao & 3 & 7 \\
\hline
\end{tabular}

Fonte: IBGE, 2010.

A partir de dados do SINPHA foi elaborada a Tabela 04 onde se apresentam as posses dos principais eletrodomésticos presentes em domicílios brasileiros. Os índices de posses são obtidos dividindo o número de equipamentos pelo número residências levantados na pesquisa. 
em residências

Tabela 04: Posses de equipamentos eletrodomésticos em domicílios brasileiros.

\begin{tabular}{|c|c|}
\hline Aparelhos & Médias \\
\hline TV & 1,37 \\
\hline Ferro passar & 0,93 \\
\hline Refrigerador & 0,89 \\
\hline Ventilador & 0,84 \\
\hline Liquidificador & 0,82 \\
\hline Som & 0,81 \\
\hline Chuveiro elétrico & 0,52 \\
\hline Lava roupas & 0,43 \\
\hline DVD & 0,41 \\
\hline Batedeira & 0,37 \\
\hline Microondas & 0,22 \\
\hline Cafeteira & 0,21 \\
\hline Secadora roupas & 0,21 \\
\hline Aspirador pó & 0,20 \\
\hline Freezer & 0,17 \\
\hline Exaustor & 0,16 \\
\hline computador & 0,14 \\
\hline Lava louça & 0,10 \\
\hline Ar condicionado & 0,08 \\
\hline
\end{tabular}

Fonte: adaptado de SINPHA (2005).

Com base nas tabelas apresentadas do IBGE e SINPHA, estimou-se os bens de consumo da residência modelo para determinacação da curva de demanda energética.

\section{Estimativa dos bens de consumo}

A estimativa dos bens de consumo foi realizadas baseada nos dados do SINPHA, ano base de 2005 e do IBGE. A energia elétrica consumida nas edificações ocorre através dos sistemas prediais como iluminação, ar condicionado, aquecimento de água (torneiras e chuveiros) e 
equipamentos em geral. Consequentemente, os equipamentos elétricos e eletrônicos tendem a ser os principais objetos de análises que visam a minimizar o consumo de energia.

Entretanto, o consumo acontece devido às interações desses sistemas com a envoltória (elemento arquitetônico) e os usuários, conforme Baird (1984). O consumo de energia elétrica que ocorre nos equipamentos pode ser influenciado pelo clima. Por isso, há edificações que variam seu consumo de energia de forma mais expressiva do que outros, ao decorrer dos meses. Como exemplo tem-se as medições do consumo horário de energia elétrica de um dos edifícios analisados em Florianópolis durante o Projeto 6 Cidades (THOMÉ, LAMBERTS et al., 1998), observou-se que o consumo reduzia drasticamente à medida que o clima esfriava. O consumo de energia elétrica de microcomputadores, iluminação artificial e equipamentos elétricos em geral não dependem do clima. Seu consumo depende da eficiência elétrica e do período que o equipamento é usado.

Para a escolha dos equipamentos que serao utilizados na residência modelo levou-se em consideraçao as pesquisas em cima de dados do IBGE e SINPHA. Alguns comentários sobre os equipamentos são listados abaixo:

$\checkmark$ Aparelho de TV - a faixa de consumidor número 5 e 6, segundo o SINPHA (2005) traz a presença da televisão como $97 \%$ dos domicílios e essas acima de 29 polegadas. $\checkmark$ Ar condicionado -.Nota-se que para faixa de consumo 5 (301 a $500 \mathrm{kWh} / \mathrm{mês}$ ), se houver ar condicionado, esse é ligado mais de 4 vezes semanais, ou seja, tem um consumo grande. Em relação a potência do ar condicionado a porcentagem maior utiliza de 7500 BTU/h. Algumas considerações sobre a intensidade do uso do ar condicionado devem ser mencionadas, como por exemplo, que os dados apontaram que no clima ameno, 2,8\% fazem uso de 1 a 3 vezes por semana, 5,2 \% uso regular, em clima frio $81,6 \%$ declaram não fazerem uso do equipamento, em climas quentes $34,3 \%$ mencionaram fazer uso grande e $23,1 \%$ uso médio ( 2 ou 3 vezes na semana).

$\checkmark$ Chuveiros - o aquecimento de água é feito através de chuveiros elétricos, de acordo com as pesquisas (IBGE, 2010; SINPHA, 2005). Em relação à utilização dos chuveiros 
elétricos foram analisadas opções que variam entre 1 a 7 banhos por dia e mais de 8 banhos para a faixa de consumo 5 . Estima-se que para a faixa 5 de consumo são 8 banhos (2 por habitante) com duração de 15 minutos.

$\checkmark$ Freezer - A frequência de uso do freezer fica estipulada como permanente (24 horas por dia) de acordo com SINPHA (2005).

$\checkmark$ Refrigerador - Fica estipulado o uso permanente de 1 refrigerador de 200 a 300 litros, de acordo com SINPHA.

Através dos equipamentos citados, montou-se um quadro com as informações referentes ao equipamento utilizado, o tempo de uso e a potência do equipamento. Os dados referentes a potência (em watts) do equipamento foram retirados do PROCEL. O quadro 18 mostra a relação dos nes de consumo escolhidos para residência modelo.

\begin{tabular}{|l|l|l|l|}
\hline Equipamento & $\begin{array}{l}\text { Tempo } \\
\text { (h) }\end{array}$ & $\begin{array}{l}\text { Potência } \\
\text { (kW) }\end{array}$ & $\begin{array}{l}\text { Consumo } \\
\text { (kWh) }\end{array}$ \\
\hline Geladeira & 24 & 0,13 & 3,1200 \\
\hline Microondas & 0,05 & 1,15 & 0,0500 \\
\hline Fogão 4 bocas & 0,03 & 0,09 & 0,0027 \\
\hline Liquidificador & 0,08 & 0,2 & 0,0160 \\
\hline Batedeira & 0,1 & 0,2 & 0,0200 \\
\hline Lava roupa & 1,3 & 1,0 & 1,3000 \\
\hline Aspirador pó & 0,08 & 0,87 & 0,0696 \\
\hline Ferro passar & 0,16 & 0,25 & 0,0400 \\
\hline TV 29' & 3 & 0,15 & 0,4500 \\
\hline $\begin{array}{l}\text { Computador } \\
(2)\end{array}$ & 4 & $0,3^{*} 2$ & 2,4000 \\
\hline DVD & 1 & 0,05 & 0,0500 \\
\hline Som & 1 & 0,08 & 0,0800 \\
\hline $\begin{array}{l}\text { Ventilador } \\
(2)\end{array}$ & 3 & $0,12^{*} 2$ & 1,2000 \\
\hline $\begin{array}{l}\text { Lâmpadas } \\
(12)\end{array}$ & 5 & $0,009^{*} 12$ & 0,5400 \\
\hline TOTAL & & 5 & 10 \\
\hline
\end{tabular}

Quadro 18: Relação dos bens de consumo, tempo de uso, potência e consumo da residência modelo.

Fonte: Elaboração própria. 


\section{Características locais}

A caracterização do clima da região e seus dados climáticos são instrumentos imprescindíveis de avaliação no planejamento e construção de uma edificação. Os dados climáticos influenciam o desempenho da edificação sob o aspecto da transferência de calor através dos diversos materiais da estrutura, que alteram as condições dentro do ambiente interno em termos da temperatura, radiação solar, ventilação, umidade e variáveis bioclimáticas.

Cajobi é um município brasileiro do estado de São Paulo. A cidade tem uma população de 9.768 habitantes (IBGE/2010). Localizada na região norte do estado, fica a aproximadamente 430 km da capital São Paulo. Está a uma altitude de 565 metros. O sítio sobre o qual se implantou a cidade caracteriza-se por um relevo pouco ondulado com espigões amplos e de modesta altitude, em média $500 \mathrm{~m}$. Suas coordenadas geográficas são latitude sul $20^{\circ} 52^{\prime} 48^{\prime \prime}$ e longitude Oeste $48^{\circ} 48^{\prime} 32^{\prime \prime}$. A cidade faz parte da Microrregião de Catanduva e da Mesorregião de São José do Rio Preto. Tem Área de 176,9 km² (IBGE/2010).

A cidade está localizada entre as rodovias principais Washington Luiz SP - 310 Estadual, e a rodovia Armando Salles Oliveira SP - 322, de acordo com a figura 31 a seguir.

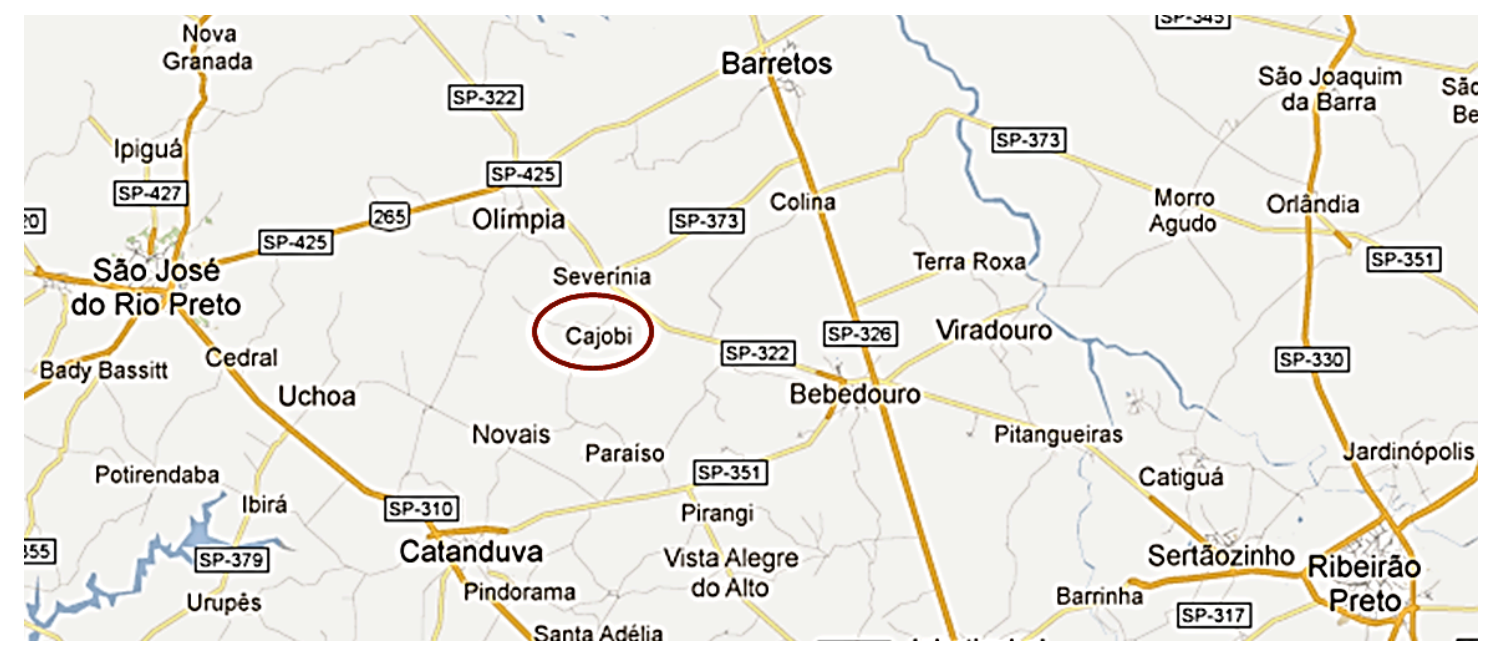

Figura 31: Mapa da região de São José do Rio Preto.

Fonte: Google Maps, 2013. 
As regiões a Noroeste, mais quentes, pertencem ao tipo Aw, tropical chuvoso com inverno seco e mês mais frio com temperatura média superior a $18^{\circ} \mathrm{C}$. O mês mais seco tem precipitação inferior a $60 \mathrm{~mm}$ e com período chuvoso que se atrasa para o outono pela Classificação climática de Köppen-Geiger.

Nimer (1979) relata que fatores de ordem estática e natureza dinâmica se combinam para definir os processos climatológicos da Região Sudeste, onde está situada São José do Rio Preto (aproximadamente $50 \mathrm{~km}$ em linha reta) e recebe influências das perturbações climáticas típicas dessa região. Segundo o mesmo autor, a Região Sudeste está localizada sob a trajetória preferida das frentes polares e, frequentemente, o sistema de circulação do anticiclone polar das altas latitudes e o sistema de circulação dos anticiclones do Atlântico Sul das baixas latitudes se combinam em equilíbrio dinâmico, fato que caracteriza a diversificação do clima da região.

De acordo com Monteiro (1973), o território paulista é vulnerável à ação das principais correntes da circulação atmosférica da América do Sul. As massas Tropical Atlântica e Continental, Polar Atlântica e Equatorial Continental, juntamente com os fatores geográficos de posicionamento e relevo, contribuem para definir as características de climas tropicais alternadamente secos e úmidos. A umidade relativa do ar média anual se situa na casa dos $70 \%$ aproximadamente, podendo chegar até abaixo de $20 \%$ nos meses mais secos. Nessa classificação da figura 32 , mais detalhada para o estado de São Paulo, a cidade de Cajobi também recebe classificação de tropical chuvoso. 


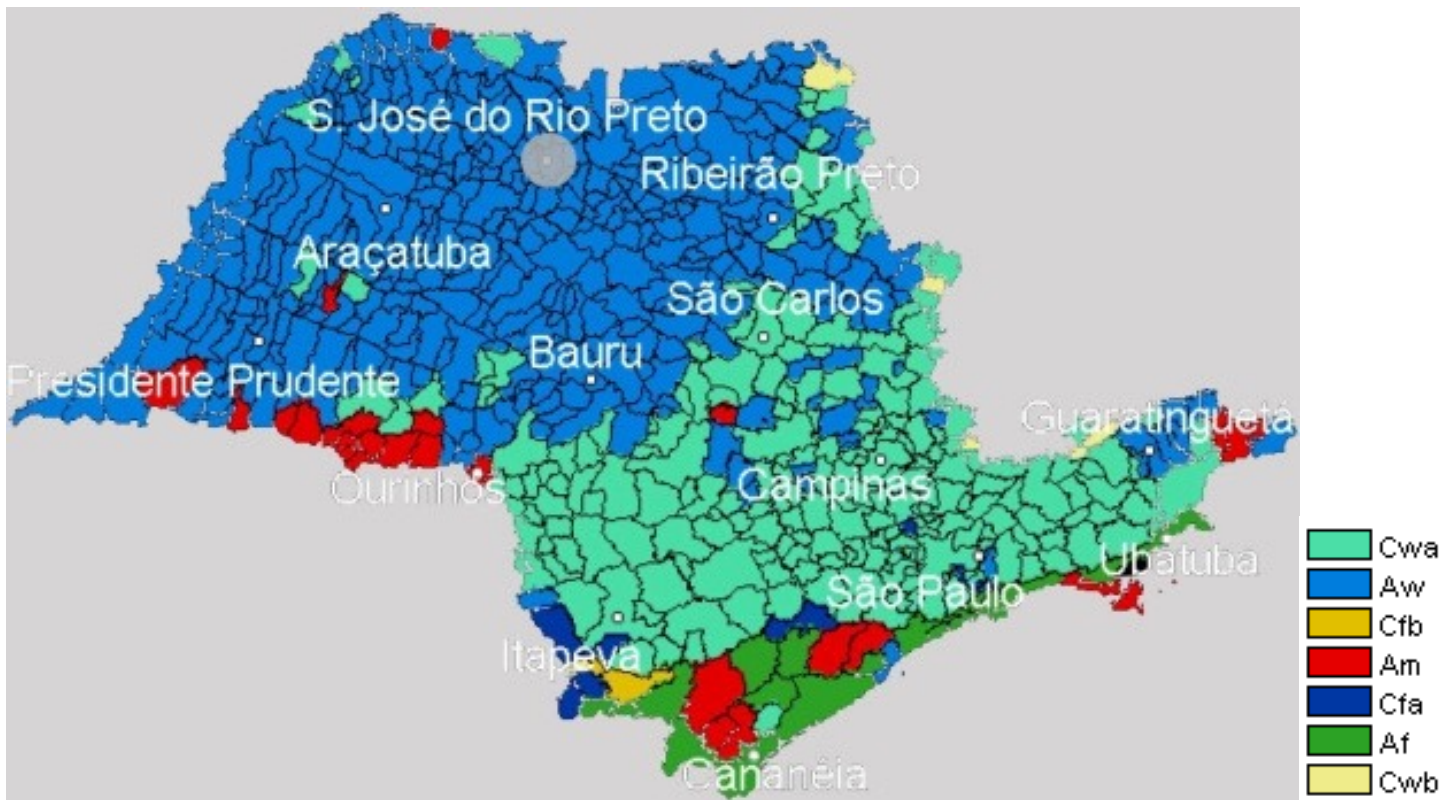

Figura 32: Classificação Climática de Koppen no Estado de São Paulo

Fonte: CEPAGRI, 2010 - Adaptado de Koppen.

Toda a cidade de Cajobi caracteriza-se por uma zona de ocupação mista entre atividade comercial, de serviços e residencial, de baixa densidade com total predomínio de habitações unifamiliares, a Figura 33 mostra a cidade.

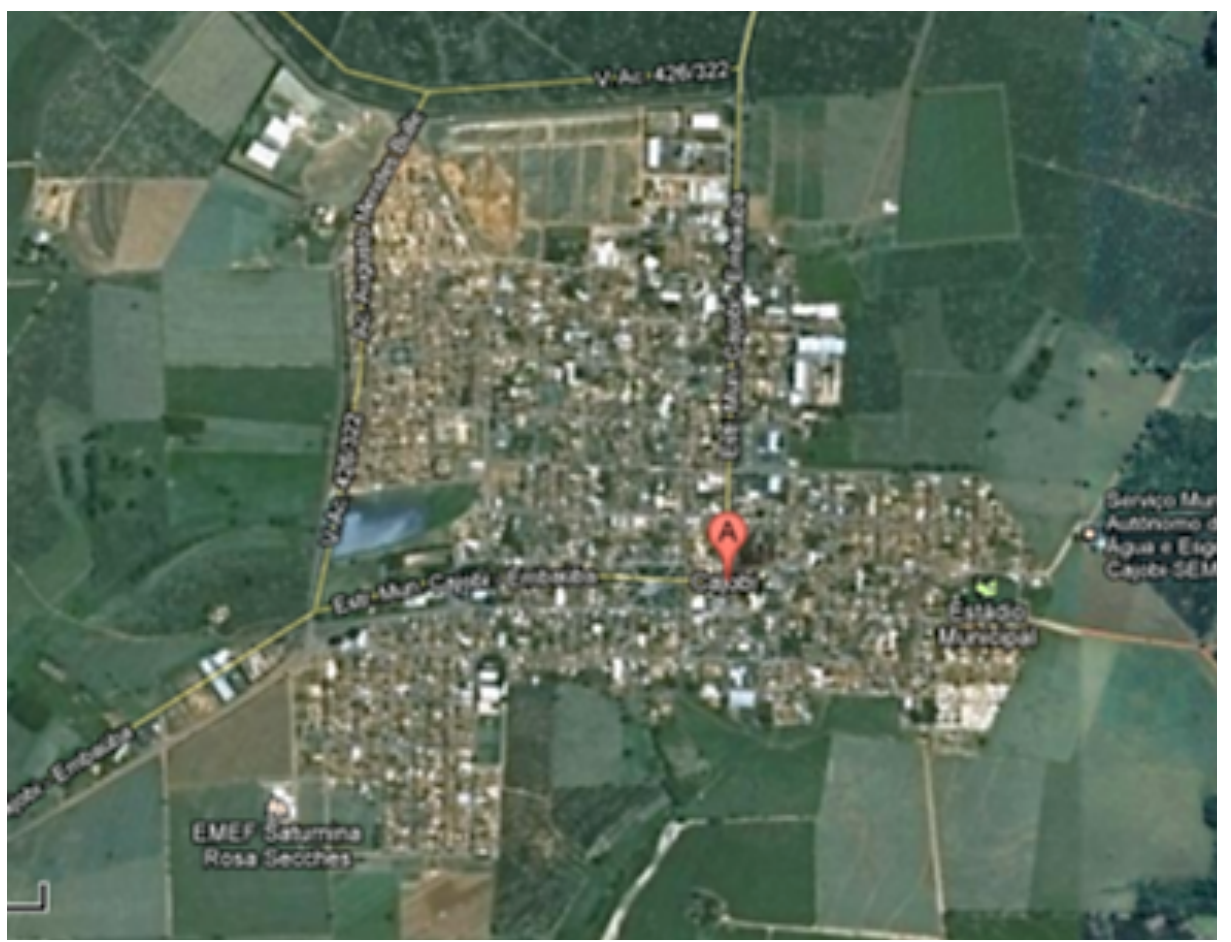

Figura 33: Vista aérea da cidade de Cajobi.

Fonte: Google Maps, 2014. 
A área de estudo está localizada perto da represa da cidade, onde será alocado um bairro residencial novo, ainda em fase de loteamento. Prevê-se um bairro residencial de baixa densidade com predomínio de habitações unifamiliares. A figura 34 mostra a vista panorâmica da cidade, a flecha laranja indica a localização do terreno.

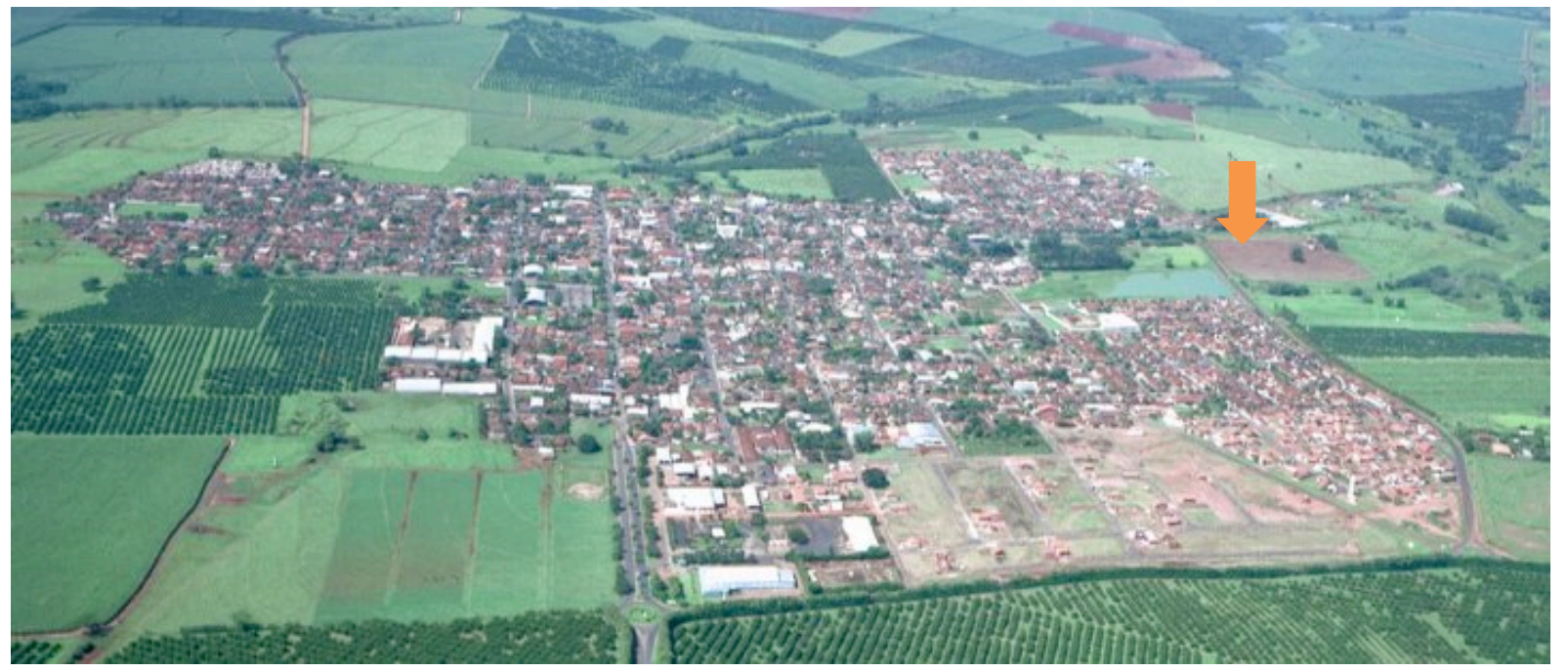

Figura 34: vista panorâmica de Cajobi.

Fonte: Prefeitura Municipal de Cajobi, 2012.

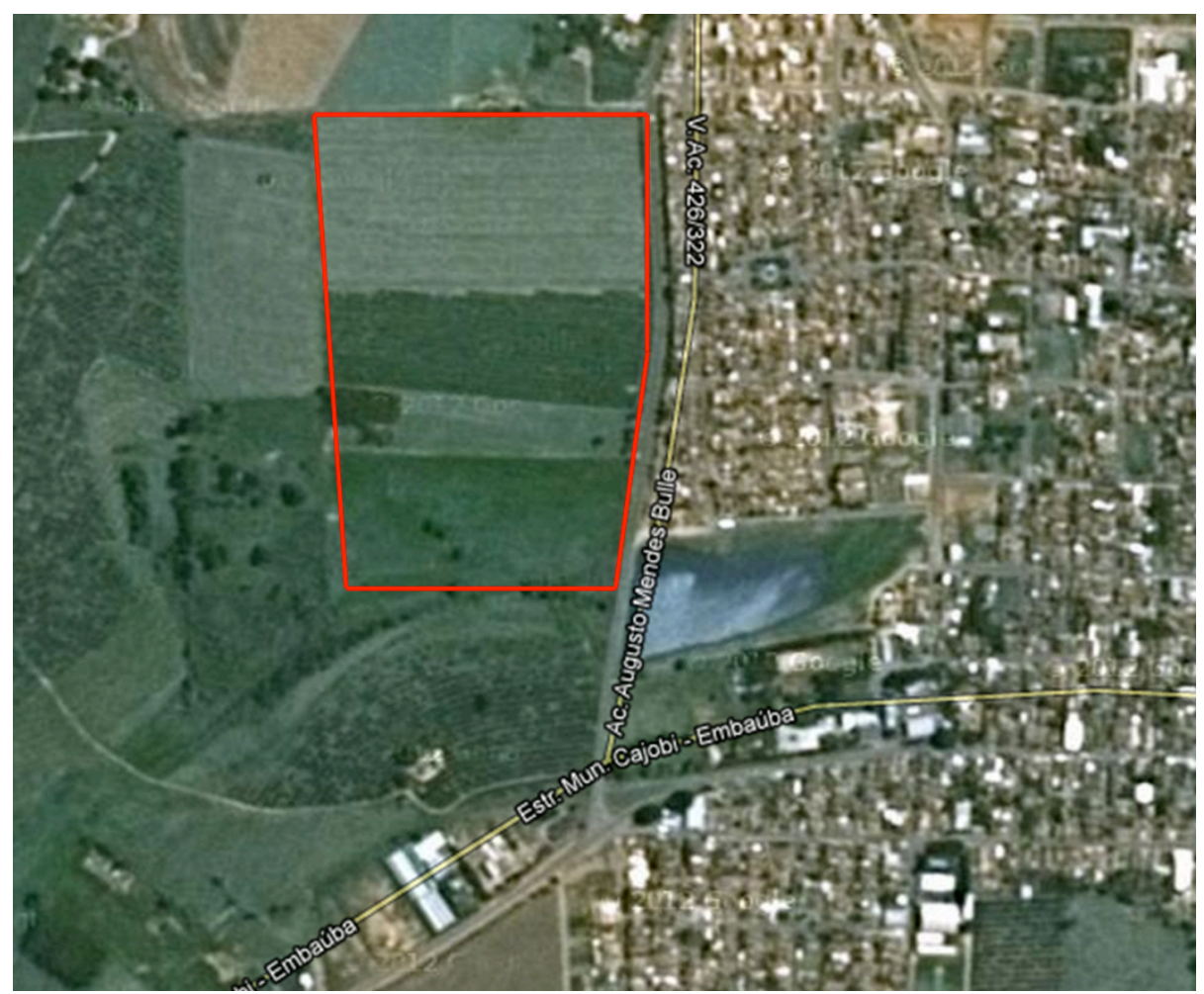

Figura 35: Vista da região de estudo.

Fonte: Google Maps, 2014. 
A figura 35 mostra a área de estudo circulada em vermelho. A figura 36 é a projeção do local no software autocad. A área em laranja corresponde a área de estudo, que fica próxima ao centro da cidade, mas é cortada por um anel viário que passa pela cidade.

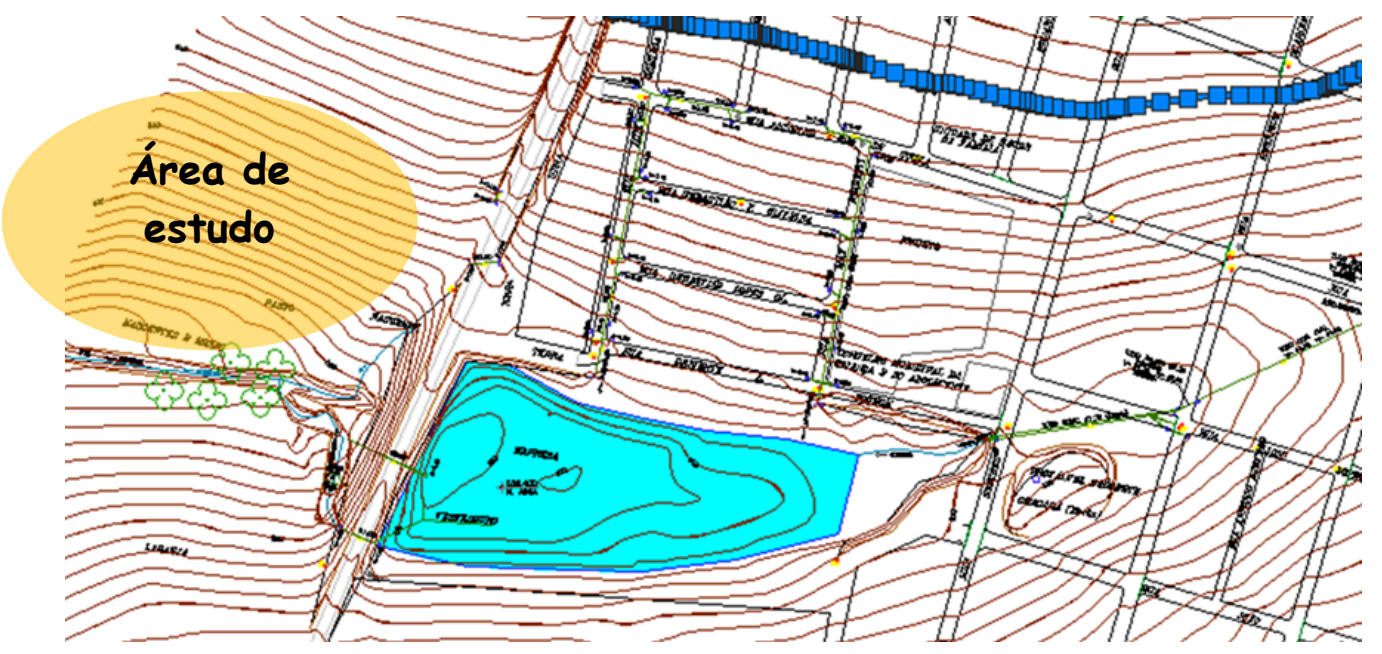

Figura 36: Projeção do local no software autocad.

Fonte: Arquivo pessoal.

A figura 37 é o projeto para o novo loteamento que será chamado Ecoville, um bairro predominantemente residencial.

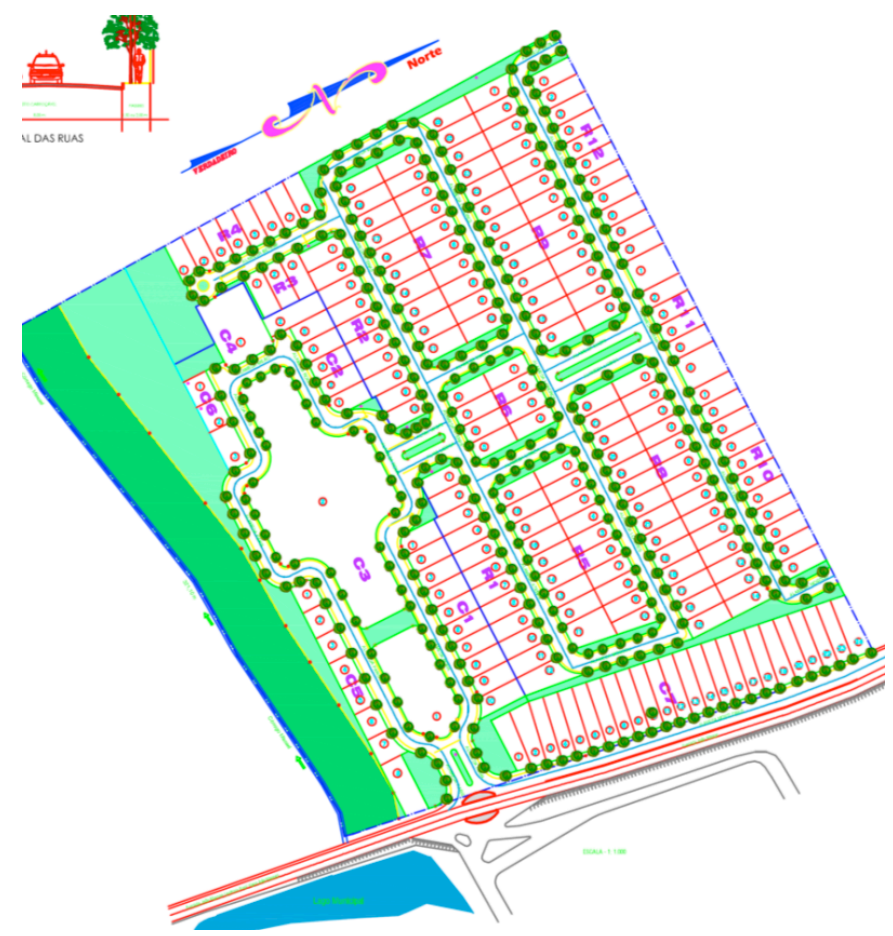

Figura 37: Planta do loteamento Ecoville em Cajobi.

Fonte: Arquivo pessoal. 


\section{Gemperatura}

A temperatura do ar está diretamente relacionada com a chegada de energia solar à superfície do planeta. As temperaturas máximas ocorrem, normalmente, entre 14 e 15 horas e as mínimas, ao nascer do sol. Outro fator relevante na variação da temperatura é a latitude. A amplitude térmica cresce com o aumento da latitude, e a altitude também é importante, pois com o seu aumento a temperatura tende a diminuir. A variação diária da temperatura do ar está relacionada com a absorção da radiação solar pela superfície da Terra. Os fatores que mais influenciam nas variações térmicas são: a época do ano, a posição geográfica, o tipo de cobertura, a cor das superfícies, dentre outras. O clima do município é tropical semi-úmido, com verões quentes úmidos e invernos secos e amenos. A temperatura média no inverno é de $17^{\circ} \mathrm{C}$ e no verão é de $26^{\circ} \mathrm{C}$. A precipitação média do mês mais seco é inferior a $60 \mathrm{~mm}$. A temperatura média anual é de $24,1^{\circ} \mathrm{C}$. O quadro 18 mostra os dados gerais da temperatura cidade de Cajobi.

\begin{tabular}{|c|c|c|c|}
\hline \multirow{2}{*}{ Mês } & \multicolumn{3}{|c|}{ Temperatura do ar $\mathbf{( c}^{\circ} \mathbf{~}$} \\
\hline & Min média & Max média & Média \\
\hline Jan & 19.2 & 30.5 & 24.8 \\
\hline Fev & 19.3 & 30.6 & 25.0 \\
\hline Mar & 18.7 & 30.5 & 24.6 \\
\hline Abr & 16.2 & 29.4 & 22.8 \\
\hline Mai & 13.6 & 27.7 & 20.6 \\
\hline Jun & 12.3 & 26.7 & 19.4 \\
\hline Jul & 13.4 & 29.6 & 21.5 \\
\hline Ago & 15.5 & 30.8 & 23.2 \\
\hline Set & 15.5 & 30.8 & 23.2 \\
\hline Out & 17.2 & 30.8 & 24.0 \\
\hline Nov & 17.8 & 30.6 & 24.2 \\
\hline Dez & 18.7 & 30.2 & 24.5 \\
\hline Ano & 16.1 & 29.5 & 22.8 \\
\hline Min & 11.8 & 26.7 & 19.4 \\
\hline Max & 19.3 & 30.8 & 25.0 \\
\hline
\end{tabular}

Quando 19: Temperatura e precipitações de Cajobi.

Fonte: CPA, UNICAMP, 2013. Disponível em: <http://www.cpa.unicamp.br/outras-informacoes/clima_muni_106.html> Acesso em 7 jul.2013. 


\section{Radiação solar}

O sol é um elemento de extrema importância nos estudos de eficiência energética na arquitetura, tendo como premissas básicas o conforto térmico e visual e o consumo reduzido de energia. Tendo em vista que a máxima radiação solar que chega à superfície da Terra é em torno de $1.000 \mathrm{~W} / \mathrm{m} 2$, a média da radiação solar para Cajobi é de $5,07 \mathrm{kWh} / \mathrm{m}^{2}$ (CRESESB, 2012). O quadro 19 mostra a radiação diária média para as localidades mais próximas da cidade de Cajobi (latitude $20,50^{\circ}$ sul e longitude $48,48^{\circ}$ norte).

\begin{tabular}{|l|l|l|l|l|l|l|l|l|l|l|l|l|}
\hline \multicolumn{10}{|c|}{ Radiação diária média (kWh/m². dia) } \\
\hline Jan & Fev & Mar & Abr & Mai & Jun & Jul & Ago & Set & Out & Nov & Dez & Méd. \\
\hline 5.58 & 5.67 & 5.58 & 4.44 & 4.28 & 4.08 & 4.44 & 4.83 & 4.83 & 5.83 & 5.81 & 5.44 & 5.07 \\
\hline
\end{tabular}

Quadro 20: Radiação Média Diária para as localidades próximas de Cajobi.

Fonte: CRESESB, 2012. Disponível em http://www.cresesb.cepel.br/sundata/index.php\#sundata

De todas as variáveis climáticas, a radiação solar é a que tem o comportamento mais conhecido, bastando traçar os ângulos de azimute e de altitude solar, para saber onde está o sol em determinado período do ano. Existem vários métodos para representar as trajetórias aparentes do sol, destacando-se o ortográfico, o equidistante e o estereográfico.

\section{Umidade}

A umidade do ar é dita relativa, porque se relaciona com a sua temperatura. Isto se dá de forma diretamente proporcional, ou seja, quanto maior a temperatura do ar, maior sua capacidade de conter umidade. Em locais com alta umidade, a transmissão de radiação solar é reduzida, porque o vapor de água e as nuvens a absorvem e redistribuem na atmosfera, refletindo uma parte de volta ao espaço; assim, as temperaturas extremas tendem a ser atenuadas. O quadro 20 foi extraída do Software Arquitrop e traz a umidade relativa do ar para cidade de Pindorama, próxima a Cajobi. 


\begin{tabular}{|c|c|c|c|c|c|c|c|c|c|c|c|c|c|}
\hline $\begin{array}{c}\text { UR } \\
\text { \% }\end{array}$ & Jan & Fev & Mar & Abri & Mai & Jun & Jul & Ago & Set & Out & Nov & Dez & Ano \\
\hline & 79 & 72 & 77 & 73 & 72 & 68 & 61 & 57 & 60 & 62 & 69 & 77 & 69 \\
\hline
\end{tabular}

Quadro 21: Dados climáticos para cidade de Pindorama.

Fonte: adaptado ARQUITROP, Roriz.

Nota-se pelo arquitrop que a média anual de UR é de $69 \%$, correspondendo com a classificação de Koppen AW, os meses de julho e agosto referem-se aos meses de "seca", onde se deve evitar a entrada dos ventos.

\section{Ventos}

Nos climas quentes e úmidos a dimensão horizontal de uma edificação deve ser alongada e perpendicular aos ventos dominantes, objetivando a maximização das trocas de calor por convecção. As massas edificadas devem ficar sempre em exposição direita ao vento e as massas arbustivas e liquidas na posição contrária. Quanto ao caminho aparente do Sol, devem-se evitar as declividades voltadas para oeste.

Os ventos predominantes, segundo a INMET provém do sul, sudeste e sudoeste. A velocidade média sazonal dos ventos, segundo a CRESESB, para as coordenadas geográficas da cidade de Cajobi são de dezembro a fevereiro de 4,44 m/s, de março a maio de 5,58 m/s, de junho a agosto de 6,62 e de setembro a outubro de 6,30 m/s (CRESESB, 2014).

\section{Chuvas}

As menores quantidades de chuvas ocorrem durante os meses de julho e agosto, onde ocorrem as maiores velocidades de ventos. Nos meses de Dezembro, Janeiro e Fevereiro ocorrem às chuvas de verão com índices de até $246,9 \mathrm{~mm}$, de acordo com o quadro 21 


\begin{tabular}{|c|c|c|c|c|c|c|c|c|c|c|c|c|c|c|c|}
\hline Mês & Jan & Fev & Mar & Ab & Mai & Jun & Jul & Ago & Set & Out & Nov & Dez & Ano & Min & Max \\
\hline Chuvas & 246,9 & 203,7 & 184,6 & 66,3 & 43,3 & 23,3 & 18,8 & 21,5 & 46,1 & 108,1 & 151,9 & 222,7 & 1337,2 & 18,8 & 246,9 \\
\hline
\end{tabular}

Quadro 22: Temperatura e precipitações de Cajobi.

Fonte: CPA, UNICAMP, 2013. Disponível em: < http://www.cpa.unicamp.br/outrasinformacoes/clima_muni_106.html>.

\section{Aplicação da Carta bioclimática (nRB 15220)}

Pelo fato da cidade de Cajobi apresentar-se com um clima quente e semiúmido, ter verões chuvosos e inverno seco, o controle do clima interno deve ser bem considerado. Deve-se buscar a utilização adequada de conceitos e parâmetros de projeto mais próxima possível das condições climáticas da região em estudo, de maneira a amenizar naturalmente o ambiente interno da edificação durante quase todo o ano, e minimizar a necessidade de condicionamento térmico por meio artificial.

OLGYAY (1963) buscou, dentro de uma sequência de variáveis interdependentes (clima, biologia, tecnologia, arquitetura), encontrar o método que compreende, inicialmente, uma análise de dados climáticos, acompanhada de uma avaliação psicobiológica. Isso resultou na elaboração da primeira carta bioclimática apropriada para ambiente externo, apresentando-se como uma tentativa de associar os dados climáticos com a sensação de conforto. O uso da carta é apropriado a regiões com menos de 300 m (1.000 pés) de altitude em relação ao nível do mar, e latitude de até aproximadamente 40 graus, em zonas de clima moderado. Posteriormente, GIVONI (1969) propôs uma metodologia que utilizou o índice de estresse térmico para avaliar os requerimentos humanos para o conforto. Essa metodologia envolve os seguintes passos: análise do clima; opções para aquisição de condições internas para conforto em climas quentes; e traçado das variáveis climáticas na carta psicrométrica. Também afirmou que o método de Olgyay é limitado em sua aplicabilidade, uma vez que a análise dos requerimentos fisiológicos está baseada no clima externo e não no microclima esperado no interior da edificação em 
questão. Posteriormente, no seu trabalho mais recente (1992), explica que pessoas que moram em edifícios naturalmente ventilados aceitam variações grandes de temperatura e velocidade do ar, demonstrando assim, que o clima interno nos edifícios não climatizados mecanicamente reage mais largamente à variação do clima externo.

De acordo com a NBR 15220 o país foi dividido em 8 zonas bioclimáticas, da qual a cidade de Cajobi está inserida na zona 6 . A figura 38 mostra as 8 zonas bioclimáticas e uma lista com cidade de Catanduva como referência da zona 6.

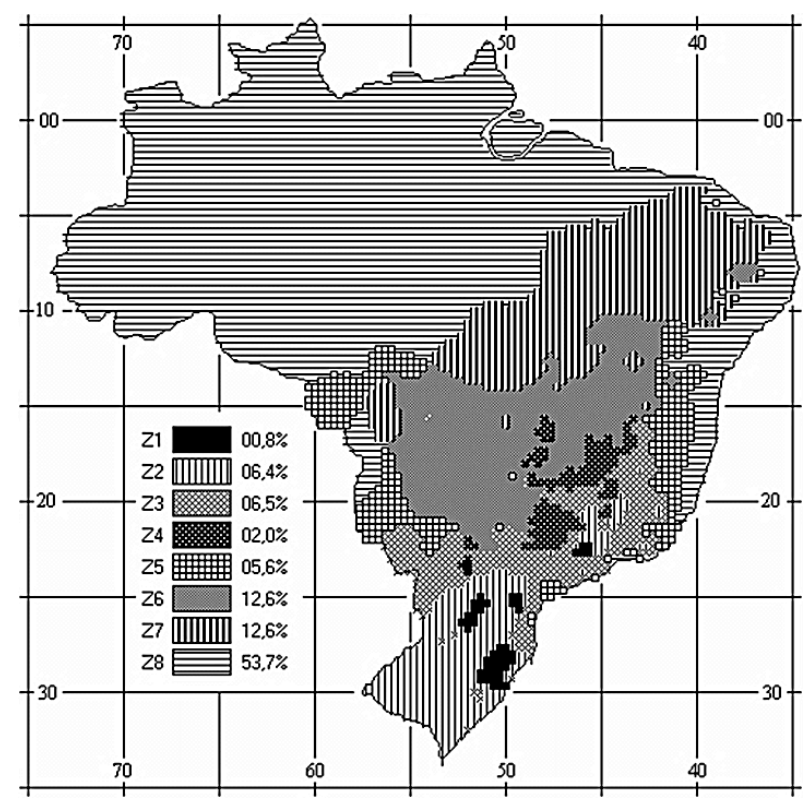

Figura 38: Mapa das zonas bioclimáticas brasileiras e lista com algumas dessas cidades e suas respectivas zonas e estratégias de projeto.

Fonte: ABNT, 2005.

Os quadros 22, 23 e 24 trazem as recomendações de estratégias de condicionamento térmico passivo para a zona bioclimática 06 que a NBR 15220 indica.

\section{Aberturas para ventilação Sombreamento das aberturas \\ Médias Sombrear aberturas}

Quadro 23: Aberturas para ventilação e sombreamento das aberturas para zona 6.

Fonte: ABNT, 2005. 


\section{Vedações externas \\ Parede: pesada \\ Cobertura. Leve isolada}

Quadro 24: Tipos de vedações externas para zona 6

Fonte: ABNT, 2005.

\begin{tabular}{|c|c|}
\hline Estação & Estratégias de condicionamento térmico passivo \\
\hline \multirow[t]{2}{*}{ Verão } & H) resfriamento evaporativo e massa térmica para resfriamento \\
\hline & $\begin{array}{c}\text { J) ventilação seletiva (nos períodos quentes em que a temperatura interna seja } \\
\text { superior a externa) }\end{array}$ \\
\hline Inverno & C) vedações internas pesadas (inércia térmica) \\
\hline
\end{tabular}

Quadro 25: Estratégias de condicionamento térmico passivo para zona bioclimatica 6.

Fonte: ABNT, 2005.

\subsubsection{Descrição do modelo residencial}

Uma edificação que tem dentre os seus objetivos principais, a obtenção de eficiência energética, o uso racional da energia elétrica e uma economia representativa de energia deve, desde o início de seu processo de concepção e planejamento, estabelecer e aplicar conceitos e métodos que conduzam a tais objetivos. Existem, dentro desse processo, quatro passos básicos e estratégicos que abrangem a totalidade do projeto, que são:

- A expressão arquitetônica (simbologia);

- O estudo das variáveis climáticas (arquitetura bioclimática);

- Os efeitos do clima no ser humano (conforto térmico);

- As soluções tecnológicas (funcionalidade).

Assim, uma edificação concebida de acordo com esses conceitos, responderá de forma adequada a uma arquitetura eficiente energeticamente e aos requerimentos necessários para a obtenção de uma economia energética e de conforto térmico. 
Neste capítulo, são analisados esses princípios básicos e os principais parâmetros que foram levados em conta para o projeto arquitetônico do modelo, dando um enfoque especial às variáveis bioclimáticas e suas relações com a edificação projetada.

\section{Características físicas}

A arquitetura bioclimática consiste em fazer a análise da influência dos fatores climáticos nos espaços e na aplicação de tecnologia baseada na utilização de elementos arquitetônicos adequados à região, derivando-se a partir daí as principais estratégias a serem aplicadas para obter uma ótima eficientização energética e fornecer ao ambiente construído um alto grau de conforto higrotérmico e com menor consumo energético.

Visando a este objetivo, o projeto permite a inclusão gerenciada do clima através do aproveitamento da insolação, iluminação e ventilação natural disponíveis. Esta inclusão, no entanto, é feita com o cuidado de garantir uma redução de cargas térmicas supérfluas, incidentes sobre as paredes externas, mediante a análise de orientação, sombreamento, escolha de materiais e redução das cargas térmicas internas (iluminação e equipamentos).

A edificação tem seu eixo principal voltado para o norte e sul, que são as direções mais fáceis de controlar a radiação solar nos períodos mais quentes, não possui construções muito próximas ou obstáculos que impeçam a incidência de vento e radiação solar, devido à sua localização favorável (parte alta da cidade). Através do diagrama de sombras feito inicialmente, é analisada a influência do sol nas fachadas, durante o ano todo.

$\mathrm{Na}$ fachada leste está a garagem e o banheiro da suíte, na fachada sul ficaram as janelas do dormitório, o que não foi muito favorecido, pois nos meses mais frios não recebe sol nessa fachada. Na fachada norte (a mais privilegiada) ficaram a sala e a cozinha ambientes de maior permanência, e na fachada oeste (a pior em radiação solar, pois recebe o sol mais forte do horário da tarde) ficou a varanda e a área de serviço com teto verde para maior resistência térmica. 
Devido à adequada orientação da edificação em relação ao percurso do sol, nota-se que, de forma geral, o prédio recebe pouca radiação solar direta sobre suas fachadas principais ou nas partes de maior comprimento, recebendo-a apenas nas áreas menores, orientadas para o oeste com dimensões menores favorecendo o tratamento das mesmas para evitar o sobreaquecimento e facilitando a projeção de protetores solares.

\section{Gécnicas arquitetônicas}

A obtenção de temperaturas mais baixas possíveis nos ambientes internos dos edifícios, em climas quentes, em todas as horas ou especialmente naquelas em que a temperatura do ar é mais elevada, é o principal objetivo de criar um ambiente mais confortável. A boa orientação do edifício, o sombreamento das fachadas isoladas, a seleção criteriosa e a técnica correta de emprego dos materiais de vedação e cobertura são meios empregados para este fim.

Propõe-se em termos construtivos, trabalhar com materiais que propicie de um lado conforto ambiental e economia energética, e por outro, uma construção rápida, "limpa" e sem desperdícios. Foram utilizados materiais convencionais na estrutura e vedação da residência, para compor uma casa "típica" brasileira, apenas levando em conta as estratégias que a NBR 15220 e a 15575 pedem.

O edifício tem uma cobertura a duas águas, com uma inclinação de $25^{\circ}$ propiciando um desague rápido e evitando o sobre-aquecimento ao criar um colchão de ar. As aberturas de ventilação superiores tipo lanternim, são distribuídas uniformemente no telhado para saída de ar quente e, aliadas a abertura do telhado contribuem significativamente para os processos de ventilação natural do edifício. São utilizados materiais adequados às características climáticas da região, como telha de barro, isolamento térmico e forro, para evitar os ganhos solares por transmissão. O quadro 26 mostra a relação de portas e aberturas escolhidas e suas porcentagens necessárias de acordo com a NBR 15220. 


\begin{tabular}{|c|c|c|c|}
\hline Ambiente & $\begin{array}{c}\% \text { da } \\
\text { abertura no } \\
\text { ambiente }\end{array}$ & Tipo de abertura & Descrição \\
\hline \multirow[t]{2}{*}{$\begin{array}{l}\text { Sala de tv } \\
\text { Área: } 13,83 \\
m^{2}\end{array}$} & $\begin{array}{l}\text { Janela de } \\
\text { madeira } \\
(1,50 \mathrm{~m} \times \\
2,00 \mathrm{~m}) \\
21,70 \% \text { de } \\
\text { abert. }\end{array}$ & $\begin{array}{l}\text { की } \\
\text { जी } \\
\end{array}$ & $\begin{array}{l}01 \text { janela de madeira } 1,50 \times 2,00-\text { a janela } \\
\text { oferece resistência mecânica (tração e } \\
\text { compressão), baixa condutibilidade térmica, além } \\
\text { de ser um material renovável e natural. }\end{array}$ \\
\hline & $\begin{array}{l}\text { Porta de } \\
\text { madeira } \\
(2,10 \mathrm{~m} x \\
1,00 \mathrm{~m}) \\
15,18 \% \text { de } \\
\text { abert. }\end{array}$ & & $\begin{array}{l}\text { Porta de madeira 1,00 × } 2,10 \text { - a porta oferece } \\
\text { resistência mecânica (tração e compressão), baixa } \\
\text { condutibilidade térmica, além de ser um material } \\
\text { renovável e natural. }\end{array}$ \\
\hline \multirow[t]{2}{*}{$\begin{array}{l}\text { Dormitório } \\
\text { ii } \\
\text { Área: } 14,00 \\
\mathrm{~m}^{2}\end{array}$} & $\begin{array}{l}\text { Janela de } \\
\text { madeira } \\
(1,50 \mathrm{~m} x \\
2,00 \mathrm{~m}) \\
21,43 \% \text { de } \\
\text { abert. }\end{array}$ & & $\begin{array}{l}01 \text { janela de madeira } 1,50 \times 2,00 \text { - a janela } \\
\text { oferece resistência mecânica (tração e } \\
\text { compressão), baixa condutibilidade térmica, além } \\
\text { de ser um material renovável e natural. }\end{array}$ \\
\hline & $\begin{array}{l}\text { Porta de } \\
\text { madeira } \\
(2,10 \mathrm{~m} x \\
0,80 \mathrm{~m}) \\
12 \% \text { de abert. }\end{array}$ & & $\begin{array}{l}\text { Porta de madeira } 0,80 \text { × } 2,10 \text { - a porta oferece } \\
\text { resistência mecânica (tração e compressão), baixa } \\
\text { condutibilidade térmica, além de ser um material } \\
\text { renovável e natural. }\end{array}$ \\
\hline \multirow[t]{2}{*}{$\begin{array}{l}\text { Suíte } \\
\text { Área: } 16,00 \\
\mathrm{~m}^{2}\end{array}$} & $\begin{array}{l}\text { Janela de } \\
\text { madeira } \\
(1,50 \mathrm{~m} x \\
2,00 \mathrm{~m}) \\
18,75 \% \text { de } \\
\text { abert. }\end{array}$ & & $\begin{array}{l}01 \text { janela de madeira } 1,50 \times 2,00 \text { - a janela } \\
\text { oferece resistência mecânica (tração e } \\
\text { compressão), baixa condutibilidade térmica, além } \\
\text { de ser um material renovável e natural. }\end{array}$ \\
\hline & $\begin{array}{l}\text { Porta de } \\
\text { madeira } \\
(2,10 \mathrm{~m} x \\
0,80 \mathrm{~m}) \\
10,50 \% \text { de } \\
\text { abert. }\end{array}$ & & $\begin{array}{l}\text { Porta de madeira } 0,80 \times 2,10 \text { - a porta oferece } \\
\text { resistência mecânica (tração e compressão), baixa } \\
\text { condutibilidade térmica, além de ser um material } \\
\text { renovável e natural. }\end{array}$ \\
\hline $\begin{array}{l}\text { Bwc suite } \\
\text { Área: } 4,85 \\
\mathrm{~m}^{2}\end{array}$ & $\begin{array}{l}\text { Janela de } \\
\text { madeira } \\
(0,50 \mathrm{~m} x \\
1,40 \mathrm{~m}) \\
14,43 \% \text { de } \\
\text { abert. }\end{array}$ & & $\begin{array}{l}01 \text { janela de madeira } 0,50 \times 1,40-\text { a janela } \\
\text { oferece resistência mecânica (tração e } \\
\text { compressão), baixa condutibilidade térmica, além } \\
\text { de ser um material renovável e natural. }\end{array}$ \\
\hline
\end{tabular}




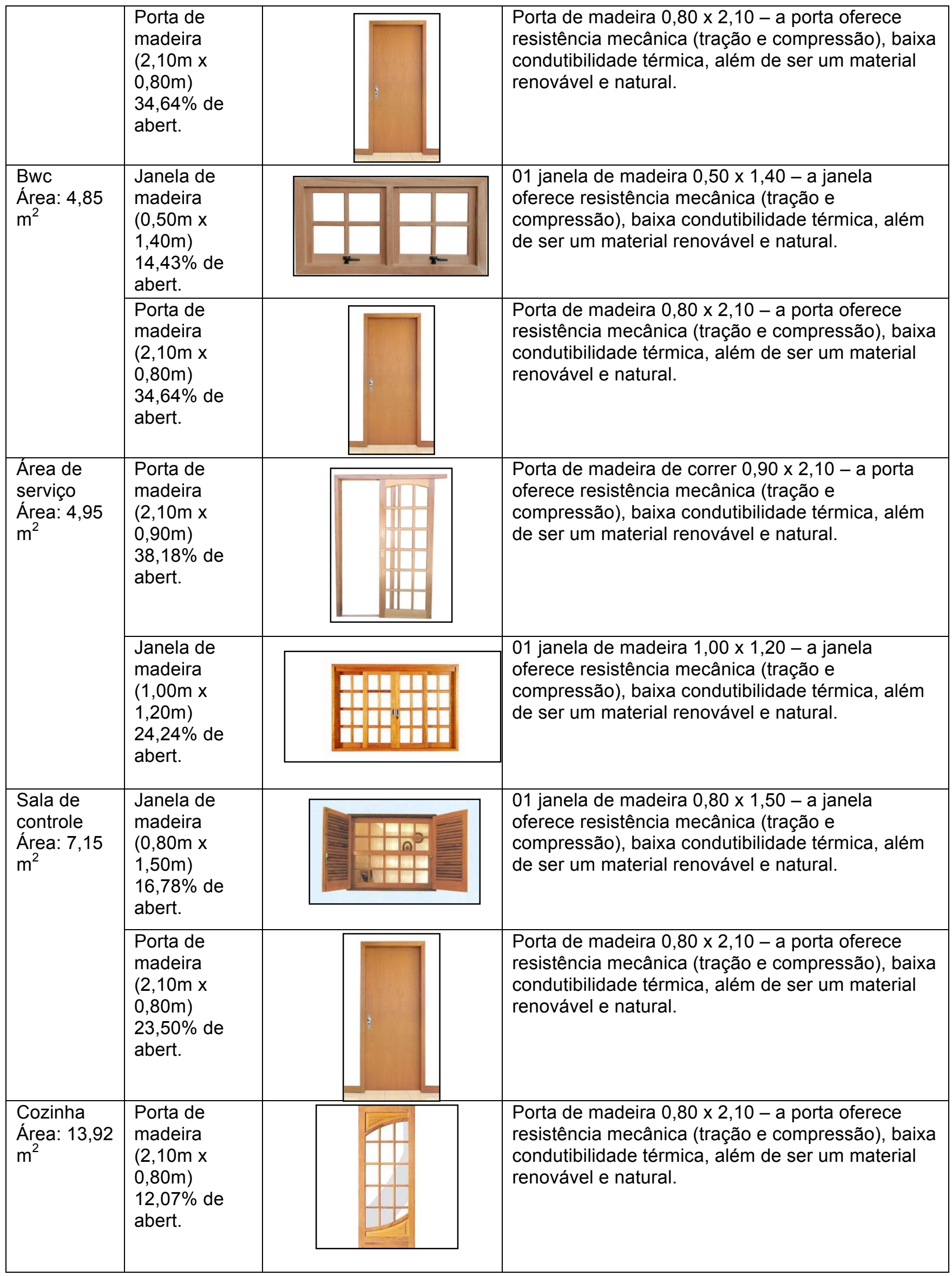




\begin{tabular}{|l|l|l|l|}
\hline $\begin{array}{l}\text { Janela de } \\
\text { madeira } \\
(1,20 \mathrm{~m} x \\
1,80 \mathrm{~m}) \\
15,52 \% \text { de } \\
\text { abert. }\end{array}$ & $\begin{array}{l}01 \text { janela de madeira 1,20 x 1,80 - a janela } \\
\text { oferece resistência mecânica (tração e } \\
\text { compressão), baixa condutibilidade térmica, além } \\
\text { de ser um material renovável e natural. }\end{array}$ \\
\hline
\end{tabular}

Quadro 26: Tipologias das aberturas.

Fonte: Elaboração própria.

O quadro 27 mostra o tipo de material utilizado de acordo com a NBR 15220.

\begin{tabular}{|c|c|c|c|c|}
\hline $\begin{array}{l}\text { Materiais } \\
\text { utilizados }\end{array}$ & Descrição & $\begin{array}{c}\text { Transmitância } \\
\text { térmica } \\
\mathrm{U}\left[\mathrm{w} /\left(\mathrm{m}^{2 \cdot} \mathrm{K}\right)\right]\end{array}$ & $\begin{array}{c}\text { Atraso } \\
\text { térmico } \\
\text { em horas }\end{array}$ & Foto do material \\
\hline Paredes & $\begin{array}{l}\text { Parede de tijolos de } 8 \text { furos } \\
\text { assentados na maior dimensão } \\
\text { Espessura de argamassa de } \\
\text { assentamento: } 1 \mathrm{~cm} \\
\text { Espessura de argamassa de } \\
\text { emboço: } 2,5 \mathrm{~cm} \\
\text { Espessura total da parede: } 25 \mathrm{~cm}\end{array}$ & 1,61 & 5,9 & \\
\hline Cobertura & $\begin{array}{l}\text { Cobertura com estrutura de madeira } \\
\text { em telha de barro pintada de branco } \\
\text { para refletir o calor e deixar os } \\
\text { ambientes mais frescos } \\
\text { Espessura: } 1 \mathrm{~cm}\end{array}$ & 1,92 & 3,6 & \\
\hline Forro & $\begin{array}{l}\text { Forro de madeira, pois a madeira é } \\
\text { um isolante térmico, deixando os } \\
\text { ambientes mais frescos no verão e } \\
\text { mais aquecidos no inverno. } \\
\text { Espessura: } 1 \mathrm{~cm}\end{array}$ & & & \\
\hline
\end{tabular}

Quadro 27: Tipos de materiais utilizados.

Fonte: elaboração própria.

As aberturas são laterais feitas nas paredes onde, naturalmente, o maior aproveitamento luminoso ocorre perto das janelas, com um grande declínio na medida que se afasta delas. A iluminação direta só predomina nas proximidades das janelas; assim, a claridade dos locais é determinada pelo grau de reflexão das superfícies que a limitam.

Nas paredes escuras a curva decresce mais rápido; por isso, a tonalidade cromática definitiva é decidida em função da iluminação natural, pois não existem locais que usem 
exclusivamente luz artificial. A figura 39 mostra um detalhe do telhado onde a abertura lateral ajuda na ventilação e iluminação dos quartos.

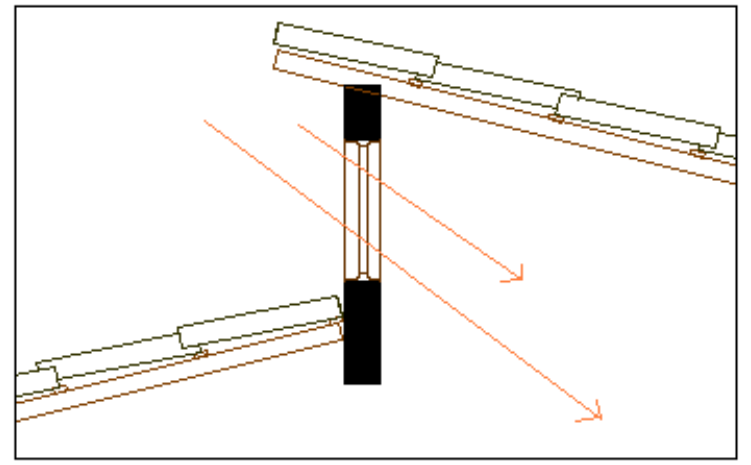

Figura 39: Abertura para melhor iluminação e ventilação natural. Fonte: Elaboração própria.

Recomenda-se pintura de cores claras (de preferência branca) para forros e paredes externas e internas; esta produz uma melhor refletância da radiação solar e, portanto, menos calor atravessará os fechamentos, minimizando os ganhos solares e também favorecendo um ótimo aproveitamento da luz e a propagação da luz natural nos espaços.

\section{Iluminação natural}

A quantidade de luz natural recebida pela edificação em todos os espaços depende da incidência de luz solar indireta e/ou refletida, pois ele não recebe radiação solar direta nas suas fachadas mais afetadas pelo sol (oeste e norte) durante o ano todo, as aberturas da fachada oeste são protegidas por uma varanda com teto verde para maior resistência térmica da cobertura. As aberturas da fachada sul, não estão protegidas, apesar dessas receberem sol durante o verão, porem pode-se colocar toldos ou brises.

Na projeção de sombras realizada confirma-se que não existe radiação solar direta que atinja as aberturas projetadas; somente durante algumas horas do dia será necessário proteger 
alguns espaços com beiras ou protetores solares, que evitem a radiação solar direta e permitam a ventilação adequada.

O objetivo do projeto é utilizar a iluminação natural por ser de melhor qualidade, gratuita, e, portanto sem custos nem desperdícios, complementando-a com a iluminação artificial sempre que as necessidades de conforto luminoso o solicitarem, sendo esta proveniente, do sistema hidrogênio solar

$\mathrm{Na}$ edificação, a radiação solar não atinge diretamente os espaços internos ocupados nos horários de insolação excessiva, e não apresenta problema de ofuscamento; assim, os sistemas de iluminação natural estão determinados por dois itens: quantidade suficiente e boa distribuição, colocando as tarefas que mais requerem concentração, sempre que for possível, perto das janelas. Assim, o uso permite até $35 \%$ de redução no consumo de energia para iluminação em relação a edifícios não iluminados naturalmente e um efeito positivo sobre os ganhos de calor internos na edificação.

Para um adequado funcionamento da edificação e o conforto dos seus usuários, é preciso garantir uma iluminação mínima de 150 lux, entre as 8 horas e 16 horas em 100\% dos dias do ano.

\section{Ventilação natural}

A ventilação de conforto (com função de resfriamento fisiológico) é aplicável e indicada devido à ocorrência de temperaturas médias máximas altas, atingindo temperaturas absolutas máximas em torno de $36^{\circ} \mathrm{C}$ e apresentando um alto teor de umidade relativa no ar no verão.

Assim as altas temperaturas e umidade produzem desconforto e opta-se pela ventilação cruzada como principal estratégia, mediante a circulação de ar pelos ambientes da edificação, apoiada pela diferença de volumes, que permite o acesso dos ventos nos diferentes blocos,

visando sempre que cada espaço fique favorecido. Isto significa que, por exemplo, se o ambiente tiver janelas em apenas uma fachada, a porta deveria ser mantida aberta para permitir 
a ventilação cruzada. Também se deve atentar para o aproveitamento adequado dos ventos dominantes e entorno, pois este pode alterar significativamente a direção dos ventos.

Segundo a analise das medições feitas pra a cidade, de velocidade e direção dos ventos, a edificação permitirá tratamento adequado para recepção e direcionamento dos ventos. Nas análises derivadas da carta bioclimática, determina-se a ventilação cruzada como principal estratégia para a zona 6 sem a necessidade de ar condicionado.

A forma de climatização mais adequada é a climatização mista (ora natural, ora artificial) onde o uso de aparelhos de ventilação seja setorial e esporádico, por decisão do usuário, motivado por questões de conforto higrotérmico e eventualmente acústico, mostrando assim que a integração entre sistemas naturais e artificiais é a maneira mais adequada para obter o conforto térmico ao longo de todo o ano.

Como resposta a esta estratégia, orienta-se a edificação ao comportamento dos ventos e pode-se perceber que não existem obstáculos que impeçam a entrada do vento, pois os desníveis na cobertura e o direcionamento de suas águas produzem uma grande movimentação no telhado, criando áreas importantes de sombreamento e ventilação. Assim, a edificação esta adotando igualmente aberturas adequadas para captar os ventos. Segundo LAMBERTS (1997) as aberturas devem ser generosas, de forma a captar o vento e permitir a ventilação cruzada dos espaços internos. Também é importante o emprego de proteções solares nas aberturas, evitando os ganhos de calor. Pode-se optar também pelas aberturas zenitais, tendo um cuidado especial, pois, embora as aberturas sejam a solução adequada, devem ser passíveis de isolamento e estanqueidade.

\section{Implantação, planta, cortes e fachadas}

A figura 40 mostra a implantação da casa modelo. A figura 41 mostra a planta. A figura 42 mostra a planta de cobertura. As figuras 43 e 44 correspondem aos cortes. As figuras 45, 46, 47 e 48 mostram as fachadas (leste, norte, oeste e sul) da residência modelo. 


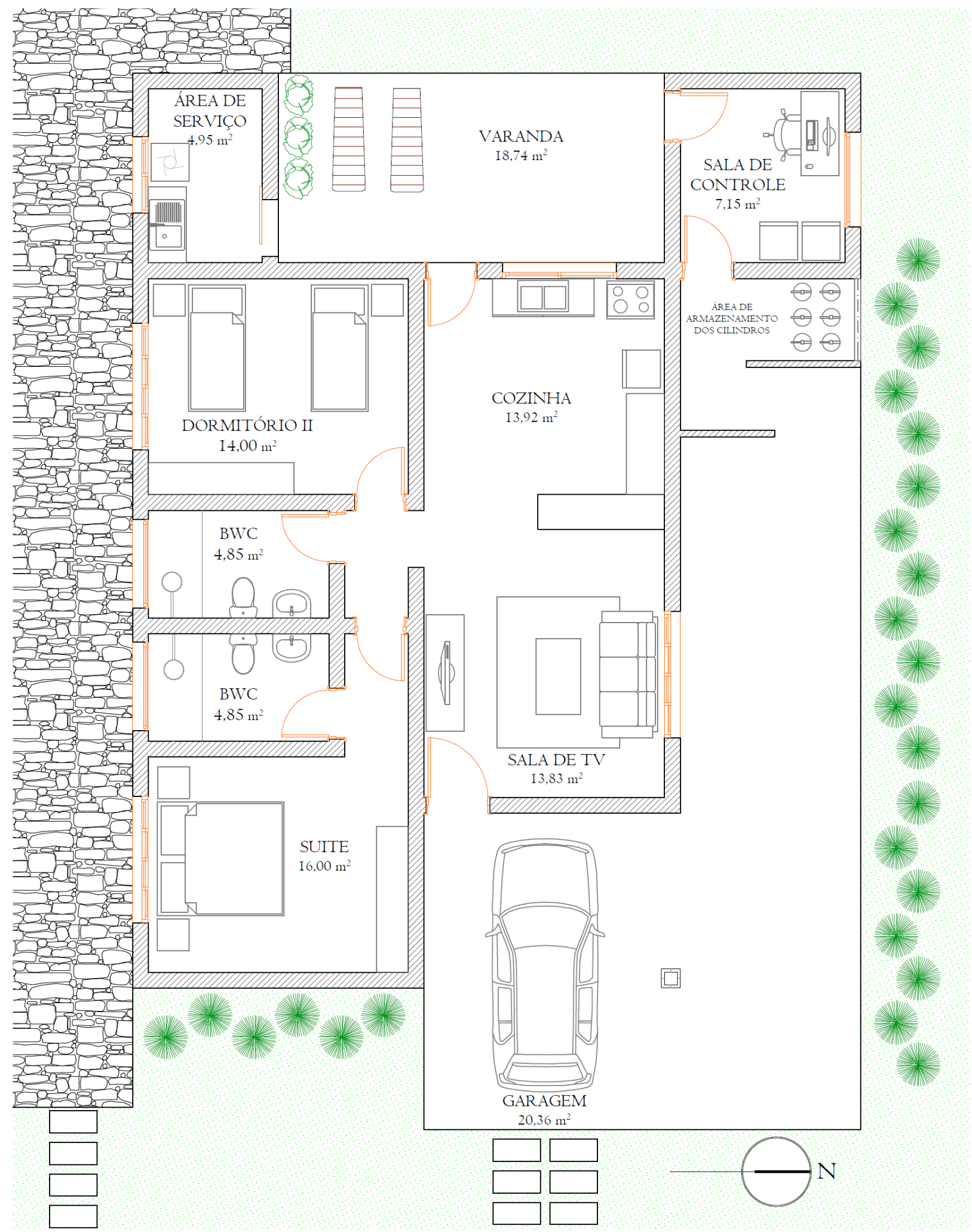

Figura 40: Implantação da residência.

Fonte: Elaboração própria. 
em residências

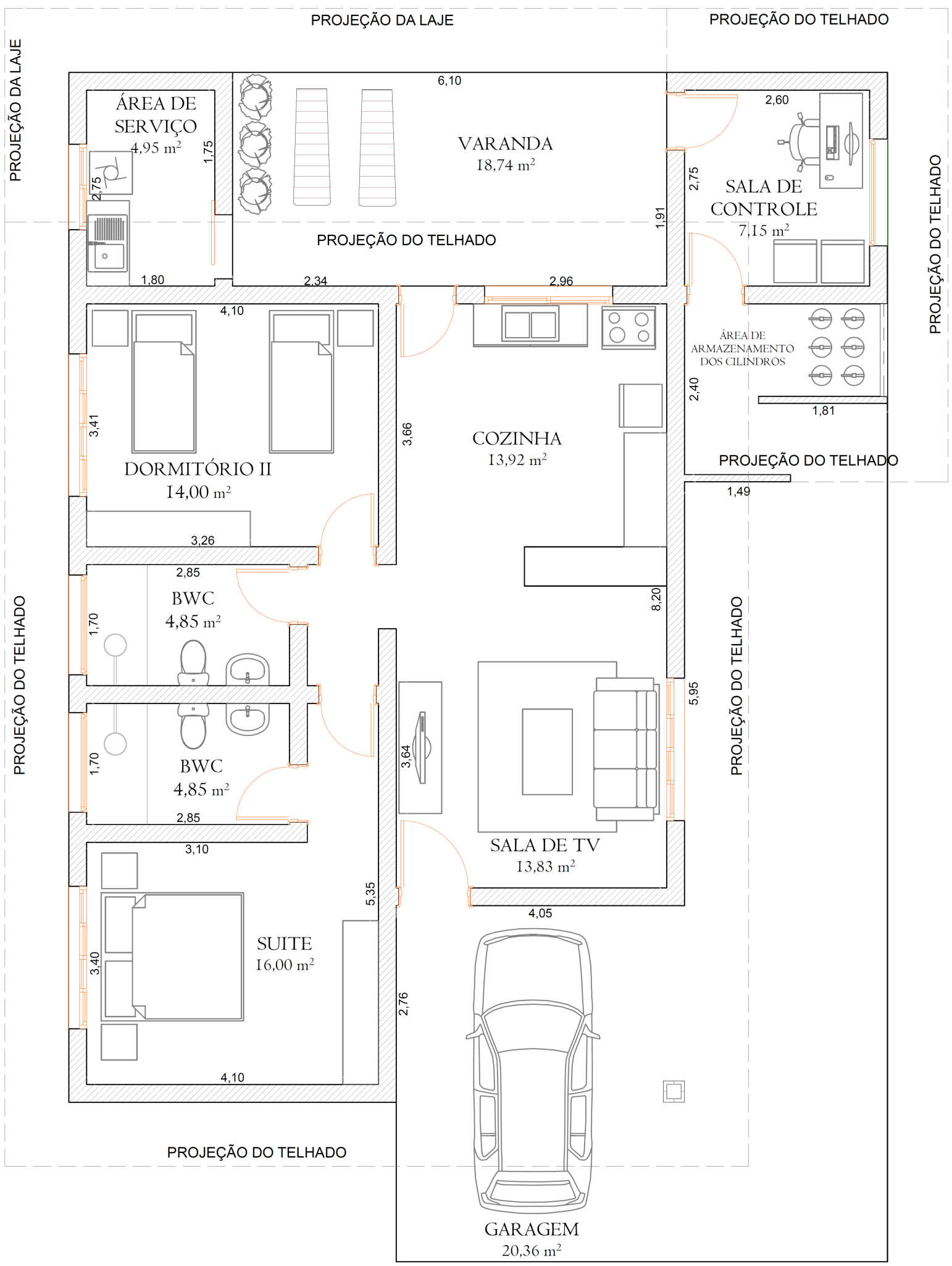

Figura 41: Planta da residência.

Fonte: Elaboração própria. 


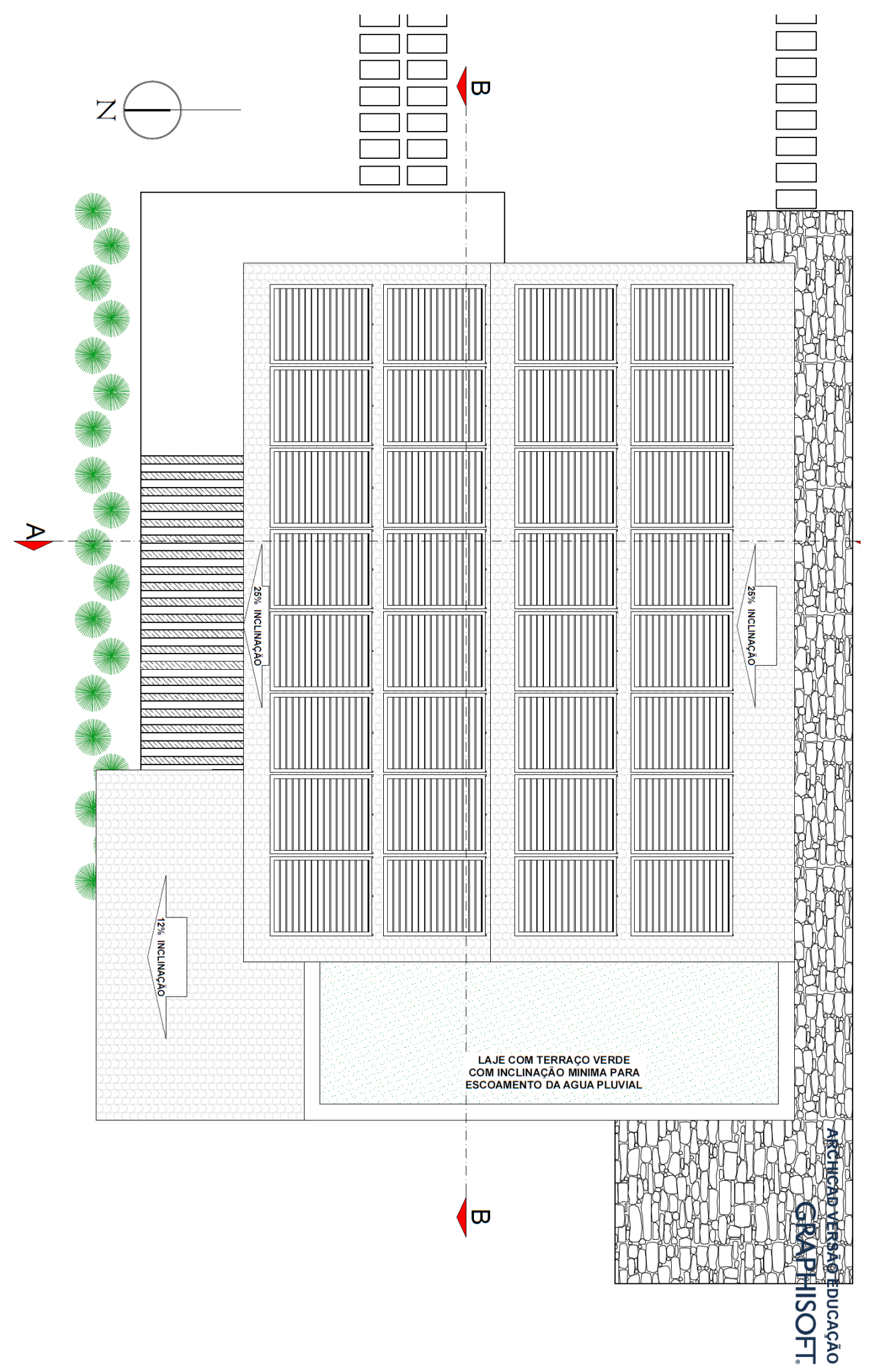

Figura 42: Planta de cobertura da residência.

Fonte: Elaboração própria. 


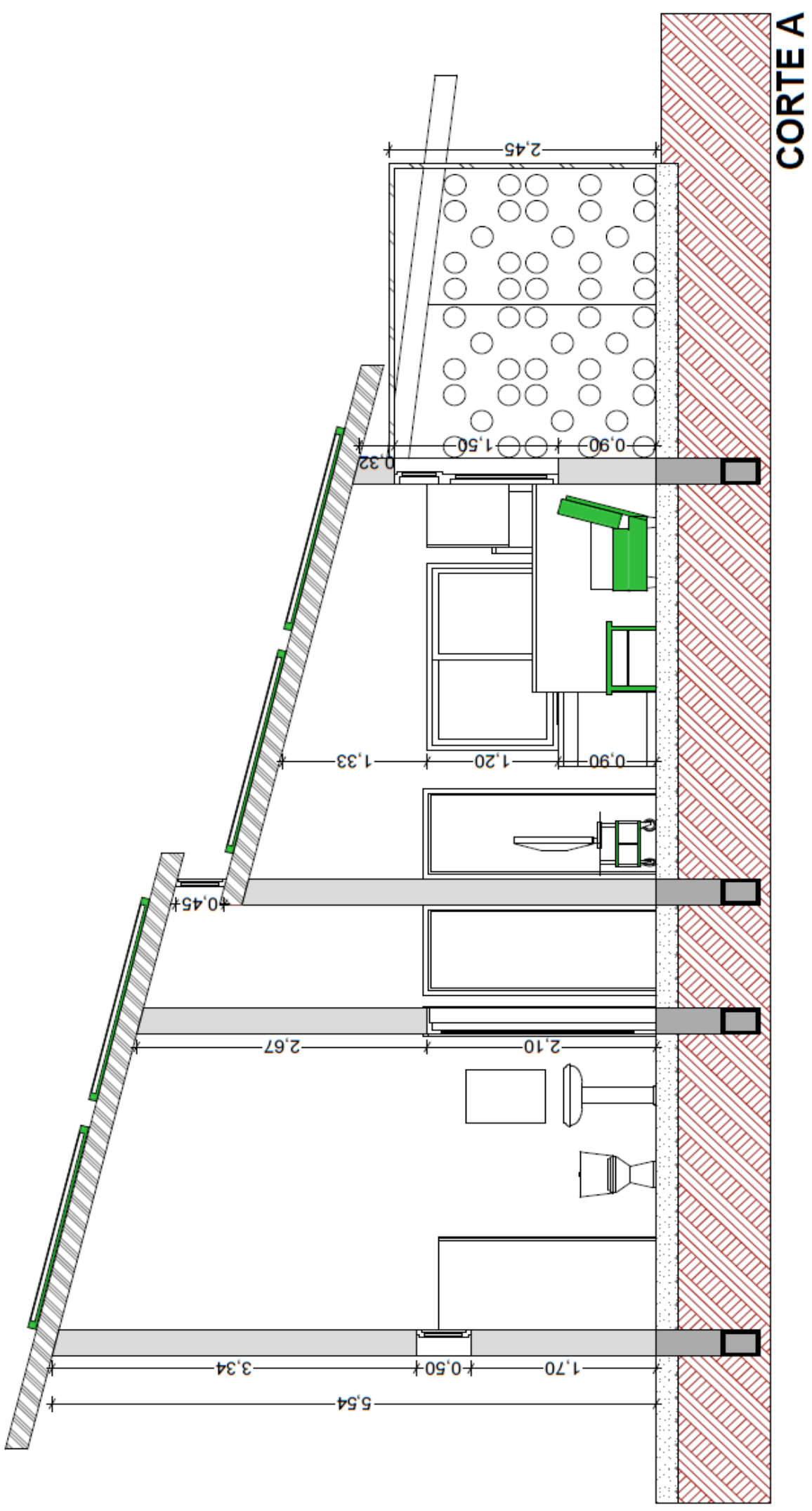

Figura 43: Corte $A$ da residência.

Fonte: Elaboração própria. 


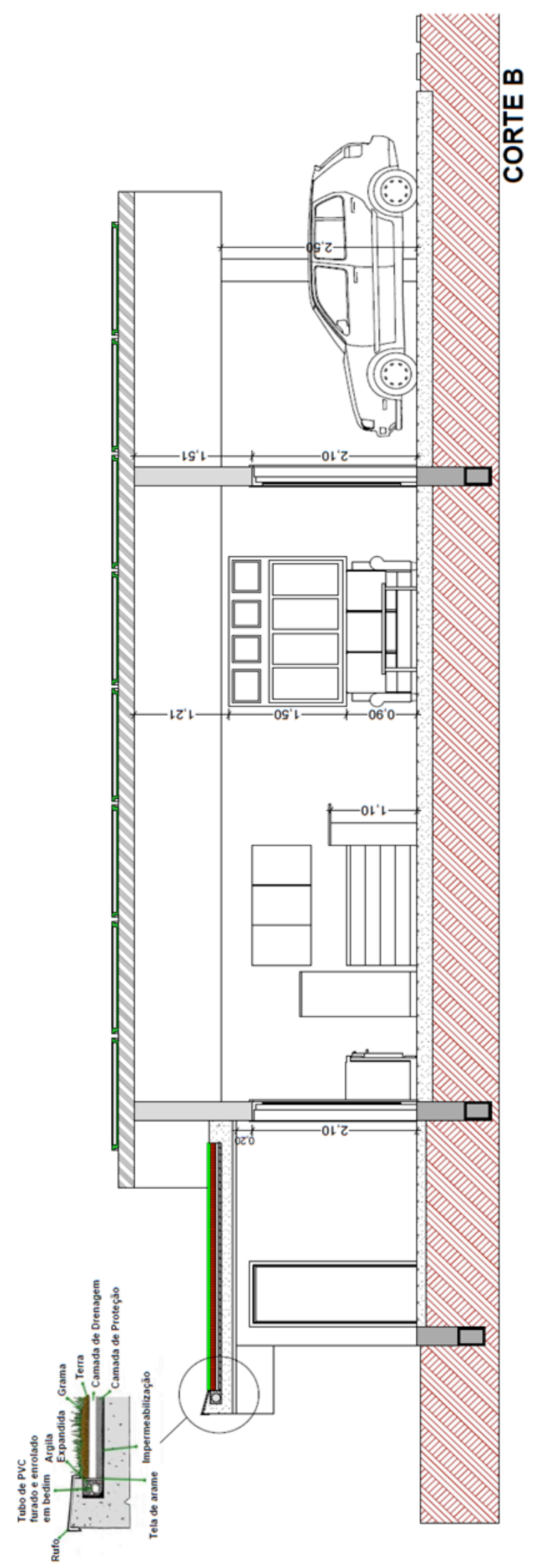

Figura 44: Corte $B$ da residência.

Fonte: Elaboração própria. 


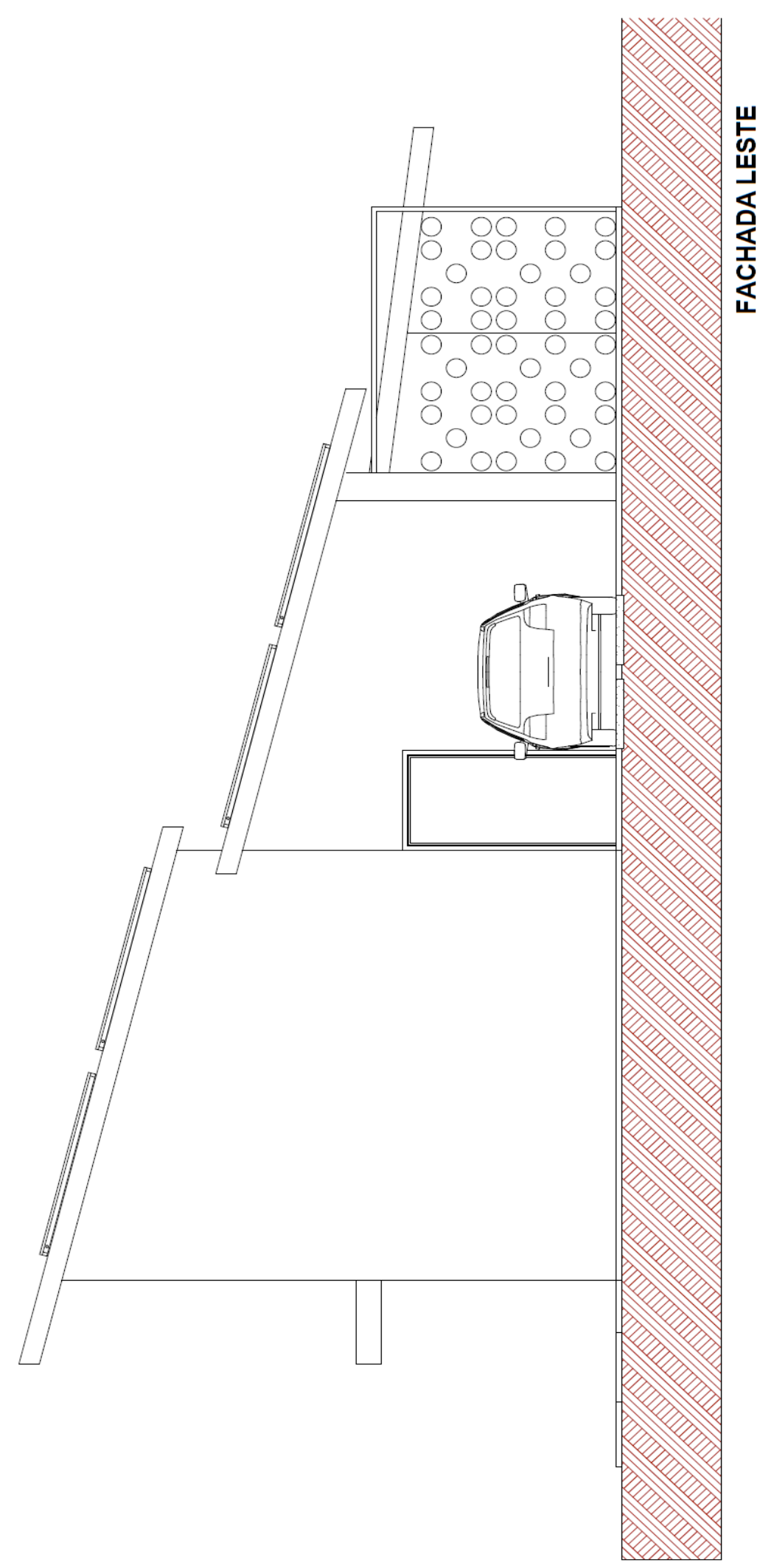

Figura 45: Fachada leste da residência.

Fonte: Elaboração própria. 


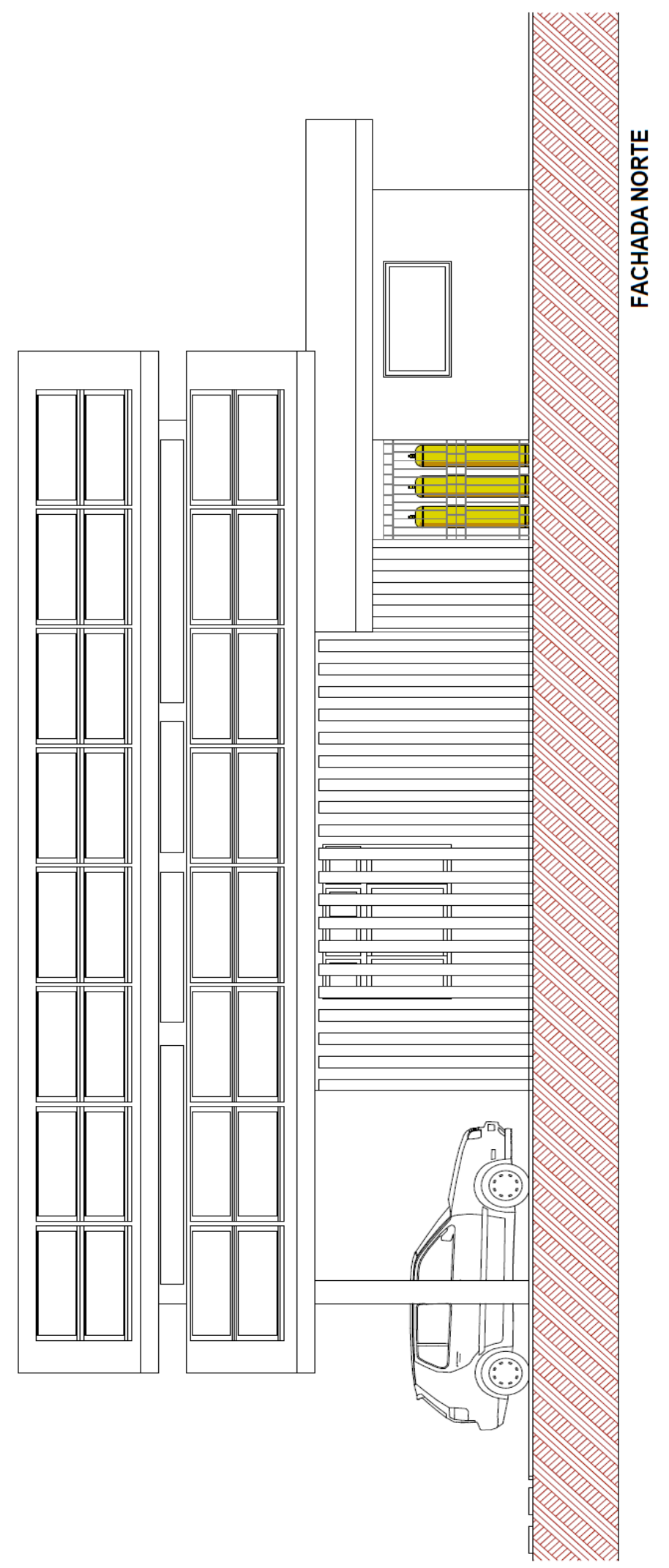

Figura 46: Fachada norte da residência.

Fonte: Elaboração própria. 


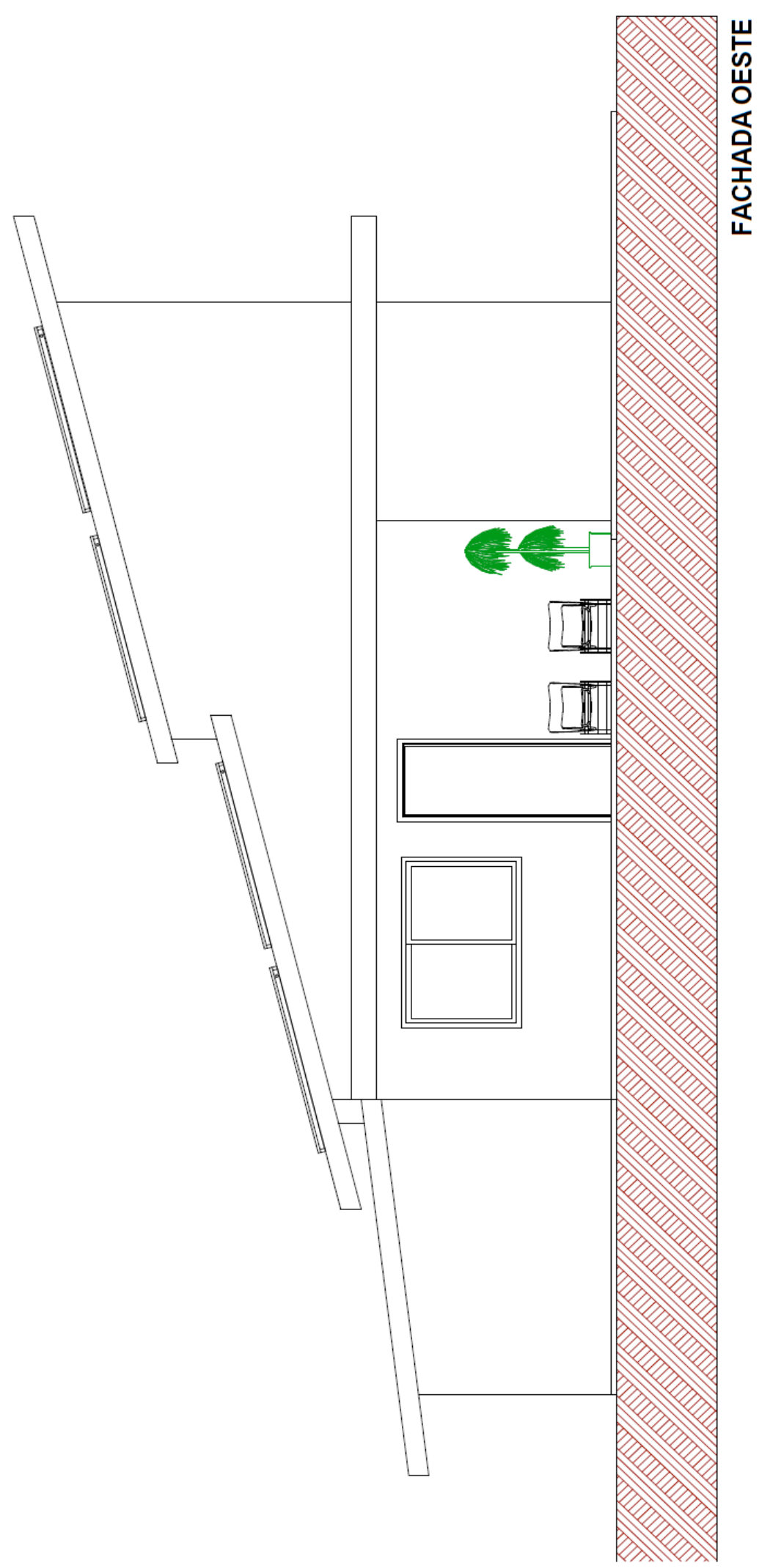

Figura 47: Fachada oeste da residência.

Fonte: Elaboração própria. 


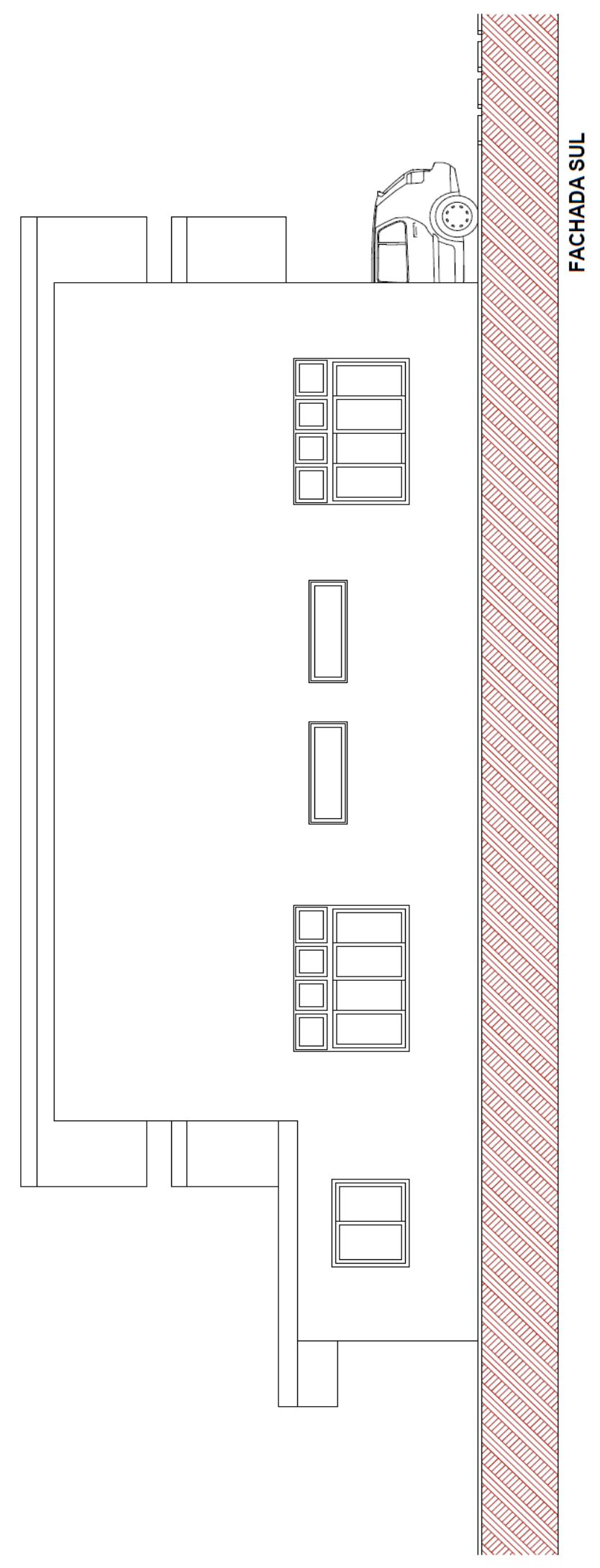

Figura 48: Fachada sul da residência.

Fonte: Elaboração própria. 


\section{em residências}

\section{Imagens $3 D$}

As figuras 49, 50, 51 e 52 representam as imagens em 3D, foram feitas em programas de modelagem tri dimensionais, e representam a residência modelo já com os ambientes necessários para receber o sistema hidrogênio solar.

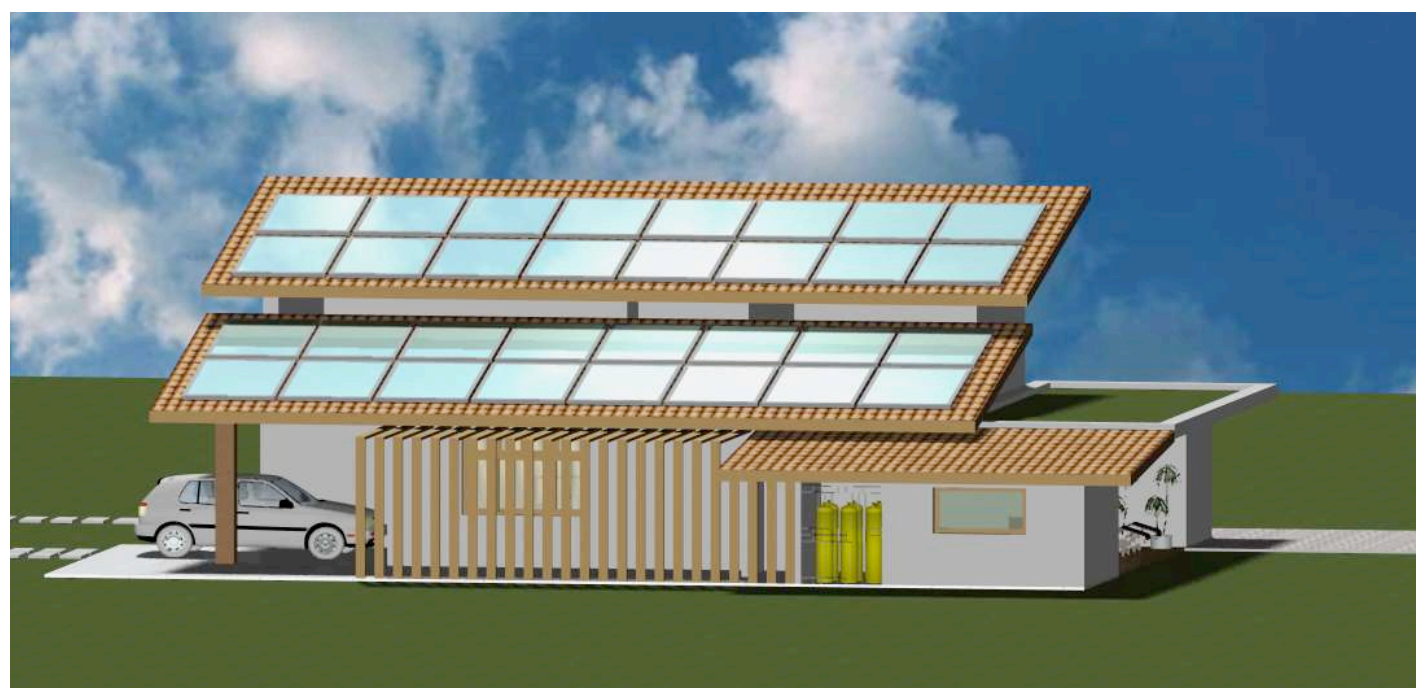

Figura 49: Perspectiva fachada norte.

Fonte: Elaboração própria.

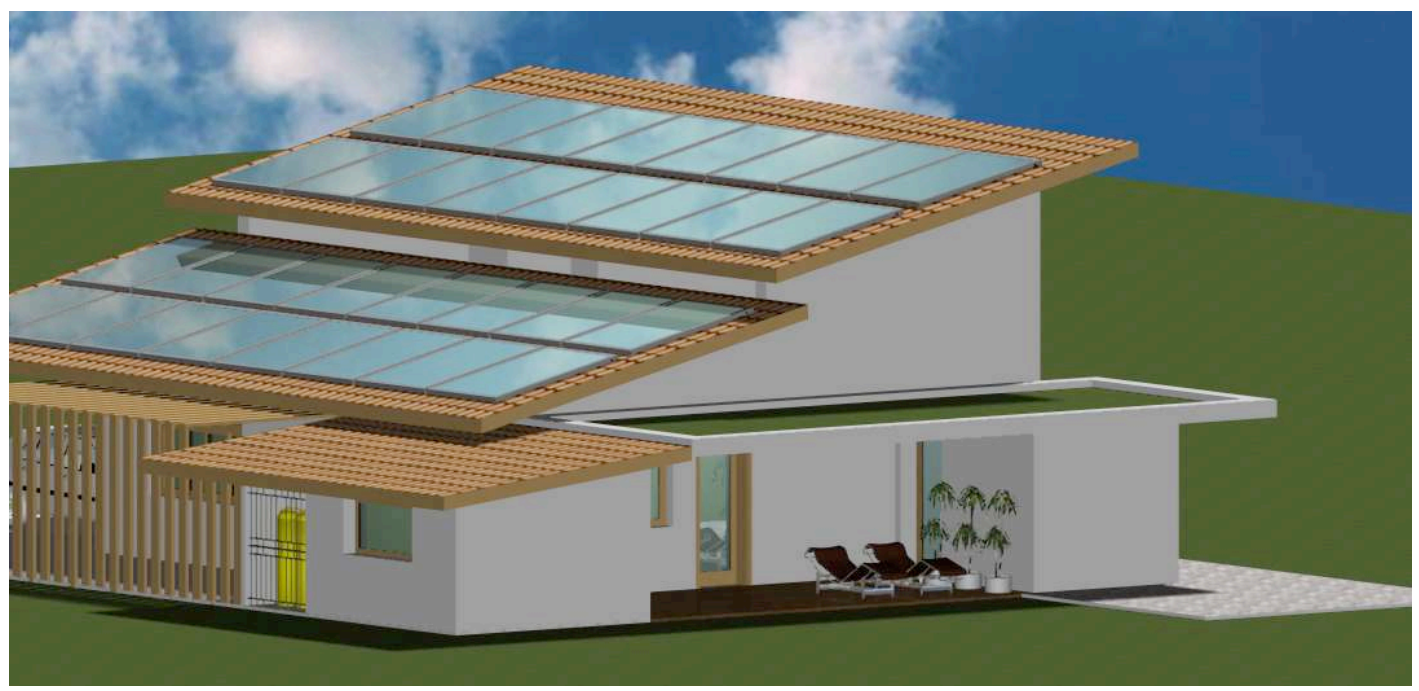

Figura 50: Perspectiva fachada oeste.

Fonte: Elaboração própria. 


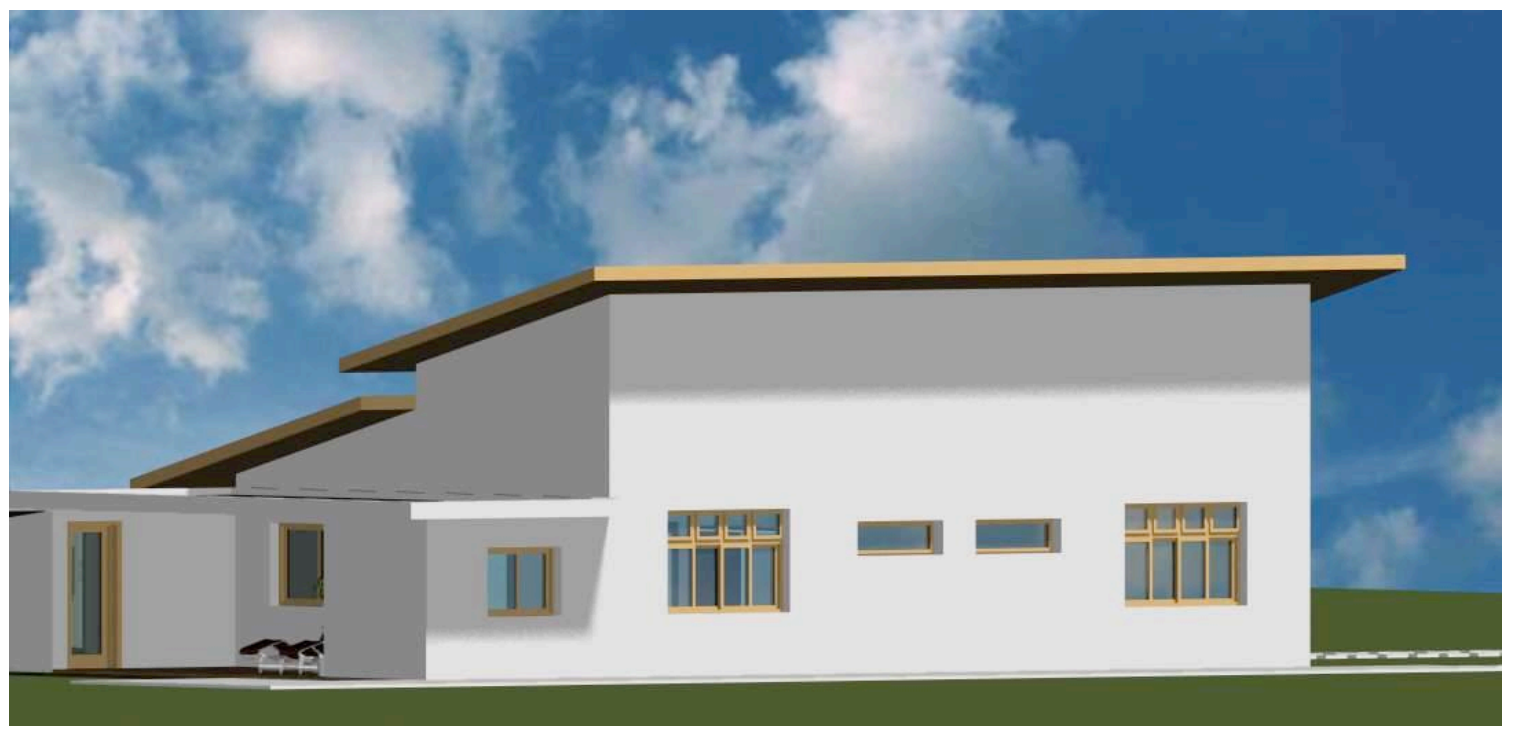

Figura 51: Perspectiva fachada sul.

Fonte: Elaboração própria.

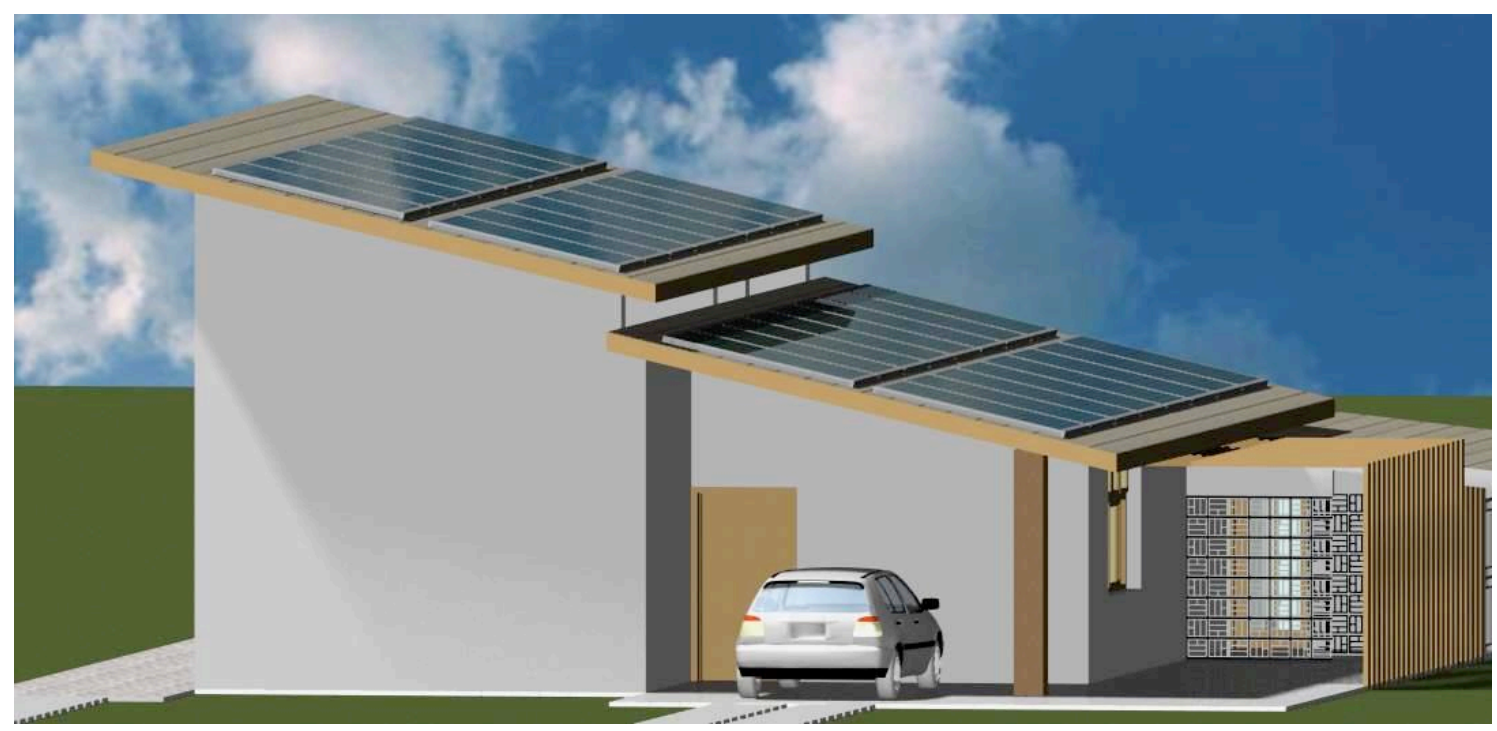

Figura 52: Perspectiva fachada leste (principal).

Fonte: Elaboração própria. 


\subsection{DIDENSIONACENGO DO SISGEDA ЋIDROGÊNIO SOLAR}

O modelo de simulação foi desenvolvido utilizando a planilha eletrônica da Microsoft Excel; nele foram introduzidas as principais características associadas aos sistemas. Para os dados de entrada foi considerada a potência do painel, estimativa de dias sem sol (30 dias no ano), horas de funcionamento, tempo de vida útil, demanda energética da casa e a eficiência no sistema.

Os principais componentes de um sistema fotovoltaico são os painéis fotovoltaicos, responsáveis pela conversão direta da radiação solar em eletricidade, na forma de corrente contínua (CC). Dependendo do tipo de aplicação, outros componentes precisam ser agregados em conjunto com os sistemas fotovoltaicos para os processos de armazenamento, regulação e controle da energia elétrica.

O sistema fotovoltaico com armazenamento de energia na forma de hidrogênio é composto principalmente pelos seguintes equipamentos:

- Painel fotovoltaico;

- Sistema de controle de potência;

- Eletrolisador;

- Reservatório de hidrogênio;

- Célula a combustível;

- Inversor de frequência.

Sistema hidrogênio solar com gerador de células a combustível interligado a rede é apresentado na figura 53 . 


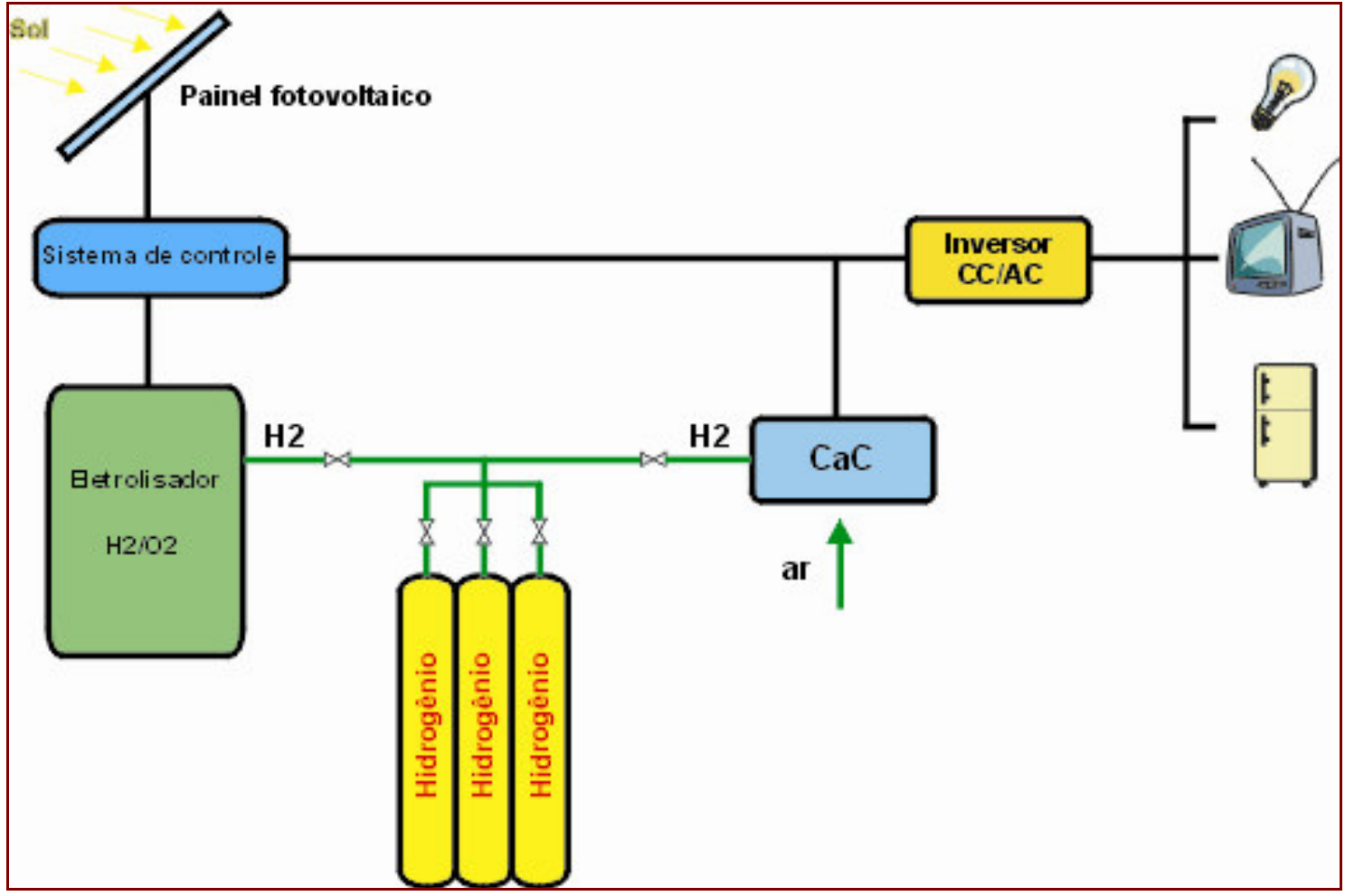

Figura 53: Sistema hidrogênio solar com gerador de células a combustível interligado a rede. Fonte: Wicac, 2012.

\section{Painel fotovoltaico}

Foram utilizados painéis fotovoltaicos da marca Kyocera, de 245 Watts de potência com eficiência de 15\%, com dimensões de 1662 × $990 \times 46$ (mm). Este módulo fotovoltaico foi certificado pelo INMETRO com nota "A", apresentando eficiência de 14,9\%. As células fotovoltaicas são protegidas por uma resistente camada de vidro temperado e a moldura em alumínio já vem com as furações para fixação. Na planilha foi adotada a eficiência do módulo fotovoltaico de acordo com a energia $\left(\mathrm{w} / \mathrm{m}^{2}\right)$ recebida, que vem a ser de $80 \%$.

Em condições ideais de insolação, este módulo solar fotovoltaico produz $245 \mathrm{~W}, 8,23 \mathrm{~A}$ e 29,8V em corrente contínua. Os módulos Kyocera Solar foram aprovados em rígidos testes de qualidade, como o teste de impacto de granizo, de resistência mecânica, de vento e torção, de resistência à salinidade e de choque térmico. A figura 54 mostra o painel fotovoltaico. 


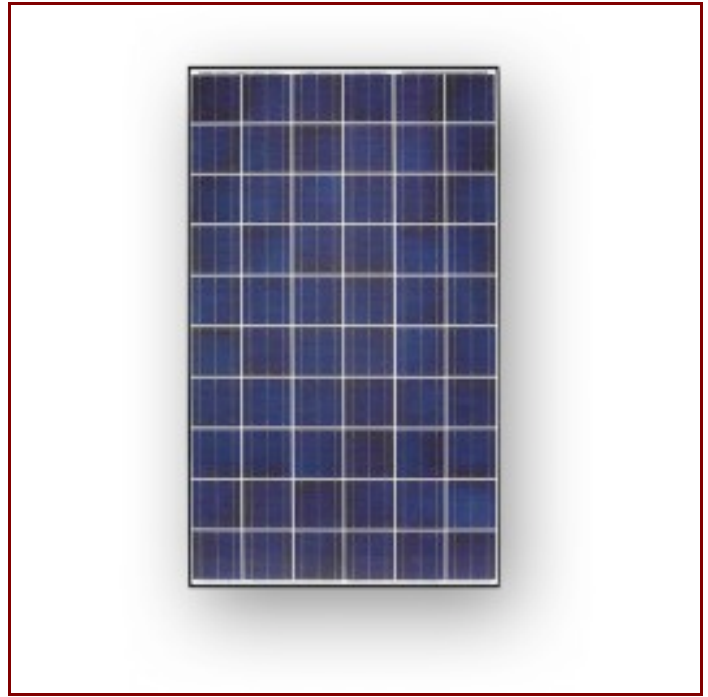

Figura 54: KD245GH-4FB - Módulo fotovoltaico multi-cristalino de alta eficiência.

Fonte: Kyocera, 2014.

\section{Eletrolisador para produção de hidrogênio}

O sistema para produção de hidrogênio eletrolítico adotado como referência é um eletrolisador bipolar PEM, o qual apresenta as características necessárias para a análise proposta pelo modelo a ser simulado. A figura 55 representa o eletrolisador internamente e a caixa de proteção.
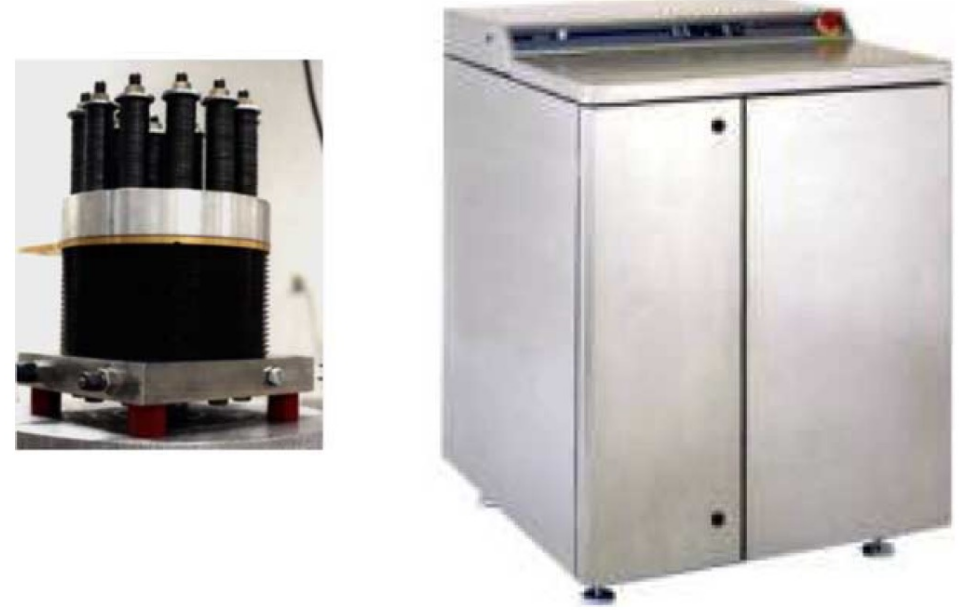

Figura 55: Eletrolisador PEM da marca HOGEN Proton Energy.

Fonte: Proton Energy Systems, 2014. 
A maioria dos eletrolisadores usados tem capacidades para produzir milhares $\mathrm{m}^{3} / \mathrm{h}$ e são baseados em eletrólito alcalino $(\mathrm{KOH})$. Outra opção é utilizar uma troca de membrana de prótons como eletrólito. Este ácido polímero perfluorossulfónico (também conhecidos como NafionTM) tem sido utilizado em eletrólise de cloro - alcalina e também em células de combustível do tipo PEM. A eletrólise PEM é um processo apenas para produzir hidrogênio em célula de combustível PEM (PROTON ENERGY, 2014).

A água é dividida em oxigênio, prótons e elétrons em um eletrodo (anodo) através da aplicação de uma Tensão CC mais elevada do que a tensão termoneutra (1.482 V). Os prótons passam através do eletrólito da membrana polimérica e no cátodo e se combinam com os elétrons para formar hidrogénio. A Passagem de prótons através da membrana é acompanhada pelo transporte de água. A figura 56 mostra o processo da eletrolise do tipo PEM.
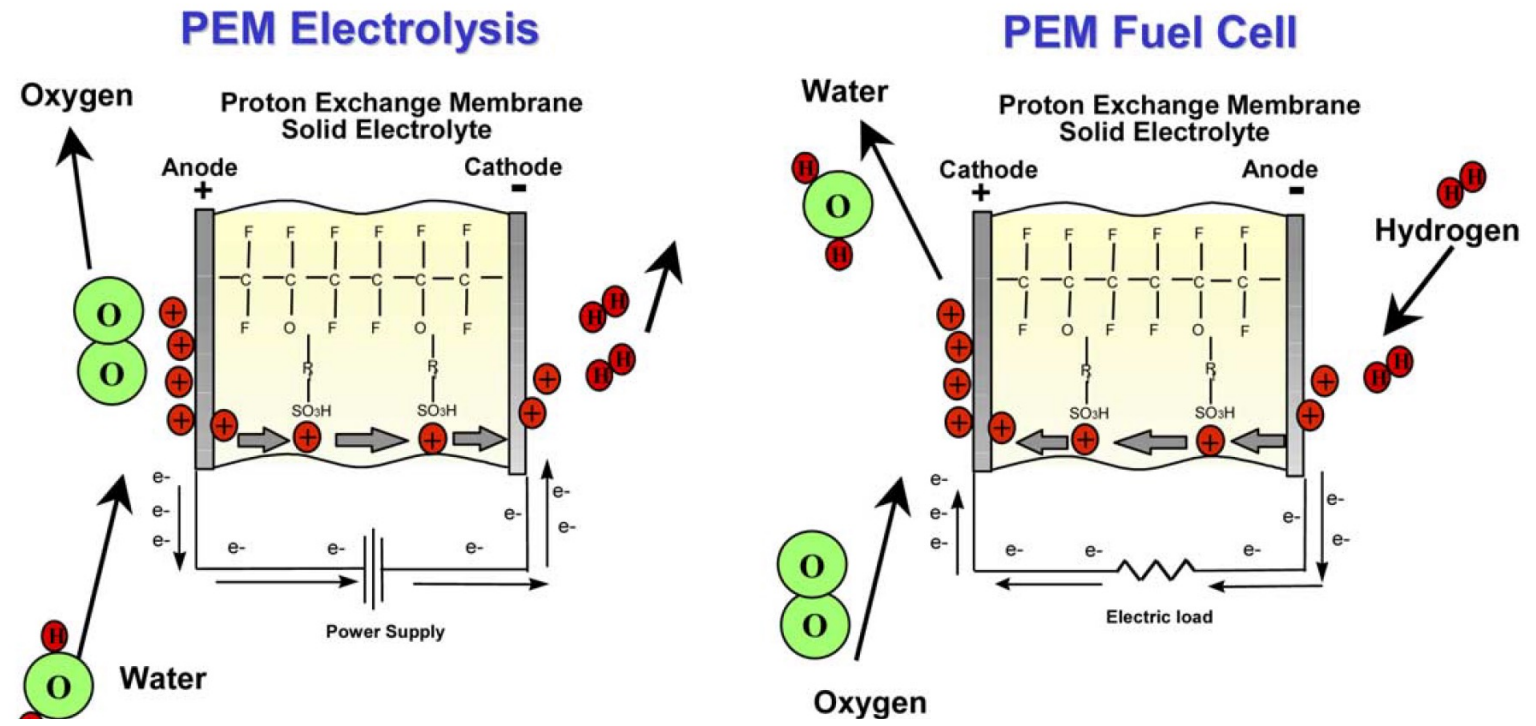

Figura 56: Representação esquemática do processo da eletrolise do tipo PEM.

Fonte: Proton energy, 2013.

A célula do eletrolisador PEM é semelhante ao de uma célula combustível PEM. Ele tem uma membrana de polímero e elétrodos porosos, campos de fluxo, coletores de corrente e placas separadoras e chapas. O princípio de funcionamento é inverter a operação de célula de combustível. No entanto, os materiais são tipicamente diferentes da célula de combustível PEM. 
Materiais de carbono, tais como suporte de catalisador, estruturas de eletrodos porosos (papel de fibra de carbono ou carbono pano) e as placas bi-polares.

As células não podem ser usadas no lado do oxigénio de um eletrolisador PEM devido à corrosão. Eletrolisadores PEM, portanto, usam principalmente componentes metálicos (estruturas porosas, campos e placas separadoras de fluxo). O catalisador é tipicamente de platina ou ligas de platina. Para alimentar as células individuais, as várias células são empilhadas, a fim de obter o resultado desejado a um preço razoável.

Além disso, no conjunto de células, um eletrolisador deve ter um regulador da fonte de alimentação / tensão, sistema de abastecimento de água, bomba de circulação de água, separadores de água e gás para o hidrogênio e (opcionalmente) de oxigênio, trocadores de calor, controles e instrumentação, incluindo os recursos de segurança. Há apenas alguns fabricantes eletrolisador PEM.

Esta composição opera autonomamente através do controle de pressão do reservatório, conectado diretamente ao eletrolisador, o qual recebe hidrogênio com pureza de $99,999 \% \mathrm{~mol} / \mathrm{mol}$. O eletrolisador tem capacidade de geração de até $1 \mathrm{~m}^{3} / \mathrm{h}$ de $\mathrm{H} 2$, pressão máxima de operação de 10 bar (1,0 MPa) e temperatura de operação programável dentro do intervalo de 30 a $60^{\circ} \mathrm{C}$.

Para o armazenamento de gases em geral, os vasos de pressão ou reservatórios devem estar de acordo com as normas de segurança NR-13, da ABNT, e possuir certificado constando que o equipamento foi submetido e aprovado no teste hidrostático, sem vazamentos ou anomalias.

A quantidade de energia disponível para o eletrolisador é uma das características relevantes para escolha do eletrolisador ideal, pois irá influenciar a sua faixa de operação. Para este sistema a energia disponível é proveniente da energia fornecida pelos painéis fotovoltaicos, após as 6 horas de uso (enquanto há sol) para o suprimento da carga demandada. Portanto, a escolha deve levar em conta esse valor. 
Através da planilha verifica-se a demanda de hidrogênio ao longo do dia durante as 6 horas que há sol, as 18 horas restantes, é outra característica importante. A faixa de pressão deve ser selecionada de acordo com as necessidades do sistema. Como neste sistema não será utilizado compressor, é interessante utilizar um eletrolisador que forneça o gás a uma pressão superior a atmosférica. Com base nos equipamentos comerciais que se tem conhecimento, um valor considerado razoável, neste caso, é 10 bar. Pressões menores implicarão em reservatórios maiores. Caso fosse utilizado um compressor, o eletrolisador poderia operar e fornecer o gás à pressão atmosférica, mas, como desvantagem, haveria um maior consumo de energia para a compressão e mais um componente no sistema que necessitaria de manutenção.

\section{Célula a combustível de $5 \mathrm{k} W$ de potência}

A célula a combustível adotada como referência para a reconversão do hidrogênio em energia elétrica é da empresa UNITECH a qual apresenta as características necessárias para a análise proposta pelo modelo teórico a ser simulado. Este modelo foi escolhido devido a Empresa UNITECH dispor de vários equipamentos desse tipo e conhecer os parâmetros de operação, tais como o consumo de hidrogênio e energia elétrica produzida. A célula fornece 5 kW como máxima potência de saída, possui uma faixa de tensão ajustável de 24,9 a 27,5 VDC, utiliza hidrogênio como combustível com um grau de pureza $99,95 \% \mathrm{~mol} / \mathrm{mol}$ operando a uma pressão de 2 bar (0,2 MPa), apresentando um consumo de hidrogênio de $0,75 \mathrm{~m} 3 / \mathrm{kWh}$, podendo trabalhar na faixa de temperatura de -40 a $50^{\circ} \mathrm{C}$.

A célula a combustível será utilizada durante 24 horas por dia, isso quer dizer que, quando não há energia do painel solar ou, na falta total de luz solar, ela será abastecida por hidrogênio armazenado para suprir toda a demanda energética do sistema. Por esse motivo, a sua potência deverá ser equivalente ao pico de consumo ao longo de 24 horas, o que poderá ser verificado na planilha de cálculo desenvolvida. 
O pico de consumo fornecido pelo modelo indica uma potência de $5 \mathrm{~kW}$, logo a célula a combustível para este sistema deverá estar apta a operar nessa faixa de potência. Os mesmos argumentos são válidos para dimensionamento do inversor de frequência. A figura 57 mostra a célula utilizada no sistema.

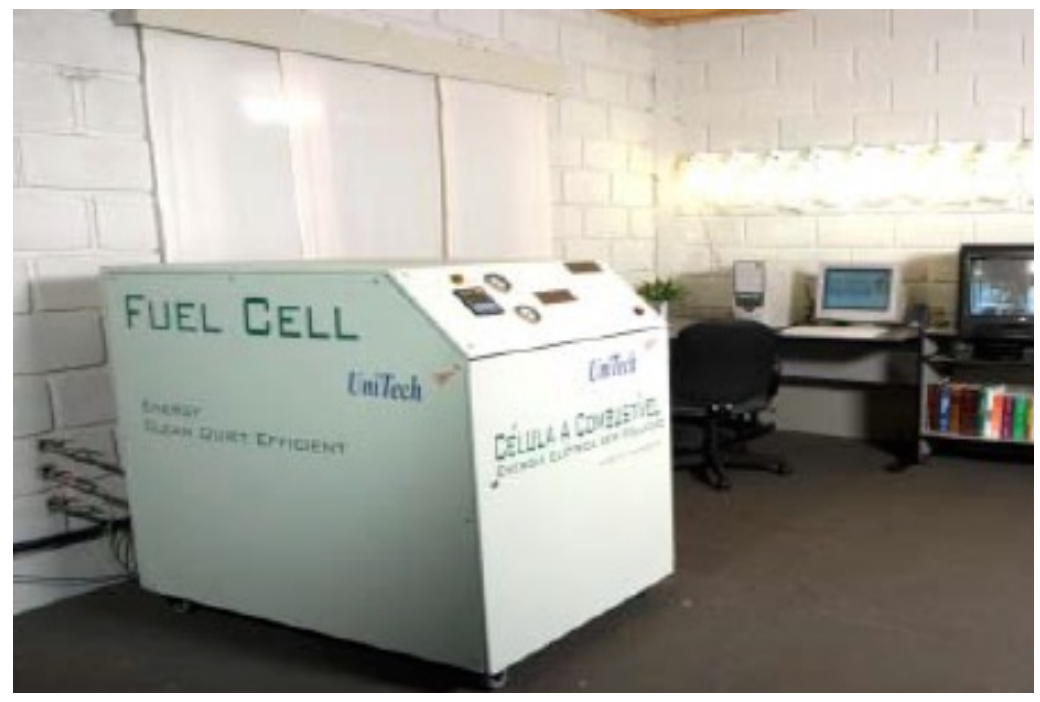

Figura 57: Célula a combustível de 5 kW.

Fonte: UNITECH, 2012.

\section{Sistema eletrônico de controle}

O sistema fotovoltaico com armazenamento de hidrogênio, no entanto, é um sistema pouco complexo do ponto de vista operacional, que necessita de um equipamento específico para realizar o controle e operação de todo o processo. Os inversores devem integrar ambos os sistemas e apresentarem características técnicas similares.

O sistema operacional de uma célula consiste em todos os dispositivos de acionamento e controle, bem como de segurança, que permite uma operação das células como as especificações, dependendo da sua aplicação.

Os sistemas operacionais para aplicações móveis são mais sofisticados e precisam ser muito mais rápidos que os sistemas operacionais para aplicações estacionárias, devido à própria 
dinâmica dos automóveis. Este trabalho se limita a descrever as funções e características de sistemas operacionais para instalações estacionárias.

Num curto intervalo de tempo (da ordem de minutos), o sistema abrange todos os parâmetros de operação de todas as partes da instalação, analisa e gerencia a instalação química segundo a solicitação de potência elétrica e reconhece, em tempo, perturbações e falhas nos parâmetros de processo. O sistema dispara, primeiramente, um alarme, quando da ocorrência de falhas e, em seguida, procede automaticamente o desligamento da célula de maneira ordenada e suave. O sistema também pode avisar sobre mudanças de solicitação de potência, se programado pelo operador, e efetuar a mudança. Dados importantes são, atualmente, armazenados por cerca de 24 horas e podem ser transmitidos a outro sistema de dados, facilitando um tardio diagnóstico ou busca de falha. Uma importante premissa para a utilização de instalações de células a combustível para aplicações residenciais é a utilização de um sistema operacional confiável e de baixo preço (LINARDI; ARICÓ, 2001).

O dispositivo eletrônico deve respeitar as condições de operação dos equipamentos especificadas pelos fabricantes, conforme a descrição a seguir.

- O eletrolisador inicia seu funcionamento quando a energia elétrica disponível para sua operação for maior que a energia mínima requerida;

- O eletrolisador tem seu funcionamento interrompido quando o reservatório de hidrogênio atingir sua pressão máxima ou, o eletrolisador opera com a intenção de atenuar as oscilações da rede, mas neste caso, o hidrogênio produzido seria descartado;

- Para iniciar seu funcionamento a célula a combustível necessita que a pressão no reservatório de hidrogênio seja maior do que a pressão de operação mínima exigida por ela;

- A célula a combustível tem seu funcionamento interrompido quando a condição anterior não for atendida ou a partir do instante em que o fornecimento de energia fotovoltaica seja igual ou superior à demanda requerida. A figura 58 mostra o software que controla automaticamente as funções do sistema. 


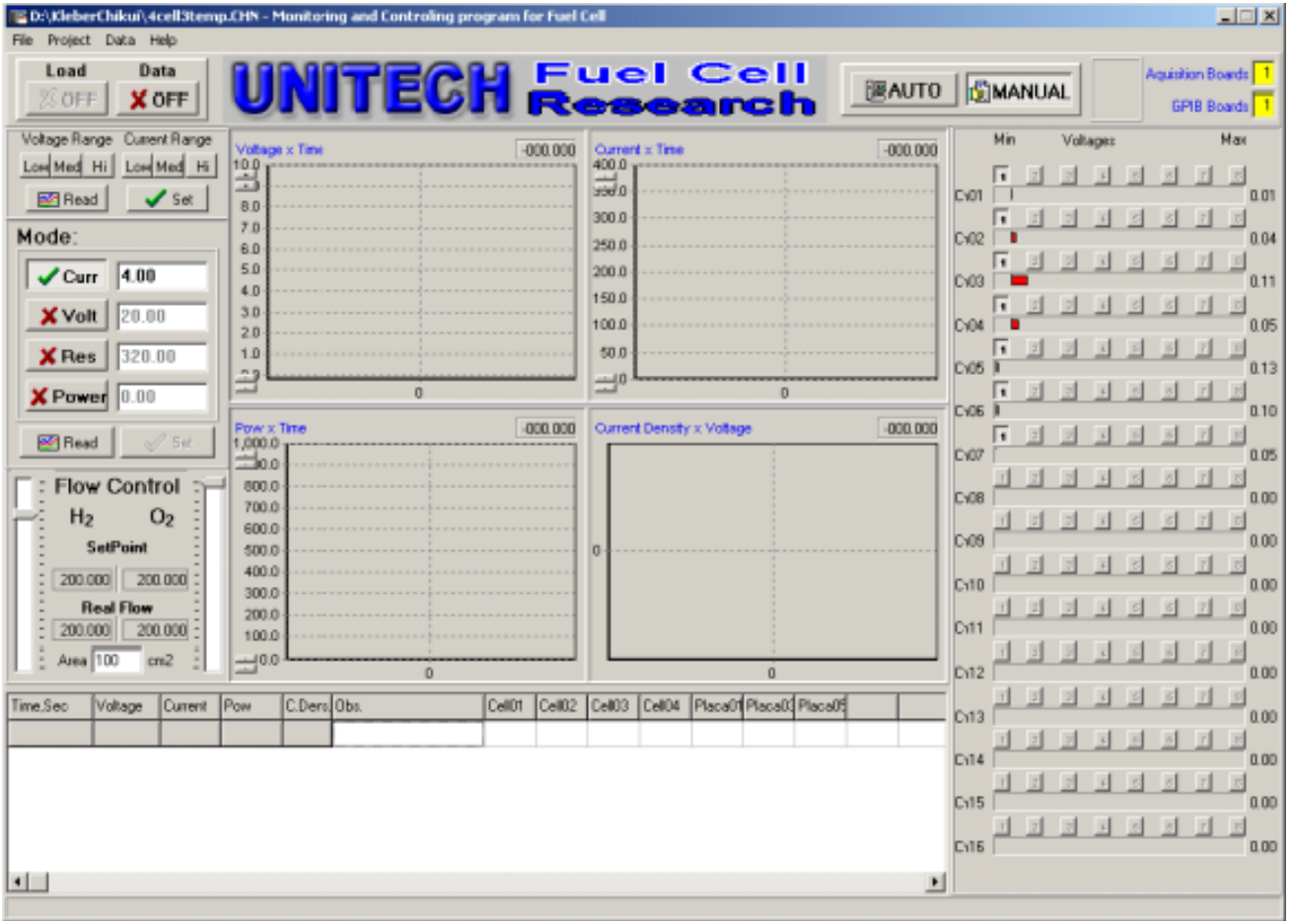

Figura 58: Software de controle para sistema de célula a combustível.

Fonte: UNITECH, 2011.

\section{Perfil da Potência}

A potência requerida pelo modelo residencial foi de $5 \mathrm{~kW}$ levando em consideração todos os eletrodomésticos ligados ao mesmo tempo. Não foi somado a potência dos chuveiros, pois estes serão atendidos pela água quente utilizada da cogeração de energia da $\mathrm{CaC}$, ou até por um sistema auxiliar de energia solar fototérmica com os componentes básicos (coletores, tanques de armazenamento, controladores e misturadores).

A CPFL (Companhia de Força e Luz ) dispõe para as edificações urbanas uma média de 15 a $17 \mathrm{~kW}$, para atender a demanda energética, considerando todos equipamentos ligados ao mesmo tempo, inclusive os chuveiros elétricos usuais (ANEEL, 2014). 
Características gerais dos componentes utilizados no sistema hidrogênio fotovoltaico

No quadro 28 são demonstrados todos os componentes utilizados para o estudo do sistema hidrogênio solar movido a célula combustível.

\begin{tabular}{|c|c|}
\hline \multicolumn{2}{|c|}{ PAINÉIS FOTOVOLTAICOS } \\
\hline Modelo & Kyocera $245 \mathrm{~W}$ \\
\hline Tecnologia & policristalino \\
\hline Área $\mathrm{m}^{2}$ & 1,64 \\
\hline Peso (kg) & 21 \\
\hline \multicolumn{2}{|c|}{ ELETROLISADOR } \\
\hline Modelo & PEM Proton energy \\
\hline Pressão (bar) & 10 \\
\hline Quantidade de $\mathrm{H} 2$ produzida $\left(\mathrm{m}^{3}\right)$ & 0,75 \\
\hline Potência $(\mathrm{kW})$ & 5,4 \\
\hline \multicolumn{2}{|c|}{ RESERVATÓRIO DE H2 - ESTADO GASOSO } \\
\hline Cilindros & $\begin{array}{c}\text { Fina camada de aço ou alumínio envolto } \\
\text { totalmente por outros compostos como fibras } \\
\text { de carbono. }\end{array}$ \\
\hline Volume por cilindro $\left(\mathrm{m}^{3}\right)$ & 10 \\
\hline Pressão (bar) & 2 \\
\hline Potência (kW) & 5,4 \\
\hline \multicolumn{2}{|c|}{ CÉLULA A COMBUSTÍVEL PEM } \\
\hline Potência (w) & 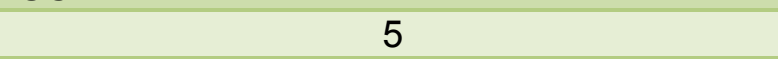 \\
\hline Consumo de $\mathrm{H} 2\left(\mathrm{~m}^{3} / \mathrm{kWh}\right)$ & 0,75 \\
\hline Pressão de operação (bar) & 2 \\
\hline
\end{tabular}

Quadro 28: Componentes utilizados no sistema de 5kW.

Fonte: Elaboração própria. 


\subsection{ANÁLISE DO PROCESSO PROJEGUAL UGILIZANDO O SISGECA DE CÉLULA A COMBUSGÍVEL DOVIDA A ЋIDROGẾNIO SOLAR}

A figura a seguir mostra a planta da residência já com as alterações necessárias para a implantação do sistema solar hidrogênio movido a célula a combustível. O partido do projeto levou em consideração o clima, com a aplicação da carta solar (para escolha da disposição dos cômodos e suas funcionalidades) e da carta bioclimática, que se refere a NBR 15220, para escolha das estratégias bioclimáticas, tal qual, tipo de parede, tipo de cobertura e dimensões das aberturas utilizadas. Na figura ainda é possível identificar a planta da residência com os espaços previstos para a implantação do sistema hidrogênio solar célula a combustível.

Nota-se que a disposição dos cômodos em planta não foi alterada pela implantação do sistema. A residência continua praticamente com a mesma dimensão, forma e disposição em relação a qualquer residência que seja alimentada por uma fonte de energia convencional.

A alteração é a introdução de um novo ambiente que servirá como Sala de controle. É nesse ambiente que ficará instalado o eletrisador, a célula a combustível e um computador para controle do sistema. O ambiente tem dimensões de 2,65m x 2,70m, uma área de 7,15 $\mathrm{m}^{2}$, com janela e portas de acesso e necessita ficar próximo ao espaço onde se encontram os cilindros de armazenamento de hidrogênio. Os tubos de conexão entre o eletrolisador, os cilindros e a célula a combustível ficam protegidos das intempéries.

Outra alteração é quanto ao espaço de armazenagem dos cilindros que foi planejado de acordo com as normas. Um espaço aberto, ventilado, fechado com grades para acesso, com dimensões mínimas para a estocagem de 6 cilindros de hidrogênio com cobertura de laje de cimento. Na figura 59 os novos ambientes necessários para a locação do novo sistema de energia eletrica estão indicados com uma seta vermelha. 


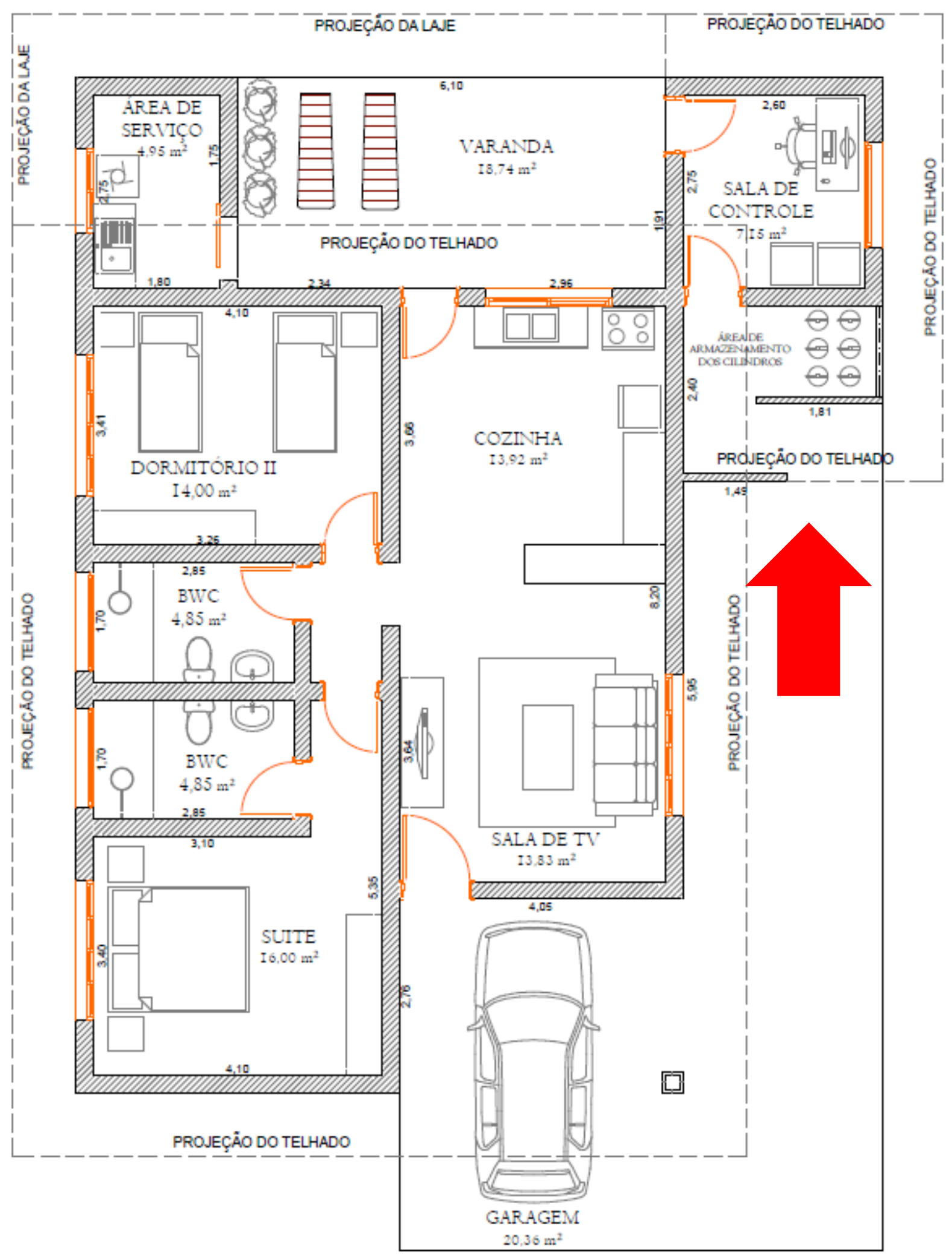

Figura 59: Planta da residência.

Fonte: Elaboração própria. 


\section{em residências}

Pode se fazer uma analogia da casa de gás de cozinha (GLP - Gás Liquefeito de Petróleo) com a casa de armazenamento dos gases necessários para o sistema hidrogênio solar. Na elaboração do projeto de uma casa é importante saber onde os botijões de gás irão ficar. Este local deverá fornecer segurança aos moradores e ao imóvel e permitir um funcionamento adequado das instalações, sendo de fácil acesso para manutenções. Geralmente nas residências, onde são utilizados botijões de GLP de $13 \mathrm{~kg}$ ou de $45 \mathrm{~kg}$, a casa de gás é construída em alvenaria, como uma "casinha", com alguma ventilação, para que em caso de vazamento, o perigo de incêndio seja reduzido. Apesar de não existirem leis federais sobre casas de gás, existem normas técnicas para regular as instalações, válvulas e mecanismos de segurança. Estas normas são obrigatórias em residências multifamiliares, obras comerciais e industriais. A figura 60 mostra a casa de gás.
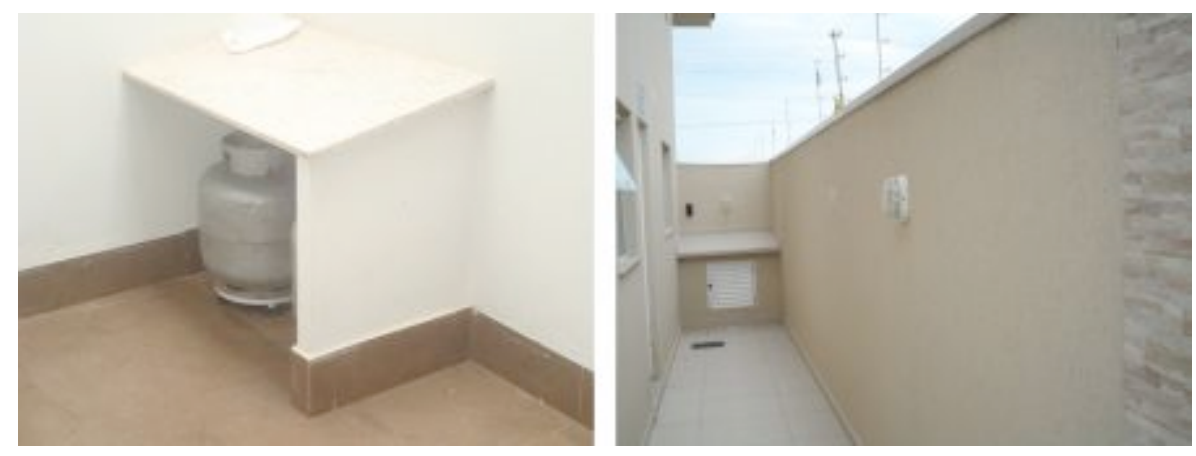

Figura 60: Casa de gás GLP.

Fonte: Arquivo pessoal.

A figura 61 representa o projeto em maquete eletrônica, já considerando os espaços necessários para introdução do sistema. O ambiente que abriga a célula a combustível e o eletrolisador se encontra na fachada norte, próximo aos painéis fotovoltaicos. A cobertura do ambiente e do espaço de armazenamento dos cilindros é de telha cerâmica (assim como todo restante da casa) com forro de laje. 


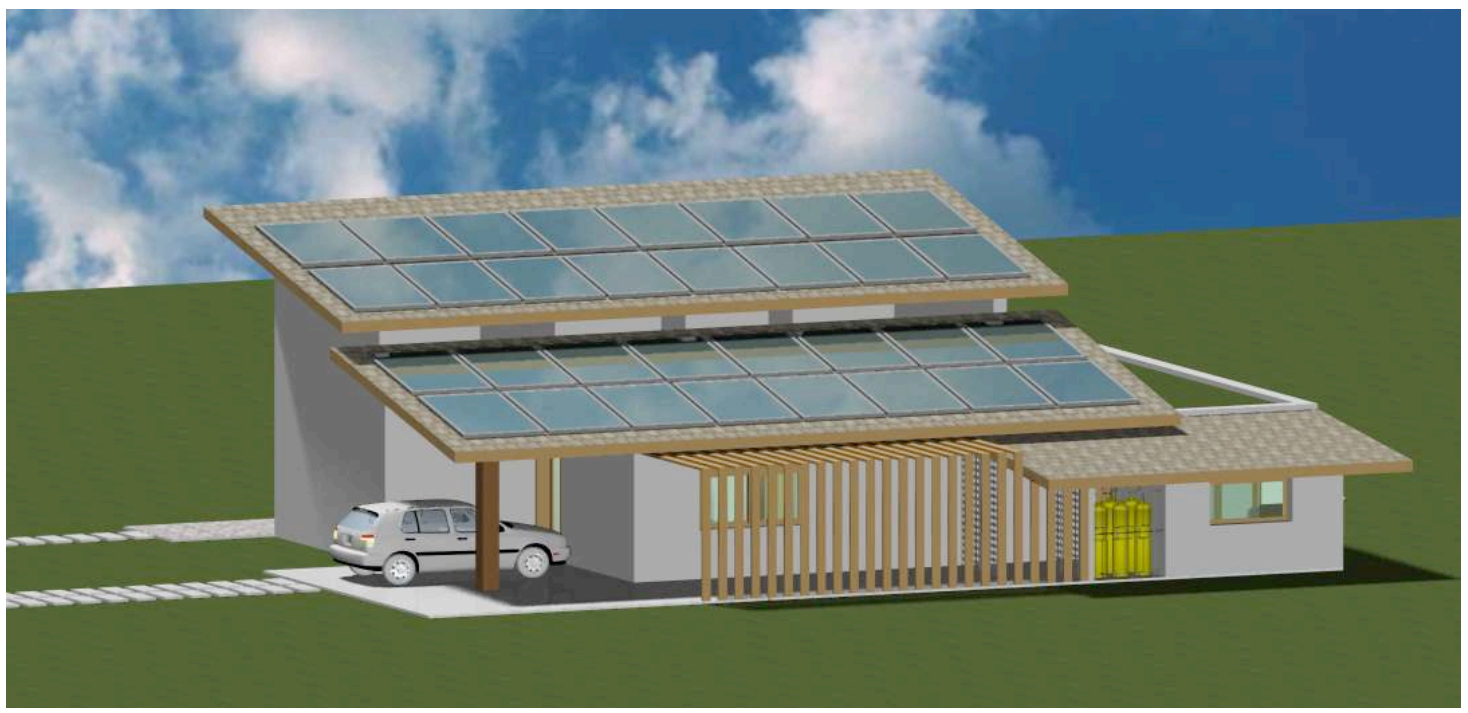

Figura 61: Perspectiva da residência.

Fonte: Elaboração própria.

As figuras 62 e 63 representam o ambiente onde ficam a célula a combustível, o eletrolisador e um computador que controla o sistema automaticamente. O espaço ao lado é aberto, arejado de acordo com as normas de segurança de armazenamento de cilindros contra incêndio. Há uma grade de proteção e um fechamento com elementos vazados que liga esse espaço a varanda lateral norte da casa. A entrada da "casa de máquinas" é pela varanda da fachada oeste, assim como a entrada da lavanderia. 


\section{em residências}

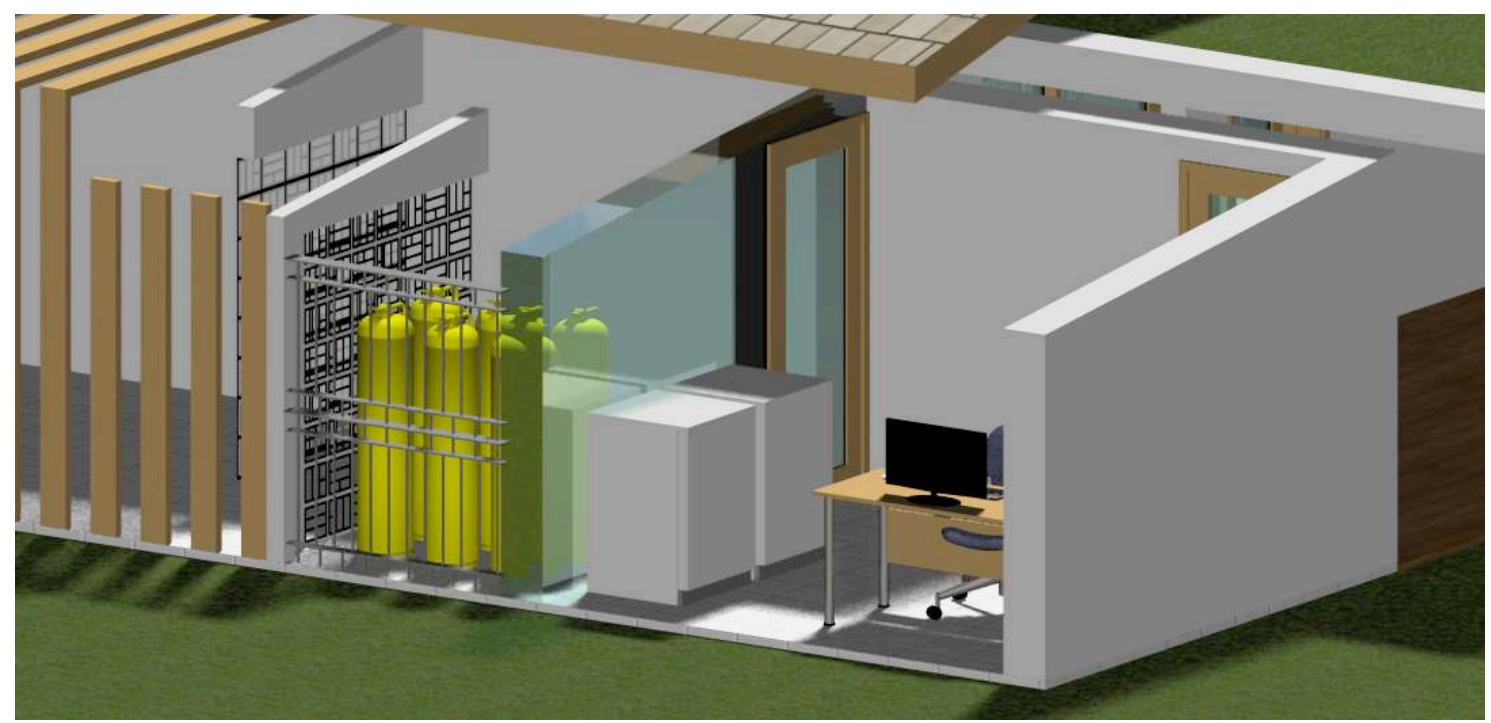

Figura 62: Perspectiva da casa de maquinas.

Fonte: Elaboração própria.

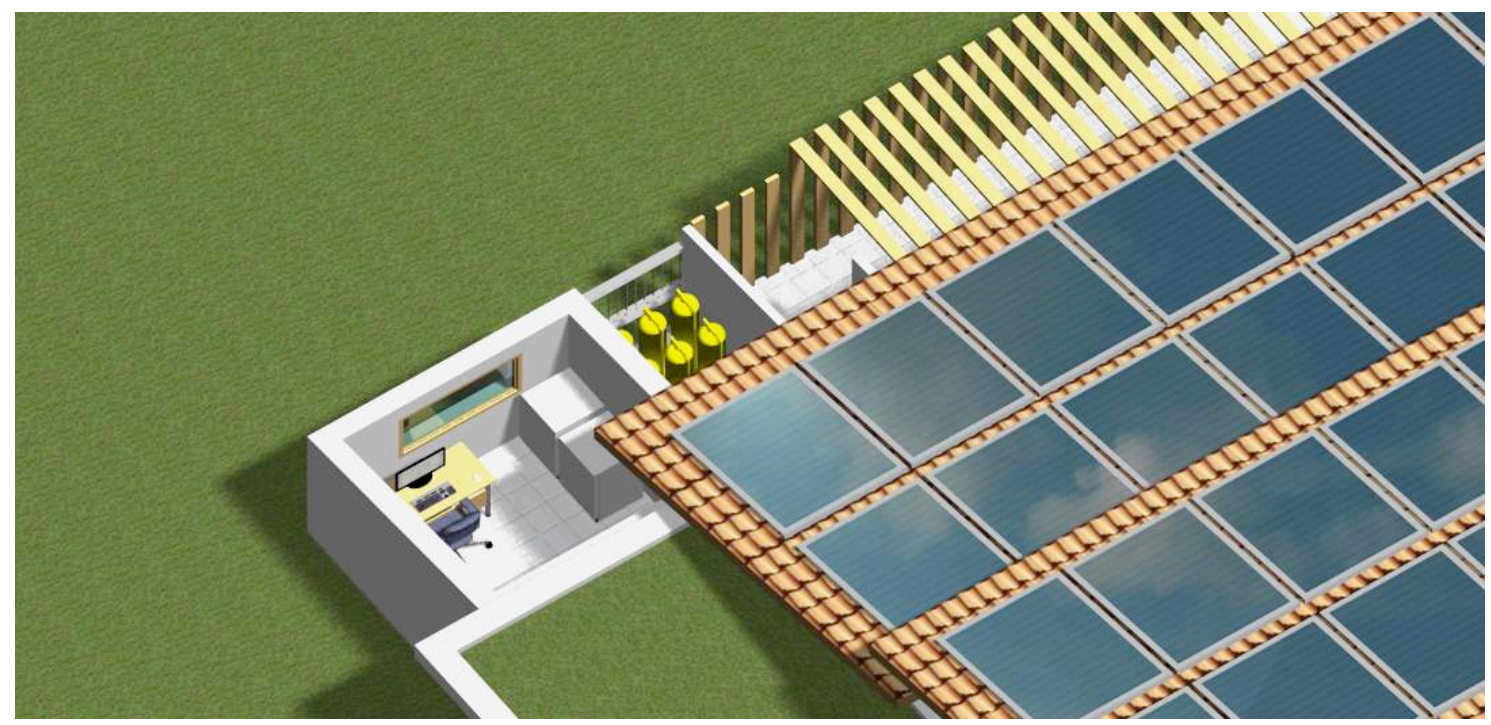

Figura 63: Vista de cima da casa de máquinas.

Fonte: Elaboração própria.

A figura 64 mostra as ligações do sistema sendo primeiramente abastecido pela energia solar proveniente dos painéis fotovoltaicos que ligam até o eletrolisador para realizar a eletrólise da água produzindo hidrogênio para ser estocado nos cilindros do lado de fora da casa de máquinas. Na sequência o hidrogênio dos cilindros abastece a célula a combustível que gera a energia elétrica necessária para atender a necessidade da residência. 


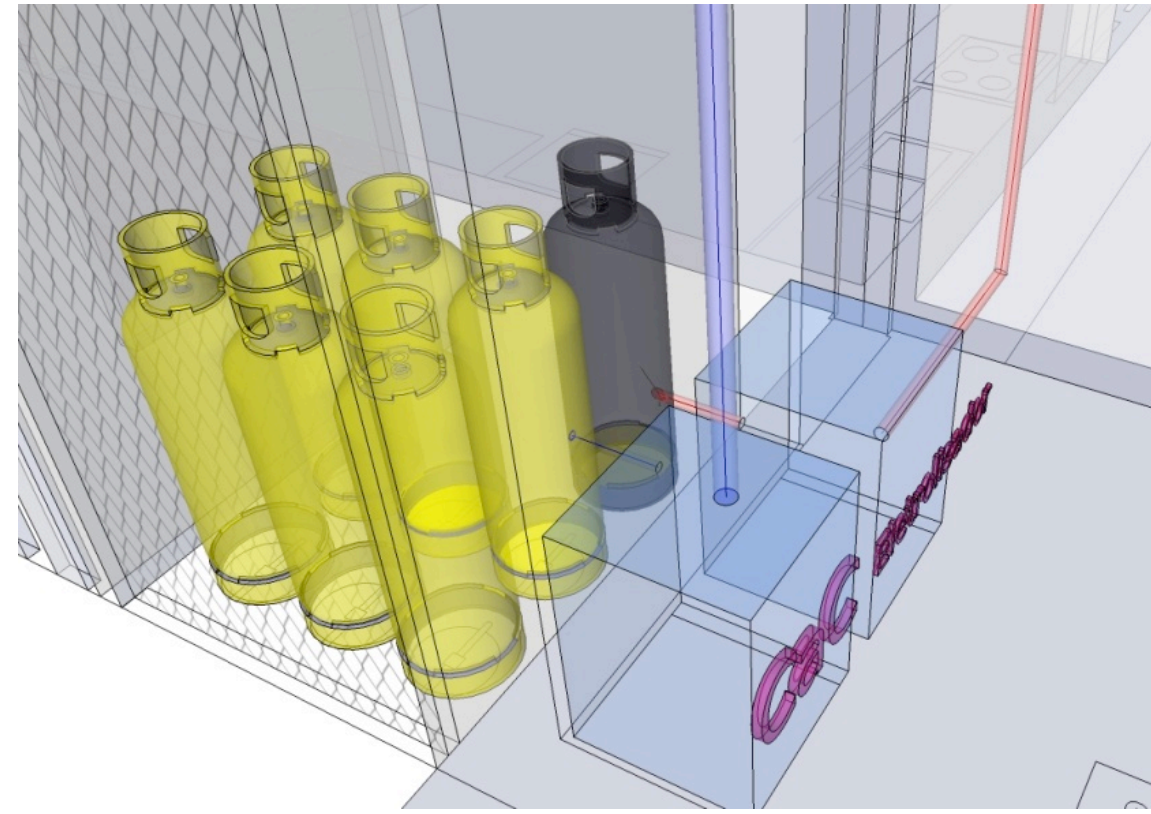

Figura 64: Vista da casa de máquinas com as ligações entre os componentes do sistema. Fonte: Elaboração própria.

A figura 65 mostra o modelo principal com uma célula de $5 \mathrm{~kW}$, um eletrolisador PEM e 6 cilindros de hidrogênio. A potência requerida pelo modelo residencial foi de $5 \mathrm{~kW}$ com a estimativa de uma demanda mensal de $450 \mathrm{kWh}$, levando em consideração a demanda energética em kWh/dia, seguindo a estimativa padrão das residências brasileiras através da curva de demanda da Eletrobrás. Os eletrodomésticos foram estimados de acordo com o PROCEL e com a soma das potências chegou a um resultado de $5 \mathrm{~W}$. A figura 64 mostra a curva de carga diária media. 


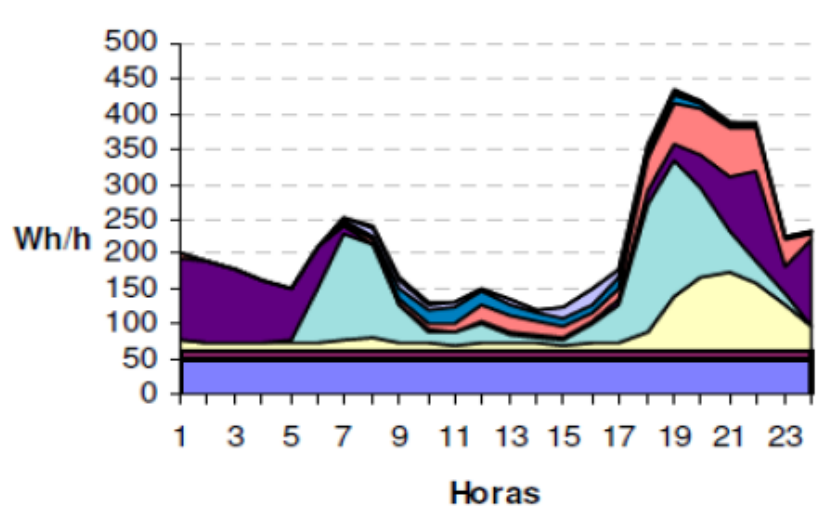

Microondas

- Lava Roupa

$\square$ Ferro

口 Som

口TV

- Condicionamento Ambiental

口 Chuveiro

口 Lampadas

Freezer

Geladeira

Figura 65: Curva de carga diária média no Brasil.

Fonte: Eletrobrás/Procel, 2012.

Portanto esse seria um dimensionamento de sistema ajustado com intuito de gerar energia necessária apenas para uma residência, sem levar em consideração um futuro abastecimento de um carro elétrico, ou vender energia excedente para concessionárias.

No Brasil ainda não existe uma política que conceda um valor comercial para vender energia excedente. A ANEEL através da resolução normativa $N^{\circ} 482$, de 17 de abril de 2012, estabelece as condições gerais para o acesso de microgeração e minigeração distribuída aos sistemas de distribuição de energia elétrica, o sistema de compensação de energia elétrica, e dá outras providências, que permitem:

..."sistema de compensação de energia elétrica: sistema no qual a energia ativa injetada por unidade consumidora com microgeração distribuída ou minigeração distribuída é cedida, por meio de empréstimo gratuito, à distribuidora local e posteriormente compensada com o consumo de energia elétrica ativa dessa mesma unidade consumidora ou de outra unidade consumidora de mesma titularidade da unidade consumidora onde os créditos foram gerados, desde que possua o mesmo Cadastro de Pessoa Física (CPF) ou Cadastro de Pessoa Jurídica (CNPJ) junto ao Ministério da Fazenda".

A microgeração distribuída é tida como uma central geradora de energia elétrica, com potência instalada menor ou igual a $100 \mathrm{~kW}$ e que utilize fontes com base em energia hidráulica, solar, eólica, biomassa ou cogeração qualificada, conforme regulamentação da ANEEL, conectada na rede de distribuição por meio de instalações de unidades consumidoras. 
Outro fator importante a ser ressaltado é a quantidade de módulos fotovoltaicos que esse tipo de dimensionamento por $\mathrm{kWh} /$ dia proporcionou, que é de 62 painéis, número considerado "normal" em relação a sua área ocupada (aproximadamente $100 \mathrm{~m}^{2}$ ) em um terreno de uma residência padrão, esse dado pode ser visto nos cálculos da tabela no anexo 7.2. A instalação dos módulos fotovoltaicos no telhado é um procedimento já consolidado no mercado de energia fotovoltaica.

Uma alternativa já comercial em alguns países da Europa é um tipo de painel que tem o formato de uma telha normal. O produto tem aumentado e diversificado o comercio de energia fotovoltaica, a fim de integrar-se melhor na paisagem. As telhas são feitas de pequenos painéis solares para serem aplicadas no lado liso da telha. A diferença de um telhado tradicional é bem perceptível, mas estamos longe do impacto estético de um telhado feito inteiramente por painéis solares. Além disso, a instalação requer uma reconstrução parcial do telhado e o custo pode ser muito elevado, além de que podem sofrer uma perda de área útil com a sombra do painel. São feitas exatamente como as telhas tradicionais, apenas em sua superfície que é acoplada a carcaça de um painel fotovoltaico. As vantagens é que elas possuem um atrativo visual e são bem semelhantes a telhados tradicionais, eles não precisam de instaladores com certas certificações. Isto significa que, em áreas sujeitas a normas rígidas em se tratando de paisagem, as telhas permitem obter as autorizações necessárias para serem instaladas (AERAFRANCERAM, 2014). A figura 66 mostra as telhas fotovoltaicas. 


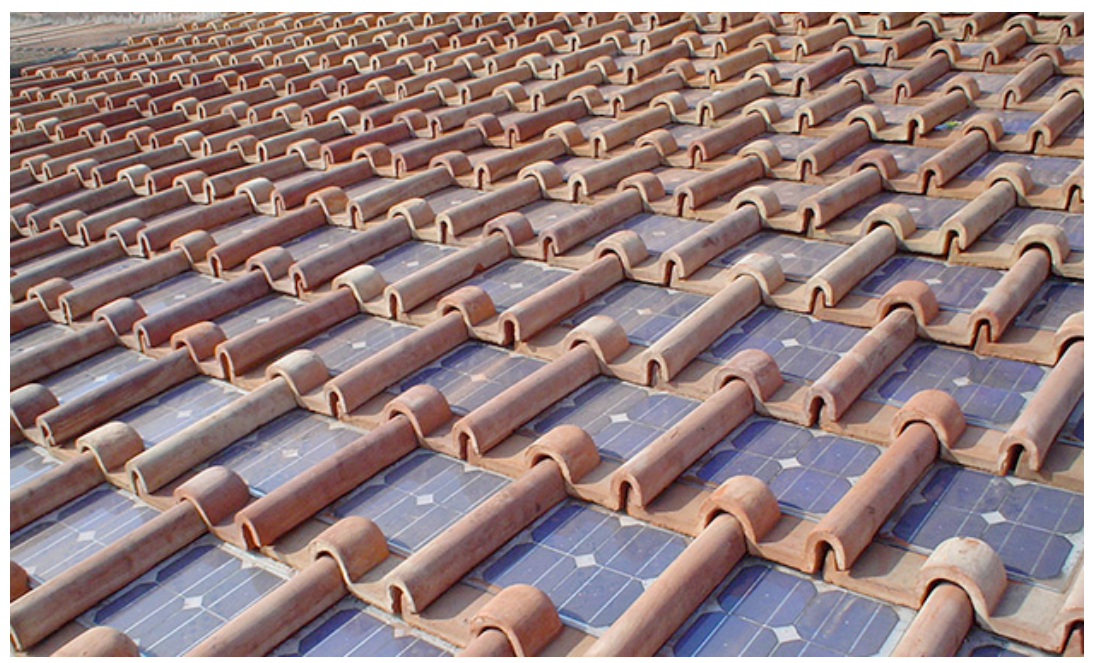

Figura 66: Telhas Fotovoltaicas.

Fonte: Area France, 2014. Disponível em: http://www.areafranceram.com/it

Quanto ao armazenamento e estocagem do hidrogênio notou-se que não há necessidade de grandes quantidades de cilindros para esse tipo de utilização residencial. Foram previstos a utilização de 6 cilindros (de acordo com a estimativa de demanda) que ficarão dispostos em uma área aberta, de acordo com as normas de seguranças citadas na revisão bibliográfica, o que não acarretou grandes mudanças no desenho da residência, apenas foi necessário um aumento da área útil de um cômodo que serviu como uma "casa de máquinas" para controle do sistema.

A mudança pode ser considerada uma "evolução projetual" dos ambientes na qual futuramente as casas terão de dispor de um espaço para o controle e automação de sistemas de informatização considerando as necessidades e expectativas dos usuários.

Uma comparação histórica da evolução projetual dos espaços, pode ser feita, onde vários ambientes foram se modificando, por exemplo, a cozinha residencial que no século $X X$, foi sem dúvida o ambiente que mais passou por transformações. De acordo com Oliveira, 2010 a cozinha apresentou diversas alterações significativas em tamanho, implantação na casa e utilização dos seus equipamentos, decorrente das mudanças sociais sucessivas, além de modificações arquitetônicas e a contínua oferta de novos produtos manufaturados de alta tecnologia que o mercado propõe. 
A atividade projetual deve contemplar as necessidades dos usuários, o seu contexto de uso, suas relações culturais e lutar para expressar a originalidade de ideias. Sabe-se que nenhum projeto de arquitetura funciona, exceto se assimila ideias que são comuns às pessoas para as quais o objeto se destina, contudo, não podemos nos afastar da sociedade, pelo contrário, devemos participar da transformação das ideias sobre o mundo e as relações sociais através dos objetos.

\subsection{AПÁLISE DE SENSIBILIDADE DO AUCENGO DA

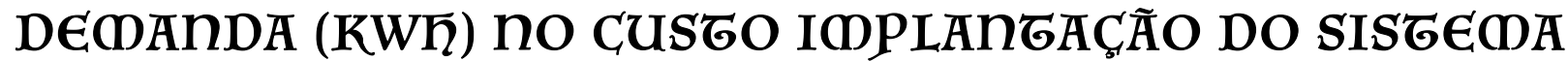

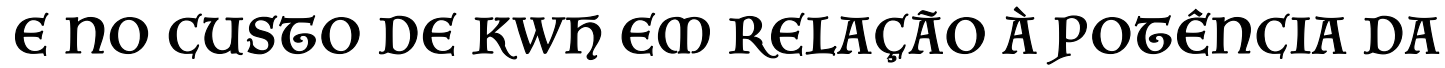 CÉLIULA.}

Neste trabalho foi feita a análise de sensibilidade, que procura determinar o efeito de uma variação de um determinado item no seu valor total. Pode ser um instrumento útil em diferentes áreas para determinar a importância de uma variável sobre o resultado final de outra. Foi feita a simulação para 4 tipos de demanda mensais, tais quais, $100 \mathrm{kWh} /$ mês que representa um valor mais baixo, $150 \mathrm{kWh} /$ mês que representa aproximadamente a média brasileira, $300 \mathrm{kWh} / \mathrm{mês}$ um valor entre a média e o valor escolhido para a casa modelo que é de $450 \mathrm{kWh} / \mathrm{mês}$.

Também foram escolhidos 4 valores diferentes de potência (watts) para as simulações, tais quais, $3 \mathrm{~kW}$ que é o valor mais baixo, $5 \mathrm{~kW}$ que é o valor escolhido para a casa modelo, 10 kW que é um valor entre o escolhido para a casa modelo e o valor que a CPFL disponibiliza em média para as residências urbanas que é de $15 \mathrm{~kW}$ aproximadamente. Todos os gráficos utilizados nesta análise foram extraídos das Tabelas em no Anexo 7. A potência (watts) total do sistema implica na condição de escolha dos equipamentos, pois a soma das potências dos equipamentos (eletrodomésticos) utilizados não pode ultrapassar a potência total do sistema.

Como se pode notar no gráfico 08 extraído da Tabela no Anexo 7.1. feita da CaC mais usada em estacionárias de pequeno porte ( $5 \mathrm{~kW}$ de potência), a análise de sensibilidade do 
aumento da demanda (consumo energético da residência) vai diminuindo o preço do kWh conforme o consumo energético aumenta. Já o custo da implantação do sistema vai aumentando conforme mais energia é consumida.

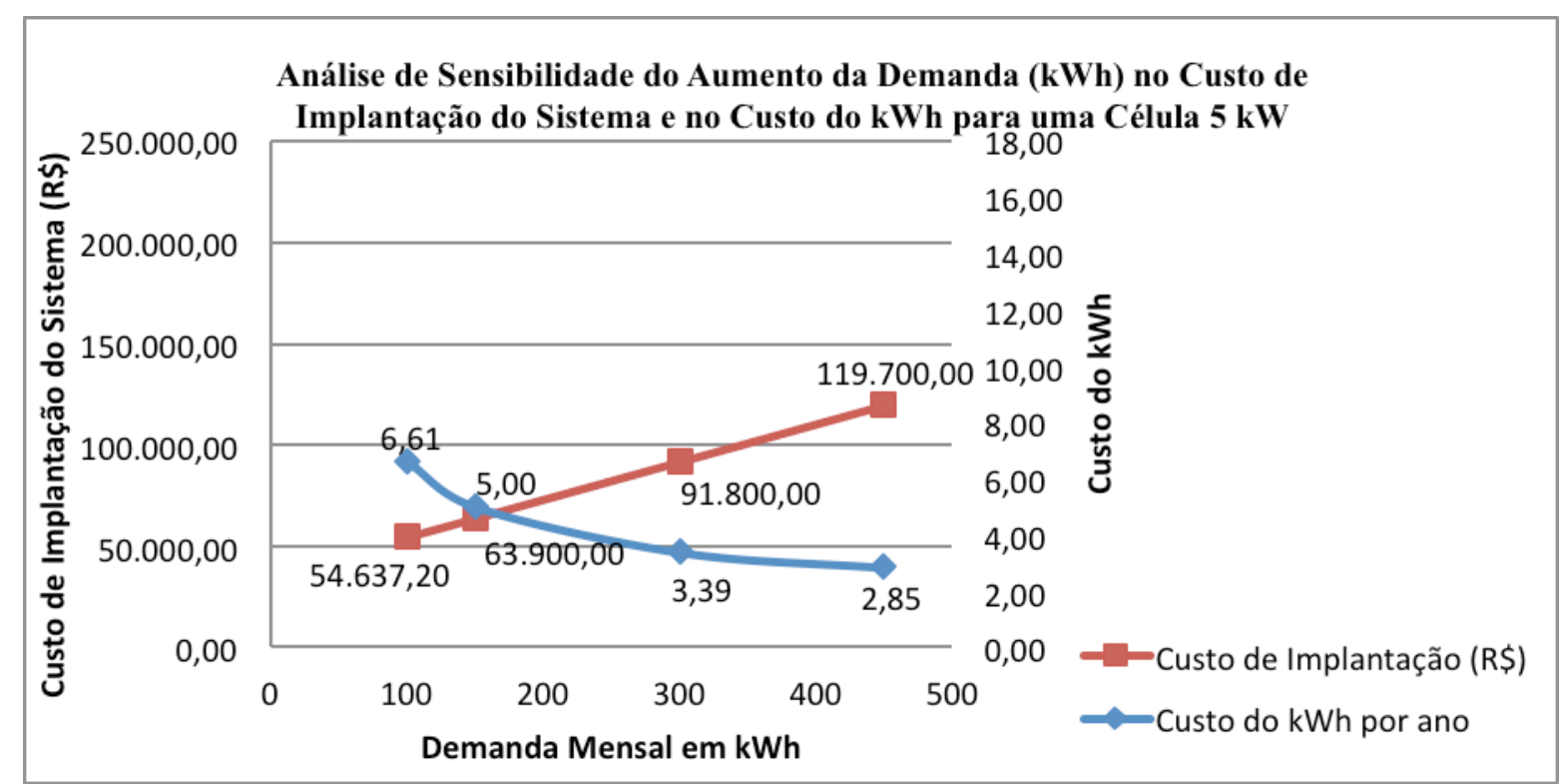

Gráfico 09: Análise de Sensibilidade do Aumento da Demanda (kWh) no Custo de Implantação do Sistema e no Custo do kWh para uma Célula $5 \mathrm{~kW}$

Fonte: Elaboração própria.

O custo do kWh sob uma demanda média brasileira (150 kWh/mês) sairia a 6,61 reais. No entanto para o consumo energético escolhido para a residência, que é de $450 \mathrm{kWh}$, sairia a \$ 2,85 reais. Se considerarmos o custo do kWh de uma concessionária do estado sudeste, como a CPFL Paulista, seria de $\mathrm{R} \$ 0,31686$ (tarifa prevista até 7/04/2015), uma das tarifas mais baratas no país, já a tarifa mais cara é a da ETROACRE, R\$ 0,42798 (ANEEL, 2014). Podemos notar que os valores ainda são muito altos em comparação a rede elétrica de distribuição convencional, no entanto não são contabilizados os danos ambientais causados pelo fornecimento de energia elétrica baseada em hidroelétricas. O custo de implantação do sistema para a demanda escolhida (450 kWh/mês) fica em torno de $\$ 120.000$ reais.

O custo da implantação de um sistema de energia elétrica fotovoltaica (composto somente de painéis fotovoltaicos) para um consumo de $450 \mathrm{kWh} / \mathrm{mês}$ seria estimado 
aproximadamente em $\$ 20.000$ reais (8 painéis de 120W a \$2550,00 reais) (ENERGIA SOLAR RESIDENCIAL, 2014). Esse sistema foi dimensionado para estar conectado a rede, se fossemos utilizar baterias convencionais para armazenar energia suficiente parar ser autônomo (sistema isolado) o cálculo seria outro aumentando consideravelmente o custo.

O gráfico da análise de sensibilidade do aumento da demanda também foi simulado para CaC de 3kW para uma análise de potência mínima que possa ser utilizada em uma residência, lembrando que a soma das potências dos equipamentos utilizados na residência não pode ultrapassar os $3 \mathrm{~kW}$. No gráfico 09 da Tabela em Anexo 7.1. de $3 \mathrm{~kW}$ podemos notar que houve uma baixa no preço do kWh para o consumo do modelo escolhido (de $450 \mathrm{kWh} / \mathrm{mês}$ ) e sairia a \$ 2,42 reais o $\mathrm{kWh}$.

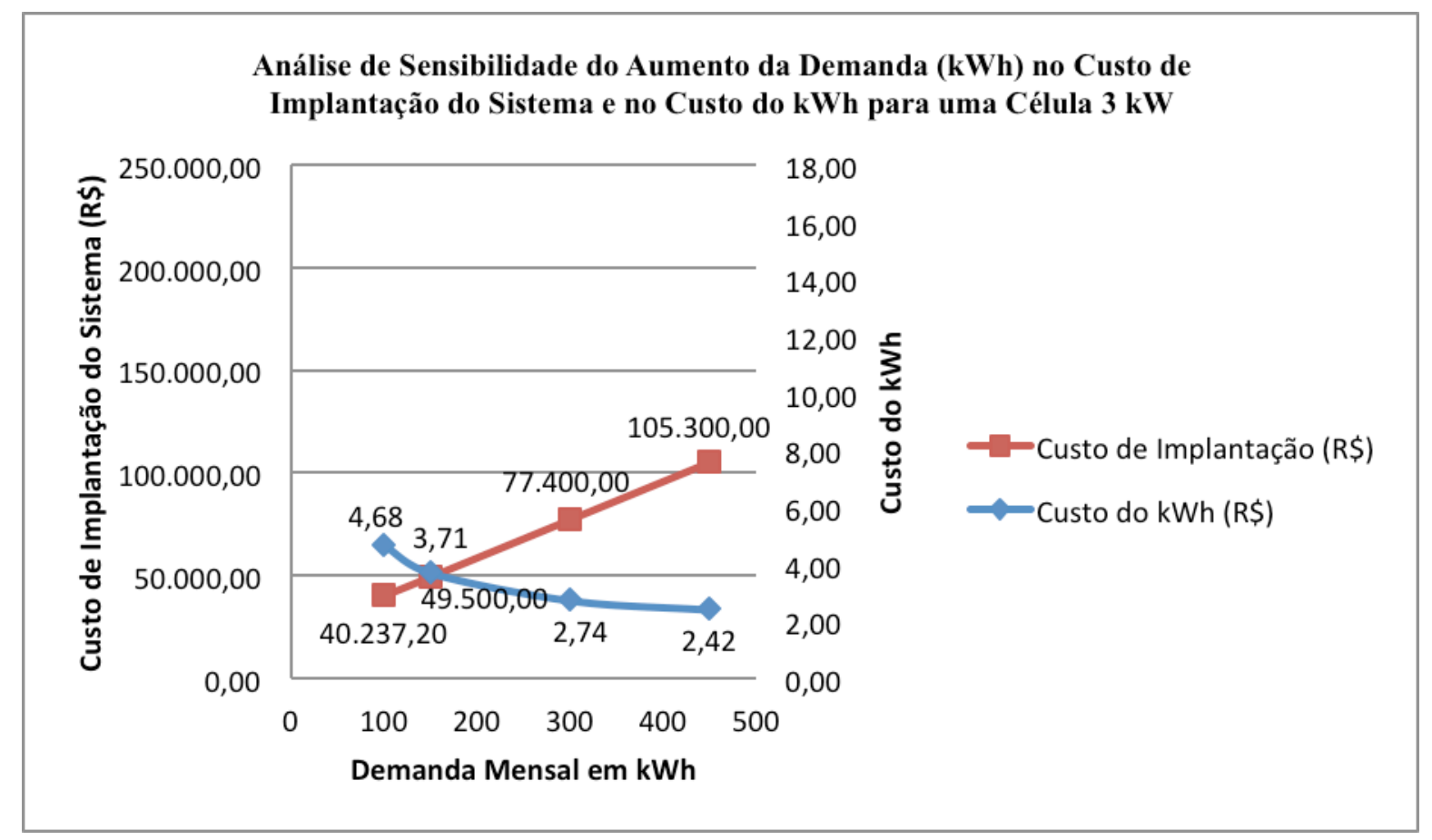

Gráfico 10: Análise de Sensibilidade do Aumento da Demanda (kWh) no Custo de Implantação do Sistema e no Custo do kWh para uma Célula $3 \mathrm{~kW}$

Fonte: Elaboração própria.

Outras simulações foram feitas para uma célula de $10 \mathrm{~kW}$ e $15 \mathrm{~kW}$ demonstrando uma folga de potência total para a residência, podendo assim aumentar o consumo ou o número de aparelhos eletrodomésticos utilizados em uma residência. 


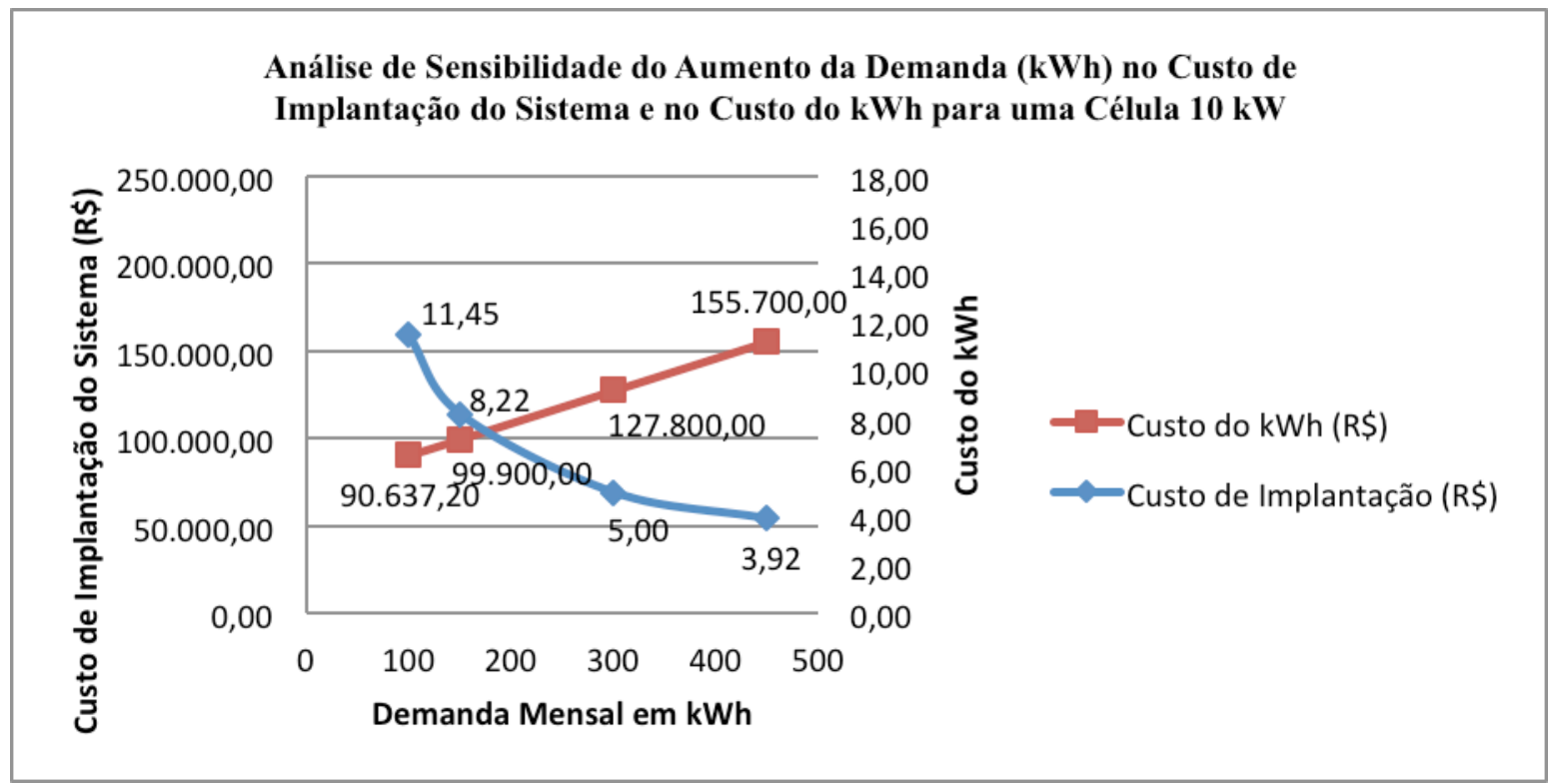

Gráfico 11: Análise de Sensibilidade do Aumento da Demanda (kWh) no Custo de Implantação do Sistema e no Custo do kWh para uma Célula $10 \mathrm{~kW}$

Fonte: Elaboração própria.

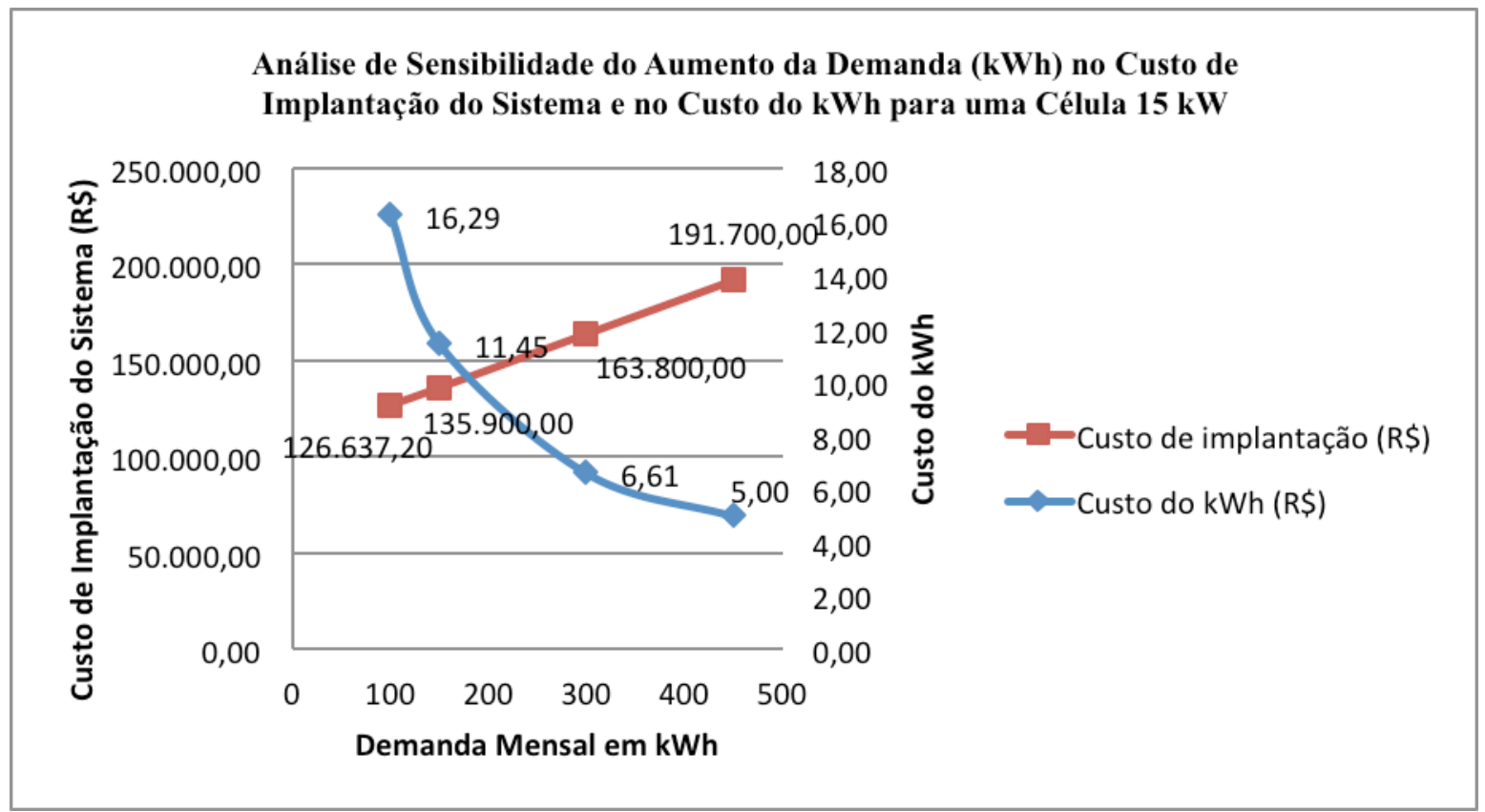

Gráfico 12: Análise de Sensibilidade do Aumento da Demanda (kWh) no Custo de Implantação do Sistema e no Custo do kWh para uma Célula $15 \mathrm{~kW}$

Fonte: Elaboração própria. 
Pela análise dos gráficos 11 e 12 (ainda da Tabela no Anexo 7.1.) quanto mais energia consumida pela residência menor sai o custo do $\mathrm{kWh}$, independente da potência, em Watts, do sistema como pode se notar nos gráficos com as potências máximas utilizadas de $10 \mathrm{~kW}$ e 15 kW. O custo da implantação do sistema sofre acréscimo com o aumento da demanda e com aumento da potência. O custo da implantação de um sistema de $3 \mathrm{~kW}$ é de 40.000,00 reais enquanto para $15 \mathrm{~kW}$ é de $126.000,00$ reais operando na faixa de menor demanda (kWh) para ambas as potências.

\subsection{CUSGO ANUAL EQUIVALENGE DOS COMPONENGES DO SISGECA}

O custo anual equivalente é um dos métodos utilizados para a escolha de equipamentos que realizarão a mesma tarefa e têm vidas úteis distintas. Para o cálculo de um custo anual equivalente (CAE), devemos sempre levar em consideração o custo equivalente a 1 ano de produção da máquina.

O custo anual equivalente projeta (de acordo com o Fator de Correção do Capital) o capital investido para o último ano de vida útil da máquina e soma ao custo anual dessa máquina, obtendo assim o custo anual equivalente de todo o projeto. O fator de correção levará em consideração a taxa de retorno, ou taxa de custo de capital e o tempo de vida útil do equipamento. A Taxa Mínima de Atratividade (TMA) é uma taxa de juros que representa o mínimo que um investidor se propõe a ganhar quando faz um investimento, ou o máximo que uma pessoa se propõe a pagar quando faz um financiamento. Ao se utilizar uma TMA como taxa de juros de referência, é entendida como a taxa de desconto ao qual aplicam-se métodos em comparação em relação a um período de tempo, como o Valor Presente Líquido ou o Custo Anual para se determinar a viabilidade financeira de um investimento ou empréstimo. Taxa mínima de retorno ou taxa de atratividade (TMAR) é a taxa de juros abaixo da qual uma empresa 
ou investidor considera não atrativa para realização de um empreendimento. No trabalho foi utilizado uma TMAR de 10\%, que é considerada uma alta taxa de juros.

\section{Custo Anual Equivalente dos Componentes do Sistema pela Demanda Energética.}

Os gráficos 13, 14, 15 e 16 são referentes ao custo anual equivalente dos componentes do sistema pela demanda energética e foram extraídos da Tabela do Anexo 7.6. Foi realizada a análise do CAE pela demanda $(100,150,300$ e $450 \mathrm{kWh})$ e para cada gráfico foi utilizado potências diferentes (células de 3, 5, 10 e $15 \mathrm{~kW}$ ). Foi feita essa separação dos cálculos devido à diferença entre as formas de dimensionar o sistema, ou por demanda energética ou por potência requerida.

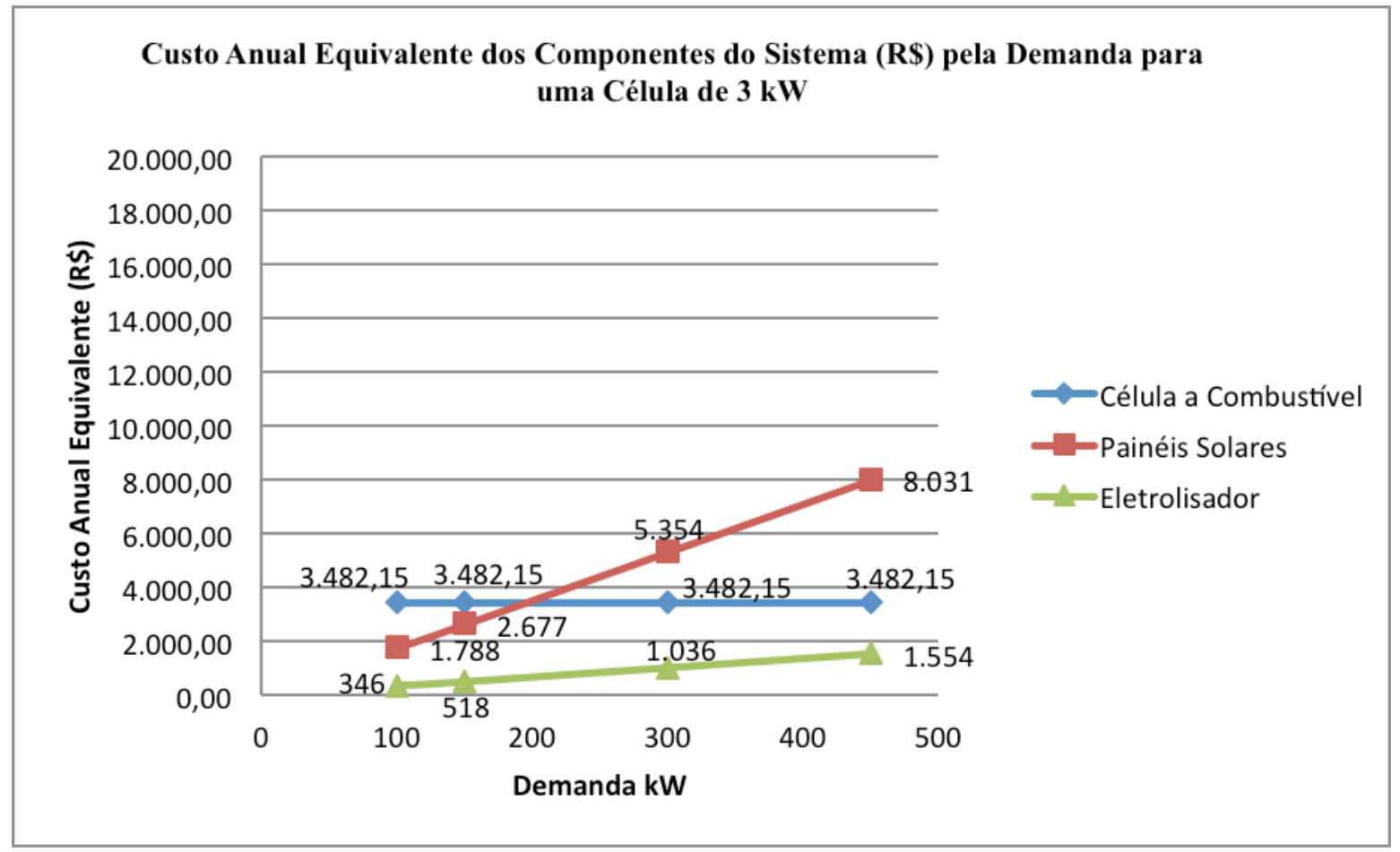

Gráfico 13: Custo Anual Equivalente dos Componentes do Sistema $(R \$)$ pela Demanda para uma Célula de $3 \mathrm{~kW}$ Fonte: Elaboração própria. 


\section{em residências}

Como o eletrolisador e a célula a combustível continuam do mesmo tamanho (potência de $3 \mathrm{~kW}$ ) podemos notar através do gráfico 12 que somente o CAE do painel fotovoltaico é alterado, pois quando a demanda energética da casa aumenta, o consumo de energia dos painéis fotovoltaicos deve aumentar proporcionalmente, o eletrolisador também sofre um aumento.

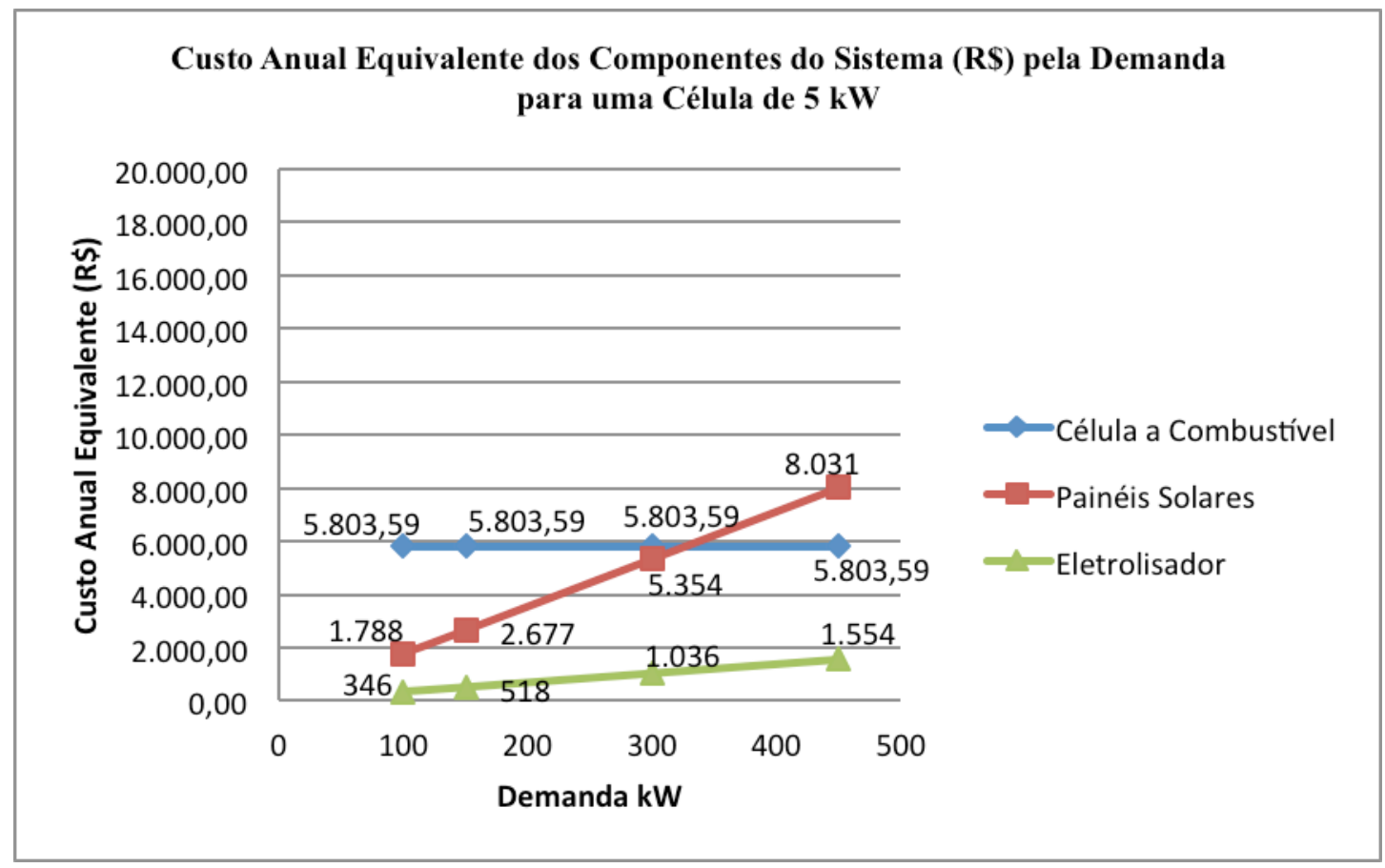

Gráfico 14: Custo Anual Equivalente dos Componentes do Sistema (R\$) pela Demanda para uma Célula de $5 \mathrm{~kW}$ Fonte: Elaboração própria.

A potência no gráfico 13 aumentou para $5 \mathrm{~kW}$, o preço da célula a combustível foi para $\$$ $5.803,00$ reais, concluindo-se que o sistema aumenta de preço se aumentarmos a necessidade de potência em watts.

No gráfico 15 aumentou-se a potência para $10 \mathrm{~kW}$ e o preço da célula foi para \$ $11.607,18$ reais, sendo o componente mais caro do sistema. 


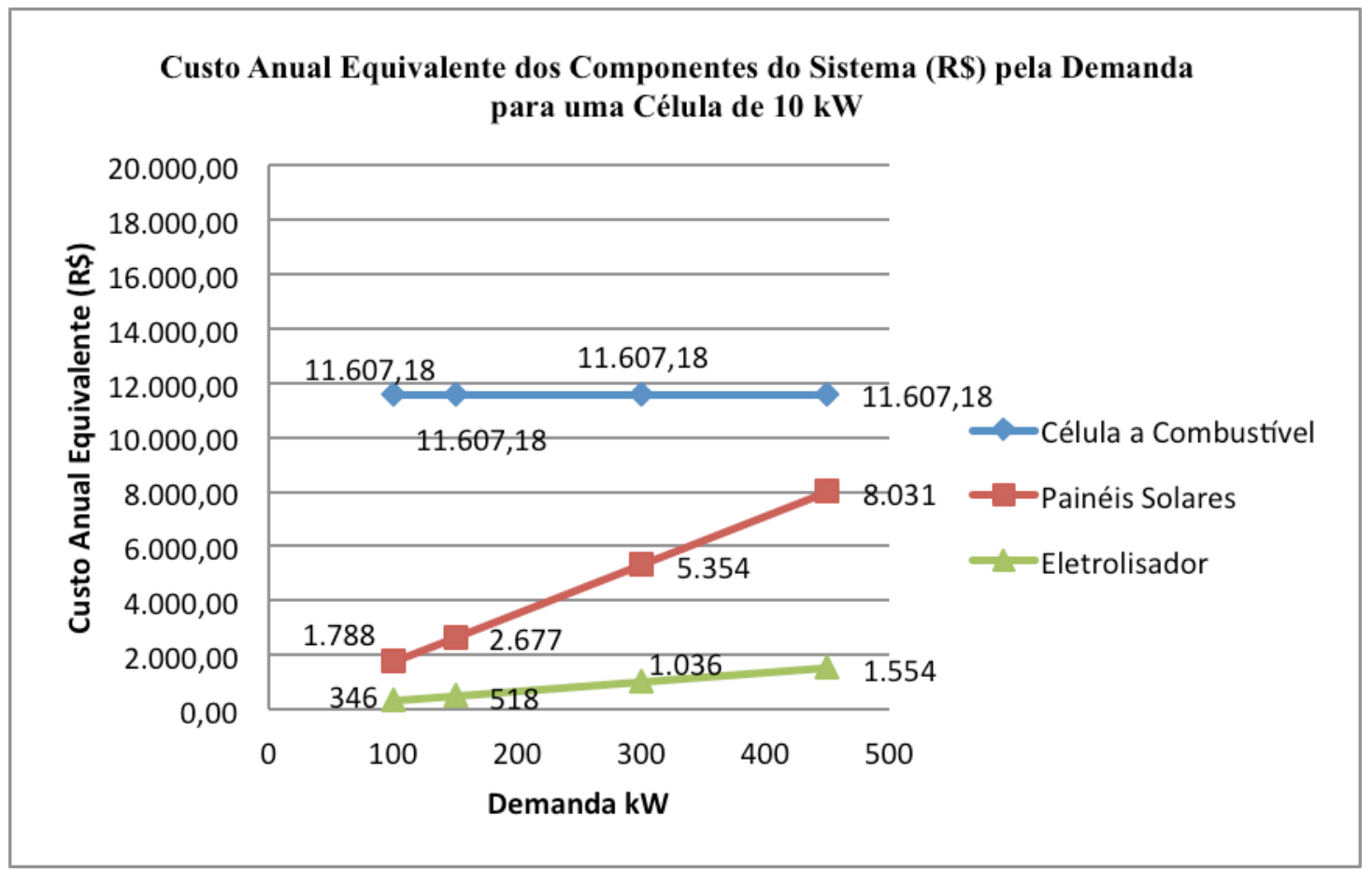

Gráfico 15 : Custo Anual Equivalente dos Componentes do Sistema (R\$) pela Demanda para uma Célula de $10 \mathrm{~kW}$ Fonte: Elaboração própria.

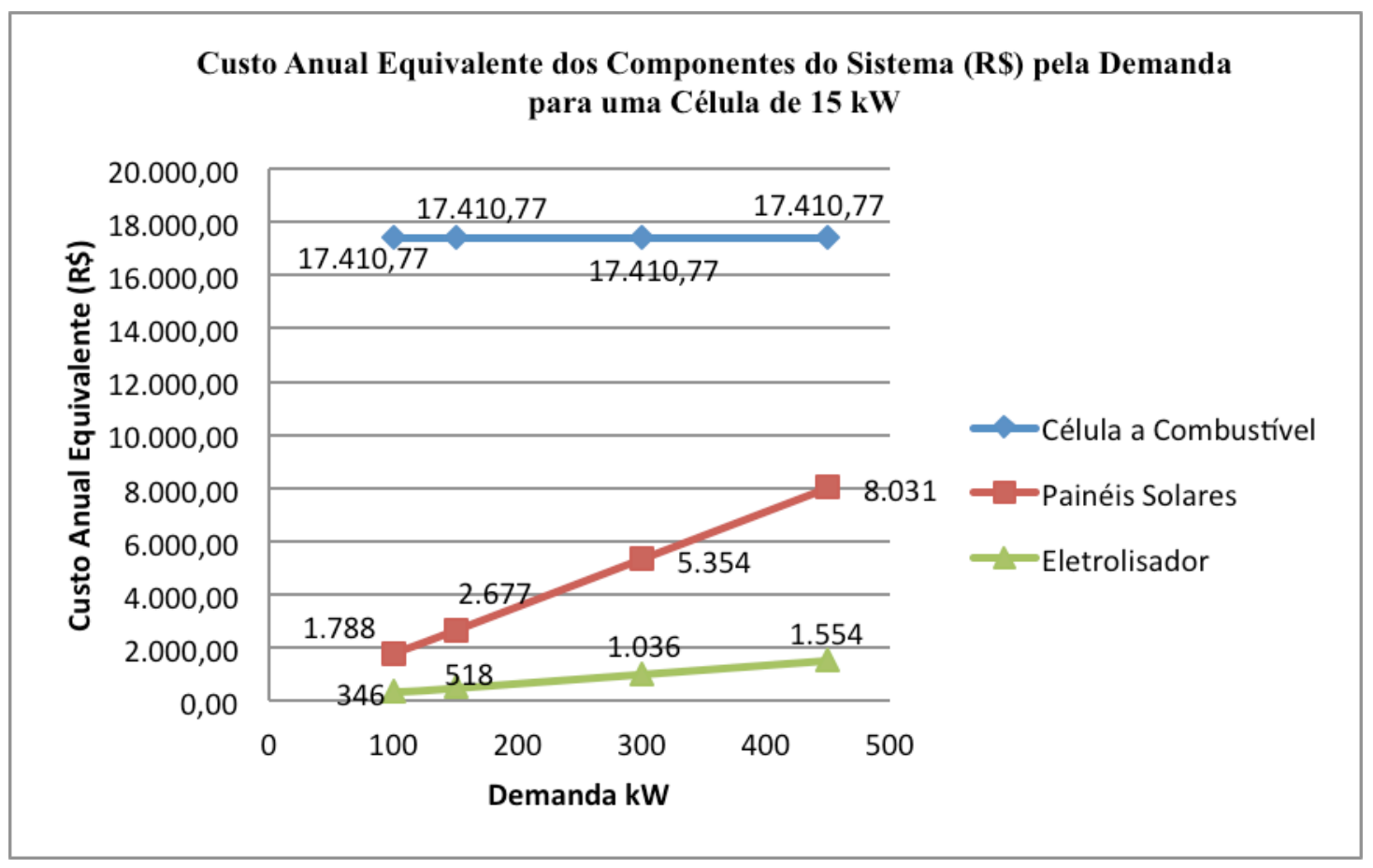

Gráfico 16: Custo Anual Equivalente dos Componentes do Sistema (R\$) pela Demanda para uma Célula de $15 \mathrm{~kW}$ Fonte: Elaboração própria. 
Nos gráficos 15 e 16 (assim como em todos os gráficos de cálculo) nota-se que o custo do painel fotovoltaico e do eletrolisador continuam o mesmo para todas as potências $(3,5,10$ e $15 \mathrm{~kW}$ ), pois a demanda de consumo energético para a residência é a mesma ou seja, 100, 150, 300 ou $450 \mathrm{kWh} / \mathrm{mês}$, porém o custo da célula é que vai variar de acordo com o aumento da potência. Portanto o CAE do sistema só é alterado pelo aumento da potência da célula em watts.

\section{Custo Anual Gquivalente dos Componentes do Sistema pela Potência da Célula.}

Os gráficos 17, 18 e 19 são referentes a Tabela em Anexo 7.7. e mostram o custo anual equivalente (CAE) para os componentes do sistema em relação às potências (em watts) que a célula pode assumir. O custo dos painéis fotovoltaicos sempre é maior para todas as potências assumidas devido ao processo de produção de hidrogênio pela eletrólise da água necessitar de muita energia.

Apesar dos painéis solares já estarem sendo vendidos em escala no mercado atual, ele é o componente de maior custo para o sistema. O consumo de hidrogênio para uma célula de 15 kW é grande e consequentemente a quantidade de painéis fotovoltaicos necessários aumenta muito o custo total do sistema. No entanto a geração de energia (kWh) é alta.

O gráfico 16 mostra que com o aumento da potência há o aumento do CAE, e o CAE dos painéis solares é superior ao do eletrolisador e da célula a combustível. O CAE da célula a combustível é o mais baixo dentre eles. 


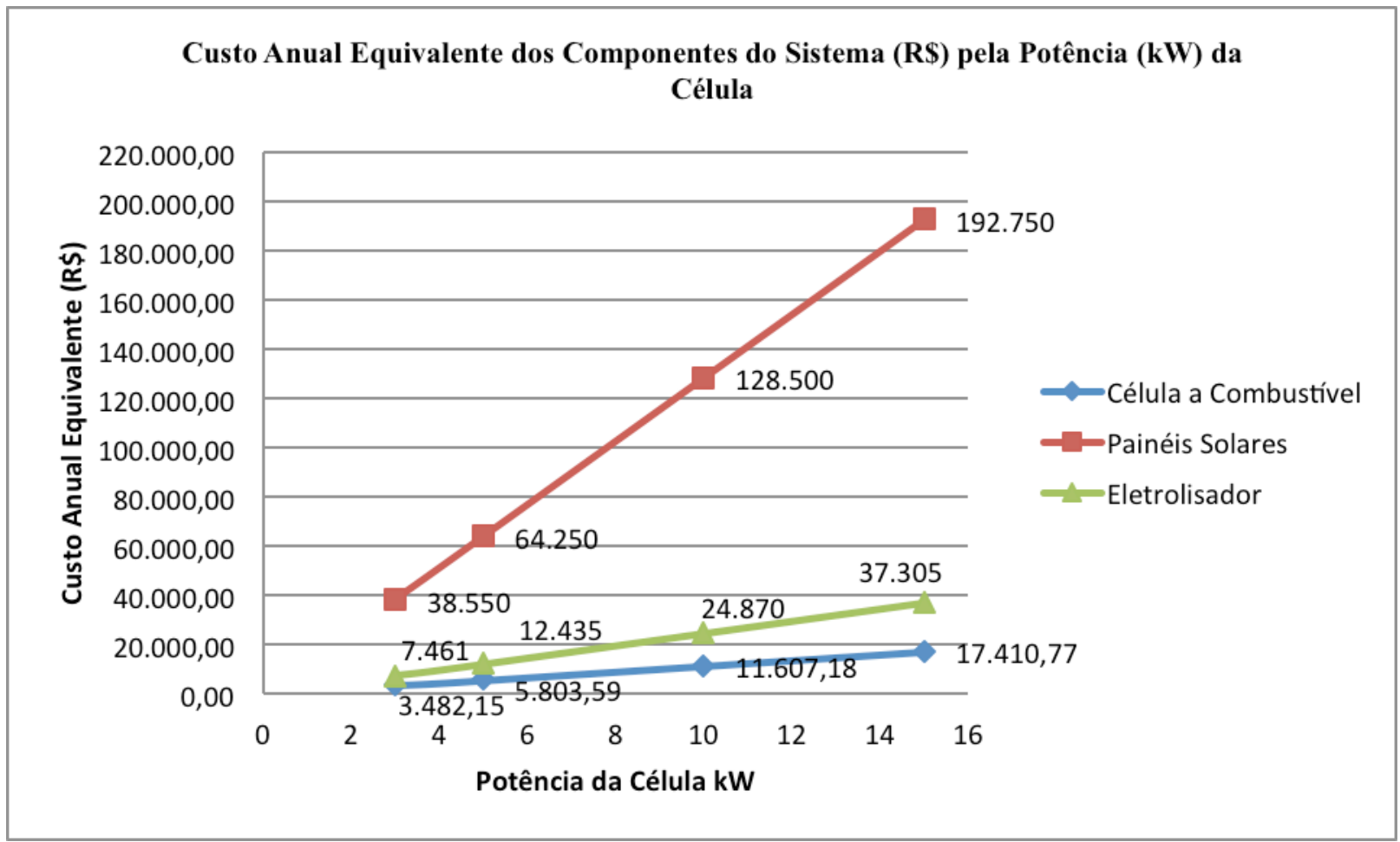

Gráfico 17: Custo Anual Equivalente dos Componentes do Sistema $(R \$)$ pela Potência $(k W)$ da Célula.

Fonte: Elaboração própria.

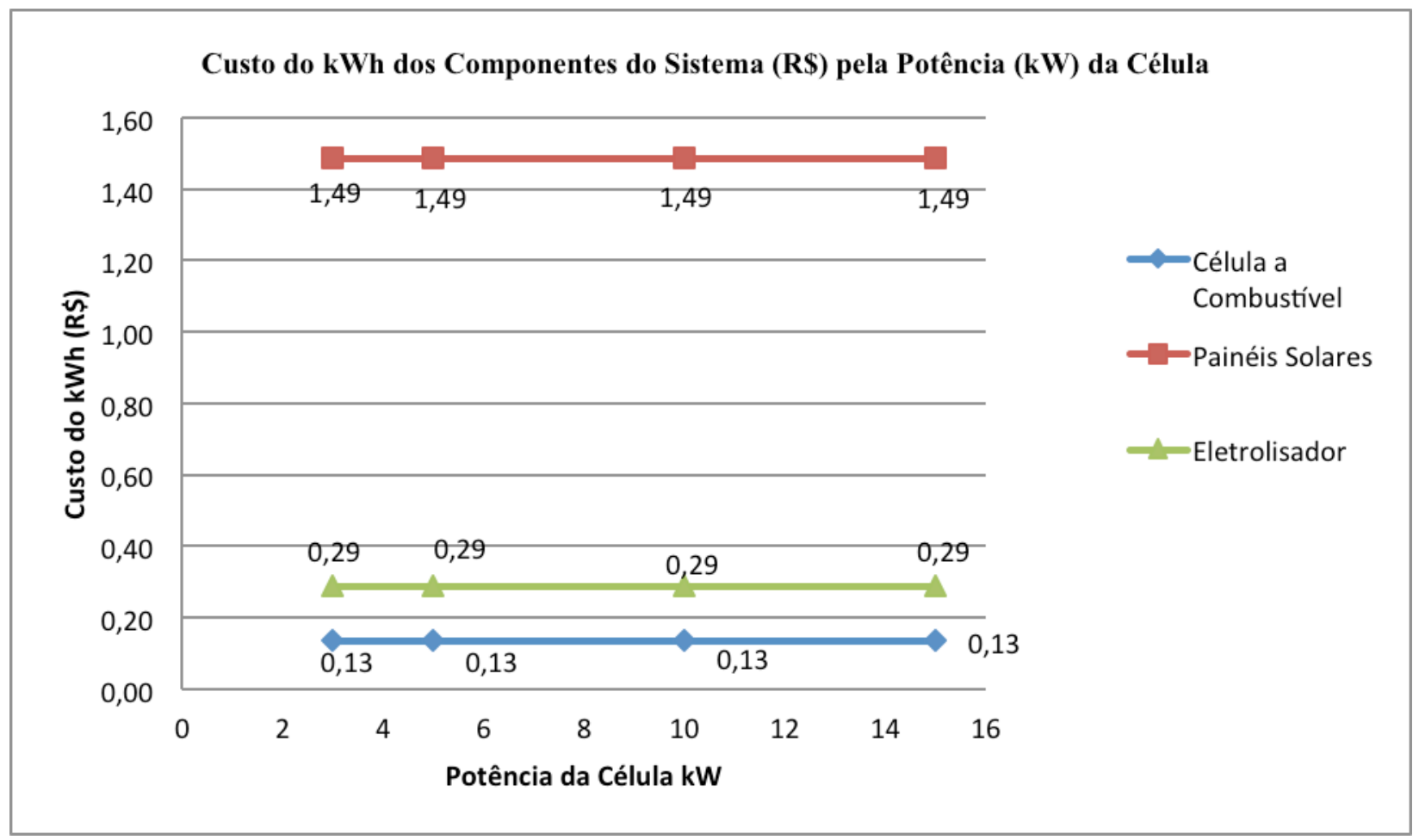

Gráfico 18: Custo do kWh dos Componentes do Sistema $(\mathrm{R} \$)$ pela Potência $(\mathrm{kW})$ da Célula.

Fonte: Elaboração própria. 
De acordo com o gráfico 19 o custo do kWh dos componentes do sistema é sempre constante mesmo aumentando as potências, esse fato será explicado a seguir.

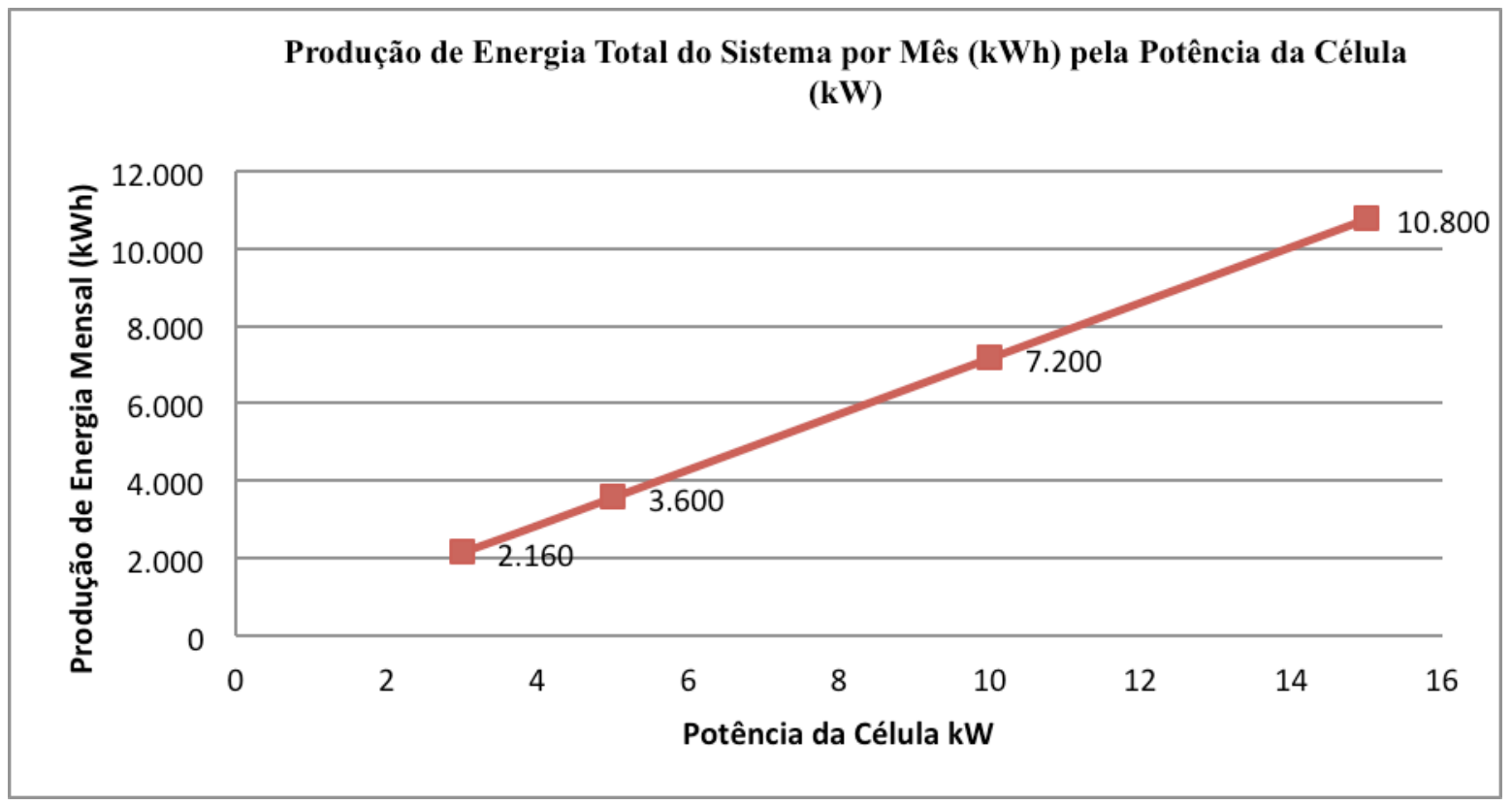

Gráfico 19: Produção de energia total do sistema por mês pela potencia da célula.

Fonte: Elaboração própria.

O gráfico 24 mostra o quanto de energia $(\mathrm{kWh})$ as células de 3, 5, 10 e $15 \mathrm{~kW}$ podem produzir se forem utilizadas em sua potência máxima. Para a residência modelo a demanda calculada foi de $450 \mathrm{kWh} / \mathrm{mês}$, portanto se a CaC estivesse trabalhando full time haveria uma sobra de $3.150 \mathrm{kWh} / \mathrm{mês}(3.600$ - 450) dos quais se houvesse uma política estatal que ajudasse o processo de venda de energia, essa casa poderia estar vendendo a energia excedente.

O gráfico 23 mostra que o custo do kWh dos componentes do sistema hidrogênio solar com célula combustível permanece constante mesmo trocando somente as potências. Isso se deve ao cálculo feito para chegarmos no preço do kWh. O cálculo é baseado no gráfico 18 da produção de energia total do sistema por mês dividido pela potência. Como por exemplo uma célula de $3 \mathrm{~kW}$ produz $2.160 \mathrm{kWh} /$ mês (produção máxima da célula operando 24 hrs com $3 \mathrm{~kW}$ ). Ao ano seria $2.160 \mathrm{kWh}$ multiplicado por 12 (12 meses) resultando em $25.920 \mathrm{kWh}$. Soma-se os CAEs do eletrolisador, célula a combustível e painel fotovoltaico resultando em um valor de $\$$ $49.493,00$ mil reais. Assim divide-se $\$ 49.493,00$ reais por $25.920 \mathrm{kWh} /$ ano resultando em 
aproximadamente $\$ 1,90$ reais o custo do $\mathrm{kWh}$ de um sistema de células a combustível movida a hidrogênio solar. O mesmo cálculo pode ser utilizado para as demais potências, porém o custo do $\mathrm{kWh}$ será sempre o mesmo (\$1,90 reais).

\subsection{ESGUDOS E COOPARAÇÕES NA AROAZENAGECD DE ГIDROGẾnIO ED CILINDROS}

O gráfico 19 foi extraído da Tabela em Anexo 7.3. e representa o número de cilindros necessários para abastecer uma residência pela demanda energética (kWh). O primeiro resultado é de uma demanda mínima de $100 \mathrm{kWh} / \mathrm{mês}$, onde seria utilizado apenas 1,25 cilindros, ou aproximando para 2 cilindros. A área em metros quadrados para alocar 2 cilindros seria de aproximadamente $1 \mathrm{~m}^{2}$. Verifica-se que a área reservada para o estoque desses cilindros é praticamente irrelevante, levando em conta todas as normas de armazenagem e segurança para alocação de cilindros de hidrogênio.

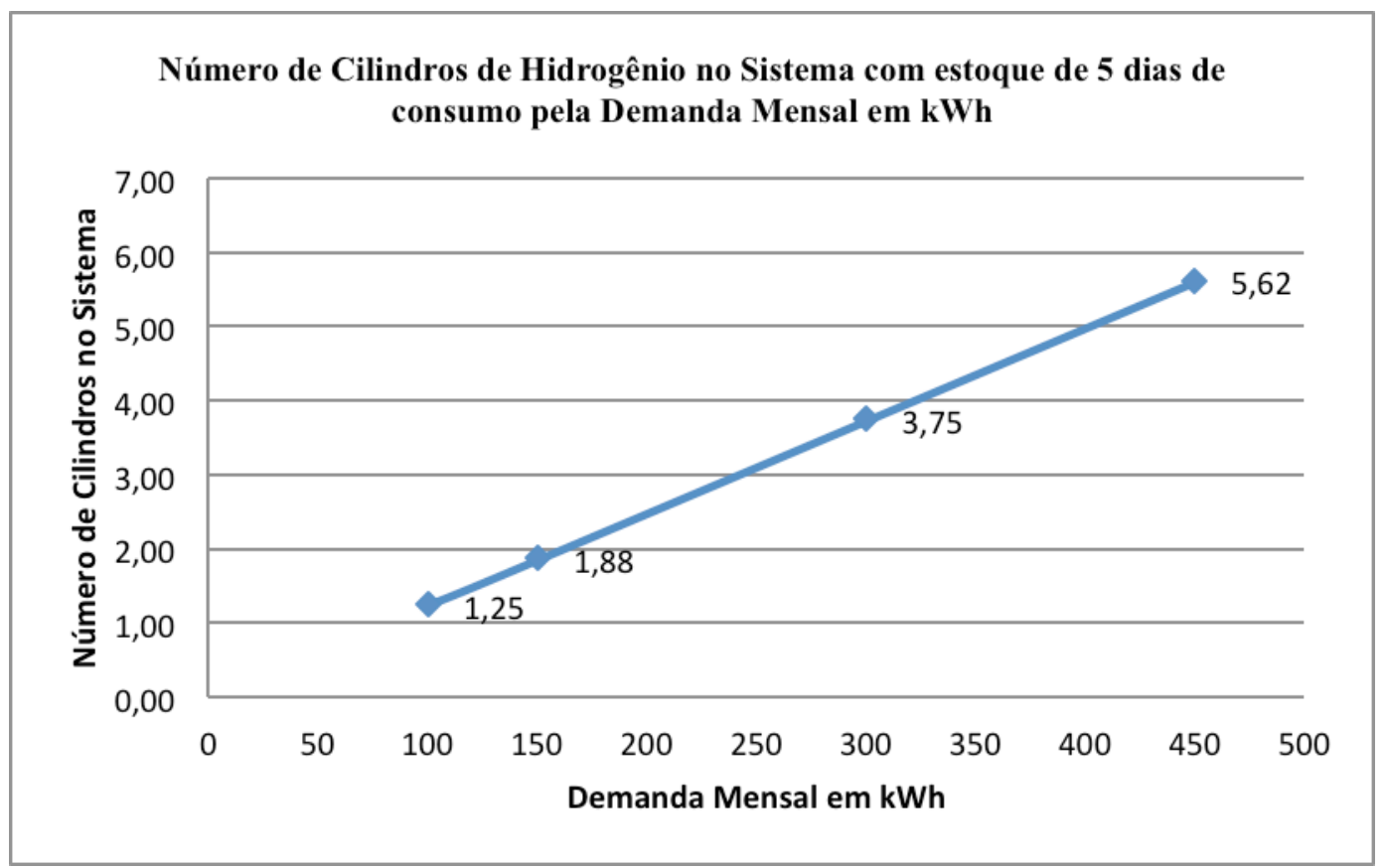

Gráfico 20: Número de cilindros de hidrogênio pela demanda mensal em kWh

Fonte: Elaboração própria. 
A última situação do gráfico 21 conta com uma demanda de $450 \mathrm{kWh} / \mathrm{mês}$, que representa a casa escolhida como modelo principal, e tem um número de cilindros de 5,63 aproximando para 6 cilindros, com uma área ocupada de 4 a $6 \mathrm{~m}^{2}$, levando em consideração todas as normas de segurança.

Pode se concluir que o número de cilindros para armazenagem de hidrogênio é pouco e ocupa uma área externa quase irrelevante, levando em conta a demanda mensal energética de uma residência típica e o estoque necessário máximo de 5 dias (para casos residenciais com sistemas elétricos isolados deve-se levar em consideração um sistema de backup de 3 a 5 dias como citado na revisão bibliográfica).

Outra maneira de estipular o número de cilindros para armazenamento é levando em consideração a potência em watts da célula a combustível. Em ambos os casos [estimativa por demanda energética $(\mathrm{kWh})$ e por potência $(\mathrm{W})$ ] a célula funciona $24 \mathrm{hrs}$ ao dia, mas no caso da estimativa pela demanda o consumo de hidrogênio é menor porque ele atende somente a necessidade estimada pela curva de demanda diária e não opera na sua potência máxima.

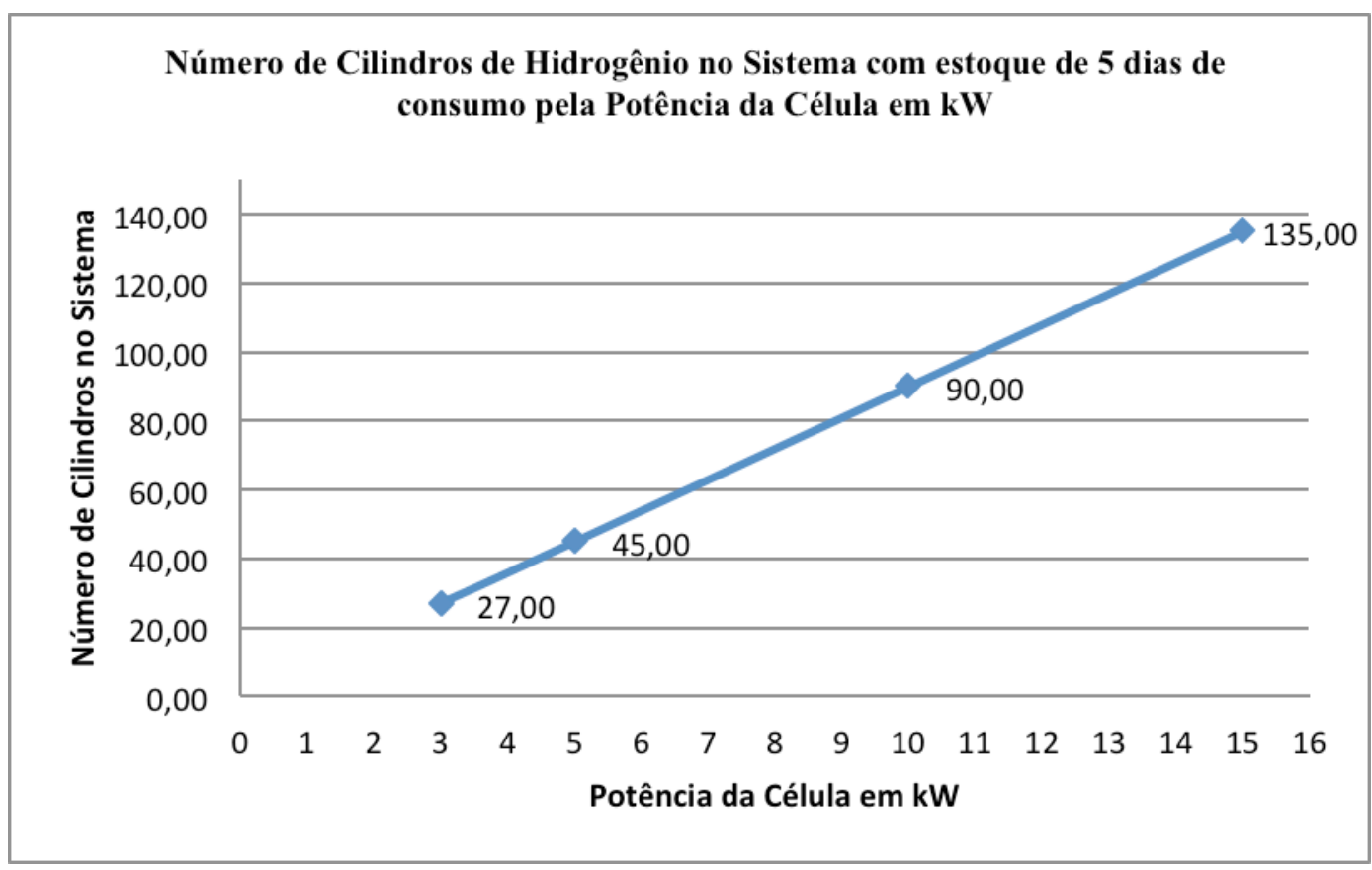

Gráfico 21: Número de cilindros de hidrogênio pela potência.

Fonte: Elaboração própria. 
De acordo com o gráfico 22da Tabela em Anexo 7.3. o número de cilindros de hidrogênio é bem maior quando o dimensionamento é feito para a utilização da célula em sua potência máxima durante as 24 horas.

Nota-se que uma célula de $3 \mathrm{~kW}$ necessitaria de 27 cilindros, levando em consideração o estoque de backup máximo de 5 dias. A área de ocupação para o armazenamento dos cilindros se tornaria um pouco mais extensa, aproximadamente de $15 \mathrm{~m}^{2}$. a figura 76 mostra o estoque de cilindros para um célula de $3 \mathrm{~kW}$.

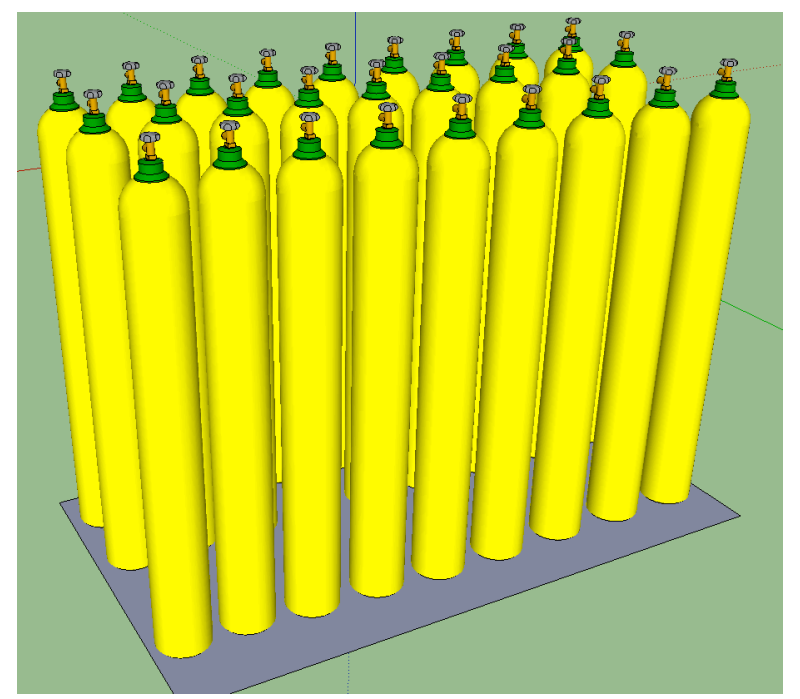

Figura 67: Estoque de vinte e sete cilindros de hidrogênio, para uma célula de $3 \mathrm{~kW}$.

Fonte: elaboração própria.

No caso de uma célula de $15 \mathrm{~kW}$ o número de cilindros de hidrogênio seria de 135 unidades. No entanto a célula estaria funcionando $24 \mathrm{hrs}$ ao dia na sua potência máxima e fornecendo energia na potência $(15 \mathrm{~kW})$, situação da qual se aproveitaria $100 \%$ da energia fornecida, barateando o custo da energia e podendo aplicar em mais residências, pois haveria kWh bastante excedente. 


\subsection{ESGUDOS E COOPARAÇÕES NA ÁREA OCUPADA PELOS PAInÉIS FOGOVOLGAICOS}

O gráfico 22 extraído da Tabela em anexo 7.4. mostra a área ocupada pelos painéis fotovoltaicos, em metros quadrados, para a obtenção de energia necessária da eletrólise da água para produção de hidrogênio em relação a potência $(\mathrm{kW})$ da célula sendo utilizada full time (24 horas) em sua potência máxima. Levou-se em consideração o painel da Kyocera de $245 \mathrm{~W}$ com área igual a $1,64 \mathrm{~m}^{2}$.

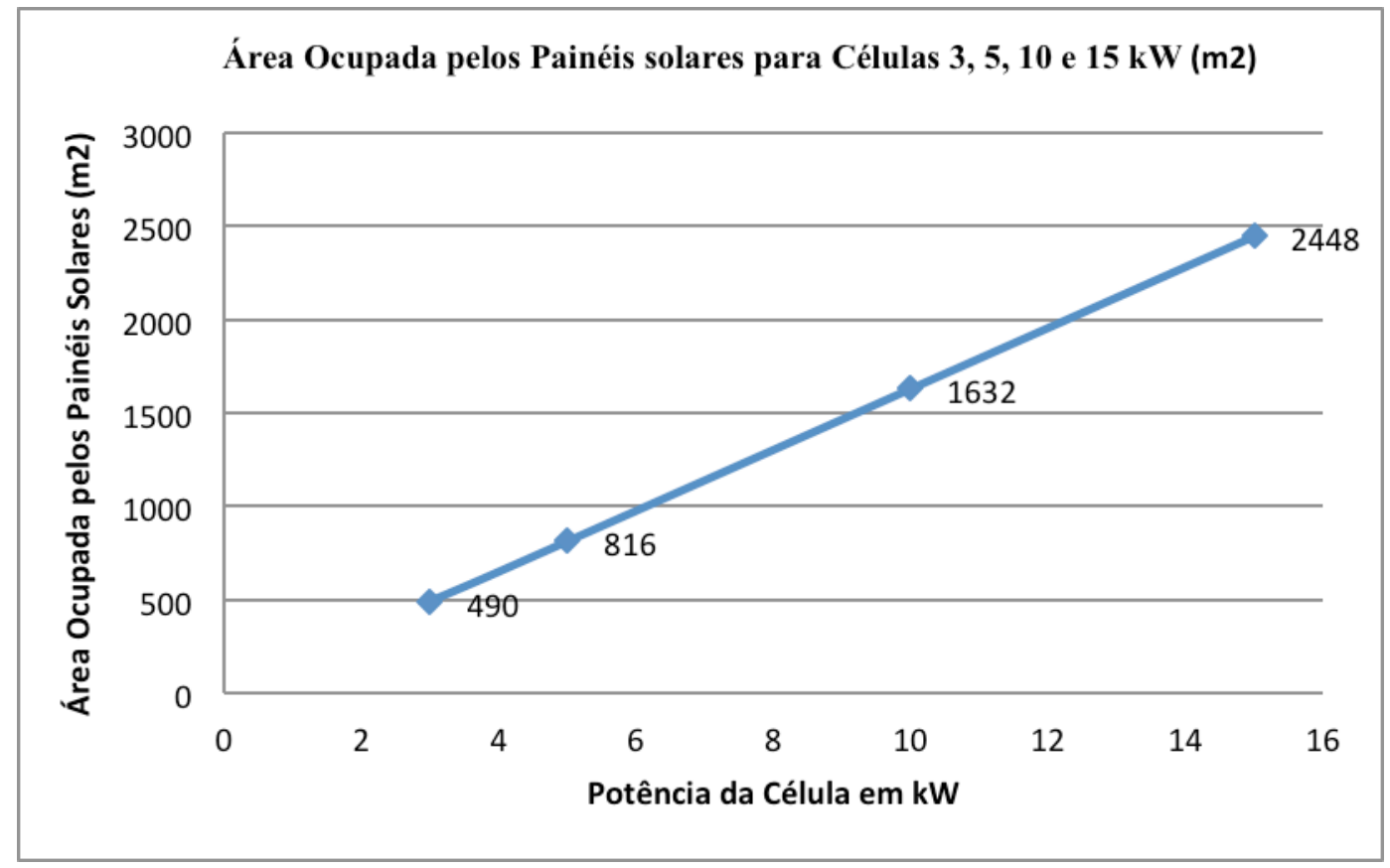

Gráfico 22: Área ocupada pelos painéis solares.

Fonte: Elaboração própria.

Nota-se que para a menor célula de $3 \mathrm{~kW}$ a área ocupada já é extensa com 490 metros quadrados. Para a célula adotada como modelo $(5 \mathrm{~kW})$ seria de 816 metros quadrados, se levado em consideração um terreno padrão urbano $(11,0 \mathrm{~m} \times 22,0 \mathrm{~m})$ com área de $242 \mathrm{~m}^{2}$ não haveria espaço disponível para a instalação dos painéis solares, só ficando viável a instalação destes em locais isolados como área rurais. A figura 68 mostra a área ocupada por painéis solares para uma célula de potencia de $3 \mathrm{~kW}$. 


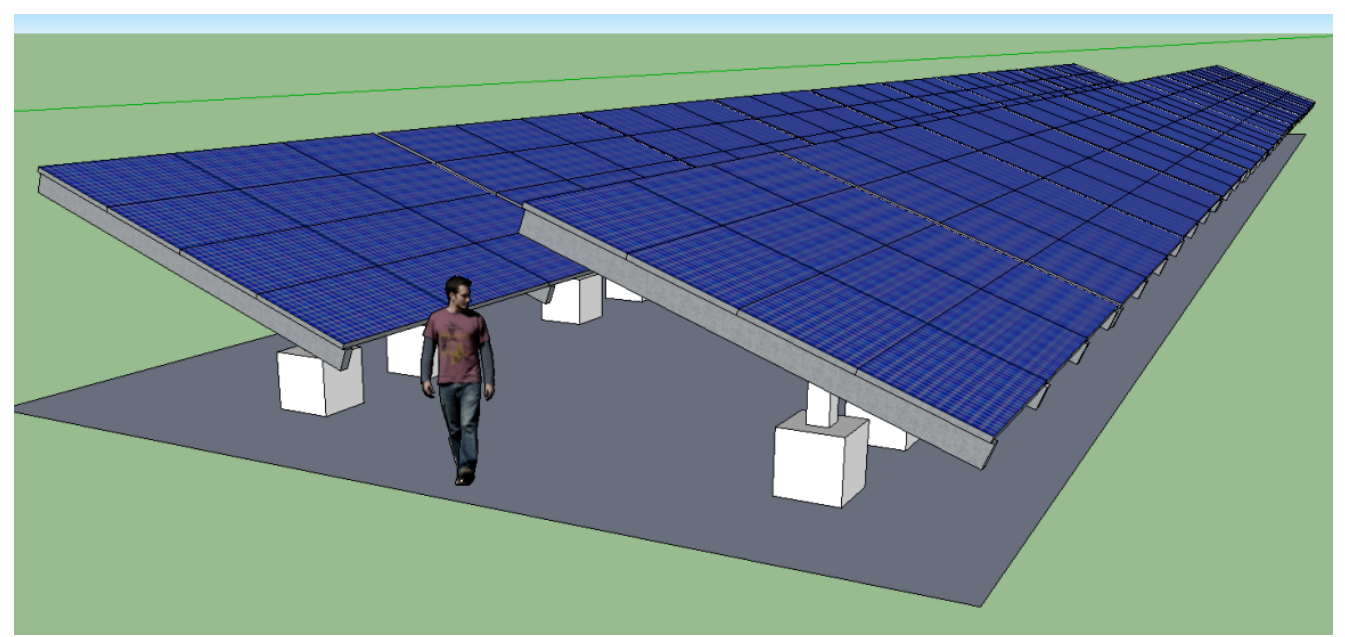

Figura 68: Área ocupada por painéis solares para uma célula de potencia de 3kW.

Fonte: elaboração própria.

\section{Análise de Sensibilidade do Aumento da Demanda ( $k W h)$ no Custo do kWh e na Area Ocupada pelos Painéis solares}

Os gráficos 23, 24, 25 e 26 são extraídos da Tabela em Anexo 7.2. No gráfico 22 a análise de sensibilidade foi feita com dados sobre o efeito do aumento da demanda energética (kWh) no Custo do kWh e na Área ocupada pelos painéis solares para uma Célula 3 kW. Notase uma queda no custo com o aumento da demanda devido ao maior aproveitamento da utilização da energia produzida pela potência da célula. A área dos painéis solares aumenta de acordo com a necessidade de aumento da demanda energética da residência. 


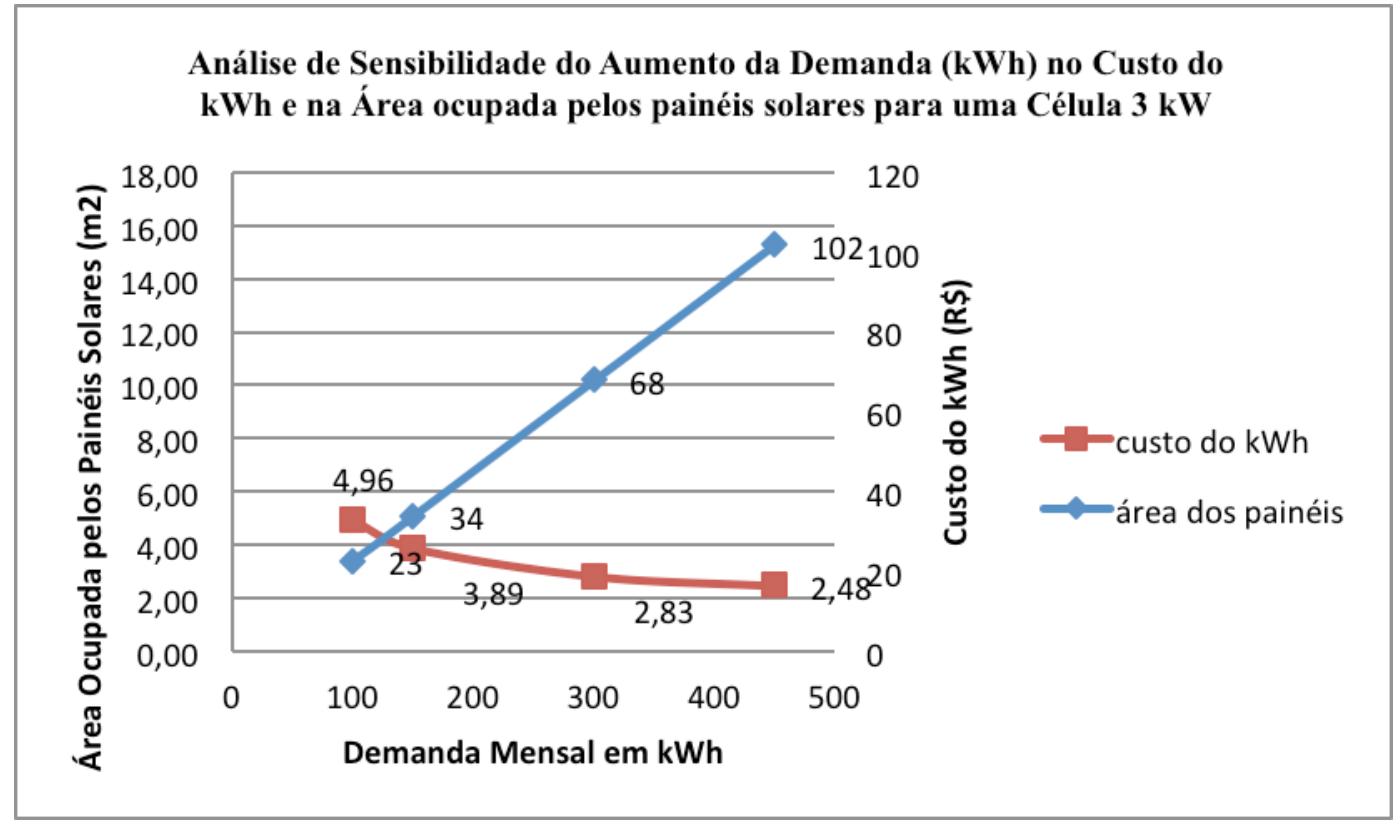

Gráfico 23: Análise de Sensibilidade do Aumento da Demanda (kWh) no Custo do kWh e na Área ocupada pelos painéis solares para uma Célula $3 \mathrm{~kW}$.

Fonte: Elaboração própria.

O gráfico 24 é referente à situação escolhida para o projeto da residência (demanda energética de $450 \mathrm{kWh} / \mathrm{mês}$ com uma célula de $5 \mathrm{~kW}$ de potência). O preço do $\mathrm{kWh}$ sairia a $\$$ 2,95 reais com uma área ocupada de aproximadamente $100 \mathrm{~m}^{2}$ de painéis solares.

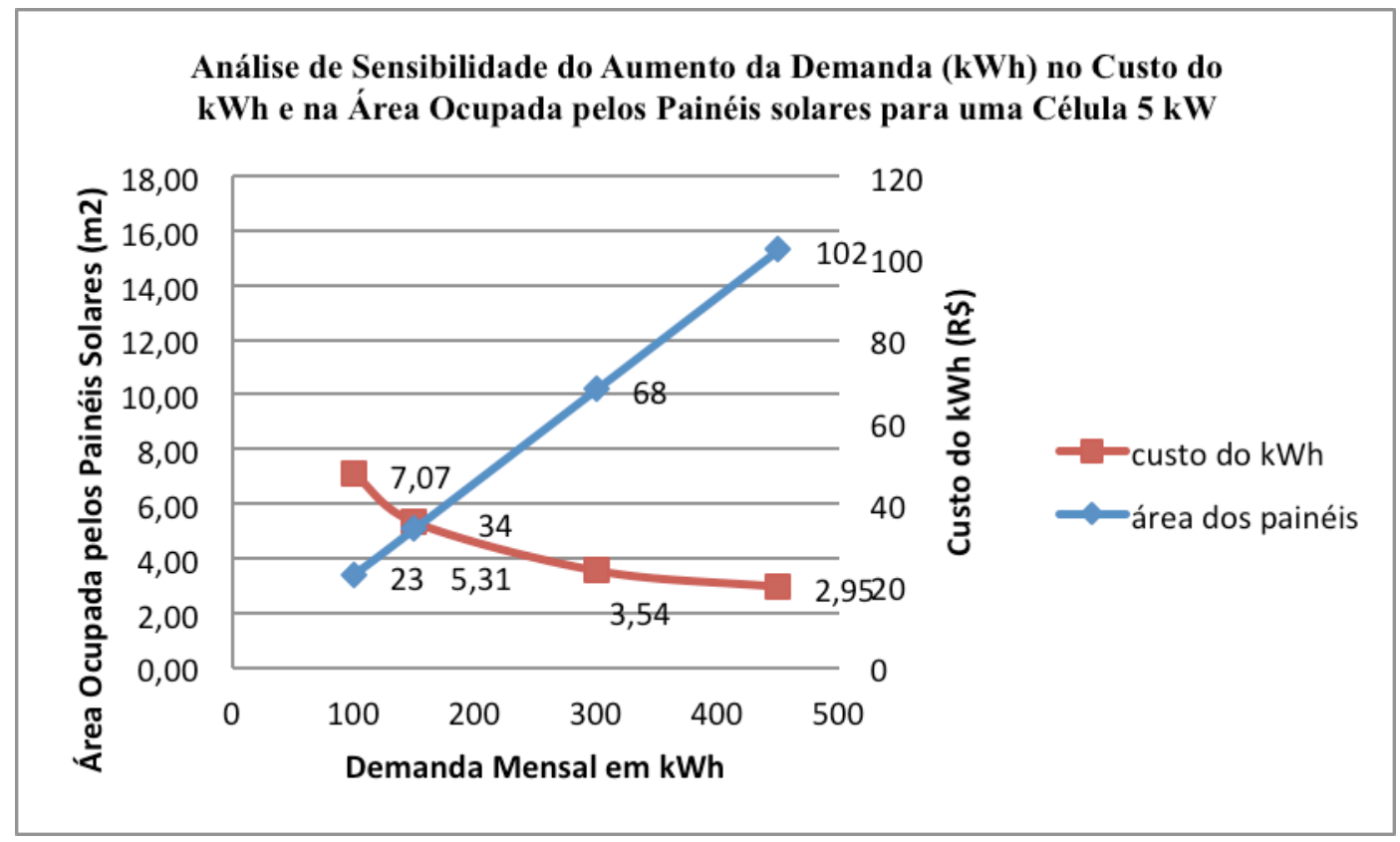

Gráfico 24: Análise de Sensibilidade do Aumento da Demanda (kWh) no Custo do kWh e na Área ocupada pelos painéis solares para uma Célula $5 \mathrm{~kW}$.

Fonte: Elaboração própria. 
A análise foi feita também para as potências de $10 \mathrm{~kW}$ e $15 \mathrm{~kW}$. Nota-se no gráfico $25 \mathrm{e}$ 26 que a área ocupada pelos painéis fotovoltaicos continua a mesma, pois o consumo energético é o mesmo, no entanto o custo do kWh aumenta devido somente ao aumento da potência da célula.

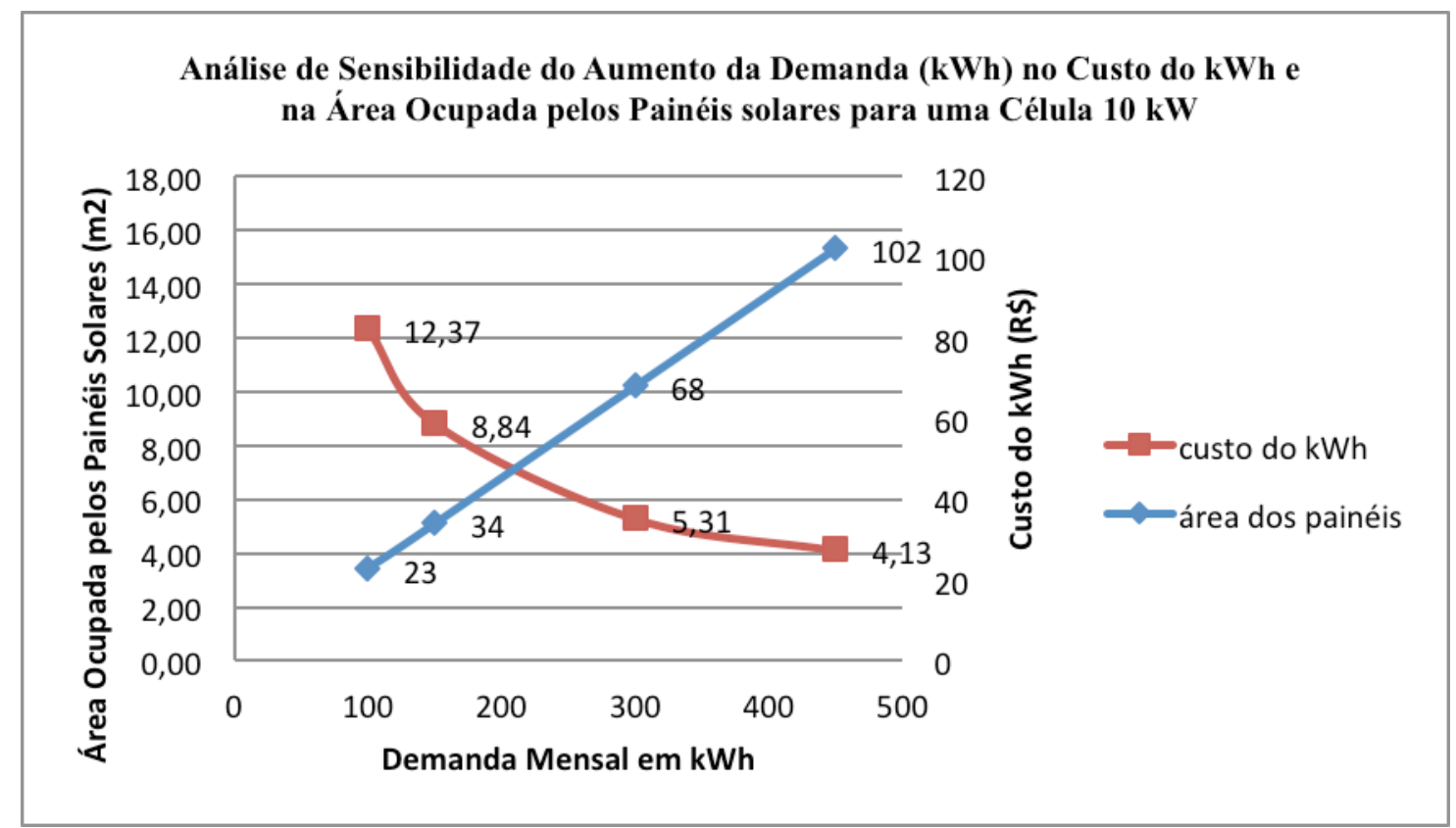

Gráfico 25: Análise de Sensibilidade do Aumento da Demanda (kWh) no Custo do kWh e na Área ocupada pelos painéis solares para uma Célula $10 \mathrm{~kW}$.

Fonte: Elaboração própria.

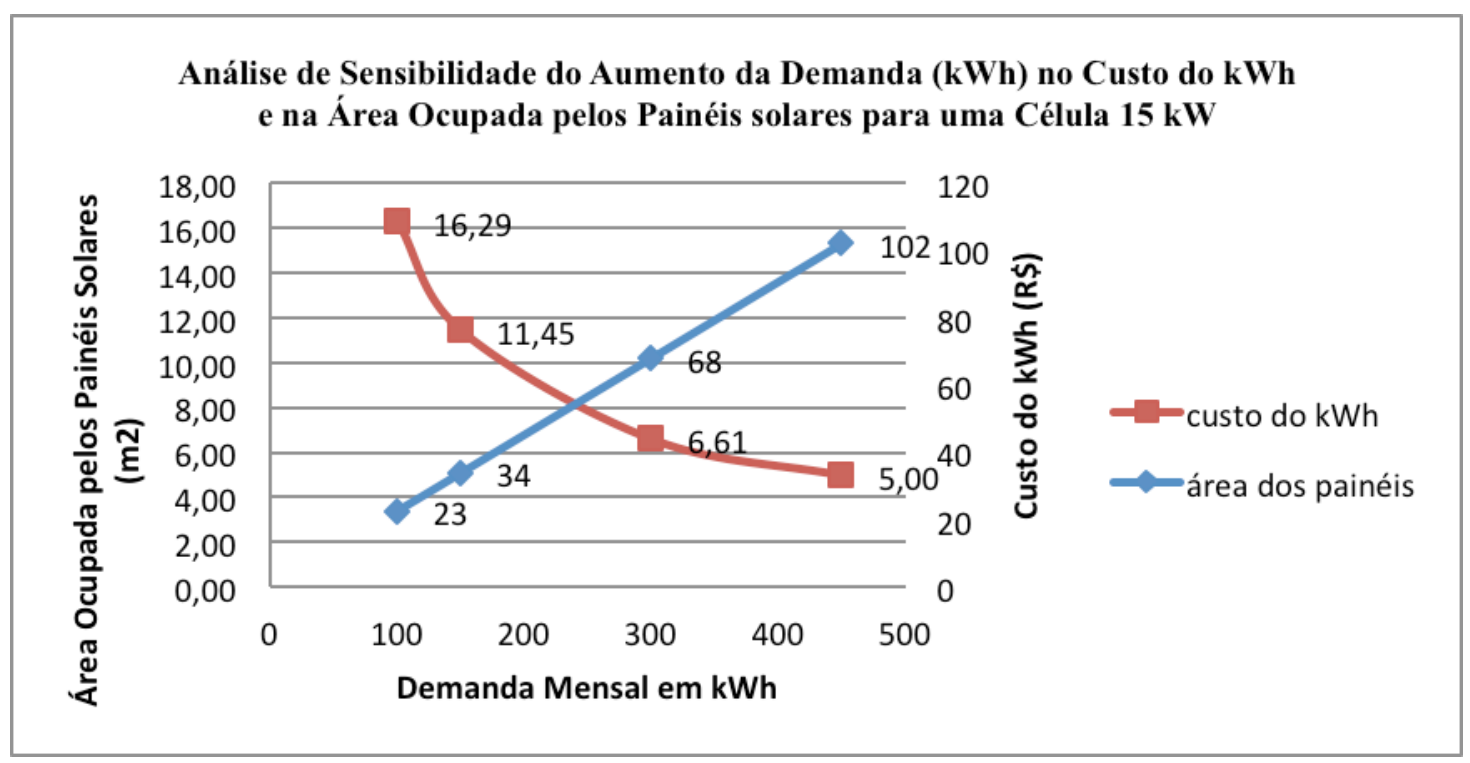

Gráfico 26: Análise de Sensibilidade do Aumento da Demanda (kWh) no Custo do kWh e na Área ocupada pelos painéis solares para uma Célula $15 \mathrm{~kW}$. 
Fonte: Elaboração própria.

O preço do kWh em relação à potência da célula (em watts) é mais alto quando se faz o dimensionamento do sistema prevendo a demanda (consumo energético).

Quando utilizado qualquer das potências estudadas de célula (3, 5, 10 e 15 kW) utilizando sua potência máxima o preço do $\mathrm{kWh}$ é fixo 1,90 como visto anteriormente, e pelo gráfico 25 nota-se que esse preço aumentou pois foi calculado por demanda. Assim cada vez que se aumenta o consumo de energia o preço diminui.

\subsection{ESGUDOS G COMPARAÇÕES EO UMA COMUNIDADE DE 40 CASASS}

Pensando em um cenário de sobra de energia foi feito um gráfico da análise de sensibilidade do aumento da demanda no custo de implantação do sistema e no custo da energia para uma célula de $40 \mathrm{~kW}$ para uma hipotética comunidade isolada.

Muitas regiões brasileiras, como o caso da Região Amazônica, possuem comunidades sendo supridas de forma precária, com intervalos de atendimento que variam de 4 a 8 horas diárias, e outras em que este serviço nem chega a se completar. A principal característica desses municípios e comunidades é o fato de todas estarem desconectadas dos Sistemas Elétricos Interligados, tornando a geração descentralizada sendo a forma de geração mais apropriada e necessária a esse cenário (SILVA \& CAVALIERO, 2001).

Outras características também compartilhadas por essas comunidades são: estarem localizadas às margens dos rios, com acesso limitado quase que exclusivamente a barcos, possuírem baixa densidade populacional e carência de infra-estrutura básica. A geração de energia elétrica em locais com essas características é feita geralmente através de motores a diesel, onde a capacidade nominal instalada varia de acordo com a comunidade. O óleo diesel 
utilizado pode ser subsidiado, pago pela Conta de Consumo de Combustíveis (CCC), ou pago pela própria comunidade (SOUZA, 2000).

As centrais termelétricas a óleo diesel foram sempre apresentadas como a solução para a geração de energia elétrica nas regiões isoladas da Amazônia. Mas a dificuldades encontradas para o transporte do óleo diesel, que é feito através de balsas, e a grande diversidade de fabricantes, são fatores que tornam os custos de operação e manutenção bastante elevados, provocando constantes racionamentos. Outros fatores contrários a essa tecnologia refere-se a queima de combustíveis fósseis, uma vez que existe potencial energético significativo de fontes renováveis na região e o risco de danos ecológicos de graves proporções decorrentes de vazamento de combustíveis nos rios utilizados para transporte do próprio combustível.

A geração de energia elétrica no interior amazonense requer características especiais, principalmente ambientais, por estar situado na Floresta Amazônica, cuja preservação é alvo de constantes debates. Portanto, é fundamental que essas comunidades tirem melhor proveito dos recursos energéticos dessa região, que é onde se encontra a maior parte dos sistemas isolados.

Destaca-se também a importância de se buscar um aumento na participação das fontes de energia renovável, fontes não convencionais com baixos impactos ambientais e uma forma alternativa ao consumo de combustíveis de origem fóssil utilizados (SILVA, 2001). Essa alternativa traria melhoria no suprimento de energia e, em consequência, na qualidade de vida das populações residentes nessas comunidades, aumentando as suas possibilidades de crescimento e desenvolvimento econômico, social e humano, de forma sustentável.

A implantação de sistemas autônomos de geração de energia elétrica é uma forma de suprir as necessidades básicas da população. Contribui para que o uso de máquinas em substituição à força motriz aumente a produção dos produtos agrícolas, bem como produção de frio para conservação de pescado e armazenamento de vacinas em postos de saúde. Com respeito à educação, possibilita também aulas noturnas, solucionando o problema dos jovens, cuja presença no trabalho familiar é imprescindível durante o dia, levando ao abandono escolar. 
A dificuldade de comunicação com o município também pode ser solucionada, especialmente nas questões referentes à saúde.

Pensando nesse cenário optou-se por um conjunto de 40 casas (um quarteirão) onde seriam disponibilizados $1 \mathrm{~kW}$ de potência para cada casa. Esta potência inviabiliza o uso de chuveiros elétricos, destacando-se apenas o uso dos eletrodomésticos mais utilizados como geladeira, televisão, lâmpadas etc. assim a soma das potências desses equipamentos estando ligados ao mesmo tempo não excederia a potência total do sistema de $1 \mathrm{~kW}$.

O próximo gráfico 27 extraído da Tabela em Anexo 7.8. mostra que para uma demanda de $4000 \mathrm{kWh} / \mathrm{mês}$, com cada casa consumindo uma demanda de $100 \mathrm{kWh}$ mensais, o custo de implantação do sistema seria de aproximadamente de 1 milhão de reais, e o custo do kWh seria de 2,74 reais. Nota-se que o valor do kWh já ficou próximo do valor do kWh estimado para comunidades isoladas, como por exemplo na Amazônia, pois o preço do litro do diesel pode chegar a 3,20 reais na cidade de Manaus capital do estado do Amazonas (UOL NOTíCIAS, 2014)

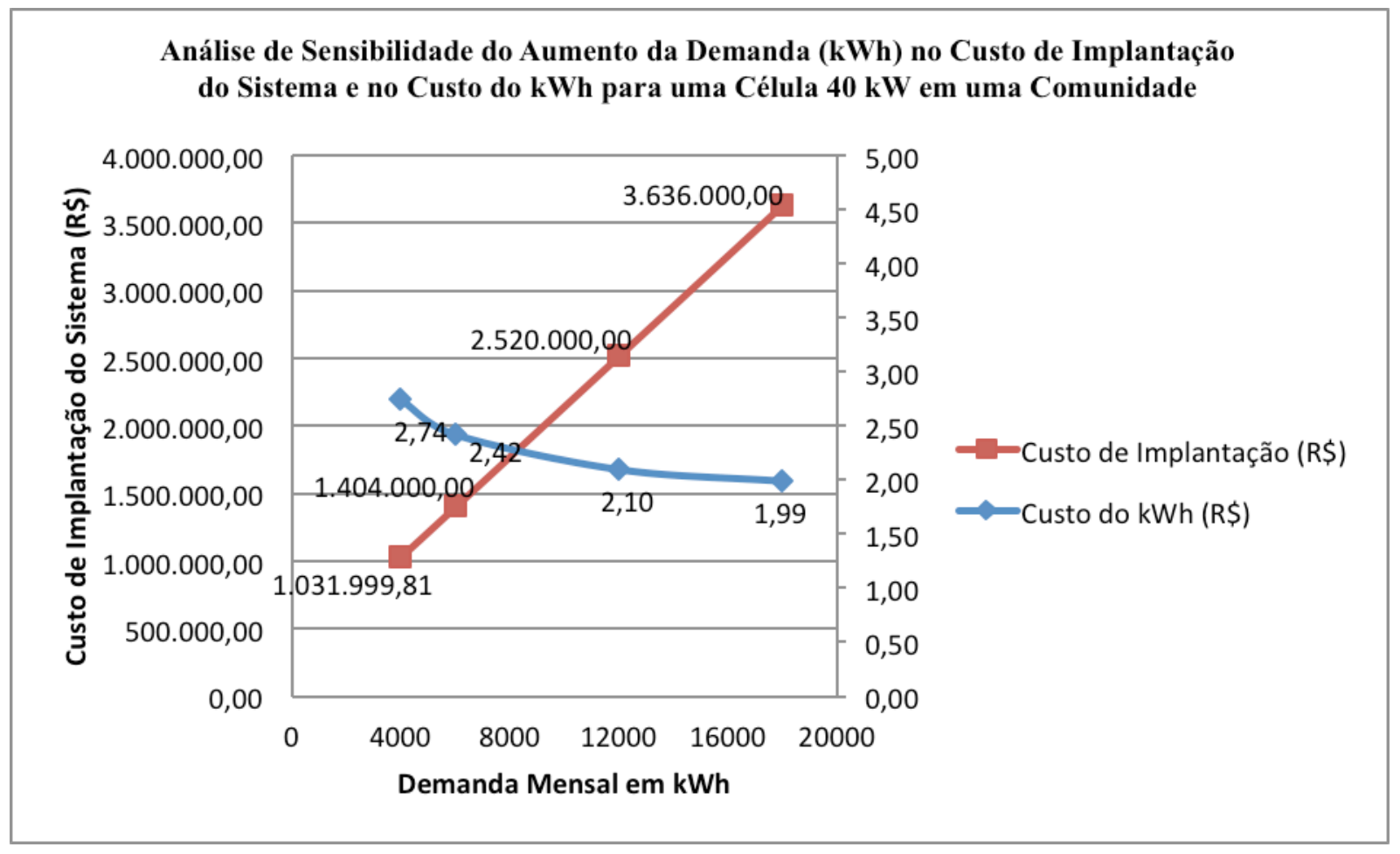

Gráfico 27: Análise de Sensibilidade do Aumento da Demanda (kWh) no Custo de Implantação do Sistema e no Custo do kWh para uma Célula 40 kW em uma Comunidade.

Fonte: Elaboração própria. 


\section{CONCLUSÕES}

A energia solar vem crescendo consideravelmente, tanto no mundo como também no Brasil, e a tendência é que aumente ainda mais nos próximos anos devido à necessidade de expandir a oferta de energia elétrica e a preocupação cada vez maior em reduzir a emissão de gases de efeito estufa associada ao consumo de combustíveis de origem fóssil. Por outro lado, o caráter inconstante da geração solar acaba dificultando a garantia e a continuidade no fornecimento de energia elétrica, levando a um desequilíbrio entre a curva de oferta e demanda de eletricidade. A utilização do hidrogênio eletrolítico como meio armazenador de energia se apresenta como uma solução para o problema descrito. Com este trabalho conclui-se que:

1.Há duas maneiras de dimensionar o sistema de energia elétrica distribuída para uma residência típica, um é levando em consideração a curva da demanda (consumo em $\mathrm{kWh} / \mathrm{mês}$ ) do qual foi encontrado um consumo equivalente a $450 \mathrm{kWh} / \mathrm{mês}$, e outro dimensionamento levando em consideração a potência total em watts requerida por essa residência típica modelo do qual foi estimado uma potência equivalente a $5 \mathrm{~kW}$.

2.Houve esse duplo dimensionamento do sistema devido à diferença do número de painéis fotovoltaicos serem bem menor quando levado em consideração a demanda energética da casa. No caso à área ocupada por número de painéis para a demanda $(\mathrm{kWh})$ foi de aproximadamente $100 \mathrm{~m}^{2}$, e para a potência requerida (W) foi de $800 \mathrm{~m}^{2}$.

3.Notou-se que a o sistema gera muita energia $(\mathrm{kWh})$ para pouca potência $(\mathrm{W})$. Isso quer dizer que a escolha dos equipamentos (eletrodomésticos) fica restrita conforme a soma das suas potências, por exemplo, um micro-ondas tem $1 \mathrm{~kW}$ de potência, se ele estiver ligado já utiliza muita potência total do sistema, caso a energia elétrica da casa seja apenas suprida pela célula combustível (sistema isolado), e fazendo ainda uma comparação, o chuveiro elétrico convencional requer $4 \mathrm{~kW}$ o que comprometeria o emprego do sistema se ele não for interligado a rede, para usar apenas a potência (em watts) da rede convencional. 
4.Por outro lado, o sistema da casa estaria jogando na rede muita energia $(\mathrm{kWh})$ e se tivéssemos um incentivo por leis e normas adequadas estaríamos recebendo o valor em troca. Atualmente a ANEEL pela resolução normativa $n^{\circ}$ 482, de 17 de abril de 2012 apenas tem um sistema de compensação no qual a energia injetada é cedida, por meio de empréstimo gratuito, à distribuidora local e posteriormente compensada com o consumo de energia elétrica ativa dessa mesma unidade consumidora.

5.Quanto ao processo de projeto não houve grandes alterações, apenas a adição de mais um ambiente no programa de necessidades, como se fosse a casa de máquinas onde estão locados a célula a combustível $(1,0 \mathrm{mH} \times 0,8 \mathrm{~mL} \times 0,6 \mathrm{mC})$ o eletrolisador $(0,8 \mathrm{mH} \times 0,6 \mathrm{~mL} \times$ $0,6 \mathrm{mC}$ ) e a mesa de computador para o sistema de controle automático, no entanto esse ambiente necessita das aberturas mínimas para iluminação e ventilação, entradas e saídas com contato direto com uma área reservada para armazenamento de hidrogênio em cilindros. Essa casa de máquinas ficou com 7,15 metros quadrados para comportar o sistema.

6.Outra adição no programa de necessidades foi o local de armazenamento dos cilindros de hidrogênio, que tem que estar dentro das normas de segurança, portanto, local arejado, coberto, protegidos de sol, chuva e orvalho (ferrugem), longe de materiais inflamáveis ou combustíveis, nem junto a fontes de calor; com sinalização do local, com placas de advertência, entre outras. O local escolhido para esse armazenamento foi ao lado da casa de máquinas na área externa da casa com cobertura própria de laje e grade de ferro de proteção para animais e crianças, o local tem 6,0 metros quadrados.

7.O restante do projeto da casa não precisou sofrer alterações para receber o sistema distribuído de energia. Houve a necessidade de adequar o projeto da casa a carta bioclimática (NBR 15220) incorporando as estratégias de projeto que a zona bioclimática 6 implica, zona a que pertence a cidade de Cajobi, de acordo com tamanho e proteção das aberturas, tipo de materiais e técnicas utilizados na parede e cobertura, ventilação cruzada seletiva (somente no verão) e a utilização de vegetação para umidificação no período seco. A implantação da casa foi feita no sentido maior norte/sul onde as áreas de maior permanência ficaram na direção 
norte, e as áreas molhadas na parte oeste, com proteção total das aberturas através da varanda com telhado verde.

8.As adoções das estratégias de conforto ambiental e arquitetura bioclimática, como iluminação e ventilação natural para redução do consumo de energia é imprescindível mesmo fazendo a utilização desse sistema limpo e renovável de energia, pois os custos para a implantação do sistema ficam mais baratos.

9.Em relação aos custos não foi realizado o VLP (valor presente liquido) para cálculo de viabilidade do sistema, pois sabemos que o VLP já é negativo (não há retorno financeiro na implantação do sistema) assim foi feito o cálculo do CAE como ferramenta de análise econômica. O custo de implantação do sistema (para o modelo da casa estipulado com demanda mensal de $450 \mathrm{kWh} /$ mês e célula de $5 \mathrm{~kW}$ ) foi de $\$ 119.700,00$ reais, e o kWh por $\$$ 2,85 reais. O CAE saiu a um valor de 15389,00 ao ano com taxa de $10 \%$.

10. Se a célula de $5 \mathrm{~kW}$ trabalhar full time temos uma produção de energia de $3600 \mathrm{kWh} / \mathrm{mês}$. Como se pode notar sobraria uma grande parte da energia, essa podendo ser vendida para as concessionárias na hora de pico se houvesse uma política de incentivo para isso. Pensando nesse aspecto foi feito um cenário de 40 casas com demanda de energia mensal de 4000 ou 6000, 12000 e 18000 kWh com uma célula de 40 kW (disponibilizando 1 kW para cada casa) onde se chegou há um custo de $\$ 1,99$ reais o $\mathrm{kWh}$. Esse preço é competitivo quando se fala em sistemas de energia para comunidades isoladas. Assim pode-se concluir que o custo do sistema para residências interligadas a rede não é atrativo, porém para comunidades isoladas já se torna viável.

11. Quanto à eficiência do sistema conclui-se que o mais dispendioso é o processo da eletrólise para produção de hidrogênio, necessitando de uma grande quantidade de painéis solares.

A preocupação cada vez maior em preservar o meio ambiente são importantes incentivos à utilização de fontes renováveis de energia, tal como a solar. Da mesma forma, a utilização do hidrogênio como vetor energético começa a ser encarada como uma opção economicamente 
viável, no entanto uma política de incentivo a energia limpa, renovável e distribuída deve ser implantada para que viabilize projetos como este.

\subsection{SUGESGÕES PARA GRABALদ̆OS FUGUROS}

Tendo em vista a dificuldade na obtenção do custo real da energia elétrica produzida a partir de um sistema gerador a diesel de pequeno porte em áreas isoladas, seria importante calcular esses valores levando-se em consideração, dentre outros fatores, o custo do transporte do diesel até essas localidades. Dessa forma haveria maior clareza na comparação econômica entre essa forma de geração e o sistema a hidrogênio solar utilizado neste estudo.

Analisar a viabilidade técnica e econômica da instalação de sistemas hidrogênio solar nos laboratórios de informática do IAU/USP. A autonomia do sistema depende das cargas elétricas (equipamentos e lâmpadas) que serão mantidas durante o período que se deseja. No caso de falta de energia elétrica o sistema automaticamente entra em funcionamento, mantendo os equipamentos e lâmpadas ativos. Outra vantagem significativa é a economia de energia elétrica, pois quando o sistema identifica a sobra de energia produzida pelo sistema hidrogênio solar, a energia elétrica que continua sendo gerada durante o dia, poderá ser inserida na rede e utilizada para consumo, reduzindo a energia elétrica consumida da rede pública. 


\section{REFERÊnCIAS BIBLIOGRÁFICÁS}

AGNALDO, J. S.; BASTOS, J. B. V.; CRESSONI, J. C.; VISWANATHAN, G. M. Células solares de TiO2 sensibilizado por corante. Revista Brasileira de Ensino de Física. Porto Alegre, v. 28 , n. 1, p. 77-84, 2006.

AREA FRANCE, 2014. Products. Disponível em: <http://www.areafranceram.com/it.> Acesso em: 14 mai. 2014.

ANEEL - AGÊNCIA NACIONAL DE ENERGIA ELÉTRICA. Atlas de energia elétrica. $2^{\circ}$ Edição. Disponível em: <http://www3.aneel.gov.br/atlas/atlas_2edicao/download.htm>. Acesso em: 30 set. 2013.

Universalização - Planos 2005-2008. Divulga a $2^{\mathrm{a}}$ Parte do Plano de Universalização de Energia Elétrica - Metas para o período 2005-2008. Disponível em: <http://www.aneel.gov.br/440.htm>. Acesso em: 21 de Nov. 2012.

ANDREAZZI, M. A. R. Impactos de hidrelétricas para a saúde na Amazônia. Rio de Janeiro: Universidade Estadual do Rio de Janeiro. Série Estudos em Saúde Coletiva, n. 78, 1993.

ALEMANHA, EEG. Renewable Energy Sources Act. In: Federal Law Gazette n.40, Bonn, Germany. Disponível em: <www.bmu.de/english/renewable_energy/doc/6465.php> Acesso em: 11 Mar. 2012.

ARAÚJO, G. M. Segurança na armazenagem, manuseio e transporte de produtos perigosos: Gerenciamento de emergência química. São Paulo: Edgar Blücher, 2005.

ARAÚJO, J. S. Almoxarifado: administração e organização. 7 ed. São Paulo: Atlas, 1975.

ASSOCIAÇÃO BRASILEIRA DE NORMAS TÉCNICAS. NBR 5413: Iluminação de Interiores. Rio de Janeiro, 1992.

NBR 15220: Desempenho térmico de edificações - parte 1: definições, símbolos e unidades. Rio de Janeiro, 2005.

2006.

NBR10899: Energia solar fotovoltaica - Terminologia. Rio de Janeiro, 
NBR 15575: Edificações habitacionais de até cinco pavimentos -

Desempenho. Rio de Janeiro, 2008.

Brasil.

(2008). NBR 11704: Sistemas fotovoltaicos - Classificação. Rio de Janeiro,

ASSOCIAÇÃO BRASILEIRA DE INSTITUIÇÕES FILANTRÓPICAS DE COMBATE AO

CÂNCER. Notícias. Disponível em: <http://www.abifcc.org.br/oldnews/noti19072004.html>. Acesso em: 14 Mai. 2012.

A L. M. ALVAREZ. Uso racional e eficiente de energia elétrica: metodologia para a determinação dos potenciais de conservação de usos finais em instituições de ensino e similares. Dissertação (mestrado) - Escola Politécnica, São Paulo, 1998.

AMERICAN SOCIETY OF HEATING, REFRIGERATING AND AIR CONDITIONING ENGINEERS, INC. Thermal Environmental Conditions for Human Occupancy, ASHRAE Standard 55-1992. Atlanta, EUA, 1992.

BALCOMB, D. The coming revolution in building design. In: Environmentally Friendly Cities Proceedings of PLEA 98. Lisbon: James \& James Science Publishers Ltd. June, 33-37 p. 1998.

BARBIR, F. PEM Electrolysis for Production of Hydrogen from Renewable Energy Sources.

Solar Energy. V. 78, N. 5, P.661 a 664, Maio, 2005.

BARBOSA, M. J. Uma metodologia para especificar e avaliar e desempenho térmico em edificações residenciais unifamiliares. Tese (Doutorado) Universidade Federal de Santa Catarina, Florianópolis, 1997.

BARROS, E. V. D. A matriz energética mundial e a competitividade das nações: bases de uma nova geopolítica. Engevista, São Paulo. Ano Jun./ 2007, v.9, p.47-56, 2007.

BARROSO-KRAUSE, C. Coberturas, conforto higrotérmico, edificações: ponderações e propostas para clima tropical úmido em situação de verão. Dissertação (Mestrado) Universidade Federal do Rio de Janeiro. Rio de Janeiro. 1989.

Trabalho elaborado no âmbito do PROCEL EDIFICA - Eficiência Energética em Edificações. Desempenho Térmico e Eficiência Energética em Edificações. Rio de Janeiro, agosto de 2011.

BERMANN, C. Energia no Brasil: para quê? Para quem? Crise e alternativas para um país sustentável. São Paulo, Ed. Livraria da Física, 2001. 
BITTENCOURT, L. Ventilation as a cooling resource for warm humid climates: An investigation on perforated block wall geometry to improve ventilation inside low-rise buildings. Tese (Doutorado). Architectural Association Graduate School, Londres, 1993.

BP. Statistical Review of World Energy. Disponível em: <www.bp.com/statisticalreview> Acesso em: 15 jan. 2012.

BOGO, A; PIETROBON, C. E.; BARBOSA, M. J.; GOULART, S.; PITTA, T. Bioclimatologia aplicada ao projeto de edificações visando conforto térmico. Florianópolis: NPC: UFSC, 1994.

BRAGA, A. F. B.; MOREIRA, S. P.; ZAMPIERI, P. R.; BACCHIN, J. M. G.; MEI, P. R. New processes for the production of solar-grade polycrystalline silicon: A review. Solar Energy Materials and Solar Cells. Issue 4, v.92, p.418-424, 2008.

BRASIL. MINISTÉRIO DE MINAS E ENERGIA. Balanço Energético Nacional 2011 Ano base 2010. EPE. Rio de Janeiro, 2011.

Secretaria de Planejamento e Desenvolvimento Energético. Portaria $n^{\circ} 36$ de 26/11/2008, In: Diário Oficial da União, n. 232, Seção 2, pp. 56, 28 de novembro de 2008, ISSN 1677-7050. 2008.

CAAMAÑO, E.; THORNYCROFT, J.; MOOR, H. D.; COBBEN, S.; JANTSCH, M.; ERGE, T.; LAUKAMP, H.; SUNA, D.; GAIDDON, B. State-of-the-art on dispersed PV power generation: Publications review on the impacts of PV Distributed Generation and Electricity networks. PV Upscale. Issue PV in Urban Policies- Strategic and Comprehensive Approach for Longterm Expansion, 2007.

CALLON, M. Society in the Making: The Study of Technology as a Tool forSociological Analysis. The Social Construction of Technological Systems. London, England, The MIT Press. 1987.

Some Elements of a Sociology of Translation: Domestication of theScallops and the Fisherman of St Brieuc Bay. 1986.

CANDIDO, C. M.; BITTENCOURT, L. S.; BATISTA, J. O.; LIMA, L. M. Ventilação natural em edificações escolares: avaliação da altura de captadores de vento. In: X Encontro Nacional de Tecnologia do Ambiente Construído, Anais... 19 - 23 abril, São Paulo, PP. 371-379.

CARVALHO, C. B. Avaliação crítica do planejamento energético de longo prazo no Brasil, com ênfase no tratamento das incertezas e descentralização do processo. UNICAMP, Campinas, SP, 2005. 
CASTAÑER, L.; MAS, A. (1985). Consideraciones sobre el diseño de sistemas fotovoltaicos. Energia Solar Fotovoltaica. Série Mundo Electrónico Barcelona. Marcombo Boixareu Editores. p. 158-162.

CENTRO NACIONAL DE REFERÊNCIA EM ENERGIA DO HIDROGÊNIO - CENEH.

Publicações. Disponível em: <http://www.ifi.unicamp.br/ceneh/> Acesso em: 07 Jul. 2014.

CENTRO DE REFERÊNCIA PARA ENERGIA SOLAR E EÓLICA SÉRGIO DE SALVO BRITO CRESESB. Energia Eólica Princípios e Aplicações. 1999.

CENTRO DE GESTÃO E ESTUDOS ESTRATÉGICOS (CGEE) Secretaria Técnica do Fundo Setorial de Energia. Programa brasileiro de células a combustível. Rio de Janeiro; 2002. (Proposta para o Programa coordenada pelo CGEE).

CEPAGRI - CENTRO DE PESQUISAS METEREOLOGICAS E CLIMATICAS APLICADAS A AGRICULTURA. Publicações. Disponível em: <http://www.cpa.unicamp.br/> Acesso em: 12. Jun. 2012.

CHIVELET, N. M. Técnicas de Vedação Fotovoltaica na Arquitetura. Porto Alegre, Bookman. 2010.

CONTADINI F. P \& D e o estado da arte de células a combustível na América do Norte. Apresentada ao Workshop Internacional de Células a Combustível no Centro de Convenção da UNICAMP; 2002 out 31, Campinas. Disponível em: < http://www.ifi.unicamp.br/ceneh > Acesso em: 12 out. 2013.

CORBELLA, O., YANNAS, S. Em Busca de uma Arquitetura Sustentável para os Trópicos. Rio de Janeiro, Revan. 2003.

CROS, S., MAYER, D., WALD, L. The Availability of Irradiation Data. IEA-PVPS T2-04, 2004.

CRUZ, H. P. Geração de energia elétrica com óleo vegetal de plantas nativas como fator de desenvolvimento na Amazônia - estudo de caso: Região do Médio Juruá no Município de Carauari. Dissertação (Mestrado) Universidade de Brasília, Brasília 2005.

DGS. Planning and installing photovoltaic systems: a guide for installers, architects, and engineers. Earthscan. London, 2008.

DI TRAPANO, P. e BASTOS, L.E.G. Sustentabilidade e Forma. Cadernos do PROARQ/ UFRJ/ Programa de Pós-Graduação em Arquitetura da Universidade Federal do Rio de Janeiro. V. 09. Rio de Janeiro: UFRJ/ PRAORQ, dez 2005. 
DOE - UNITED STATES DEPARTMENT OF ENERGY. A National Vision of America's Transition to a Hydrogen Economy - To 2030 and Beyond, February 2002. Disponível em:<http://www.eere.energy.gov/hydrogenandfuelcells>. Acesso em: 12 Maio 2012.

DORNELLES, K. A.; Absortância solar de superfícies opacas: conceitos, métodos de determinação e base de dados para tintas imobiliárias. 2008. 135 p. Tese (Doutorado) Faculdade de Engenharia Civil, Arquitetura e Urbanismo, Universidade Estadual de Campinas, Campinas, 2008.

ELETROBRÁS. Eletronuclear. Disponível em <http://www.eletronuclear.gov.br/> acesso em: març. 2012.

Plano de operação 2006 - sistemas isolados. Rio de Janeiro: Eletrobrás, Diretoria de Engenharia - Departamento de Sistemas Isolados e Combustíveis - DES, Grupo Técnico Operacional da Região Norte - Gton, 105 p. 2005.

ENERGIA SOLAR RESIDENCIAL. Produtos. Disponível em:

<http://energiasolarresidencial.org/energia-solar-fotovoltaica> .Acesso em: 14 maio 2014.

EPE - EMPRESA DE PESQUISA ENERGÉTICA, 2011. Boletins. Disponível em: $<$ http://www.epe.gov.br/imprensa/PressReleases/20110606_1.pdf>. Acesso em: 07 jun. 2012.

EPIA; GREENPEACE. (2008). Solar Generation V - 2008 Eletricidad solar para más de mil millones de personas y dos millones de puestos de trabajo para el año 2020. Disponível em: <http://www.asif.org/files/Solar_generation_Spanish_V_2 008.pdf >. Acesso em: 15 abr. 2012.

FANGER, P. O. Thermal Comfort. New York, McGraw-Hill Book Company. 1970.

FAPESP. Divulgação cientifica. Competência da Unitech. n. 70, p. 76-77, nov.-dez. 2001.

Disponível em: < http://www.revistapesquisa.fapesp.br/?art=1629\&bd(...)>. Acesso em: 17 maio 2011.

FAPESP REVISTA ONLINE. Cardápio Energético. Edição Impressa n. 157. Março de 2009. Disponível em: <http://revistapesquisa.fapesp.br/?art=3814\&bd=1\&pg=4\&lg=>. Acesso em: 25 maio 2011.

FEARNSIDE, P. M., Greenhouse-gas emissions from Amazonian hydroelectric reservoirs: the example of Brazil's Tucuruí Dam as compared to fossil fuel alternatives. Environmental Converservation 24, p. 64-75. 1997.

FERREIRA, P. P. Análise da viabilidade de sistemas de armazenamento de energia elétrica na forma de hidrogênio utilizando células a combustível. Campinas, SP, 2008. 
FRAINDENRAICH, N. Tecnologia Solar no Brasil. Os próximos 20 anos. In: Sustentabilidade na geração e uso de energia no Brasil: os próximos vinte anos. Campinas, SP: UNICAMP, 2002.

FRAINDENRAICH, N.; LYRA, F. Energia Solar: Fundamentos e Tecnologias de Conversão Heliotermoelétrica e Fotovoltaica. p. 423 - 436. 1995.

FRIBERG, R. Int. J. A photovoltaic solar-hydrogen plans for rural electrification in India. Hydrogen Energy, v.18, n. 10, p. 853-882, 1993.

FROTA, A.B.; SCHIFFER, S.R. Manual de conforto térmico. São Paulo. Studio Nobel. 2002.

FUEL CELLS 2000. Publicações. Disponível em: <http://www.fuelcells.org> Acesso em: 13 Mar. 2013.

FURLAN, A. Analise corporativa de sistemas de armazenamento de energia elétrica fotovoltaica por meio de baterias e hidrogênio em localidades isoladas da região amazônica. Dissertação (mestrado). Unicamp, campinas. 2008.

FURLANETTO, C.; POSSAMAI, O. Uso da Energia Elétrica no Ambiente Residencial; In: Encontro Nacional de Engenharia de Produção - ENEGEP. 2001. Salvador. Anais. 2001.

GARCÍA, Antonio González. Hydrogen and Fuel Cell Activities in Spain.In: European Hydrogen Energy Conference, 2003, Grenoble, September 2-5th, 2003.

GARCIA-CONDE, A G. e ROSA, F. Solar hydrogen production: a spanish experience. Internacional Journal Hydrogen Energy, N.18 V.12 P. 995-1000, 1992.

GALLI, S, STEFANONI, M. Development of a solar hydrogen cycle in italy. Internacional Journal Hydrogen Energy, N.22 V.5 P. 453-458, 1997.

GLÖCKNER, R. Hydrogems - hydrogen energy models. In: Proceedings of WHEC 2002 - 14th World Hydrogen energy Conference, Montreal, 2002.

GIVONI, B. Man, Climate and Architecture. Applied Science Publishers Ltd. London. 1976.

Man, climate and architecture. Applied science publishers. Londres, 1969.

Performance and applicability of passive and low-energy cooling systems. Energy and Buildings. N. 17, p. 14-25, 1991. 
Comfort climate analysis and building design guidelines. Energy and Buildings n. 18, p. 11-23, 1992.

GLOBO. Noticias. Disponivel em <:http://g1.globo.com/economia-enegocios/noticia/2010/04/belo-monte-sera-hidreletrica-menos-produtiva-e-mais-cara-dizemtecnicos.html > Acesso em: 10 març. de 2012.

GOOGLE EARTH MAPS. Disponivel em:< http/googlemaps.com> Acesso em: 30 Ago. 2011.

GRAY, K.; FINSTER, M. The Urban Heat Island, Photochemical Smog, and Chicago: Local Features of the Problem and Solution. Evanston: Department of Civil Engineering, Northwestern University, Submitted to Atmospheric Pollution Prevention Division, U.S. Environmental Protection Agency. 2013.

GREEN, M. A. Recent developments in photovoltaics. Solar Energy. Issue 1-3, v.76, p.3-8. 2004.

HIRSCHFELD, H. Engenharia econômica e análise de custos: aplicações práticas para economistas, engenheiros, analistas de investimentos e administradores. 7 ed. São Paulo Atlas, 2000.

HOPKINSON, R. G. Iluminação Natural. Fundação Calouste Gulbenkian. $2^{\circ}$ ed. Trad. De António Sarmento Lobato de Faria. 1966.

HOPKINSON, R.G. \& KAY, L.D. The light of building. Faber and Faber Ltd, London, 1969.

IBGE PNAD. Pesquisa Nacional por Amostra de Domicílios: síntese de Indicadores 2010. Instituto Brasileiro de Geografia e Estatística. Rio de Janeiro, 2010.

IPCC. Intergovernmental panel on climate change - Climate Change 2007: the scientific basis. Paris, 2007.

INEE. O que é geração distribuída? Disponível em <http//:www.inee.org.br> Acesso em: 5 dez. 2012.

INMET. Normais Climatológicas - 1931 a 1990. Disponível em: <http://www.inmet.gov.br/>. Acesso em: 12 jan. 2012.

IVY, J. Summary of Electrolytic Hydrogen Production - Milestone Completion Report. NREL - National Renewable Energy Laboratory. 2008. Disponível em:<http://www.nrel.gov/docs/fy04osti/36734.pdf> acesso em: 12 fev. 2012. 
JUNK, W. J.; MELLO, J. N. Impactos ecológicos das represas hidrelétricas na bacia amazônica brasileira. In: Homem e Natureza na Amazônia. Tübinger Geographische Studien 95, 1987, p. 367-358.

KELLEY, J.H.; LAUMANN, E.A. Hydrogen tomorrow: demands e technology requeriments. Report of the NASA hydrogen energy systems technology study. P 1-142, NASA, EUA, 1975.

KOENIGSBERGER, INGERSOLL, SZOKOLAY, MAYHEW. Viviendas y edificios en zonas cálidas y tropicales. Madrid, Ed. Paraninfo. 1977.

KYOCERA, 2014. Produtos. Disponível em: <http://www.kyocerasolar.com.br/>. Acesso em: mai.2014.

LAMBERTZ, R. et al. Eficiência Energética na Arquitetura. São Paulo Editora PW. 1997.

Casa eficiente: consumo e geração de energia. Florianópolis: UFSC/ LabEEE; v. 2, 76 p. 2010.

LASNIER, F.; ANG, T. Photovoltaic engineering handbook. Adam Higler, Princeton Search PubMed. 1990.

LINARD, M. et al. Tecnologia de células a combustível. Química Nova, 23(4) São Paulo - SP. 1999.

LINARDI, M.; ARICÓ, E.A. Células a combustível de baixa potência para aplicações estacionárias. IPEN, 2001.

LINARDI M. Células a combustível SOFC e PEMFC de baixa potência para geração de energia elétrica distribuída. In: Apresentada ao Workshop Internacional de Células a Combustível no Centro de Convenção da UNICAMP; 2002 out 31, Campinas. Disponível em: < http://www.ifi.unicamp.br/ceneh>. Acesso em: 15 de jan.de 2012.

LORENZI,B. R. Em busca de alternativas energéticas: estudo sobre as células a combustíveis no Brasil. Dissertação (mestrado) Ufscar, São Carlos. 2012.

MAYCOCK, P. D. Photovoltaics: Sunlight to Electricity in One Step. Andover, Brick House. 222 p. 1981.

MASCARÓ, L.R. Energia na edificação: estratégia para minimizar seu consumo. São Paulo: Projeto. 1991. 
MATOS, M. Investimentos financeiros em projetos de célula a combustível e hidrogênio no Brasil. UNICAMP, Campinas, SP, 2009.

MINISTÉRIO DA CIÊNCIA E TECNOLOGIA - MCT. Programa Brasileiro de Sistemas de Células a Combustível (PROCaC). 2002.

MURRAY, J. P.; FLAMANT, G.; ROOS, C. J. Silicon and solar-grade silicon production by solar dissociation of Si3N4. Solar Energy. Issue 10, v.80, p.1349-1354, 2006.

NETO, Emilio Hoffmann Gomes. Atividades com Células a Combustível e Hidrogênio no Brasil. In: Brasil H2 Fuel Cell Expo/Seminar, 1., 2007, Curitiba. Disponível em:

<http://www.portalh2.com.br/prtlh2/images/artigos/a32.pdf>. Acesso em: 13 set. 2010.

OLGYAY, V. Design with climate. Princeton university press, Princeton, 1963.

Arquitectura y clima: manual de diseño bioclimatico para arquitectos y urbanistas. Gustavo Gili. Barcelona, 1998.

PAULA, C. P. Geração Distribuída e Cogeração no Setor Elétrico: Avaliação Sistêmica de um Plano de Inserção Incentivada. Dissertação (mestrado) Programa Interunidades de Pós-graduação em Energia PIPGE/USP, Universidade de São Paulo, São Paulo, 313 p. 2004.

PEREIRA, E. B.; MARTINS, F. R.; ABREU, S. L. D.; RUTHER, R. Atlas Brasileiro de Energia Solar: INPE. São José dos Campos, 2006.

PEREIRA, N. M. O fim do petróleo e outros mitos. ComCiencia, N. 38, dez. 02/jan. 03. In: ROHRICH, S., Descarbonização do Regime Energético Dominante: Perspectivas para a economia do hidrogênio no Brasil. UNICAMP, Campinas, SP, 2008.

PINTO, C.F. Em busca de uma arquitetura sustável: o uso de fontes alternativas de energia. Disserataçao (mestrado) Programa de Pos graduação em arquitetura e urbanismo, EESC, Universidade de São Paulo, 223 p. 2009.

PIRES, F.; BUENO F. Política Energética para o Brasil: propostas para o crescimento sustentável. Rio de Janeiro, Nova Fronteira, 2006.

PLUGPOWER. Fuel Cell products for backup power. Disponível em: <www. plugpower.com.> Acesso em: 15 set. 2012.

POPOV, L.A. Architecture as Social Design: the social nature of design objects and the implications for the profession. The Journal of Design Research. Volume 2-2002. Delf University Press. 20012. 
PROTON ENERGY. Products. Disponível em: <http://protononsite.com/company/about.html>. Acesso em: 12 mai. 2014.

PROCEL - PROGRAMA NACIONAL DE CONSERVAÇÃO DE ENERGIA ELÉTRICA. Diversos autores (2001). Orientações Gerais para Conservação de Energia Elétrica em Prédios Públicos. $1^{a}$ edição, abril de 2001.

Eficiência Energética nas Edificações. Publicações. Disponível em: <http://www.procelinfo.com.br/data/Pages/LUMIS623FE2A5ITEMIDC46EOFFDBD124A019 7D2587926254722LUMISADMIN1PTBRIE.htm> Acesso em: 15 mai. 2011.

SINFHA -Sistema de Informação de Posses e Hábitos de Uso de Aparelhos Elétricos. Disponível em: http://www.procelinfo.com.br/> Acesso em: 14 Jun. 2014.

RICHARDS, I. Hamzah \& Yeang: Ecology of the Sky. Australia. The Images Plublishing Group, 2001.

RIFKIN, J. A Economia do Hidrogênio. São Paulo: M.Books, 2003.

ROCHA, B. P.; SILVA, I. O. S. Energia para o desenvolvimento sustentável da Amazônia. In: MELLO, A.F. (Org.). O futuro da Amazônia: dilemas, oportunidades e desafios no limiar do século XXI. Belém: Editora Universitária da UFPa, p.87-100. 2002.

ROHLES, F. H. Temperature or Temperament: A Psychologist looks at Thermal Comfort. ASHRAE Transactions. Atlanta: v. 86, n. 1, p. 541-554, 1980.

ROHRICH, S. Descarbonização do Regime Energético Dominante: Perspectivas para a economia do hidrogênio no Brasil. UNICAMP, Campinas, SP, 2008.

ROMERO, M. A. B. A arquitetura bioclimática do espaço público.ed. UNB. Coleção arquitetura e urbanismo: Brasília, 2001.

ROMERO, M.; GONÇALVES, C. G.; GUGLIELMETTI, A. Edifício Birmann 21: um estudo sobre eficiência energética. Disponível em <http://www.tecto.com.br>. Acesso em 14 dez. de 2012.

RORIZ, M.; GHISI, E.; LAMBERTS, R. Uma proposta de norma técnica brasileira sobre o desempenho térmico de habitações populares. In: V Encontro Nacional de Conforto no Ambiente Construído \& II Encontro Latino Americano de Conforto no Ambiente Construído. Fortaleza, 1999. Artigo Técnico. 
ROSA V. Energia elétrica renovável em pequenas comunidades no Brasil: em busca de um modelo sustentável Tese (Doutorado) Universidade de Brasília Centro de desenvolvimento sustentável. Brasília. 2007.

RÜTHER, R. Experiences and operational results of the first grid-connected, building integrated, thin film photovoltaic installation in Brazil. In: Proceedings of the 2nd World Conference on Photovoltaic Solar Energy Conversion. p. 2655-2658. Vienna, Áustria. 1998.

Panorama Atual da Utilização da Energia Solar Fotovoltaica e o Trabalho do Labsolar nesta Área. Laboratório de Energia Solar (LABSOLAR), Departamento de Engenharia Mecânica, Universidade Federal de Santa Catarina, Florianópolis, SC. 1999.

Edifícios solares fotovoltaicos: o potencial da geração solar fotovoltaica integrada a edificações urbanas e interligada à rede elétrica pública do Brasil. Editora UFSC / LABSOLAR, Florianópolis, SC. 2004.

RÜTHER, R. et al. Avaliação do impacto da geração distribuída utilizando sistemas solares fotovoltaicos integrados à rede de distribuição. 2005. Disponível em:

<http://www.unisinos.br/_diversos/revistas/estudos_tecnologicos/index.php?e=1\&s=9\&a=3> Acesso em: 15 nov. de 2011.

RÜTHER, R. et al. Programa de Telhados Solares Fotovoltaicos Conectados à Rede Elétrica Pública no Brasil. In: XII Encontro Nacional de Tecnologia do Ambiente Construído. Geração de Valor no Ambiente Construído: Inovação e Sustentabilidade. 7 a 10 outubro de 2008. Fortaleza/CE. ISBN: 978-85-89478-27-4. 2008.

RÜTHER, R.; VIANA, T. S.; SALAMONI, I.T. Reliability and Long-term Performance of the First Grid-connected, Building-integrated, Amorphous Silicon PV Installation in Brazil. In: Proceedings of the 33rd IEEE Photovoltaic Specialists Conference. San Diego, CA, USA. 2008.

SANYO. Products. Disponível em:<http://us.sanyo.com> Acesso em: 16 Abr. 20013.

SÉRIE ARQUITETOS BRASILEIROS. João Figueiras Lima. Lelé. Editora Blau e Instituto Lina Bo e PM Bardi. Lisboa, 1999.

SILVA, E. P. Introdução à Tecnologia e Economia do Hidrogênio. Campinas: Editora da UNICAMP, 1991. 204p.

Normas de Segurança para Manuseio e Utilização de Cilindros Pressurizados Contendo Hidrogênio. Campinas: Emopi Gráfica e Editora Ltda., 1992. 22 p. 
SILVA, E. P. et al . Implementation of a photovoltaic/electrolyzer/fuel cell autonomous system. International Congress on distributed generation and energy in rural areas. AGRENER GD 2006: 6. Congresso internacional sobre geração distribuída e energia no meio rural, Campinas, SP (Brasil), 6-8 Jun 2006. Disponível em <www.osti.gov/servlets/purl/21403748-I5hVJ6> Acesso em: 10 març. 2012.

SOUZA; S. N. M. Aproveitamento da Energia Hidroelétrica Secundária para Produção de Hidrogênio Eletrolítico. Tese (Doutorado) - Faculdade de Engenharia Mecânica. 192 p. Unicamp, Campinas, 1998.

SOUZA, S.N.M.; SILVA, E.P. Integração da energia hidroelétrica secundaria e do gás natural por meio de hidrogênio. II Congresso Brasileiro de planejamento energético, Unicamp, Campinas - SP, Brasil, dezembro de 1994.

TAVARES, S. F. Metodologia de análise do ciclo de vida energético de Edificações residenciais brasileiras. Tese (Doutorado) - Programa de pós-graduação em engenharia civil. Universidade Federal de Canta Catarina, Florianópolis, Brasil, abril de 2006.

TREBLE, F.C. Generating electricity from the sun. Oxford, Pergamon. P. 293. 1991.

WINROCK INTERNATIONAL - BRAZIL. Trade guide on renewable energy in Brazil. Outubro 2002.

WHITE MARTINS. Ficha de informações de segurança de produtos químicos. 2006.

Disponível em: <http://www.proplad.ufu.br/sites/proplad.ufu.br/files/GasesEsp-HidrogenioFISPQ-04604.pdf>. Acesso em: 15 abr. 2014.

ULLEBERG, O. The importance of control strategies in PV-hydrogen systems. Solar Energy. V.76, 2004.

UNITECH Ltda. Produtos. Disponível em: <http//www.unitechenergia.com.br> Acesso em: 15 jun. 2014.

UTC Fuel Cells. About Fuel Cells. Disponível em:

http://www.utcfuelcells.com/fuelcell/how_fl.shtml. Acesso em: 18 nov. 2011.

VARELLA, F. K. O. M. Estimativa do índice de nacionalização dos sistemas fotovoltaicos

no Brasil. Tese (Doutorado). Universidade Estadual de Campinas, UNICAMP. 148 p. 2009.

VERGARA, L.G. Análise das condições de conforto térmico de trabalhadores da unidade de terapia intensiva do hospital universitário de Florianópolis. Dissertação (Mestrado) Programa de Pós-Graduação em Engenharia de Produção. Universidade Federal de Santa Catarina, Florianópolis, SC. 2001. 
VIANNA, N.S.; GONÇALVES, J.S. Iluminação e Arquitetura. São Paulo, SP. Virtus s/c Ltda. 2001.

VIANA, T. S.; ZOMER, C. D.; NASCIMENTO, L.; RÜTHER, R. Centro de Eventos da UFSC: Integração de Sistemas Fotovoltaicos à Arquitetura. in: IX encontro nacional e V latino americano de conforto no ambiente construído. Ouro Preto. Anais... Ouro Preto: ANTAC. 2007.

XAVIER, A.A. Predição de Conforto Térmico em ambientes internos com atividades sedentárias: Teoria física aliada a estudos de campo. Tese (Doutorado) Programa de Pós-Graduação em Engenharia de Produção e Sistemas, Universidade Federal de Santa Catarina. Florianópolis, SC. 2000.

ZWANZIGER, M. G. et al. Tecnologia e economia do ciclo do hidrogênio Relatório Interno. Laboratório de Hidrogênio - Unicamp, Campinas, 1980.

ZILLES, R. Geração de eletricidade a partir da energia solar: sistemas fotovoltaicos. Dossiê Energia GREENPEACE. 2004.

Aplicações e Regulamentação: sistemas fotovoltaicos domiciliares, mini redes e sistemas interligados. II Simpósio nacional de energia solar fotovoltaica. CRESESB. Disponível e 2007. m: <http://www.cresesb.cepel.br/snesf/palestras/18-052005/ZILLES.pdf> Acesso em: 20 dez. 2010.

Geração distribuída com sistemas fotovoltaicos. $1^{\text {a }}$ Reunião do Grupo de Trabalho GT-GDSF. 15 de dezembro de 2008.

ZUMARÁN, D. R. O. Avaliação econômica da geração de energia elétrica fotovoltaica conectada à rede em mercados elétricos desregulados. Dissertação (Mestrado) PIPGE - EP/IEE/IF/FEA - USP, 2000. 


\section{AnEXOS}

\subsection{GABELA COMPLEGA DOS CUSGOS POR DEMANDA G POĜ́nCIA}

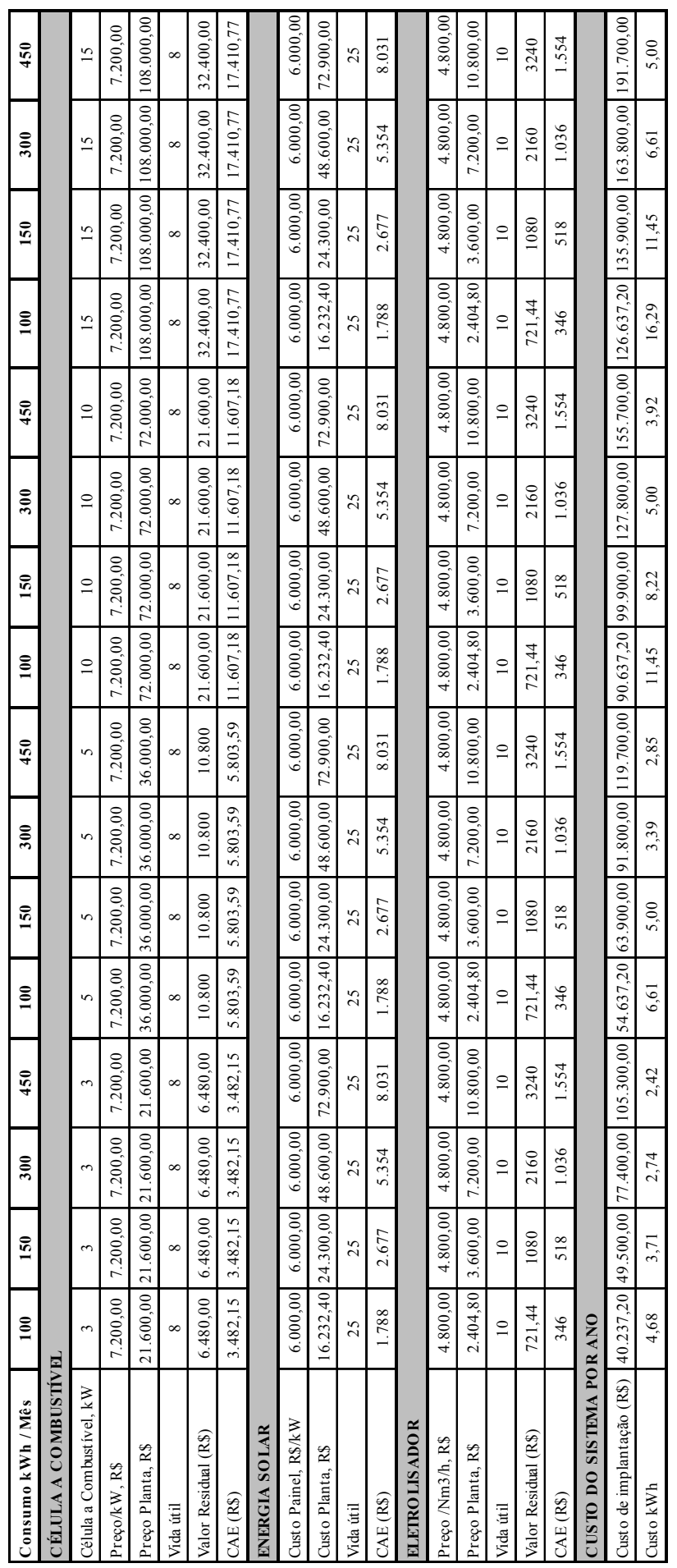


7.2. GABELA DAS ÁREAS OCUPADAS (PV) PORDECANDA $G$ POGẾCIA 
em residências

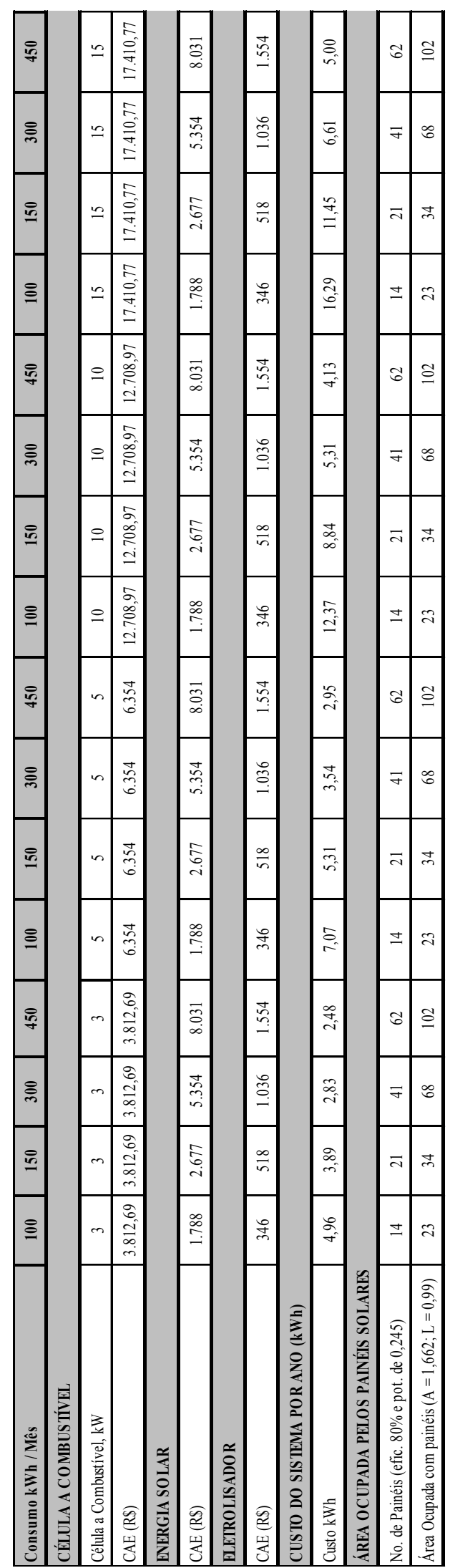


7.3. GABELA DO $\mathrm{n}^{\circ}$ DE CILINDROS DE $\bar{h}_{2}$ POR DECANDA $\epsilon$ POG ÊnCIA

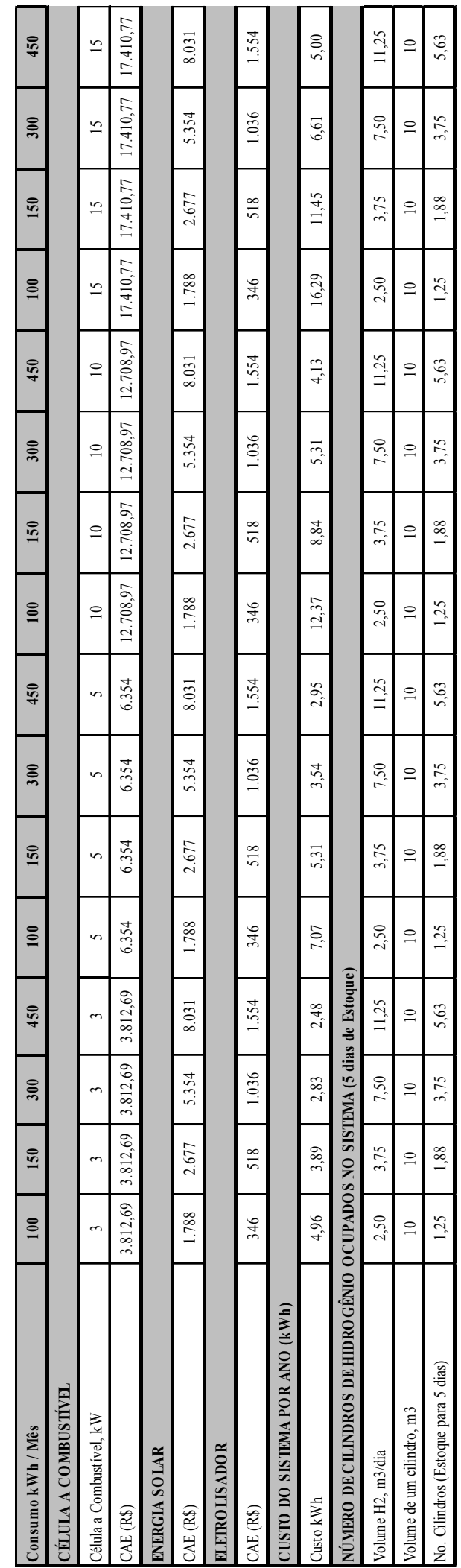




\subsection{GABELA DAS ÁREASS OCUPADAAS PORPOGẾnCIA ФÁXICA}

\begin{tabular}{|l|c|c|c|c|}
\hline CÉLULA A COMB US TÍVEL \\
\hline Célula a Combustível, kW & 3 & 5 & 10 & 15 \\
\hline ÁREA OC UPADA PELO S PAINÉIS SOLARES & & \\
\hline No. de Painéis (efic. 80\% e pot. de 0,245) & 298 & 496 & 992 & 1488 \\
\hline Área Ocupada com painéis (A =1,662; L =0,99) & 490 & 816 & 1632 & 2448 \\
\hline
\end{tabular}

\subsection{GABELA DO $\mathrm{n}^{\circ}$ DE CILINDROS PORPOGÊACIA DÁXIOA}

\begin{tabular}{|c|c|c|c|c|}
\hline \multicolumn{5}{|l|}{ CÉLULA A COMBUS TÍVEL } \\
\hline Célula a Combustível, kW & 3 & 5 & 10 & 15 \\
\hline Preço/kW, R\$ & $7.200,00$ & $3.000,00$ & $7.200,00$ & $7.200,00$ \\
\hline Preço Planta, $\mathrm{R} \$$ & $21.600,00$ & $15.000,00$ & $72.000,00$ & $108.000,00$ \\
\hline Vida útil & 8 & 8 & 8 & 8 \\
\hline Valor Residual (R\$) & $6.480,00$ & 10.800 & $21.600,00$ & $32.400,00$ \\
\hline $\mathrm{CAE}(\mathrm{R} \$)$ & $3.482,15$ & 5.804 & $11.607,18$ & $17.410,77$ \\
\hline \multicolumn{5}{|l|}{ ENERGIA SO LAR } \\
\hline Custo Painel, R\$/kW & 6000 & 6000 & 6000 & 6000 \\
\hline Custo Planta, R\$ & $349.920,00$ & $583.200,00$ & $1.166 .400,00$ & $1.749 .600,00$ \\
\hline Vida útil & 25 & 25 & 25 & 25 \\
\hline $\mathrm{CAE}(\mathrm{R} \$)$ & 38.550 & 64.250 & 128.500 & 192.750 \\
\hline \multicolumn{5}{|l|}{ ELETRO LIS ADO R } \\
\hline Preço /Nm3/h, R\$ & $4.800,00$ & $4.800,00$ & $4.800,00$ & $4.800,00$ \\
\hline Preço Planta, R\$ & $2.404,80$ & $2.404,80$ & $2.404,80$ & $2.404,80$ \\
\hline Vida útil & 10 & 10 & 10 & 10 \\
\hline Valor Residual (R\$) & 721,44 & 721,44 & 721,44 & 721,44 \\
\hline CAE (R\$) & 346 & 346 & 346 & 346 \\
\hline \multicolumn{5}{|c|}{ CUSTO DO SISTEMA POR ANO (kWh) } \\
\hline Custo de implantação (R\$) & $40.237,20$ & $54.637,20$ & $90.637,20$ & $126.637,20$ \\
\hline Custo kWh & 4,96 & 7,07 & 12,37 & 16,29 \\
\hline \multicolumn{5}{|c|}{ NÚMERO DE C ILINDROS DE HIDRO GÊNIO O CUPADOS NO SISTEMA (5 dias de Estoque) } \\
\hline Volume $\mathrm{H} 2, \mathrm{~m} 3 / \mathrm{dia}$ & 54,00 & 90,00 & 180,00 & 270,00 \\
\hline Volume de um cilindro, $\mathrm{m} 3$ & 10 & 10 & 10 & 10 \\
\hline No. Cilindros (Estoque para 5 dias) & 27,00 & 45,00 & 90,00 & 135,00 \\
\hline
\end{tabular}


7.6. GABELA DOS CUSGOS DOS COMPONENGES PELA DECANDA 


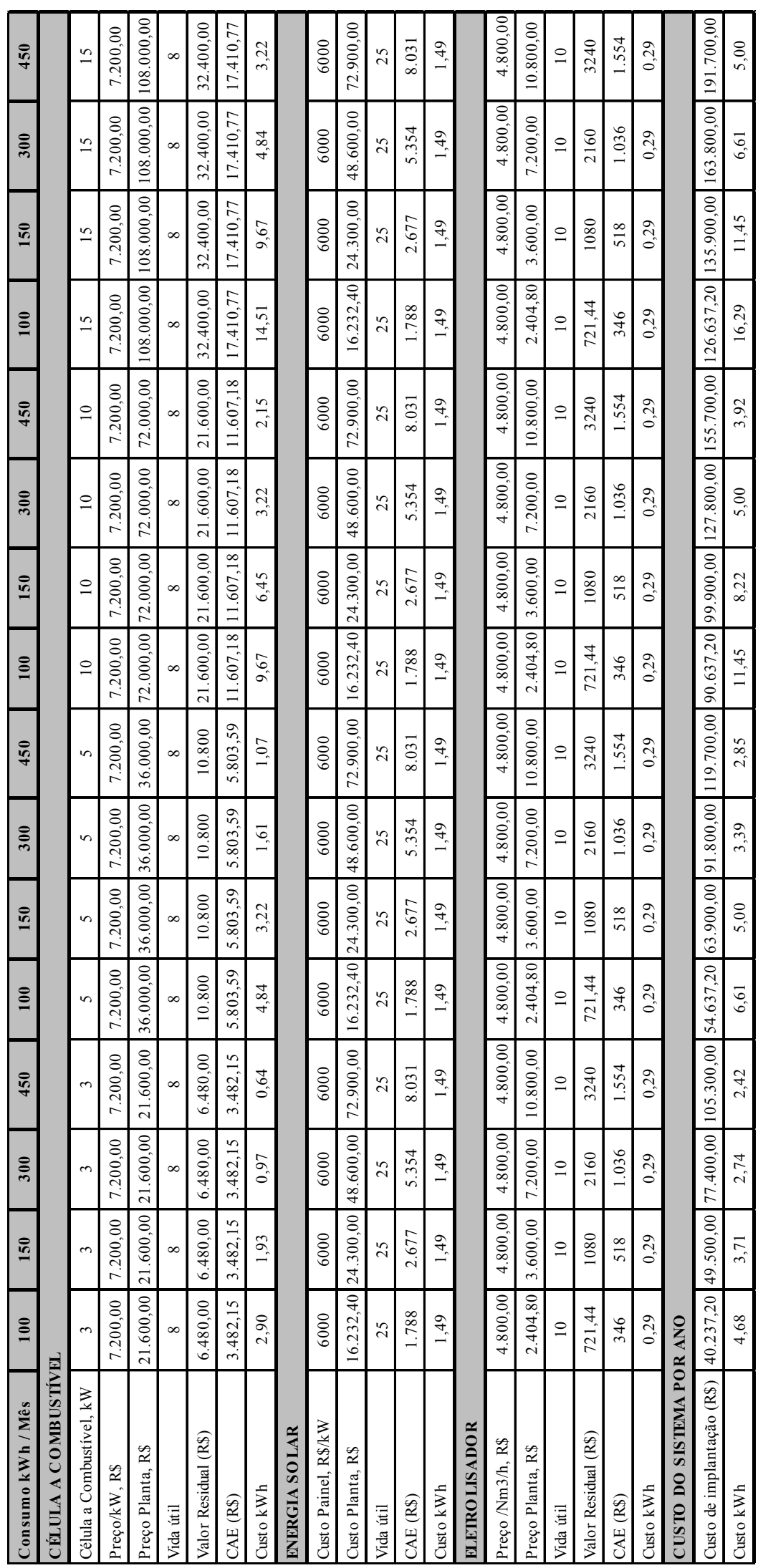




\subsection{GABELA DOS CUSGOS DOS COMPONENGES PELA POGÊECIÄ ФÁXIOA}

\begin{tabular}{|c|c|c|c|c|}
\hline \multicolumn{5}{|l|}{ C ÉLULA A COMBUS TÍVEL } \\
\hline Célula a Combustível, kW & 3 & 5 & 10 & 15 \\
\hline Preço/kW, R\$ & $7.200,00$ & $7.200,00$ & $7.200,00$ & $7.200,00$ \\
\hline Preço Planta, R\$ & $21.600,00$ & $36.000,00$ & $72.000,00$ & $108.000,00$ \\
\hline Vida útil & 8 & 8 & 8 & 8 \\
\hline Valor Residual (R\$) & $6.480,00$ & 10.800 & $21.600,00$ & $32.400,00$ \\
\hline $\mathrm{CAE}(\mathrm{R} \$)$ & $3.482,15$ & $5.803,59$ & $11.607,18$ & $17.410,77$ \\
\hline Custo kWh & 0,13 & 0,13 & 0,13 & 0,13 \\
\hline \multicolumn{5}{|l|}{ ENERGIA SOLAR } \\
\hline Custo Painel, R\$/kW & 6000 & 6000 & 6000 & 6000 \\
\hline Custo Planta, R\$ & $349.920,00$ & $583.200,00$ & $1.166 .400,00$ & $1.749 .600,00$ \\
\hline Vida útil & 25 & 25 & 25 & 25 \\
\hline $\mathrm{CAE}(\mathrm{R} \$)$ & 38.550 & 64.250 & 128.500 & 192.750 \\
\hline Custo kWh & 1,49 & 1,49 & 1,49 & 1,49 \\
\hline \multicolumn{5}{|l|}{ ELETRO LISADO R } \\
\hline Preço $/ \mathrm{Nm} 3 / \mathrm{h}, \mathrm{R} \$$ & $4.800,00$ & $4.800,00$ & $4.800,00$ & $4.800,00$ \\
\hline Preço Planta, R\$ & $51.840,00$ & $86.400,00$ & $172.800,00$ & $259.200,00$ \\
\hline Vida útil & 10 & 10 & 10 & 10 \\
\hline Valor Residual (R\$) & 15552 & 25920 & 51840 & 77760 \\
\hline $\mathrm{CAE}(\mathrm{R} \$)$ & 7.461 & 12.435 & 24.870 & 37.305 \\
\hline Custo kWh & 0,29 & 0,29 & 0,29 & 0,29 \\
\hline \multicolumn{5}{|c|}{ CUSTO DO SIS TEMA POR ANO } \\
\hline Produção Energia Mensal, kWh & 2.160 & 3.600 & 7.200 & 10.800 \\
\hline Custo de implantação (R\$) & $40.237,20$ & $54.637,20$ & $90.637,20$ & $126.637,20$ \\
\hline Custo kWh & 1,91 & 1,91 & 1,91 & 1,91 \\
\hline
\end{tabular}




\subsection{GABELA DE CÁLCULOS PARA UOA COOUNIDADE DE 40 CÄSAS}

\begin{tabular}{|c|c|c|c|c|}
\hline Consumo kWh / Mês (40 casas) & 4000 & 6000 & 12000 & 18000 \\
\hline \multicolumn{5}{|l|}{ CÉLULA A CO MBUS TÍVEL } \\
\hline Célula a Combustível, $\mathrm{kW}$ & 40 & 40 & 40 & 40 \\
\hline Preço/kW, R\$ & $7.200,00$ & $7.200,00$ & $7.200,00$ & $7.200,00$ \\
\hline Preço Planta, US\$ & $288.000,00$ & $288.000,00$ & $288.000,00$ & $288.000,00$ \\
\hline Vida útil & 8,00 & 8,00 & 8,00 & 8,00 \\
\hline Valor Residual (R\$) & $86.400,00$ & $86.400,00$ & $86.400,00$ & $86.400,00$ \\
\hline CAE (R\$) & $46.428,71$ & $46.428,71$ & $46.428,71$ & $46.428,71$ \\
\hline Custo kWh & 0,97 & 0,64 & 0,32 & 0,21 \\
\hline \multicolumn{5}{|l|}{ ENERGIA SOLAR } \\
\hline Custo Painel, R\$/kW & $6.000,00$ & $6.000,00$ & $6.000,00$ & $6.000,00$ \\
\hline Custo Planta, R\$ & $647.999,84$ & $972.000,00$ & $1.944 .000,00$ & $2.916 .000,00$ \\
\hline Vida útil & 25,00 & 25,00 & 25,00 & 25,00 \\
\hline $\mathrm{CAE}(\mathrm{R} \$)$ & $71.388,89$ & $107.083,37$ & $214.166,73$ & $321.250,10$ \\
\hline Custo kWh & 1,49 & 1,49 & 1,49 & 1,49 \\
\hline \multicolumn{5}{|l|}{ ELETRO LIS ADO R } \\
\hline Preço $/ \mathrm{Nm} 3 / \mathrm{h}, \mathrm{R} \$$ & $4.800,00$ & $4.800,00$ & $4.800,00$ & $4.800,00$ \\
\hline Preço Planta, R\$ & $95.999,98$ & $144.000,00$ & $288.000,00$ & $432.000,00$ \\
\hline Vida útil & 10,00 & 10,00 & 10,00 & 10,00 \\
\hline Valor Residual (R\$) & $28.799,99$ & $43.200,00$ & $86.400,00$ & $129.600,00$ \\
\hline CAE (R\$) & $13.816,49$ & $20.724,74$ & $41.449,47$ & $62.174,21$ \\
\hline Custo kWh & 0,29 & 0,29 & 0,29 & 0,29 \\
\hline \multicolumn{5}{|l|}{ CUSTO DO SISTEMA POR ANO } \\
\hline Custo de implantação (R\$) & $1.031 .999,81$ & $1.404 .000,00$ & $2.520 .000,00$ & $3.636 .000,00$ \\
\hline Custo kWh & 2,74 & 2,42 & 2,10 & 1,99 \\
\hline \multicolumn{5}{|c|}{ NÚMERO DE CILINDROS DE HIDRO GÊNIO OCUPADOS NO SISTEMA (5 dias de Estoque) } \\
\hline Volume $\mathrm{H} 2, \mathrm{~m} 3 /$ dia & 100,00 & 150,00 & 300,00 & 450,00 \\
\hline Volume de um cilindro, $\mathrm{m} 3$ & 10,00 & 10,00 & 10,00 & 10,00 \\
\hline No. Cilindros (Estoque para 5 dias) & 50,00 & 75,00 & 150,00 & 225,00 \\
\hline
\end{tabular}

